CAROLINA GATTOLIN DE PAULA

\title{
A ATUAÇÃO DO STF NO PÓS-88: \\ IMPACTO SOBRE O EQUILÍBRIO ENTRE OS PODERES
}

DISSERTAÇÃO DE MESTRADO

ORIENTADOR: PROFESSOR DOUTOR RUBENS BEÇAK

FACULDADE DE DIREITO DA UNIVERSIDADE DE SÃO PAULO

SÃO PAULO

2014 


\section{A ATUAÇÃO DO STF NO PÓS-88: \\ IMPACTO SOBRE O EQUILÍBRIO ENTRE OS PODERES}

Dissertação apresentada junto ao Departamento de Direito do Estado da Faculdade de Direito da Universidade de São Paulo, como exigência parcial para a obtenção do título de Mestre em Direito do Estado.

Área de concentração: Direito Constitucional.

Orientador: Professor Doutor Rubens Beçak.

\section{SÃO PAULO}


Nome: Carolina Gattolin de Paula

Título: A atuação do STF no pós-88: impacto sobre o equilíbrio entre os Poderes

Dissertação apresentada à Faculdade de Direito da Universidade de São Paulo para obtenção do título de Mestre em Direito do Estado, na área de concentração de Direito Constitucional.

Aprovado em:

Banca Examinadora

Prof. Dr. Rubens Beçak

Instituição: Universidade de São Paulo

Julgamento:

Assinatura:

Prof. Dr.

Instituição:

Julgamento:

Assinatura:

Prof. Dr. Instituição:

Julgamento: Assinatura: 
Para meus pais, Sandra e Milton, e meu irmão, Gabriel, com todo meu amor e minha admiração. 


\section{AGRADECIMENTOS}

Sempre e em tudo, agradeço primeiramente a meus pais, por me incentivarem, desde muito cedo, à busca de desafios e por todos os esforços e apoio para que eu pudesse realizálos. Agradeço por serem meu exemplo de vida e, claro, pelo amor incondicional.

Agradeço imensamente ao Professor Rubens Beçak pela oportunidade que me foi dada de completar esse grande desafio acadêmico (e pessoal) e pela oportunidade de prolongar meu convívio na Faculdade de Direito do Largo São Francisco. Agradeço pelos conselhos sempre pertinentes, pela paciência e pela confiança.

Agradeço aos amigos do escritório Tozzini Freire Advogados, pela compreensão e pelo apoio.

Ao Neto, pela cumplicidade sem fim. À Kaori, por tanto carinho.

E ao Fernando, pelo companheirismo em todos os momentos, prova que colho diariamente do acerto de minha escolha. 


\section{RESUMO}

PAULA, Carolina Gattolin de. A atuação do STF no pós-88: impacto sobre o equilíbrio entre os Poderes. 2014. 151p. Dissertação (Mestrado) - Faculdade de Direito, Universidade de São Paulo, São Paulo, 2014.

Após a promulgação da Constituição de 1988, o Supremo Tribunal Federal passou a integrar a vida cotidiana da população, por meio das diversas informações sobre seus julgamentos, os quais envolvem, cada vez mais, questões políticas, com impacto sobre a vida dos cidadãos. Essa atuação da Corte tem despertado algumas críticas, relacionadas principalmente à sua legitimidade democrática para decidir sobre assuntos políticos e a uma suposta violação do princípio da separação de Poderes. Esse debate está inserido no contexto mais amplo de protagonismo do Poder Judiciário brasileiro no século XXI, expressado principalmente pela expansão da jurisdição constitucional, o que, por sua vez, se deve à consolidação do sistema de controle de constitucionalidade e a uma "nova" interpretação constitucional. Com efeito, a Constituição de 1988 expandiu as competências do Supremo, incitando o exercício de sua função política. As críticas feitas à Corte em razão de sua atuação com relação a questões políticas estão relacionadas a dois fenômenos, a "judicialização da política" e o "ativismo judicial", sendo este considerado por parte da doutrina como uma indevida interferência do Poder Judiciário no âmbito de atuação dos Poderes Legislativo e Executivo. Casos como o reconhecimento da união estável homoafetiva foram considerados expressão desse ativismo. No entanto, é possível abordar o assunto da legitimidade democrática da Corte e da separação de Poderes de forma diferente, mais flexível. As teorias do diálogo, nessa medida, apresentam uma nova proposta de interação entre o Supremo Tribunal Federal e o Poder Legislativo, conferindo compreensão mais atual da democracia e da separação de Poderes. Isso porque prescinde da opção de predomínio do Legislativo ou do Judiciário em dar a "última palavra" sobre a constitucionalidade de leis e atos normativos. Desse modo, este trabalho visa a demonstrar, que há de se procurar saídas à rígida estrutura da Teoria da Separação de Poderes de Montesquieu, a fim de que a Constituição possa ser concretizada mediante uma efetiva colaboração dos Poderes.

Palavras-chave: Separação de Poderes. Protagonismo do Poder Judiciário. Supremo Tribunal Federal. 


\begin{abstract}
PAULA, Carolina Gattolin de. The performance of the Brazilian Supreme Court in the post88: impact on the balance of powers. 2014. 151p. Dissertação (Mestrado) - Faculdade de Direito, Universidade de São Paulo, São Paulo, 2014.

After the promulgation of the Constitution of 1988, Brazilian Supreme Court became part of everyday life of the population due to the various information about its trials, which involve, increasingly, political issues that impact the life of Brazilian population. Such performance of the Court has aroused some criticism, mainly related to its democratic legitimacy to decide on political affairs and to the violation of the principle of the separation of Powers. This debate is embedded in the broader context of the Brazilian Judiciary protagonism in the XXI Century, specially expressed by the expansion of constitutional jurisdiction, which is due to the consolidation of the judicial review system and a "new" constitutional interpretation. Indeed, Constitution of 1988 expanded the powers of the Supreme Court, urging the exercise of its political function. The criticisms addressed to the Court by reason of its performance with respect to policy issues are related to two phenomena: the "judicialization of politics" and "judicial activism", which are considered by the doctrine as an undue interference by the Judiciary on the performance of the Legislative and Executive branches. Cases such as the recognition of homo-affective union were considered stable expression of activism. However, it is possible to approach more flexibly the issue of democratic legitimacy of the Court and of the separation of powers more flexibly. Theories of dialogue present a new proposal for interaction between the Supreme Court and the legislature, giving more current understanding of democracy and separation of powers. It reveals an alternative to waive predominance of the Legislature or the Judiciary to give the "last decision" on the constitutionality of laws and normative acts. Thus, this study aims to demonstrate, there to seek outlets to the rigid structure of Montesquieu's Separation of Powers, so that the Constitution can be achieved through effective collaboration of Powers.
\end{abstract}

Keywords: Separation of Powers. Protagonism of Judiciary Power. Brazilian Supreme Court. 


\section{SUMÁRIO}

INTRODUÇÃO. .08

1. A TEORIA DA SEPARAÇÃO DE PODERES DE MONTESQUIEU E SUA EVOLUÇÃO NOS SÉCULOS XVIII A XXI.......................................................... 12

1.1. Precursores da Teoria da Separação de Poderes de Montesquieu........................ 12

1.2. A Teoria da Separação de Poderes de Montesquieu.............................................16

1.3. Separação e protagonismo dos Poderes entre os séculos XVIII e XXI................26

2. OS PODERES LEGISLATIVO E JUDICIÁRIO NA CONSTITUIÇÃO DE 1988 .50

2.1. Perspectiva histórica da separação de Poderes no Brasil....................................50

2.2. A separação de Poderes na Constituição de 1988 ...............................................58

2.3. O Poder Legislativo na separação de Poderes da Constituição de 1988............ 65

2.4. O protagonismo do Poder Judiciário: expansão da jurisdição constitucional.... 72

2.4.1. Consolidação do sistema do controle de constitucionalidade.................. 75

2.4.2. A "nova" interpretação constitucional......................................................84

3. O SUPREMO TRIBUNAL FEDERAL NO PÓS-88.............................................94

3.1. Competências do Supremo Tribunal Federal na Constituição de 1988..............94

3.2. A "judicialização da política", o "ativismo judicial” e a jurisprudência do

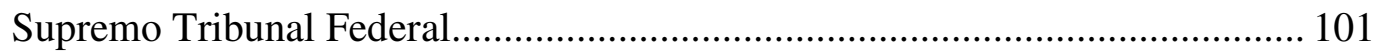

3.2.1. Críticas à expansão da interferência judicial em questões políticas..........116

3.3. Proposta da interação deliberativa entre o STF e o Congresso Nacional como expressão da separação de Poderes.....................................................................128

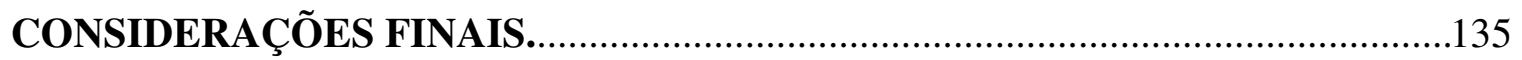

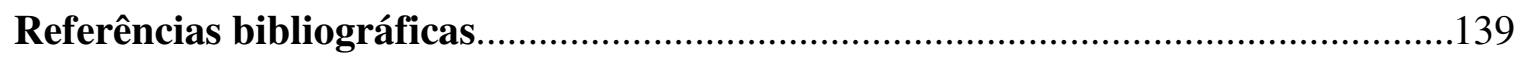




\section{INTRODUÇÃO}

Na última década, assim como as notícias sobre os campeonatos de futebol, tornou-se praticamente diária a divulgação de notícias - na grande mídia, não apenas naquela especializada -, relacionadas ao Poder Judiciário, em especial, ao Supremo Tribunal Federal. São veiculadas informações não apenas sobre o resultado de seus julgamentos, que passaram a envolver cada vez mais temas de interesse da população como um todo, mas também sobre sua estrutura e sobre seu funcionamento, com o que se promove uma aproximação e uma familiarização crescente entre a Corte e seu público.

Se, até a promulgação da Constituição de 1988, o Supremo Tribunal Federal havia passado por anos de anulação em razão da ditadura militar que lhe tolheu a independência de julgamento, a partir de 1988, a Corte passou a gozar não só de autonomia e efetiva independência, mas também de competências muito ampliadas, impulsionadas por novos mecanismos processuais que promoveram maior acesso da população à justiça e à jurisdição constitucional. Ficou evidente a ocorrência de uma explosão de litigiosidade.

Com respaldo na própria Constituição, notadamente analítica e vocacionada à ampla garantia da democracia e dos direitos fundamentais, o Supremo Tribunal Federal passou a atuar de modo mais contundente no que se refere a questões políticas. Em grande medida, isso pode ser atribuído à ineficiência dos Poderes Legislativo e Executivo na concretização das normas constitucionais e, ainda, à crescente descrença popular nos atores políticos, revelando notória crise de representatividade.

Embora a atuação do Supremo Tribunal Federal no controle de constitucionalidade de questões políticas venha trazendo alguns avanços, principalmente para o desenvolvimento da garantia dos direitos fundamentais das minorias e para a proteção do próprio sistema político e eleitoral, ela também tem provocado diversas críticas. As duas críticas mais expressivas são uma suposta ilegitimidade democrática da Corte para decidir sobre esses temas, pois seus membros não são eleitos e não representam a vontade popular, e uma suposta violação ao princípio da separação de Poderes, já que o Poder Judiciário estaria usurpando função política originariamente atribuída ao Legislativo e ao Executivo.

É esse o pano de fundo do presente trabalho, cujo objetivo final é, a partir da análise do cenário da organização dos Poderes no Brasil após a Constituição de 1988 e da inserção do 
Supremo Tribunal em tal cenário, verificar se, no desempenho de suas competências de revisão judicial, a Corte tem o condão de provocar uma nova dinâmica entre os Poderes Judiciário e Legislativo, tendo em vista a evidente insuficiência da Teoria de Separação de Poderes de Montesquieu para sustentar a complexidade funcional dos Estados contemporâneos.

Com esse objetivo, dado ser a separação de Poderes tema central do trabalho, este reserva o primeiro capítulo à apresentação da teoria montesquiana de separação de Poderes, utilizada até os dias atuais como principal parâmetro de organização dos Poderes nos Estados de Direito. Destaca-se, ainda, a evolução da aplicação dessa teoria no decorrer dos séculos que se seguem à Revolução Francesa de 1789, mostrando especialmente a relação entre a separação de Poderes e o desenvolvimento do Estado, a partir do Estado Liberal até o Estado Democrático de Direito.

Nesse primeiro capítulo, procura-se argumentar que as teorias de separação de Poderes devem-se adaptar às circunstâncias de determinado momento histórico e às peculiaridades do Estado, razão por que a Teoria da Separação de Poderes de Montesquieu, pensada para o Estado Liberal do século XIX, hoje, é insuficiente para prever todas as interações possíveis entre os Poderes no Estado Democrático de Direito.

Por fim, procura-se explicar as razões pelas quais, desde a primeira aplicação da Teoria da Separação de Poderes de Montesquieu, na França revolucionária, não se estabeleceu exatamente um equilíbrio entre os Poderes, tendo o Legislativo se destacado entre os demais. Constata-se que essa situação se verificou, ainda, no Estado Social, em que se pode dizer que houve prevalência do Poder Executivo e, hoje, no Estado Democrático de Direito, em que se verifica o protagonismo do Poder Judiciário.

A partir dos argumentos apresentados no capítulo inicial do trabalho, de que 1) a teoria de Montesquieu é insuficiente para a organização de Poderes no Estado contemporâneo, devido à multiplicidade de funções estatais e à necessidade de distribuição mais complexa e fluida dessas funções; e 2) o Poder Judiciário tem desempenhado papel de destaque dentre os demais no século XXI, passamos ao segundo capítulo.

No segundo capítulo, pretende-se a exposição, com mais detalhes, sobre as causas do protagonismo do Poder Judiciário no Brasil, partindo-se da análise da prática da separação de Poderes em face da realidade política e social brasileira após a promulgação da Constituição de 1988, bem como dos fatores que determinaram a expansão da jurisdição constitucional, 
seja em razão de modificações diretamente relacionadas ao Judiciário, como a consolidação do controle de constitucionalidade e o advento de uma "nova" interpretação constitucional, seja por fatores externos, como a falha na atuação dos atores políticos, sempre com destaque para o Poder Legislativo.

Esclareça-se, desde já, que a opção de cotejar, com maior grau de detalhamento, o papel do Judiciário com o papel do Legislativo deve-se não apenas à necessária delimitação metodológica, mas também ao fato de que o ponto culminante da análise sobre o papel do Supremo Tribunal Federal no atual cenário de separação de Poderes, verificada ao final do terceiro capítulo, baseia-se no estudo da teoria do diálogo deliberativo como influxo para uma nova separação de Poderes, de acordo com a proposta de Conrado Hübner Mendes. Este autor, por sua vez, expressamente exclui o Poder Executivo de tal análise. ${ }^{1}$

Finda a análise dos fatores internos e externos que impulsionaram o protagonismo do Poder Judiciário no Brasil, sobretudo sob o aspecto da justiça constitucional, após a promulgação da Constituição de 1988, segue-se o terceiro capítulo, em que se pretende demonstrar a ampliação das competências do Supremo Tribunal Federal, especialmente no que toca à sua função política.

Nesse sentido, pretende-se verificar a expandida função política do Supremo Tribunal Federal à luz de duas questões que suscitam grandes debates jurídicos e, obviamente, políticos, a "judicialização da política" e o "ativismo judicial”, relacionando-os com a recente jurisprudência da Corte.

Ademais, como mencionado anteriormente, passa-se a apresentar algumas críticas dirigidas ao Supremo Tribunal Federal (e, em certa medida, aos juízes e Tribunais), conferindo importância maior a duas "acusações". A primeira, de que a Corte não teria legitimidade democrática para rever decisões tomadas pelos atores políticos, sobretudo em questões políticas - a saber, que envolvam basicamente a discussão sobre separação de Poderes, reconhecimento de direitos fundamentais, federalismo e controle do funcionamento das instituições democráticas. A segunda, especialmente relacionada à questão do ativismo judicial, de que a interferência do Supremo Tribunal Federal em tais matérias por meio do

\footnotetext{
1 "Uma abordagem integral da separação de poderes através da "perspectiva dialógica" requereria também a análise de como o Executivo participa nesse processo. Este trabalho, porém, concentra-se numa versão incompleta de uma teoria mais ampla. Esse foco restrito à relação entre o parlamentos e cortes é a opção tradicional da teoria constitucional e tem uma razão de ser: o Poder Executivo nunca foi considerado como um candidato para a última palavra em questão de direitos fundamentais." MENDES, Conrado Hübner. Direito fundamentais, separação de poderes e deliberação. São Paulo: Saraiva, 2011, p. 105.
} 
controle de constitucionalidade configuraria uma usurpação das funções dos demais Poderes, em violação à separação de Poderes.

Sem a pretensão de oferecer todas as respostas possíveis a essas críticas, mas usandoas como forma de demonstrar a reacomodação dos Poderes em vista da atuação incisiva do Supremo Tribunal, optamos por encerrar o capítulo apresentando uma opção de compreensão da separação de Poderes que visa a uma terceira via, que prescinda da opção de predomínio do Legislativo ou do Judiciário em dar a última palavra sobre a constitucionalidade de leis e atos normativos.

Apresentamos, assim, segundo proposta de Conrado Hübner Mendes, a opção pelo diálogo deliberativo entre a Judiciário e Legislativo, constatando que a melhor opção para a manutenção do equilíbrio da democracia e da organização dos Poderes seria a do estabelecimento de uma interação construtiva entre o Supremo Tribunal Federal e o Congresso Nacional, o que já se pôde constatar em alguns casos envolvendo as duas instituições.

Em síntese, a ideia deste trabalho é demonstrar, por meio das discussões referidas acima, que há de se procurar saídas mais flexíveis à rígida estrutura da Teoria da Separação de Poderes de Montesquieu, a fim de que a Constituição possa ser concretizada mediante uma efetiva colaboração dos Poderes, contando com o suporte do Supremo Tribunal Federal, mas não relegando a ele responsabilidade de tarefa que incumbe a todo o Estado. 


\section{EVOLUÇÃO DA TEORIA DA SEPARAÇÃO DE PODERES DE MONTESQUIEU}

\subsection{Precursores da Teoria da Separação de Poderes de Montesquieu}

Para dar início à discussão sobre o impacto do Supremo Tribunal Federal sobre o equilíbrio entre os Poderes estatais, especialmente sobre a relação entre os Poderes Judiciário e Legislativo a partir de 1988 no Brasil, não se pode prescindir de estudo, ainda que breve, sobre a organização dos Poderes no Estado contemporâneo e evolução dessa organização, tendo como marco inicial a clássica Teoria de Separação elaborada pelo Barão de Montesquieu no contexto da queda do Estado Absolutista.

A partir dessa análise será possível identificar a configuração da separação de Poderes ao longo dos séculos, a partir das Revoluções Liberais e as razões para a predominância de um ou de outro Poder em determinados momentos históricos. Objetiva-se demonstrar que, no século XXI, o Poder Judiciário vem desempenhando papel de destaque em relação ao Legislativo e ao Executivo no Estado Democrático de Direito brasileiro, principalmente no que se refere à jurisdição constitucional.

A escolha da teoria montesquiana como ponto inicial de estudo sobre a separação de poderes é bastante corrente na doutrina pátria e estrangeira, tendo em vista o amplo reconhecimento de que, somente com o advento dessa teoria, pôde-se falar em efetiva sistematização da separação dos poderes. Sobretudo, reconhece-se que o grande trunfo dessa teoria, respaldada na efervescência política das Revoluções Liberais, foi a sua elevação a postulado indispensável à ideia de democracia, tendo em vista a exaltação à garantia da liberdade individual em relação ao Estado por meio da atribuição das funções legislativa, executiva e judiciária a diferentes órgãos estatais.

Não se olvida que, antes de Montesquieu, mesmo que de forma assistemática, houve preocupação com a organização e com o exercício do poder. 
Segundo Norberto Bobbio, ${ }^{2}$ apesar de demonstrações anteriores, ${ }^{3}$ pode-se dizer que a preocupação com a organização do poder estatal remonta à Antiguidade, especialmente a partir da enunciação, por Aristóteles, de sua notória classificação das formas de governos, baseada no número de detentores do poder e no interesse que move a atuação dos governantes, donde concluiu que a melhor forma de governo é a "mista". ${ }^{4}$ Isso porque só por meio da forma de governo mista é que seria possível estabelecer um equilíbrio no Poder político, mediante a incorporação das diversas classes sociais em correspondentes instituições governamentais.

Mesmo que de forma insipiente no que se refere à efetiva separação de poderes, Aristóteles já prenunciava a injustiça e perigo na atribuição do exercício do poder a um só indivíduo e já identificava três funções diferentes no exercício do poder estatal, funções estas que denominou poderes. Seriam esses poderes os seguintes: o poder que delibera sobre negócios do Estado; o poder que compreende todas as magistraturas ou poderes constituídos (aqueles de que o Estado tem necessidade para agir), as suas atribuições e a maneira de realizá-las; e o poder que abrange as tarefas de jurisdição. ${ }^{5}$

Não obstante, Aristóteles não demonstrou preocupação com a repartição orgânica das funções estatais, aceitando que elas pudessem ser exercidas pela mesma pessoa ou órgão, o que viria a ser absolutamente rechaçado na teoria da separação de poderes de Montesquieu.

Ainda com relação à Antiguidade, Rubens Beçak destaca a importância dos estudos de Políbio e de Cícero, especialmente no que diz respeito ao elogio dos pensadores à forma mista de governo praticada em Roma. Isso porque, nessa forma de governo, já era possível identificar a atribuição de diferentes funções a cada um dos estratos da sociedade romana (a realeza, a aristocracia e a plebe). ${ }^{6}$

\footnotetext{
${ }^{2}$ BOBBIO, Norberto. A teoria das formas de governo. Tradução de Sérgio Bath. 10. ed. Brasília: UnB, 1998, p. 55.

${ }^{3}$ A título de exemplo, ressalta-se que Heródoto, em sua obra História (Livro III, §§ 80-82), no século V a.C., já propusera a discussão sobre as formas de governo, distinguindo três modalidades: o governo de muitos ("democracia"), de poucos ("aristocracia") e de um só ("monarquia").

${ }^{4}$ Em síntese, as formas de governo, segundo Aristóteles, seriam a (i) monarquia (governo de um no interesse geral); a (ii) aristocracia (governo de poucos no interesse geral); e a (iii) politeia (governo de muitos no interesse geral). O desvirtuamento de cada uma dessas formas de governo, consideradas puras, daria origem às suas versões impuras, respectivamente, a (i) tirania (governo de um no interesse pessoal); a (ii) oligarquia (governo de poucos no próprio interesse); e a (iii) democracia (governo de muitos no próprio interesse). Cf. ARISTÓTELES. A Política. Tradução de Roberto Leal Ferreira. 3. ed. São Paulo: Martins Fontes, 2006.

${ }^{5}$ ARISTÓTELES. A Política. Tradução de Roberto Leal Ferreira. 3. ed. São Paulo: Martins Fontes, 2006, p. 113.

${ }^{6}$ BEÇAK, Rubens. A hipertrofia do Executivo brasileiro: impacto da Constituição de 1988. 2005. 184 p. Tese (Doutorado) - Faculdade de Direito, Universidade de São Paulo, São Paulo, 2005, p. 27.
} 
No período entre a Antiguidade e a Idade Moderna, pouco se discutiu sobre a concepção do Estado e a tipologia dos regimes de governo, ${ }^{7}$ vindo essas questões tornarem-se alvo de preocupação a partir das concepções de soberania de Maquiavel $^{8}$ e Bodin. $^{9}$

A partir do início do século XVII, na Inglaterra, o debate sobre a organização do poder estatal ganha destaque e começa a se consolidar, tendo como origem remota a Carta Magna de 1215, imposta ao Rei João Sem Terra, visando à garantia de direitos civis aos barões ingleses e à Igreja. Essa Carta se tratou da primeira tentativa de limitação do poder real e, apesar de repudiada pelos Reis ingleses seguintes, teve especial relevância na Inglaterra do século XVII, quando recrudesceram as relações entre o Rei e o Parlamento, que culminou na Revolução Gloriosa de 1688.

Com efeito, resultou da Revolução Gloriosa de 1688 o Bill of Rights, carta de declaração de direitos que viabilizou ao Parlamento a conquista definitiva da função deliberativa legislativa, primeira função política a sair das mãos do Rei e passar ao órgão coletivo autônomo de representação da sociedade.

A partir de então, a organização da esfera pública inglesa passou a ter dois poderes, ou seja, dois órgãos distintos exercendo funções estatais distintas: o Poder Legislativo (Parlamento) praticando a função deliberativa legislativa e o Poder Executivo (em sentido lato) praticando suas funções remanescentes (a de última instância, a de administrar, a de governar e a de julgar). ${ }^{10}$

O inglês John Locke foi o grande teórico da separação de poderes advinda da Revolução Gloriosa, apontando a existência de quatro funções fundamentais, exercidas por

\footnotetext{
${ }^{7}$ Conforme Rubens Beçak, deste período, cabe fazer referência a Santo Tomás de Aquino, Isidoro de Sevilha, Bártolo, Marcílio de Pádua e, quase adentrando a Idade Moderna, Coluccio Salutati. (BEÇAK, Rubens. A hipertrofia do Executivo brasileiro: impacto da Constituição de 1988. 2005. 184 p. Tese (Doutorado) Faculdade de Direito, Universidade de São Paulo, São Paulo, 2005, p. 28.)

${ }^{8}$ Cf. MAQUIAVELLI, Niccolò. O príncipe: com as notas de Napoleão Bonaparte. 5 ed. Tradução de José Cretella Junior e Agnes Cretella. São Paulo: Revista dos Tribunais, 2009. Em exame da teoria de Maquiavel, Dalmo de Abreu Dallari esclarece: "Segundo informação contida em "O Príncipe", de Maquiavel, no começo do século XVI, já se encontravam na França três poderes distintos: o legislativo (Parlamento), o executivo (o rei) e um judiciário independente. É curioso notar que Maquiavel louva essa organização porque dava mais liberdade e segurança ao rei. Agindo em nome próprio, o judiciário poderia proteger os mais fracos, vítimas de ambições e das insolências dos poderosos, poupando o rei da necessidade de interferir nas disputas e de, em consequência, enfrentar o desagrado dos que não tivessem suas razões acolhidas." (DALLARI, Dalmo de Abreu. Elementos de teoria geral do Estado. 32. ed. São Paulo: Saraiva, 2013, p. 183.)

${ }^{9}$ Em 1576, Jean Bodin (1529-1596) publica, em Paris, os Seis Livros da República, em que teoriza sobre o poder absoluto soberano (o rei), o qual seria perpétuo e absoluto, e define o Estado soberano, reconhecendo três tipos de comunidade: monarquia, aristocracia e democracia, conforme o poder fosse atribuído a um indivíduo, a uma minoria, ou a uma maioria. Cf. BODIN, Jean. Os seis livros da República: livro primeiro. Traduzido por José Ignácio Coelho Mendes Neto. São Paulo: Editora Ícone, 2011. (Coleção Fundamentos do Direito)

${ }_{10}$ SOUZA JUNIOR, Cezar Saldanha. O tribunal constitucional como poder: uma nova teoria da divisão dos poderes. São Paulo: Memória Jurídica, 2002, p. 44-46.
} 
dois órgãos do poder. Caberia ao Parlamento a função de elaborar as leis e de determinar o modo como há de ser empregada a força contra a comunidade para proteção de si mesma e de seus membros. Por sua vez, caberia ao Rei, subordinado ao Parlamento, (i) a função executiva, entendida como o exercício da aplicação das leis vigentes, (ii) a função federativa, consistente no manejo da política e das relações internacionais (declarar a guerra e a paz, constituir ou desconstituir alianças), e (iii) a função prerrogativa, esta significando a função de agir discricionariamente, sempre em favor do bem público, quando surgirem questões para as quais a lei não tenha previsto soluções ou até mesmo agir contra a lei. ${ }^{11}$

Não obstante, apesar de Locke ter sido o primeiro a efetivamente advertir para a utilidade de uma separação de poderes, não logrou desenvolver uma teoria suficientemente clara e precisa. Isso porque, embora recomende, em certa medida, a separação dos Poderes Legislativo e Executivo entre diferentes órgãos, tratando-os como Poderes independentes entre si, não chega a defender a absoluta separação deles em distintos órgãos. Dalmo de Abreu Dallari bem destaca que Locke recomendou o exercício de poder discricionário pelo Rei ao lhe conferir a prerrogativa, ou seja, Locke não atentou para a circunstância de que o bem público, impossível de ser claramente definido, sempre seria um bom pretexto para as decisões absolutistas. ${ }^{12}$

Por isso mesmo, Raymond Carré de Malberg conclui que, na realidade, a doutrina de Locke se resume a uma simples teoria de distinção das funções estatais, mas não de verdadeira separação dos poderes: "bajo la reserva de que el rey por sí solo no puede hacer la ley y que se halla sometido a esta última, no es aún uma doctrina de franca separación de lós poderes.". 13

Após o momento inicial de experiência da bipartição dos poderes, também foi inglesa a primeira experiência prática de tripartição de Poderes já no início do século XVIII, somando-se aos Poderes Legislativo e Executivo, o Poder Judiciário (agora desvinculado do Executivo). O nascimento do Judiciário como poder independente na Inglaterra ocorreu com a edição do Ato de Estabelecimento, aprovado pelo Parlamento em 12 de junho de 1701, que explicitamente determinava que a manutenção dos magistrados em seus cargos dependeria

\footnotetext{
${ }^{11}$ LOCKE, John. Segundo tratado sobre o governo. Tradução de E. Jaci Monteiro. São Paulo: Ibrasa, 1963. Conferir, especialmente, os capítulos XII, XIII e XIV.

${ }^{12}$ DALLARI, Dalmo de Abreu. Elementos de teoria geral do Estado. 32. ed. São Paulo: Saraiva, 2013, p. 183.

${ }^{13}$ MALBERG, Raymond Carré de. Teoría general del Estado. Traducción de José Lión Depetre. México: Fondo de Cultura Económica, 1948, p. 742.
} 
não mais do beneplácito real, mas da demonstração de zelo no cumprimento de seus deveres funcionais. $^{14}$

Todavia, a despeito da experiência prática inglesa, é apenas com a elaboração da teoria do Barão de Montesquieu que se pode falar em verdadeira fórmula de tripartição de poderes.

Ao contrário do que se teorizara até o momento, Montesquieu se preocupou especialmente em sistematizar as diferentes funções estatais, atribuindo-as a órgãos estatais distintos, defendendo a ideia de que Poderes limitados originariam um governo moderado. Sua teoria, portanto, trata-se francamente de uma teoria precisa de separação orgânica de poderes, destacada, sobretudo, pelo fato de ser enunciada como um princípio geral, ou seja, como uma das condições fundamentais da devida organização dos poderes de um Estado.

De fato, as análises sobre separação de poderes que precederam à de Montesquieu refletiam unicamente a experiência empírica dos teóricos, como a própria teoria de Locke (um dos expoentes do movimento empirista), que revela a organização que se verificou no Estado inglês imediatamente após a Revolução de 1688. Montesquieu, por sua vez, embora tenha criado sua teoria a partir da observação e estudo das instituições do Estado inglês no período entre 1729 e 1731, possui a vantagem de ter desenvolvido uma teoria genérica, aplicável a um Estado ideal, ou seja, a qualquer Estado.

Nessa medida, pondera Cezar Saldanha Junior que, quando chega a vez da França e dos demais países continentais adentrarem a Era Liberal, na última década do século XVIII, “já encontram pronta e testada a experiência da tripartição dos poderes, cozinhada lentamente na História Inglesa.". 15

\subsection{Teoria da Separação de Poderes de Montesquieu}

A partir da experiência tripartite inglesa e no contexto das Revoluções Liberais pela redefinição do papel do soberano, o Barão de Montesquieu desenvolveu, em sua clássica obra

\footnotetext{
${ }^{14}$ SALDANHA JUNIOR, Cezar. $O$ tribunal constitucional como poder: uma nova teoria da divisão dos poderes. São Paulo: Memória Jurídica, 2002, p. 53.

${ }^{15}$ SALDANHA JUNIOR, Cezar. O tribunal constitucional como poder: uma nova teoria da divisão dos poderes. São Paulo: Memória Jurídica, 2002, p. 48.
} 
Do espírito das leis, ${ }^{16}$ a teoria de separação de poderes que serviu de paradigma para a organização estatal dos Estados Constitucionais ocidentais contemporâneos, conferindo efetiva densidade ao tema.

Apesar da divergência doutrinária a respeito da originalidade do modelo proposto por Montesquieu, ${ }^{17}$ como bem sintetiza Rubens Beçak, ${ }^{18}$ parece evidente que o filósofo francês, influenciado direta ou indiretamente por seus precursores, sobretudo Locke, trilhou o caminho de estabelecer, concretamente, experiências de funcionamento político de realidades observadas no exterior (especialmente na Inglaterra) ou fórmulas oportunas para limitar o poder.

Nessa medida, Paulo Bonavides destaca o distanciamento entre as obras de Locke e de Montesquieu, pois Locke não conseguiu triunfar plenamente no que se refere ao "cerceamento do poder estatal". Em Locke, "o poder se limita pelo consentimento, pelo direito natural, pela virtude dos governantes, de maneira mais ou menos utópica", ao passo que, em Montesquieu, em razão de sua técnica de organização, a limitação do poder é menos abstrata. ${ }^{19}$

No célebre Capítulo VI ("Da constituição da Inglaterra”) de sua obra, ${ }^{20}$ Montesquieu apresenta as linhas mestras de sua teoria, que pode ser resumida na seguinte fórmula: (i) divisão do poder estatal entre os três órgãos existentes (Rei, Parlamento e Juízes), (ii) atribuição a cada órgão de uma das três funções em que se poderia classificar a política (executiva, legislativa e judicial), da forma mais separada e pura possível, e (iii)

\footnotetext{
${ }^{16}$ MONTESQUIEU, Charles-Louis de Secondat, Barão de La Brède e de. Do espírito das leis. Tradução de Fernando Henrique Cardoso e Leôncio Martins Rodrigues. São Paulo: Abril Cultural, 1979. (Os Pensadores.)

17 A doutrina apresenta divergência a respeito da originalidade da teoria da separação de poderes de Montesquieu. Há os que consideram ser Locke o autor original da teoria da separação de poderes (cf. CAETANO, Marcello. Manual de ciência política e direito constitucional. t. I. 6. ed. Coimbra: Almedina, 2006, p. 192-194); outros entendem que Montesquieu desenvolveu apenas uma "síntese sincrética" das teorias formuladas anteriormente (PIÇARRA, Nuno. A separação dos poderes como doutrina e princípio constitucional: um contributo para o estudo das suas origens e evolução. Coimbra: Coimbra Editora, 1989, p. 20). De outra parte, numerosa doutrina atribui real especialidade à teoria montesquiana, diferenciando-a das demais por ter sido a única a prever efetiva separação entre as funções estatais (Executivo, Legislativo e Judiciário). Nesse sentido, cf. MALBERG, Raymond Carré de. Teoría general del Estado. Traducción de José Lión Depetre. México: Fondo de Cultura Económica, 1948, p. 745. Na doutrina nacional, que tende em grande parte a reconhecer a primazia de Montesquieu, cf. FERREIRA FILHO, Manoel Gonçalves. Do processo legislativo. 7. ed. São Paulo: Saraiva, 2012, p. 59-60.; BASTOS, Celso Seixas Ribeiro. Curso de direito constitucional. 22. ed. São Paulo: Malheiros, 2010, p. 351 e ss., TAVARES, André Ramos. Curso de direito constitucional. 11. ed. São Paulo: Saraiva, 2013, p. 859.

${ }^{18}$ BEÇAK, Rubens. A hipertrofia do Executivo brasileiro: impacto da Constituição de 1988. 2005. 184 p. Tese (Doutorado) - Faculdade de Direito, Universidade de São Paulo, São Paulo, 2005, p. 29-30. Destaque-se o cotejo dos sistemas preconizados por Locke e por Montesquieu encontrado em DALLARI, Dalmo de Abreu. Da atualização do Estado, 1963. 146 f. Tese (Livre-Docência) - Faculdade de Direito, Universidade de São Paulo, São Paulo, 1963, p. 119-124.

${ }^{19}$ BONAVIDES, Paulo. Do Estado Liberal ao Estado Social. 9. ed. São Paulo: Malheiros, 2009, p. 47.

${ }^{20}$ MONTESQUIEU, Charles-Louis de Secondat, Barão de La Brède e de. Do espírito das leis. Tradução de Fernando Henrique Cardoso e Leôncio Martins Rodrigues. São Paulo: Abril Cultural, 1979, p. 148-154.
} 
posicionamento dos três órgãos em um mesmo plano de igualdade e de hierarquia, reforçado com mecanismos adicionais de travamento recíproco, de modo que o "poder possa deter o poder".

Em síntese, o Poder Legislativo, praticado pelo Parlamento, cria as leis e corrige ou anula aquelas que foram feitas; o Poder Executivo, manifestado pelo Rei, celebra a paz ou declara a guerra, envia ou recebe embaixadores, instaura a segurança, previne contra invasões; e o Poder Judiciário, representado pelos juízes, julga os crimes ou conflitos entre os particulares.

É necessário registrar que, apesar de Montesquieu, diferentemente de Locke, ter conferido ao poder de julgar o status de um dos poderes do Estado, ${ }^{21}$ inaugurando a tripartipação dos poderes nos moldes mais conhecidos atualmente, é nítido o caráter secundário atribuído por ele a esse poder, conforme se verifica a partir das célebres passagens em Do espírito das leis: (i) "Dos três poderes de que falamos, é o Poder de Julgar, de certo modo, nulo. Sobram dois.",22 e (ii) "[o juiz é] apenas a boca que pronuncia as palavras da lei, seres inanimados que não podem moderar nem sua força nem seu rigor.". ${ }^{23}$

Montesquieu ressalta ser imperioso que as funções executiva, legislativa e judicial não estejam reunidas nas mãos de um único órgão. Sem isso, não existiria a liberdade individual, pois,

Quando, na mesma pessoa ou no mesmo corpo de magistratura, o poder Legislativo é reunido ao Executivo, não há liberdade. Porque pode temer-se que o mesmo Monarca ou mesmo o Senado faça leis tirânicas para executálas tiranicamente. Também não haverá liberdade se o poder de julgar não estiver separado do Legislativo e do Executivo. Se estivesse junto com o Legislativo, o poder sobre a vida e a liberdade dos cidadãos seria arbitrário, pois o juiz seria o legislador. Se estivesse junto com o Executivo, o juiz poderia ter a força de um opressor. Estaria tudo perdido se um mesmo homem, ou um mesmo corpo de principais ou nobres, ou do Povo, exercesse

\footnotetext{
21 A efetiva evolução do Judiciário como um dos Poderes constituídos do Estado se inicia a partir das Revoluções Liberais do século XVIII, âmbito em que aflorou o movimento constitucionalista e o princípio da separação dos poderes, inspirados pelos ideais de liberdade e igualdade. Antes disso, somente é possível falar em história da magistratura, verificada já nas Cidades-Estados gregas, na Grécia Antiga e em Roma, sendo que até o advento do Império Romano, os magistrados eram escolhidos (à exceção das Cidades-Estados gregas, que admitiam o sorteio) por meio de eleição, do que decorria a sua legitimidade. No decorrer do sistema imperial romano, abandonou-se a eleição como forma de escolha dos magistrados, que passaram a ser escolhidos pelo Senado, de modo que, até o final da Idade Média, ficaram vinculados ao monarca, sendo conhecidos como agentes do rei. (DALLARI, Dalmo de Abreu. O poder dos juízes. 3. ed. São Paulo: Saraiva, 2007, p. 10-12.)

${ }_{22}$ MONTESQUIEU, Charles-Louis de Secondat, Barão de La Brède e de. Do espírito das leis. Tradução de Fernando Henrique Cardoso e Leôncio Martins Rodrigues. São Paulo: Abril Cultural, 1979, p. 148-154.

${ }^{23}$ MONTESQUIEU, Charles-Louis de Secondat, Barão de La Brède e de. Do espírito das leis. Tradução de Fernando Henrique Cardoso e Leôncio Martins Rodrigues. São Paulo: Abril Cultural, 1979, p. 148-154.
} 
estes três poderes: o de fazer as leis; o de executar as resoluções públicas; e o de julgar os crimes ou as demandas dos particulares. ${ }^{24}$

Para além de uma divisão de poderes, Montesquieu preconizava fundamentalmente a ideia de uma recíproca limitação de poderes, de tal modo que cada órgão, sem usurpar as funções do outro, pudesse impedir que os demais abusassem de suas funções. Cada um dos três órgãos, portanto, teria a faculdade de estatuir (faculté de statuer) sobre os assuntos afetos às suas funções, ou seja, teria "o direito de ordenar por si mesmo, ou de corrigir o que foi ordenado por outrem",25 e a faculdade de impedir (faculté d'empêcher) que os outros órgãos invistam contra o equilíbrio constitucional das funções estatais, anulando as suas ações contrárias à lei. ${ }^{26}$

Saldanha Junior destaca que a aparente simplicidade dessa fórmula, na verdade, articula:

1. ${ }^{\circ}$ uma classificação ternária de órgãos sociais que vinham evolvendo do Medievo: o Rei (a Coroa), o Parlamento, reunindo a nobreza de espada (na Câmara Alta) e os Comuns ou Terceiro Estado (na Câmara Baixa), bem como o corpo de magistrados (a burocracia togada) (...) o objetivo de Montesquieu é o de instituir um "governo moderado", ou seja, o "regime misto" recomendado por Políbio, Cícero e S. Tomás (...);

2. ${ }^{\circ}$ uma classificação, também ternária, das funções políticas que, desde Aristóteles, ganhava corpo (e um crescente viés jurídico), a saber, a função executiva, a função legislativa e a função judicial (...);

3. ${ }^{\circ}$ uma alocação, a mais exclusiva possível, para cada órgão social, de uma das funções políticas (puissances), transformando-os em poderes políticos (pouvoirs). Assim, o Rei, com a função executiva, é o Poder Executivo; o Parlamento, com a função legislativa, o Poder Legislativo; os juízes, com a função judiciária, o Poder Judiciário (...);

4..$^{\circ}$ um mesmo plano horizontal e mecânico, no qual todos os poderes estariam em pé de igualdade em tudo (hierarquia, independência e potência jurídica), criando-se ipso facto um ambiente de paralisia (...);

5. ${ }^{\circ}$ um espaço para o estabelecimento adicional de freios e contrapesos recíprocos, (...) (por exemplo, o poder de veto, o poder de convocar o Parlamento, o poder de impedir ministros e juízes etc....). ${ }^{27}$

\footnotetext{
${ }^{24}$ MONTESQUIEU, Charles-Louis de Secondat, Barão de La Brède e de. Do espírito das leis. Tradução de Fernando Henrique Cardoso e Leôncio Martins Rodrigues. São Paulo: Abril Cultural, 1979, p. 148-154.

${ }^{25}$ MONTESQUIEU, Charles-Louis de Secondat, Barão de La Brède e de. Do espírito das leis. Tradução de Fernando Henrique Cardoso e Leôncio Martins Rodrigues. São Paulo: Abril Cultural, 1979, p. 168.

${ }^{26}$ CAETANO, Marcello. Manual de ciência política e de direito constitucional. t. I. 6.ed. Coimbra: Almedina, 2006, p. 193.

${ }^{27}$ SALDANHA JUNIOR, Cezar. $O$ tribunal constitucional como poder: uma nova teoria da divisão dos poderes. São Paulo: Memória Jurídica, 2002, p. 57-58.
} 
Apesar da sistematização inédita, grande parte dos revisores e intérpretes da Teoria da Separação de Poderes de Montesquieu afirma que ele nunca pretendeu uma classificação científica das funções do Estado, mas sim fornecer uma "receita juspolítica", nas palavras de Saldanha Junior, ${ }^{28}$ ou uma "receita de arte política", nas palavras de Ferreira Filho. ${ }^{29}$

Com razão Saldanha Junior e Ferreira Filho, uma vez que, no Livro XI de Do espírito das leis, ${ }^{30}$ fica claro o objetivo de Montesquieu de desenhar as linhas fundamentais da organização política necessária à garantia da liberdade, entendida naquele momento como fazer tudo que a lei permite.

Dallari acrescenta que Montesquieu não estaria preocupado em assegurar eficiência ao Estado, parecendo-lhe mais importante a separação tripartida dos poderes para garantia da liberdade individual. ${ }^{31}$ No mesmo sentido, Tercio Sampaio Ferraz Junior afirma que Montesquieu via na divisão de poderes muito mais um preceito de "arte política" do que um princípio jurídico, por meio do qual não se visava à separação de poderes, mas a "inibição de um pelo outro de forma recíproca". ${ }^{32}$

A ideia subjacente à teoria de Montesquieu, como fica claro, era a limitação do poder absoluto do monarca, por meio de sua subordinação à lei. A aversão à concentração do poder verificada no Estado Absolutista foi o que determinou a larga adesão à separação de poderes como modelo de organização política nos Estados de Direito originados a partir das Revoluções Liberais.

Assim é que, antes mesmo do início da Revolução Francesa, de 1789, já na Declaração de direitos da Virgínia, de 1776, consta do parágrafo 5..$^{\circ}$ que os poderes executivo e legislativo do Estado deverão ser separados e distintos do judiciário.

\footnotetext{
${ }^{28}$ SALDANHA JUNIOR, Cezar. $O$ tribunal constitucional como poder: uma nova teoria da divisão dos poderes. São Paulo: Memória Jurídica, 2002, p. 56.

${ }^{29}$ FERREIRA FILHO, Manoel Gonçalves. A democracia no limiar do século XXI. São Paulo: Saraiva, 2001, p. 120. Ferreira Filho observa, ainda, que “(...) é duvidoso que Montesquieu tenha, no célebre capítulo "Da Constituição da Inglaterra", buscado fazer ciência. Bem mais preocupado parece estar ele em pregar um governo moderado pela divisão e repartição do poder, valorizando a lição por atribuí-la ao país na moda, do que em expor rigorosamente a realidade constitucional britânica de seu tempo. Na verdade, em meados do século XVIII, na época em que Montesquieu escreveu sua obra, não havia mais na Grã Bretanha a "separação" nos termos em que a descreve, pois o parlamentarismo - que elimina a independência do Executivo em relação ao Legislativo - já a esse tempo se praticava naquele país." (FERREIRA FILHO, Manoel Gonçalves. Curso de Direito Constitucional. 39. ed. São Paulo: Saraiva, 2013, p. 134.)

${ }^{30}$ MONTESQUIEU, Charles-Louis de Secondat, Barão de La Brède e de. Do espírito das leis. Tradução de Fernando Henrique Cardoso e Leôncio Martins Rodrigues. São Paulo: Abril Cultural, 1979, p. 148-154.

${ }^{31}$ DALLARI, Dalmo de Abreu. A constituição na vida dos povos: da idade média ao século XXI. São Paulo: Saraiva, 2010, p. 184.

${ }^{32}$ FERRAZ JUNIOR. Tercio Sampaio. O Judiciário diante da divisão de poderes: um princípio em decadência? In: _. Direito Constitucional: liberdade de fumar, privacidade, estado, direitos humanos e outros temas. Barueri: Manole, 2007, p. 400.
} 
A coroação da tripartição de poderes como dogma do constitucionalismo clássico e como pressuposto fundamental da democracia se deu com sua inserção na Declaração dos direitos do homem e do cidadão, de 1789, cujo artigo 16 declara que a sociedade em que não esteja garantida a separação de Poderes não tem constituição.

Essa preocupação com a proteção da liberdade por meio da separação dos poderes refletiu imediatamente em todo o movimento constitucionalista clássico, tendo sido reproduzida nas Constituições das ex-colônias britânicas e na Constituição dos Estados Unidos de 1787, nas Constituições francesas de 1791 e 1795, na Constituição espanhola de 1812 e na Constituição de Portugal de 1822. Ainda, após a independência da América Latina, a fórmula de Montesquieu (mesmo que com algumas adaptações) acabou sendo consagrada formalmente pela quase totalidade dos seus Estados, inclusive pela Constituição brasileira de 1891.

Entretanto, Rubens Beçak ressalta que a inclusão generalizada do princípio da separação de poderes como "fórmula constitucional" das constituições liberais provocou, em alguma medida, uma adoção irrefletida das teses de Montesquieu, o que este jamais pretendera. ${ }^{33}$ Isso porque uma receita claramente "política" acabou sendo aplicada tal qual uma fórmula jurídica absolutamente científica. Segundo Ferreira Filho, prevaleceu e ainda prevalece até hoje "mundo afora" uma "visão juridicista e simplificada" da Teoria da Separação de Poderes de Montesquieu. ${ }^{34}$

Essa "visão juridicista e simplificada" conferiu à teoria de Montesquieu um caráter muito mais estático do que parece ter originalmente pretendido o pensador. A fórmula do filósofo francês foi vendida ao longo dos séculos como teoria de separação absoluta dos poderes estatais, segundo a qual cada Poder está autorizado a exercer estritamente uma única função. No entanto, é evidente que o preceito absoluto diz respeito à atividade predominante e primeira daquele Poder, tendo em vista que o exercício de suas tarefas depende da prática de outras funções que não lhe são atinentes. ${ }^{35}$ Mencione-se, como exemplo, a figura do veto, que representa real interferência do Poder Executivo no processo legiferante.

O próprio Montesquieu entendia que a cada poder deveria ser atribuída não só a faculdade de decidir ou de estatuir sobre as matérias de sua competência, mas também a

\footnotetext{
${ }^{33}$ BEÇAK, Rubens. A hipertrofia do Executivo brasileiro: impacto da Constituição de 1988. 2005. 184 p. Tese (Doutorado) - Faculdade de Direito, Universidade de São Paulo, São Paulo, 2005, p. 33.

${ }^{34}$ FERREIRA FILHO, Manoel Gonçalves. A democracia no limiar do século XXI. São Paulo: Saraiva, 2001, p. 120.

35 BEÇAK, Rubens. O Tribunal Constitucional e sua intervenção no processo político. Disponível em: www.conpedi.org.br/manaus/arquivos/anais/salvador/rubens_becak.pdf. Acesso em: 20 Ago. 2012, p. 2762.
} 
faculdade de refrear ou impedir que os outros poderes pratiquem atos contrários ao Direito ou ao equilíbrio constitucional, paralisando a ação deles quando exorbitantes ou anulando os seus atos ilegais.

Carré de Malberg explica que

El pensamiento de Montesquieu, dícese, nunca fue que los tres poderes hubieran de estar separados en el sentido propio de la palabra, o sea repartidos orgánicamente entre autoridades que representaran o expresaran tres voluntades estatales distintas. Su idea es, sencillamente - como él mismo lo explica -, que la libertad desparecería y quedaría reemplazada por el despotismo si dependiera el ejercicio de la potestad de Estado, enteramente y sin reparto, de la voluntad de un solo hombre o de una sola asamblea. $^{36}$

Pode-se dizer, portanto, que a Teoria da Separação de Poderes vem sendo modificada desde a sua gênese, não só em razão da interpretação a ela conferida, como em razão de pequenas adaptações que sofreu no processo de recepção pelos diferentes Estados do Ocidente, em conformidade com o processo histórico e necessidades particulares de cada um deles.

Esse é o caso emblemático dos Estados Unidos da América, ${ }^{37}$ que, embora inicialmente tenha adotado a teoria da separação de poderes nos moldes originários ingleses (Legislativo destacado), findou por criar uma revisão do modelo preconizado por Montesquieu, que passou a ser conhecida como sistema de freios e contrapesos (ou de checks and balances), o qual será conceituado adiante.

As constituições das antigas 13 colônias britânicas, promulgadas imediatamente após sua independência, em 1776, caracterizaram-se pela forma de governo assembleística, dominada pelos órgãos legislativos locais, que se sobrepunham ao Executivo. ${ }^{38}$ Alexandre de

\footnotetext{
${ }^{36}$ MALBERG, Raymond Carré de. Teoría general del Estado. Traducción de José Lión Depetre. México: Fondo de Cultura Económica, 1948, p. 758.

37 "O livro de MONTESQUIEU foi publicado em 1784 e teve larga difusão na Europa. Tem-se pretendido que não influiu na elaboração da Constituição americana de 1787, a qual procuraria sobretudo reproduzir o sistema inglês "tal como ele se apresentava aos olhos de um observador da segunda metade do século XVIII". Tal afirmação não é exacta. Não pode negar-se que os norte-americanos, na fase de independência em que tão auxiliados foram pela França, tiveram presente a interpretação que desse sistema fazia um dos maiores escritores políticos da época, tanto que em 1811 era publicado nos Estados Unidos, por iniciativa de JEFFERSON, a quem fora oferecido, um livro do CONDE DE TRACY de Comentários ao Espírito das Leis de Montesquieu, o qual não veria a publicidade nem o êxito que teve se a obra comentada não gozasse de grande voga." (CAETANO, Marcello. Manual de ciência política e de direito constitucional. t. I. 6.ed. Coimbra: Almedina, 2006, p. 194.)

${ }^{38} \mathrm{Nem}$ todas as ex-colônias podem ser incluídas nessa regra, pois os Estados de Rhode Island e Connecticut não adotaram constituições e os Estados de Nova York e de Massachussets, embora as tivessem adotado, não adotaram a forma de governo assembleística referida. Cf. LUCARELLI, Alberto. Teorie del presidenzialismo: fondamento e modelli. Verona: Cedam, 2000, p. 121-126.
} 
Moraes deixa claro que a opção de destaque ao Legislativo deveu-se à intenção de afastar do sistema de governo a figura dos governantes, haja vista a centralização de poder nestes indivíduos durante o período colonial. Desse modo, os pais fundadores americanos pretenderam transferir o poder dos cargos administrativos para seus legislativos estaduais, com vistas à implementação de um regime de governo semelhante ao parlamentarismo constitucional inglês, mas sem a figura do rei. ${ }^{39}$

Não obstante, já em 1787, diante da fragilidade desse modelo assembleístico, tanto nas relações entre os próprios Estados membros quanto nas relações destes com outros Estados soberanos, e sob a influência da campanha deflagrada pelos defensores do Federalismo, em especial James Madison, Alexander Hamilton e John Jay, foi convocada uma Convenção Federal, na Filadélfia, para revisão dos chamados “Artigos da Confederação" de $1781 .{ }^{40}$

Em $O$ Federalista, ${ }^{41}$ obra fruto da reunião de 85 ensaios escritos por Alexander Hamilton, James Madison e John Jay, e publicados na imprensa de Nova York em 1788, seus autores, em especial os primeiros (Hamilton e Madison), tendo em mira as lições de Montesquieu, propuseram a construção de um novo modelo de separação dos poderes. A proposta dos autores se afastava do modelo europeu, que outorgava ao Poder Legislativo papel proeminente. Ao contrário, fundava-se na mitigação da supremacia do Poder Legislativo, conferindo maior equilíbrio à relação entre os poderes, porém, com o fortalecimento do Poder Executivo.

Desse modo, a Convenção da Filadélfia resultou no estreitamento dos vínculos dos Estados membros por meio da adoção do modelo da Federação, ${ }^{42}$ com a consequente criação

\footnotetext{
${ }^{39}$ MORAES, Alexandre de. Presidente da República: a força motriz do presidencialismo. 2003. 387 f. Tese (Titular) - Faculdade de Direito, Universidade de São Paulo, São Paulo, 2003, p. 12-13.

${ }^{40}$ Os "Artigos da Confederação" representam o pacto confederal entre as antigas colônias inglesas da América do Norte. A necessidade de revisão desse pacto deveu-se ao fato de que a Assembleia da Confederação, constituída pelos Estados, todos com voto paritário, não dispunha de qualquer poder governamental. Segundo Nina Ranieri: "Era pouco mais que uma reunião de embaixadores despreparados para solucionar os conflitos de interesse entre os Estados, o que prejudicava a ação conjunta da Federação e ameaçava sua própria sobrevivência. Nesse contexto, vários líderes da Revolução Americana passaram a defender a criação de um governo central, na tentativa de equacionar os problemas políticos, administrativos e econômicos dos Estados Confederados." (RANIERI, Nina. Sobre o federalismo e o estado federal. Cadernos de direito constitucional e ciência política. Revista dos Tribunais. Ano 3, n. 9, p. 87-102, out/dez. 2004, p. 88.)

${ }^{41}$ Cf. HAMILTON, Alexander; MADISON, James; JAY, John. O federalista. São Paulo: Victor Civita Editor, 1979. (Os Pensadores).

${ }^{42}$ Cumpre explicitar, ainda que brevemente, excelente síntese da diferença entre Confederação e Estado Federal, elaborada por Nina Ranieri: "Na Confederação busca-se a união apenas da gerência dos interesses comuns, mantida a individualidade dos Estados soberanos que a congregam mediante contrato. No Estado Federal o pacto associativo é constitucional, e suprime a soberania das unidades o integram para dar origem a uma entidade jurídico-política superior." (RANIERI, Nina. Sobre o federalismo e o estado federal. Cadernos de direito constitucional e ciência política. Revista dos Tribunais. Ano 3, n. 9, p. 87-102, out/dez. 2004, p. 89.)
} 
de um Executivo forte e centralizador, por meio do regime de governo presidencialista, em contraposição aos Parlamentos existentes e ao regime de governo parlamentarista inglês. ${ }^{43}$

Essa adaptação da Teoria da Separação dos Poderes de Montesquieu visava não à independência ou ao isolamento entre os Poderes estatais, mas, ao invés disso, à atuação concertada, equilibrada e harmônica entre os Poderes, de tal modo que fossem interdependentes e funcionassem de acordo com um equilíbrio dinâmico.

Destaque-se a que a fórmula de Montesquieu, de atribuição a cada um dos Poderes da faculdade de refrear os demais ou de impedi-los que pratiquem atos contrários ao Direito ou ao equilíbrio constitucional, não pode ser confundida com o sistema de freios e contrapesos, este atento fundamentalmente à efetiva cooperação entre os poderes. Carré de Malberg deixa bastante clara a distanciação entre a fórmula de Montesquieu e a colaboração propriamente dita entre Poderes, tal qual presente no sistema de freios e contrapesos:

(...) en ninguna parte, pone Montesquieu en evidencia ni parece siquiera advertir la necesidad superior, para los titulares de los poderes separados, de coordinar sus actividades respectivas asociándolas y fundándolas en una acción común, de modo que se asegure mediante esta cooperación la unidad de fines y de resultados que demanda la misma unidad del Estado. Montesquieu no se preocupa de aproximar las potestades que empezó por disociar; se limita, a este respecto, a reivindicar para ellas mutuas facultades de "impedirse", "obligarse", "encadenarse", lo que es muy diferente de una colaboración o entendimiento común. ${ }^{44}$

Com efeito, nas palavras de Thomas Jefferson, citado por Marcello Caetano, o sistema de freios e contrapesos pode ser definido como aquele em que "os poderes estão de tal fora repartidos e equilibrados entre os diferentes órgãos que nenhum pode ultrapassar os limites estabelecidos na Constituição sem ser eficazmente detido e contido pelos outros." ${ }^{45}$ Ou seja, ao invés de atribuir cada função a seu órgão especializado, a Constituição americana

\footnotetext{
${ }^{43}$ Sobre a fundamental diferença entre as diferentes conformações sobre a teoria da separação de Poderes na Europa e nos Estados Unidos, confira-se: "Enquanto na família da Civil Law, o princípio foi chamado a garantir a soberania do Parlamento, impedindo que houvesse controles recíprocos entre os Poderes, eis que estes não estavam equiordenados, dando à separação de Poderes o papel de garantidor da supremacia de um dos órgãos; na família da Common Law, em especial nos Estados Unidos, a ideia liberal de primado da lei não gerou a noção de supremacia do legislador, com uma visão mais realista da função jurisdicional e de um princípio de constitucionalidade, além da desconfiança da antiga colônia em relação ao abuso do Parlamento inglês." (MORGADO, Cíntia. A nova face da separação de poderes: capacidades institucionais, vinculação dos poderes e constitucionalismo cooperativo. Revista de Direito Processual Geral, Rio de Janeiro, n. 66, p. 64-93, 2011, p. 67.).

${ }^{44}$ MALBERG, Raymond Carré de. Teoría general del Estado. Traducción de José Lión Depetre. México: Fondo de Cultura Económica, 1948, p. 758.

${ }^{45}$ CAETANO, Marcello. Manual de ciência política e direito constitucional. t. I. 6. ed. Coimbra: Almedina, 2006, p. 195.
} 
fracionou as funções e estabeleceu a colaboração forçada de vários órgãos no exercício de cada uma.

Ainda, acerca da instrumentalização do sistema de freios e contrapesos, Carlos Ayres Britto ensina que deve haver

(...) atribuição das três clássicas funções estatais a cada poder governamental, sendo que uma em caráter principal, finalístico, e duas em caráter secundário, instrumental. Assim, "verbia gratia", o Poder Judiciário teria por função preponderante e específica o julgamento dos litígios entre as pessoas físicas e jurídicas, e, num plano acessório e inespecífico, o desempenho de atividades administrativas e legislativas. O Executivo operaria na faixa da execução das leis, "ex officio", de modo principal. Secundariamente, atuaria no campo da legislação e da jurisdição. E o Poder Legislativo, na esteira dessa orientação, faria breves incursões nos domínios da jurisdição e da administração; (... $)^{46}$

Demais disso, Carlos Ayres Britto alerta que a fórmula acima deve ser complementada com uma refinada técnica de atribuição de uma função relevante do Estado, não a um órgão isoladamente, mas a dois deles ou até mesmo a todos em conjunto. Isto é,

(...) para a prática de determinado ato, ou exercício de certa função, tonar-seia necessária a participação de mais de um Poder, numa espécie de colaboração forçada. E para efeito de contenção de cada Poder nas fronteiras da sua competência constitucional, todos disporiam de meios eficientes para impedir a usurpação de funções e fazer refluir o órgão exorbitante para os limites daquele espaço em que a atuação dele seria legítima. ${ }^{47}$

Como Anna Cândida da Cunha Ferraz, pode-se concluir que o sistema de freios e contrapesos, criado nos Estados Unidos, "atenuando a independência em benefício da harmonia [entre os Poderes], (...), se não eliminou, ao menos minimizou os conflitos e impediu a preponderância de um Poder sobre o outro.". 48

Contemporaneamente, essa é a fórmula vigente em grande parte dos Estados ocidentais, principalmente os latino-americanos, diretamente influenciados pelo modelo norte americano que associou a Teoria da Separação de Poderes ao sistema de freios e contrapesos, bem como ao regime de governo presidencialista.

\footnotetext{
${ }^{46}$ BRITTO, Carlos Ayres. Separação de poderes na Constituição brasileira. Revista de Direito Público, n. 59/60, p. 115-127, Jul/dez. 1981, p. 121.

${ }^{47}$ BRITTO, Carlos Ayres. Separação de poderes na Constituição brasileira. Revista de Direito Público, n. 59/60, p. 115-127, Jul/dez. 1981, p. 121.

${ }^{48}$ FERRAZ, Anna Cândida da Cunha. Conflito entre Poderes: o poder congressual de sustar atos normativos do Poder Executivo. São Paulo: Revista dos Tribunais, 1994, p. 18.
} 
Contudo, apesar da larga adoção dessa fórmula, é incorreto afirmar que o Poder Executivo sempre se destacou e sempre se destacará entre os demais.

Isso porque, independentemente do sistema de freios e contrapesos, a História revela que, ao longo da evolução do Estado, houve necessidade de que algumas funções específicas de determinado Poder fossem desenvolvidas por outros, do que decorreu, além de necessárias adaptações na organização dos Poderes, o protagonismo de cada um deles em diferentes momentos no decorrer dos séculos XIX, XX e XXI.

Desse modo, cumpre destacar brevemente a evolução das relações entre os Poderes Executivo, Legislativo e Judiciário após a Revolução Francesa de 1789, de modo que se possa visualizar e compreender o protagonismo do Poder Legislativo no século XIX, o protagonismo do Poder Executivo no século XX e o protagonismo do Poder Judiciário no século XXI - questão que, particularmente, interessa para o desenvolvimento dos capítulos seguintes.

1.3. Separação e protagonismo dos Poderes entre os séculos XVIII e XXI

Como se verificou acima, a análise da evolução da Teoria da Separação de Poderes de Montesquieu sugere que sua aplicação deve adaptar-se às características específicas de cada Estado, considerando o momento histórico destes. Nessa medida, a referida análise suscita uma das grandes questões constitucionais do presente, a saber, a "hipertrofia das funções do Estado", como Gariel Almond e J. S. Coleman ${ }^{49}$ denominam o fenômeno, ou a “multifuncionalidade do Estado contemporâneo", nas palavras de Cristina Queiroz. ${ }^{50}$

Quer-se dizer com isso que as funções do Estado se desenvolvem de tal forma que, a depender de fatores externos à estrutura organizacional dos Poderes, tais como a política, a economia e as questões sociais, os Poderes passam a se destacar no desempenho de suas funções principais ou assumem o exercício de funções antes reservadas a outro Poder.

\footnotetext{
49 ALMOND, Gabriel; COLEMAN, James. The politics of developing areas. Princeton: Princeton University Press, 1960, p. 26 e 58.

${ }^{50}$ QUEIROZ, Cristina. Os actos políticos no Estado de Direito. Coimbra: Almedina, 1990, p. 99.
} 
Ricardo Enrique Lewandowski utiliza a expressão "protagonismo" ${ }^{\text {,51 }}$ dos Poderes para se referir ao cenário em que um Poder, notadamente, se destaca dentre os demais.

O estudo das relações entre os Poderes e do fenômeno do protagonismo de cada um deles implica na compreensão de que, ainda que o modelo tripartite de Montesquieu venha servindo como base para a organização dos Poderes, desde a sua inserção nas constituições promulgadas no contexto das Revoluções Liberais, a organização e a distribuição das funções estatais não escapa à natural necessidade de adaptação dos Poderes às circunstâncias políticas, sociais e econômicas verificadas em determinados momentos históricos.

Com efeito, o resultado imediato da própria Revolução Francesa de 1789, dentro da recém adotada separação tripartite dos Poderes, foi a posição de destaque, ou protagonismo, do Poder Legislativo dentre os demais, consequência do fundado receio da burguesia com relação ao absolutismo real até então vigente. Era sentida a necessidade de defesa da liberdade individual, a qual, agora garantida pela constituição e por leis, dependia fundamentalmente do exercício da função legislativa.

A Revolução Francesa de 1789 foi o grande divisor de águas no desenvolvimento do Estado e do constitucionalismo. Inspirada pelos ideais iluministas, humanistas e racionalistas, ela marcou a queda do Estado Absolutista e o início do Estado de Direito, a conquista do poder político pela burguesia, ${ }^{52} \mathrm{o}$ início movimento constitucionalista clássico, e marcou o início da primeira geração dos direitos humanos, ${ }^{53}$ exaltando a liberdade individual.

\footnotetext{
${ }^{51}$ LEWANDOWSKI, Enrique Ricardo. O protagonismo do Poder Judiciário na era dos direitos. Revista de Direito Administrativo, n. 251, p. 77-85, mai/ago. 2009.

${ }^{52}$ Rubens Beçak bem elucida que, "classe em evidente formação, dentro do estamento até sem nome que era o Terceiro Estado, a burguesia já amealhava poder social que lhe possibilitava identificação e relevância. É certo também que detinha o poder econômico, sendo detentora dos meios de produção e titular dos meios possibilitadores do fluxo financeiro. Faltava-lhe o poder político e é este que vamos verificar ter árdua e revolucionariamente conseguido na Era das Revoluções, a qual, se por um lado tem a primazia ímpar da Revolução Inglesa de 1688, por outro adquire forma e deslanchar com as Revoluções Americana de 1776 e Francesa de 1789." (BEÇAK, Rubens. A hipertrofia do Executivo brasileiro: impacto da Constituição de 1988. 2005. 184 p. Tese (Doutorado) - Faculdade de Direito, Universidade de São Paulo, São Paulo, 2005, p. 88-89.) Sobre o aspecto burguês do Estado Liberal, cf. SIEYÈS, Emmanuel Joseph. A Constituinte Burguesa: Qu'est-ce que le Tiers État?. Organização e Introdução de Aurélio Wander Bastos. Tradução de Norma Azevedo. 4. ed. Rio de Janeiro: Lumen Juris, 2001.

${ }^{53} \mathrm{Na}$ concepção de Norberto Bobbio, os direitos humanos se afirmaram historicamente em quatro gerações, sendo que a primeira delas refere-se aos direitos conquistados nas Revoluções Liberais (especialmente a Francesa), ou seja, os direitos individuais, os quais pressupõem a igualdade formal perante a lei e consideram o sujeito abstratamente. A segunda geração abriga os direitos coletivos ou direitos sociais, nos quais o sujeito de direito é visto no contexto social, ou seja, analisado em uma situação concreta. Os direitos humanos de terceira geração são os direitos dos povos ou direitos de solidariedade, os quais basicamente compreendem os direitos do consumidor e os relacionados à questão ecológica. Por fim, a quarta geração compreende os direitos de manipulação genética, relacionados à biotecnologia e à bioengenharia e que tratam de questões sobre a vida e a morte, requerendo discussão ética prévia. Para aprofundamento sobre as gerações de direitos fundamentais, cf. BOBBIO, Norberto. A era dos direitos. Rio de Janeiro: Campus Elsevier, 2004.
} 
A efetiva separação dos poderes, sob o critério funcional, e a adoção de uma constituição formal foram os principais instrumentos para a consecução dos objetivos da Revolução, isto é, a limitação do poder do monarca e a tutela dos direitos à liberdade individual e à igualdade dos indivíduos perante a lei, os quais ficaram evidenciados na Constituição Francesa de 1791.

Assim é que o Estado Moderno, surgido a partir das Revoluções Liberais, nasce não apenas como um Estado de Direito, mas também como um Estado Constitucional, de modo que todos, inclusive o monarca, passaram a estar submetidos ao império da lei e da constituição. ${ }^{54,55} \mathrm{O}$ poder estatal, até então fundamentado na vontade divina e atribuído ao rei, passa à titularidade da nação e passa a atender à vontade dessa nação, que expressa o poder estatal por meio das leis.

Segundo as teorias de Jean Jacques Rousseau e de John Locke, a lei passaria a ser a expressão maior do pacto social e símbolo da coesão da sociedade, agora desagregada pela desmistificação do estado de natureza determinado pelo absolutismo monárquico. ${ }^{56,57}$

O poder político do Estado, nessa concepção, é refletido na própria lei, cujo papel de destaque no contexto revolucionário pode ser assim sintetizado:

O princípio da primazia da lei servia para a submissão ao direito do poder político "sob um duplo ponto de vista": (1) os cidadãos têm a garantia de que a lei só pode ser editada pelo órgão legislativo, isto é, o órgão representativo da vontade geral (cf. Déclaration de 1789, artigo 6..$^{\circ}$; (2) em virtude da sua

\footnotetext{
${ }^{54}$ Vale ressaltar que, inicialmente, a importância atribuída à lei é sensivelmente maior do que aquela dispensada à constituição em si, o que fica bastante evidente na França por meio da grandiosidade do Código Civil de 1804, conhecido como "Código Napoleônico". Apenas com o advento da Constituição de 1958, passou a existir na França o governo da Constituição. Para aprofundamento dessa questão, cf. DALLARI, Dalmo de Abreu. A constituição na vida dos povos: da Idade Média ao século XXI. São Pulo: Saraiva, 2010, p. 224-228.

${ }^{55}$ Deve-se destacar que, com inspiração nas ideias de Rousseau, a Revolução de 1789 consagrou amplamente a retórica da legalidade, um dos fundamentos do Estado de Direito. A acentuada valoração da lei comum provocou um relativo obscurecimento do caráter normativo das constituições. Segundo Edil Batista Junior, "Tal fenômeno decorreu da primazia política dos parlamentos europeus, que fomentavam a superioridade da lei no sistema normativo continental. Inexistindo controle sobre o resultado parlamentar, inexistia igualmente controle de constitucionalidade das leis." Cf. BATISTA JUNIOR, Edil. O Supremo Tribunal Federal e o monopólio da hermenêutica constitucional no Brasil. Curitiba: Juruá, 2011, p. 29. No mesmo sentido, Gustavo Zagrebelsky afirma que lei e constituição passaram a ter, quando muito, igual valor. O texto constitucional, conquanto possuísse aplicabilidade imediata, tornava-se mera orientação ao legislador. (ZAGREBELSKY, Gustavo. El derecho dúctil: ley, derechos, justicia. Tradução de Marina Gascón. 5. ed. Madrid: Trotta, 2003, p. 53).

${ }^{56}$ LOCKE, John. Segundo tratado sobre o governo. Tradução de E. Jaci Monteiro. São Paulo: Ibrasa, 1963, p. 69 e 92 e ss.

${ }^{57}$ André Ramos Tavares ensina que o conceito iluminista de lei, predominante ao longo do século XIX até princípios do século XX, "resultou, de certa forma, de uma convergência dos pensamentos de Rousseau e Kant. Rousseau defendeu a soberania pelo império absoluto da lei. Kant concebeu a lei não apenas com referência à soberania do povo, mas igualmente da razão. A vontade geral, que em Rousseau parecia pouco precisa, foi, por Kant, desenvolvida e clarificada em termos de vontade racional. Burdeau observa a esse respeito: "Que base mais prestigiosa se poderia ter dado à lei do que aquela que se encontrava na dupla soberania do povo e da razão?"." (TAVARES, André Ramos. Curso de direito constitucional. 8. ed. São Paulo: Saraiva, 2010, p. 1184.)
} 
dignidade - obra dos representantes da Nação - a lei constitui a fonte de Direito hierarquicamente superior (a seguir às leis constitucionais) e, por isso, todas as medidas adoptadas pelo poder executivo a fim de lhe dar execução deviam estar em conformidade com ela (princípio da legalidade da administração). Mas não só isso: como produto da vontade geral, as leis eram necessariamente gerais (generalidade da lei) garantindo, desse modo, a observância do princípio da igualdade perante a lei e consequente repúdio das velhas leges privatae (privilégios) características do Ancien Régime. ${ }^{58}$

Do evidente caráter legalista das Revoluções Liberais surgiu, portanto, o Estado de Direito, fundado na soberania do povo. Como bem ensina Eliaz Díaz, os quatro elementos que permitem caracterizar o Estado de Direito já naquele momento se faziam presentes. São eles:

a) Imperio de la ley: ley como expresión de la voluntad general. b) División de poderes: legislativo, ejecutivo y judicial. c) Legalidad de la Administración: actuación según ley y suficiente control judicial. d) Derechos y libertades fundamentales: garantía jurídico-formal y efectiva realización material. ${ }^{59}$

No entanto, a Revolução Francesa levou à consumação de uma ordem social essencialmente burguesa, em que se destacavam a liberdade e a igualdade, e, por consequência, à consagração da filosofia do liberalismo. Por isso, inicialmente, o Estado de Direito ficou cunhado como Estado Liberal de Direito, estando limitado, por meio da lei, “à defesa da ordem e da segurança públicas (...), remetendo-se os domínios econômicos e sociais para os mecanismos de liberdade individual e da liberdade de concorrência.". ${ }^{60,61}$

Destaque-se que a liberdade no Estado Liberal refere-se a "uma "liberdade de defesa" ou de "distanciação" perante o Estado. É uma liberdade liberal que "curva" o poder.". ${ }^{2}$ Daí a notória diferenciação, de Benjamin Constant, entre a liberdade dos modernos (assentada na distanciação do poder) e a liberdade dos antigos (assentada na participação no poder). ${ }^{63}$

\footnotetext{
58 CANOTILHO, José Joaquim Gomes. Direito Constitucional e Teoria da Constituição. 4. ed. Coimbra: Almedina, 2000, p. 95-96.

${ }^{59}$ DÍAZ, Eliaz. Estado de derecho y sociedad democrática. Madrid: Taurus, 1998, p. 44.

${ }^{60}$ CANOTILHO, Jose Joaquim Gomes. Direito Constitucional e Teoria da Constituição. 4. ed. Coimbra: Almedina, 2000, p. 97.

${ }^{61}$ Segundo Paulo Bonavides, “[a] Revolução Francesa, por seu caráter preciso de revolução da burguesia, levara a consumação de uma ordem social, onde pontificava, nos textos constitucionais, o triunfo total do liberalismo. Do liberalismo apenas, e não da democracia, nem da democracia política." (BONAVIDES, Paulo. Do Estado Liberal ao Estado Social. 9. ed. São Paulo: Malheiros, 2009, p. 43.)

${ }^{62}$ CANOTILHO, José Joaquim Gomes. Direito Constitucional e Teoria da Constituição. 4. ed. Coimbra: Almedina, 2000, p. 99.

${ }^{63}$ Cf. CONSTANT, Benjamin. A liberdade dos antigos comparada à liberdade dos modernos. Tenacitas: Lisboa, 2001.
} 
No contexto de exaltação da garantia dessa "liberdade de defesa" por meio das leis, parece sintomático que o Poder Legislativo, responsável por sua elaboração, seria eleito para figurar destacadamente diante dos demais Poderes, aos quais cumpria, em síntese, observar as leis e garantir o livre exercício delas. O próprio Immanuel Kant, filósofo do Estado de Direito e do entendimento liberal do direito, admitiu, por influência direta de Rousseau, a identificação do Legislativo com a soberania, sediada no povo e expressa sempre na vontade geral. $^{64}$

Com efeito, embora Montesquieu refira-se teoricamente a um necessário equilíbrio entre as funções do Estado, na prática, concedeu grande valor à figura do legislador, como elo entre o povo e o governo. A supremacia do discurso legislador em face dos demais Poderes na formação do Estado moderno atingiu seu apogeu com as ideias de Rousseau, para quem a lei é sempre instrumento de liberdade, uma vez que a vontade geral elimina a injustiça e a opressão. ${ }^{65}$ É com esse pensador que a lei ganha contornos de instrumento inatacável, vinculativo e redutor da discricionariedade interpretativa do Judiciário. ${ }^{66}$

Em vista disso, André Ramos Tavares pondera que, no Estado de Direito de legalidade, que se constituiu para realizar o sentido conferido à lei pelo iluminismo, "o princípio da separação dos poderes serve para garantir o primado da lei e, assim, o monismo do poder centrado no Legislativo. Não há, nesta concepção, qualquer pretensão de equilíbrio de poderes.". 67

O mesmo autor, com base nos ensinamentos de Nuno Piçarra, conclui que, a partir da legalidade iluminista, o reconhecimento da hierarquia entre as funções estatais implica, necessariamente, em uma hierarquia dos respectivos órgãos, o que pode ser explicado a partir do ensinamento de Kant, "para quem os três poderes-funções estão entre si como as três

\footnotetext{
${ }^{64}$ SALDANHA, Nelson. O estado moderno e a separação de poderes. Saraiva: São Paulo, 1987, p. 99.

${ }^{65}$ Especialmente nos capítulos I e XI do Livro Terceiro do sempre lembrado Do Contrato Social, Rousseau defende o primado do Legislativo sobre o Executivo: "O princípio da vida política está na autoridade do soberano. O poder Legislativo é o coração do Estado, o poder Executivo é o cérebro, que dá movimento a todas as partes. O cérebro pode cair em paralisia e o indivíduo continuar vivendo. (...) Não é pelas leis que o Estado subsiste, é pelo poder Legislativo." (ROUSSEAU, Jean Jacques. Do contrato social. 3. ed. Tradução revista por José Cretella Junior e Agnes Cretella. São Paulo: RT, 2012, p. 133-135.)

${ }^{66}$ A esse respeito, veja-se o seguinte esclarecimento: "A criação e a interpretação da lei, portanto, devem ser atos exclusivos do legislador. O Executivo e o Judiciário passam a ser meras funções do Estado, diversamente do Legislativo, verdadeiro Poder inalienável e indivisível. (...) Rousseau estabeleceu, destarte, o significado da hegemonia legal, bandeira vitoriosa dos revolucionários franceses e da tese da supremacia do Poder Legislativo sobre os demais Poderes." (BATISTA JUNIOR, Edil. O Supremo Tribunal Federal e o monopólio da hermenêutica constitucional no Brasil. Curitiba: Juruá, 2011, p. 28.)

${ }^{67}$ TAVARES, André Ramos. Curso de direito constitucional. 8. ed. São Paulo: Saraiva, 2010, p. 1184.
} 
premissas de um silogismo: premissa maior é o Poder Legislativo, premissa menor o Poder Executivo e conclusão o Poder Judiciário.”. 68

Assim, o século XIX, ao longo do qual foram assentadas as conquistas advindas das Revoluções do final do século XVIII, foi, na prática, dominado pela exaltação da legalidade e da centralização da produção das leis no Legislativo, como forma de desvinculação do absolutismo monárquico.

Enrique Ricardo Lewandowski acrescenta que o protagonismo do Poder Legislativo durante o século XIX deveu-se também ao fato de que o processo legislativo, naturalmente complexo e, por isso, lento, adaptava-se ao Estado Liberal (Estado Mínimo) e às necessidades da sociedade, majoritariamente rural:

O século XIX foi o século do Poder Legislativo, o século do Estado Mínimo, do Estado não intervencionista, Estado que presidia uma sociedade predominantemente rural. Claro que existiam cidades, mas a vida era praticamente uma vida rural, uma vida onde o tempo transcorria de forma muito lenta; então, era perfeitamente possível que a tomada de decisão se desse num fórum relativamente grande, complexo, no que diz respeito à tomada de decisão, que era o Poder Legislativo, e que, por sinal, naquele momento histórico, concentrava aqueles que empolgavam o poder político em suas mãos, que era a burguesia triunfante, que vinha das revoluções liberais burguesas do século imediatamente antecedente, como grande parcela da sociedade vencedora, seja no âmbito econômico, seja no âmbito político. ${ }^{69}$

Ao mesmo tempo em que Legislativo despontava como inquestionável protagonista dentre os Poderes em fins do século XVIII, ${ }^{70}$ o liberalismo econômico ensejou uma postura abstencionista do Estado (Poder Executivo), restando ao Poder Judiciário arvorar-se num comportamento politicamente neutro, principalmente materializado no método de aplicação do direito, a saber, a mera subsunção do fato à letra da lei.

Com efeito, considerando-se a baixa complexidade social da época, a crença na construção de leis estáveis, que permitissem a previsibilidade do resultado das ações

\footnotetext{
${ }^{68}$ TAVARES, André Ramos. Curso de direito constitucional. 8. ed. São Paulo: Saraiva, 2010, p. 1185.

${ }^{69}$ LEWANDOWSKI, Enrique Ricardo. O protagonismo do Poder Judiciário na era dos direitos. Revista de Direito Administrativo, n. 251, p. 77-85, mai/ago. 2009, p. 78.

70 "Interessa ainda anotar, de passagem, que Kelsen, em sua Teoria geral do Estado ( $\$ 37$ ), aceitando implicitamente a noção de uma supremacia do Legislativo, criticou da teoria da separação (sem, todavia, recusála) o fato de ignorar ou dificultar a conveniência de submeter a administração aos controles parlamentares. Anote-se igualmente que, já em fins do século passado (1884), Woodrow Wilson - em seu livro sobre o governo congressional - enxergava na realidade política norte-americana uma insofismável supremacia do Congresso, tendo as disposições clássicas, referentes à separação de poderes, ficado apenas na letra da Constituição." (SALDANHA, Nelson. O estado moderno e a separação de poderes. Saraiva: São Paulo, 1987, p. 103.)
} 
humanas, fez surgir a ideia do legislador universal, conferindo ao Poder Executivo e, principalmente, ao Poder Judiciário um papel secundário no cenário sociopolítico. Ao juiz cabia, portanto, uma atuação mecânica, limitada à utilização do critério gramatical para a compreensão dos textos normativos, a fim de encontrar e aplicar normas legais instrumentais sem o mínimo de discricionariedade interpretativa.

Nelson Saldanha explica que, em princípio e, sob a mira histórica, o predomínio institucional do Legislativo correspondeu a uma exigência de controle sobre o poder estatal como um todo, sobre sua extensão e seu exercício. Naturalmente, esse controle deveria advir da vontade geral, que, no sentido dos séculos XVIII e XIX, correspondia efetivamente à consciência social, a qual, por sua vez, deveria ser sempre a consciência de liberdade. Assim, o controle sobre o poder deveria exercer-se através de instituições legislativas, por ser a lei expressão da vontade geral e por ser a forma civilizada das normatividades jurídicopolíticas. $^{71}$

Manoel Gonçalves Ferreira Filho destaca que o protagonismo do Poder Legislativo teve seu ponto máximo na França, com a Constituição da Terceira República, a qual, por investir o Parlamento não apenas do poder legislativo, mas também do poder constituinte, fez dele, na prática, o órgão supremo do Estado. ${ }^{72}$

E em sagaz observação, continua:

Aqui já manifesta o exagero que, segundo mostra a experiência, não raro precede a queda. E esse exagero que chega a ponto de identificar a soberania do Estado com a soberania do Parlamento, a onipotência do Legislativo com a realização da democracia, é a própria negação da "separação de poderes". Esta não procura o estabelecimento de sistema de freios e contrapesos para proteção da liberdade individual? Esta não busca dividir o exercício da soberania para alcançar o governo moderado? ${ }^{73}$

Em que pesem as grandes conquistas proporcionadas pela filosofia liberal ao longo do século XIX, especialmente vinculadas à liberdade individual, não se pode esquecer que a igualdade entre os indivíduos, meramente formal, e o absenteísmo do Estado Liberal, ao mesmo tempo em que proporcionaram a expansão do modo de produção capitalista, agravaram a situação social da classe trabalhadora, agora crescentemente urbana e sujeita a condições de vida miseráveis.

\footnotetext{
${ }^{71}$ SALDANHA, Nelson. O estado moderno e a separação de poderes. Saraiva: São Paulo, 1987, p. 101.

${ }^{72}$ FERREIRA FILHO, Manoel Gonçalves. Do processo legislativo. 7. ed. São Paulo: Saraiva, 2012, p. 119.

${ }^{73}$ FERREIRA FILHO, Manoel Gonçalves. Do processo legislativo. 7. ed. São Paulo: Saraiva, 2012, p. 119.
} 
Paulo Bonavides expõe os motivos pelos quais a exacerbação da liberdade individual e a igualdade meramente formal tornaram-se insuficientes para essa nova sociedade:

(...) aquela liberdade conduzia a graves e irreprimíveis situações de arbítrio. Expunha, no domínio econômico, os fracos à sanha dos poderosos. $\mathrm{O}$ triste capítulo da primeira fase da Revolução Industrial, de que foi palco o Ocidente, evidencia, com a liberdade do contrato, a desumana espoliação do trabalho, o doloroso emprego de métodos brutais de exploração econômica, a que nem a servidão medieval se poderia, com justiça, equiparar. ${ }^{74}$

Os problemas sociais e econômicos provocados pelo Estado Liberal, que vinham sendo revelados desde as Revoluções Industriais, iniciadas na Inglaterra ainda em meados do século XIX, ganharam uma dimensão ainda maior no início do século XX, seguindo-se vários outros acontecimentos política, econômica, social e juridicamente relevantes, em escala mundial, tais como a Revolução Russa de 1917, a Primeira Guerra Mundial de 1914-1918 e a Segunda Guerra Mundial de 1939-1945.

A derrota da Alemanha na Primeira Guerra Mundial, a Revolução Soviética de 1917 e os acontecimentos revolucionários germanos de 1918 foram os detonadores históricos para que o início da mutação do Estado no sentido social e material. A chamada "questão social", 75 iniciada principalmente a partir da segunda fase da Revolução Industrial, acabou por provocar enorme pressão nas estruturas estatais, exigindo do Executivo ações para transformação da realidade socioeconômica.

Em consequência disso, viu-se, pela primeira vez, a necessidade de regulação constitucional do campo dos direitos sociais e do setor intervencionista do Estado, surgindo o conceito de Constituição econômica. A Constituição de Weimar, de 1919, constitui uma referência imprescindível para o processo de positivação dos direitos sociais e para a própria institucionalização do Estado Social, o que se verificou também na Constituição Mexicana, de 1917.

Não obstante, o marco histórico que debilitou a ortodoxia liberal, partidária da não intervenção estatal, foi a intensa crise capitalista iniciada em 1929, que provocou massivo desemprego, crescentes tensões entre as classes sociais e a desconfiança na ideia liberal de

\footnotetext{
${ }^{74}$ BONAVIDES, Paulo. Do Estado Liberal ao Estado Social. 9. ed. São Paulo: Malheiros, 2009, p. 59.

75 Rubens Beçak esclarece que, por "questão social", entende-se "toda problemática, reflexo da Revolução Industrial, sobretudo da sua segunda fase, com profundas consequências na massa trabalhadora, amplamente desprotegida, então, em seus direitos fundamentais." BEÇAK, Rubens. A hipertrofia do Executivo brasileiro: impacto da Constituição de 1988. 2005. 184 p. Tese (Doutorado) - Faculdade de Direito, Universidade de São Paulo, São Paulo, 2005, p. 49, 62 e ss.
} 
que o equilíbrio econômico descansava na independência da oferta e da procura. Esses fatores deflagraram a necessidade de medidas políticas e econômicas com o fim de estabilizar o mercado e a sociedade.

Nas palavras do historiador Eric Hobsbawm, multiplicaram-se as ocasiões em que se tornava essencial que o governo governasse. ${ }^{76}$

Assim, logo no início do século XX, passou a ser bastante perceptível a crise dos Parlamentos, com enormes dificuldades para manutenção do princípio clássico da separação de poderes. O neoliberalismo, que correspondeu às reformas introduzidas no capitalismo a partir de 1929 e 1930, passou a admitir a presença maciça do Estado no processo econômico, revelando o processo de "hipertrofia do Executivo", principalmente verificado nos regimes totalitários de direita ou de esquerda. ${ }^{77}$

Nesse contexto, na transição do século XIX para o século XX, nasce o chamado Estado Social, em substituição ao já insuficiente Estado Liberal. Quanto a esse importante momento histórico (passagem do Estado Liberal para o Estado Social), mencione-se significativa passagem de Sérgio Resende de Barros: ${ }^{78,79}$

As revoluções operadas na superestrutura político-jurídica pelo liberalismo se conjugaram com as revoluções industriais na infraestrutura econômicosocial. Dessa conjuntura resultou o capitalismo selvagem, que gerou a Questão Social, termo com que a encíclica Rerum Novarum designa a convulsão social desencadeada nas cidades industriais do Ocidente, a partir de meados do século 19. (...) Por isso, a solução não era coletivizar a propriedade, mas controlar a ordem econômica, para assegurar (...) a igualdade social efetiva, material.

(...) o Estado foi chamado a intervir na ordem econômica e social, ou para substituir a ordem capitalista pela socialista, ou para moderar o capitalismo. Repele-se o ideal do laissez-faire, laissez passer, que le monde va de lui même, com o qual o liberalismo repelira o absolutismo.

No mesmo sentido, Carlos Ari Sundfeld afirma que o primordial objetivo do Estado Social, positivamente atuante, é o desenvolvimento (entendido como a elevação do nível

\footnotetext{
${ }^{76}$ HOBSBAWM, Eric. A Era dos Extremos: o breve século XX. São Paulo: Companhia das Letras, p. 217.

${ }^{77}$ SALDANHA, Nelson. O estado moderno e a separação de poderes. Saraiva: São Paulo, 1987, p. 104.

${ }^{78}$ BARROS, Sérgio Resende de. "Leis" autorizativas. Revista do Instituto de Pesquisas e Estudos. Divisão Jurídica, Bauru, n. 29, ago./nov. 2000, p. 260-261.

${ }^{79}$ Para aprofundamento sobre essa questão, cf. BONAVIDES, Paulo. Do Estado Liberal ao Estado Social. 9. ed. São Paulo: Malheiros, 2009.
} 
cultural e a mudança social), bem como a realização da justiça social (entendida como a extinção das injustiças na divisão do produto econômico). ${ }^{80}$

O Estado Social opôs-se ao liberalismo por meio da intervenção estatal na economia, planificando de forma indicativa os recursos públicos e privados, e por meio da busca pela realização da justiça social, prestando serviços e satisfazendo necessidades sociais. Pretendeuse a substituição da igualdade formal (do indivíduo perante a lei), corolário do Estado Liberal que apenas contribuiu para o aumento das distorções econômicas entre as classes populares, pela igualdade material, mediante tratamento desigual para as pessoas efetivamente desiguais, a fim de que pudessem desenvolver as oportunidades asseguradas, abstratamente, pela igualdade formal.

Nessa medida, com a nova dimensão assumida pelo Estado Social e suas políticas distributivas e interventoras, abandonou-se a noção clássica de lei e a ideia de primazia do Poder Legislativo sobre os demais Poderes constituídos. Concomitantemente, foi-se reforçando, cada vez com maior evidência, a necessidade de respostas rápidas por parte do Estado à população, o que somente poderia ser correspondido pelo Poder Executivo, por ser o Poder mais bem aparelhado e por ter maior capacidade resolutiva.

O Estado que resulta desse novo cenário é um Estado de serviços em que o Executivo tem suas funções ampliadas. Segundo Clèmerson Clève:

Falar de separação de poderes, agora, só guarda sentido quando está-se a referir aquele Estado de prestações constitucionalmente regulado... quer aceite esse ou aquele regime (parlamentarismo ou presidencialismo), cabe ao Executivo desempenhar a liderança política. Daí o seu relativo predomínio. ${ }^{81}$

O principal instrumento para imprimir a velocidade necessária às respostas demandadas pela sociedade, especialmente com relação aos chamados direitos sociais, ${ }^{82}$ foi a assunção, pelo Poder Executivo, da função legislativa, antes reservada ao Poder Legislativo.

Como bem assevera Rubens Beçak, ao analisar as origens do fenômeno da hipertrofia do Poder Executivo no Brasil, ratificando o entendimento pacificado na doutrina:

O século XX demonstrou que em todos os Estados do mundo, qualquer que seja o regime, o Executivo "furtou" do Legislativo sua tarefa institucional de origem, qual seja, a de legislar. ${ }^{83}$

\footnotetext{
${ }^{80}$ SUNDFELD, Carlos Ari. Fundamentos de Direito Público. 4. ed. São Paulo: Malheiros, 2006, p. 55.

${ }^{81}$ CLÈVE, Clèmerson Merlin. Atividade legislativa do Poder Executivo. 3. ed. São Paulo: RT, 2011, p. 42.

${ }^{82} \mathrm{Cf}$. nota de rodapé 55 .
} 
Rubens Beçak salienta que, apesar de os ordenamentos constitucionais expedidos a partir da segunda década do século XX já terem começado a expandir o campo de iniciativa específico do Poder Executivo (Constituição mexicana, de 1917, Constituição de Weimar, de 1919), é só a partir da década de 30, com destaque para o período do segundo pós-guerra, que a tendência de normatização pelo Executivo realmente se firmou no chamado Welfare State (Constituição francesa, de 1946, Lei Fundamental de Bonn, de 1949). ${ }^{84}$

Elucidativamente, confira-se trecho do discurso de posse de Franklin Delano Roosevelt, proferido em 04 de março de 1933, em que o eleito à Presidência dos Estados Unidos da América declara abertamente a necessidade de o Legislativo conferir maior amplitude para incursões legislativas do Executivo, com a finalidade de superar a crise socioeconômica:

Podemos esperar que o jogo normal dos poderes Executivo e Legislativo seja perfeitamente adequado para realizar a tarefa que nos cabe. Mas a exigência de uma ação urgente, sem precedentes, pode exigir o abandono temporário do jogo normal do procedimento público.

Estou disposto a propor, em virtude de meu dever constitucional, as medidas que uma nação ferida em um mundo ferido pode exigir. Essas medidas, assim como todas as outras que o Congresso, em sua sabedoria e experiência, vier a elaborar, eu tentarei, nos limites de meu poder constitucional, implementar rapidamente. Mas, se o perigo nacional tornar-se crítico, não me furtarei ao dever evidente que precisarei então enfrentar.

Solicito ao Congresso a única arma que resta para combater a crise, um amplo poder executivo para ganhar a guerra contra o perigo, um poder tão amplo quanto aquele que me seria concedido se nossa nação estivesse invadida por um exército inimigo. ${ }^{85}$

Não há dúvidas de que a passagem do Estado Liberal para o Estado Social, efetivamente instaurado a partir da década de 30 do século $\mathrm{XX}$, provocou gradativa transferência da função legislativa do Poder Legislativo para o Poder Executivo, subvertendo a ordem estabelecida pela clássica Teoria da Separação de Poderes de Montesquieu, segundo a qual a atividade legislativa deveria ser atribuída preferencialmente ao Poder Legislativo, e apenas instrumentalmente ao Executivo.

\footnotetext{
${ }^{83}$ Cf. BEÇAK, Rubens. A hipertrofia do Executivo brasileiro: impacto da Constituição de 1988. 2005.184 p. Tese (Doutorado) - Faculdade de Direito, Universidade de São Paulo, São Paulo, 2005, p. 43.

${ }^{84}$ Sobre o desenvolvimento da atribuição da função legislativa no âmbito do Poder Executivo, cf. FERREIRA FILHO, Manoel Gonçalves. A democracia no limiar do século XXI. São Paulo: Saraiva, 2001, p. 104-105.

${ }^{85}$ Texto original do discurso obtido na Biblioteca Virtual da Yale Law School, Lilian Goldman Law Library. ROOSEVELT, Franklin Delano. First Inaugural Address of Franklin D. Roosevelt. Disponível em: http://avalon.law.yale.edu/20th_century/froos1.asp. Acesso em: 08 jul. 2013.
} 
De fato, o desenvolvimento do Estado Social reverteu alguns dos postulados básicos do Estado Liberal, como a separação entre Estado e sociedade, e a própria pureza da separação dos Poderes estatais, carregando consigo o questionamento da liberdade negativa, já insuficiente, e a necessidade de uma liberdade positiva, participativa, segundo a qual o direito à igualdade se transformaria em um direito do indivíduo a se tornar igual nas condições de acesso à plena cidadania.

Como consequência, o Executivo sofreu uma grande expansão de suas funções, já que a ele cabia a realização da cidadania social, da forma mais célere possível. Coube ao Executivo ocupar o espaço deixado pelo Legislativo, apoplético, segundo Ferreira Filho. ${ }^{86}$

Ferreira Filho atribui a "queda" do Poder Legislativo ao advento das massas como força política e do sufrágio universal, que trouxe a divisão para dentro o seio das assembleias, onde antes só a burguesia tinha espaço e voz:

Essa divisão interna foi tanto mais grave quanto à mesma época se difundia $\mathrm{e}$ se acentuava a ideia de que o Estado deveria intervir no domínio econômico e social, por influência do "socialismo de cátedra", do "fabianismo", do "cristianismo social" etc.

De fato, na medida em que o Estado se imiscuía no domínio econômico e no domínio social, para proteger os economicamente fracos, os Parlamentos se viram cada vez mais impossibilitados de desempenhar as tarefas que dele eram esperadas.

Em síntese, Monica Herman Salem Caggiano explica a redução da atuação do Poder Legislativo nos seguintes termos:

A multiplicidade, a celeridade demandada, a especificidade das novas exigências da vida na comunidade social, demonstraram a inaptidão dos Parlamentos para, por intermédio de legislação própria, oferecer solução imediata aos problemas emergentes, impondo-lhes, inclusive, o acatamento às proposituras governamentais. ${ }^{87}$

Como se disse anteriormente, a decadência teve como contrapartida o engrandecimento do Executivo, o que fica evidente nas Constituições posteriores à Segunda Guerra Mundial, nas quais o antigo Executivo passou a ser visto como poder governamental.

\footnotetext{
${ }^{86}$ FERREIRA FILHO, Manoel Gonçalves. Do processo legislativo. 7. ed. São Paulo: Saraiva, 2012, p. 120.

${ }^{87}$ CAGGiANO, Monica Herman Salem. O Parlamento no cenário político do século XXI. Revista do Advogado, São Paulo, n. 73, p. 146-166, nov. 2003. (Estudo de Direito Constitucional em homenagem a Celso Ribeiro Bastos), p. 153. Note-se que a autora destaca o novo caráter de prestígio do Legislativo, referente ao controle político mediante exercício de função fiscalizatória.
} 
A principal manifestação de preponderância do Poder Executivo está na sua crescente interferência no processo legislativo. Esta verdadeira "usurpação" de funções originais de um Poder por outro Poder político, desfazendo a aparência estática da separação clássica de Montesquieu, também não passou incólume pelo Poder Judiciário.

Além do Executivo e do Legislativo, também o Judiciário sofreu certa modificação, se não em suas funções, na forma do exercício delas.

Isso porque o Direito assume uma função de dupla instrumentalidade: ainda cumpre a finalidade de organizar as situações que nascem do convívio da sociedade, fornecendo normas de regulação que traçam limites para a esfera individual de ação, mas também passa a servir à realização de objetivos de política social, com interferência naquelas situações sociais resultantes da esfera de autonomia concedida. ${ }^{88}$

Desse modo, abandonou-se o método mecanicista da aplicação da lei, por meio do qual se procedia à mera subsunção do fato à norma e à avaliação do certo ou errado perante a lei. Ao contrário, o juiz passou a examinar principalmente se o exercício discricionário do poder de legislar atendia à concretização dos resultados pretendidos pela lei. ${ }^{89}$

A ordem jurídica materializada no Estado Social passou a abranger alguns objetivos políticos e uma fundamentação em princípios. Com isso, pode-se afirmar, com fundamento nas ideias de Jürgen Habermas, que a argumentação jurídica se abriu para considerar argumentos morais, subjacentes aos princípios e argumentos orientados para fins. A generalidade e indeterminação das normas de princípio, e a sua peculiar densidade, passaram a obrigar o intérprete a uma atitude criativa frente ao caso concreto, levando em consideração a relação com todo o sistema normativo. ${ }^{90}$

Desse modo, e considerando-se o aumento do prestígio das normas constitucionais e o desenvolvimento do controle de constitucionalidade, vai o Poder Judiciário assumir papel de fiel da balança dos Poderes. Ou seja, com o desenvolvimento do controle de

\footnotetext{
${ }^{88}$ A esse respeito, cf. CLÈVE, Clèmerson Merlim. Atividade legislativa do Poder Executivo. 3. ed. São Paulo: RT, 2011, p. 58-59.

${ }^{89}$ FERRAZ JUNIOR. Tercio Sampaio. O Judiciário diante da divisão de poderes: um princípio em decadência? In: _. Direito Constitucional: liberdade de fumar, privacidade, estado, direitos humanos e outros temas. Barueri: Manole, 2007, p. 405.

${ }^{90}$ Cf. HABERMAS, Jürgen. Democracia e Direito: entre facticidade e validade. v. I. Tradução de Flávio Beno Siebeneichler. Rio de Janeiro: Tempo Brasileiro, 2003, p. 306.
} 
constitucionalidade, o Poder Judiciário vai imbuir-se do papel - mesmo que potencial - de convalidador (ou não) da vontade geral expressa na lei. ${ }^{91}$

Apesar da modificação funcional sofrida pelos Poderes, repita-se que o Poder Executivo destacou-se como o grande protagonista do chamado Estado Social vigente ao longo de todo o século XX. A necessidade de fortalecimento do Poder Executivo e de superação das mazelas socioeconômicas das camadas populares culminou na instauração dos regimes totalitários de direita, por exemplo, na Alemanha, na Itália, na Espanha e em Portugal, e de esquerda, como na extinta União Soviética.

Diante da sagração do autoritarismo durante o período inicial do que se chamou Estado Social, José Afonso da Silva alerta para a inexatidão dessa expressão. Ora, a Alemanha nazista, a Itália fascista, a Espanha franquista, Portugal salazarista e, especialmente, o Brasil, na Revolução de 1930, foram "Estados sociais”. A partir daí, conclui que o Estado de Direito, quer em sua forma Liberal, quer em sua forma Social, nem sempre foi um Estado Democrático. ${ }^{92,93}$

Somente a partir da queda dos regimes totalitários, especialmente após o final da Segunda Guerra Mundial, é que se pode falar na internacionalização dos direitos humanos e das primeiras tentativas de busca pela efetiva democracia formal e material nos países capitalistas ocidentais, do que decorreu uma necessária revisão do modelo de Estado Social. ${ }^{94}$

As atrozes violações aos direitos humanos que ocorreram durante a Segunda Guerra Mundial deflagraram subsequentemente ao seu encerramento, já em 1945, a criação da Organização das Nações Unidas, órgão internacional que, conforme o preâmbulo da Carta da Nações Unidas, tem por objetivo:

\footnotetext{
${ }^{91}$ Sobre o processo, detalhando a criação, evolução e alcance do controle de constitucionalidade, cf. ACOSTA SÁNCHEZ, José. Formación de la Constitución y Jurisdicción Constitucional. Madrid: Tecnos, 1998, p. 123126.

${ }^{92}$ SILVA, José Afonso da. Curso de Direito Constitucional Positivo. 35. ed. São Paulo: Malheiros, 2012, p. 115117.

${ }^{93}$ De fato, tomada a democracia segundo posta por Abraham Lincoln no discurso de Gettysburg de 1863 (governo do povo, para o povo e pelo povo), verifica-se que o Estado Liberal não podia ser considerado democrático, uma vez que ainda vigia o sistema eleitoral censitário, restringindo a participação política dos cidadãos. A universalização do voto foi uma vitória advinda apenas com os movimentos trabalhistas e socialistas, revelando uma das maiores conquistas dos Estados Constitucionais do século XX. Essa tentativa de conciliar o constitucionalismo com a democracia teve início, na Europa, tão somente com a Constituição alemã de Weimar, em 1919. Cf. BERCOVICI, Gilberto. O impasse da democracia representativa. In: ROCHA, Fernando Luiz Ximenes; MORAES, Filomeno (Org.). Direito Constitucional Contemporâneo: estudos em homenagem ao professor Paulo Bonavides. Belo Horizonte: Del Rey, 2005, p. 288-289.

${ }^{94}$ Merece destaque que, nos países de desenvolvimento tardio, como os da América Latina, a queda dos regimes totalitários e o consequente processo de democratização aconteceram também de forma tardia, a partir da década de 70 do século XX.
} 
(...) preservar as gerações vindouras do flagelo da guerra, que, por duas vezes no espaço da nossa vida, trouxe sofrimentos indizíveis à humanidade, e a reafirmar a fé nos direitos fundamentais do homem, na dignidade e no valor do ser humano, na igualdade de direitos dos homens e das mulheres, assim como das nações grandes e pequenas, e a estabelecer condições sob as quais a justiça e o respeito às obrigações decorrentes de tratados e de outras fontes de direito internacional possam ser mantidos, e a promover $\mathrm{o}$ progresso social e melhores condições de vida dentro de uma liberdade mais ampla.

E para tais fins praticar a tolerância e viver em paz uns com os outros, como bons vizinhos, unir nossas forças para manter a paz e a segurança internacionais, garantir, pela aceitação de princípios e a instituição de métodos, que a força armada não será usada a não ser no interesse comum, e empregar um mecanismo internacional para promover o progresso econômico e social de todos os povos. ${ }^{95}$

Inicialmente, a consecução desses fins se deu com a elaboração do projeto da chamada Declaração Universal dos Direitos do Homem, cujo texto foi aprovado pela Assembleia Geral das Nações Unidas em 10 de dezembro de 1948. Após, em 1966, essa Assembleia aprovou dois pactos: um sobre direitos civis e políticos, e outro sobre direitos econômicos, sociais e culturais.

No âmbito interno dos Estados, com o término da Segunda Grande Guerra e diante da expansão internacional dos direitos humanos, tornou-se imperativa a renovação constitucional, condizente com as novas demandas políticas e sociais. Inúmeros países elaboraram novas constituições e a afirmação dos direitos fundamentais era uma exigência da conjuntura, garantindo não apenas os direitos do homem, do cidadão, do trabalhador, como também permitindo e impondo intervenções econômicas, de forma a modelar ou remodelar instituições públicas ou privadas.

A marginalização da classe operária, provocada pelas Guerras Mundiais, causou, também, o surgimento de graves conflitos entre a classe operária e a burguesia, fazendo crescer no seio do operariado a necessidade de defesa de seus direitos políticos - o voto e a elegibilidade, até então sufocados pelo modelo do sistema eleitoral censitário.

Nessa medida, dentre os muitos direitos coroados pela Declaração Universal do Direito do Homem, não há dúvida de que, focalizando o cerne do princípio democrático, constaram entre eles os direitos políticos, o que foi recepcionado como direito fundamental em diversas das constituições promulgadas na segunda metade do século $\mathrm{XX}$, como a

95 Texto original da Carta das Nações Unidas, 26 de junho de 1945. Disponível em: $<$ http://unicrio.org.br/img/CartadaONU_VersoInternet.pdf $>$. Acesso em: 06 ago. 2013. 
Constituição de Portugal de 1976, a Constituição da Espanha de 1978 e a própria Constituição do Brasil de 1988.

Firmou-se o entendimento de que a democracia é o único regime político compatível com o pleno respeito aos direitos humanos. O regime democrático já não é, pois, uma opção política entre muitas outras, mas a única solução legítima para a organização do Estado.

Só se pode falar, portanto, em Estado Democrático de Direito a partir do exercício da soberania popular, o que se dá mediante a participação efetiva e operante do povo sobre a coisa pública, participação que não se exaure na simples formação das instituições representativas, pois este é apenas um estágio da evolução do Estado Democrático, cuja completude depende também da realização do princípio democrático como garantia geral dos direitos fundamentais da pessoa humana.

Nessa medida, percebe-se que o Estado Democrático de Direito surge como uma tentativa de corrigir falhas presentes no Estado Liberal e no Estado Social. É nesse sentido a lição do espanhol Elías Diaz, que cunhou a expressou "Estado Democrático de Direito":

(...) las insuficiencias del Estado liberal de Derecho, que han intentado corregirse muy parcialmente en el llamado Estado social de Derecho, parece que pueden encontrar su más coherente y completa superación en el que podemos denominar Estado democrático de Derecho. ${ }^{96}$

Na mesma linha, ao iniciar a explicação sobre a transição entre o Estado Social ao Estado Democrático de Direito, o autor afirma que o Estado Democrático de Direito aparece como real superação do Estado Social, significando o Estado de transição para o socialismo:

(...) el Estado democrático de Derecho aparece como la fórmula institucional en que actualmente, y sobre todo para un futuro próximo, puede llegar a concretarse el proceso de convergencia en que tal vez vayan concurriendo las diferentes concepciones actuales de la democracia y del socialismo. El paso del neocapitalismo al socialismo en los países de democracia liberal y, paralelamente, el creciente proceso de despersonalización e institucionalización jurídica del poder en los países de democracia popular constituye en síntesis la doble acción necesaria para ese proceso de convergencia en que aparecería el Estado democrático de Derecho. ${ }^{97}$

\footnotetext{
96 DÍAZ, Elías. Estado de derecho y sociedad democrática. Madrid: Taurus, 1998, p. 42. Em tradução livre: “(...) as insuficiências do Estado liberal de Direito, as quais se têm tentado corrigir muito parcialmente no chamado Estado social de Direito, parece que podem encontrar sua mais coerente e completa superação no que podemos denominar Estado democrático de Direito.”.

${ }^{97}$ DÍAZ, Elías. Estado de derecho y sociedad democrática. Madrid: Taurus, 1998, p. 136. Em tradução livre: “(...) o Estado democrático de Direito aparece como a fórmula institucional em que atualmente, e sobretudo para um futuro próximo, pode se concretizar o processo de convergência da democracia e do socialismo. O passo do neocapitalismo ao socialismo nos países de democracia liberal e, paralelamente, o crescente processo de
} 
Merece destaque a lição de Canotilho, que, remetendo também à formação de um Estado fundado do princípio democrático, ao contrário de Elíaz Dias, o denominou "Estado de direito democrático". Segundo o jurista português, o elemento democrático foi introduzido no Estado de Direito não apenas para limitar o poder (“to check the power”), mas também pela necessidade de legitimação desse poder ("to legitimize State power"), de modo que o Estado constitucional está assentado em dois pilares: (i) a legitimidade do direito, dos direitos fundamentais e do processo de legitimação no sistema jurídico, e (ii) a legitimidade de uma ordem de domínio e da legitimação do exercício do poder político. Com base nisso, Canotilho destaca a importância do princípio da soberania popular e justifica a denominação "Estado de direito democrático":

O Estado "impolítico" do Estado de Direito não dá resposta a esse último problema: donde vem o poder. Só o princípio da soberania popular segundo o qual "todo poder vem do povo" assegura e garante o direito à igual participação na formação democrática da vontade popular. Assim, o princípio da soberania popular concretizado segundo procedimentos juridicamente regulados serve de "charneira" entre o "Estado de direito" e o "Estado democrático" possibilitando a compreensão da moderna fórmula do Estado de direito democrático. ${ }^{98}$

Nesse sentido, e retomando a lição de José Afonso da Silva, referida anteriormente, o alerta do jurista foi precisamente o de que a igualdade pregada pelo Estado Liberal, fundada num elemento puramente formal e abstrato (isto é, a generalidade das leis), não tinha base material para se concretizar. A tentativa de corrigir isso, na doutrina do constitucionalista, foi a construção do Estado Social, que, no entanto, não conseguiu garantir a justiça social nem a efetiva participação democrática do povo no processo político.

Assim, o Estado Democrático de Direito, assentado nos pilares da democracia e dos direitos fundamentais, surge como uma forma de barrar a propagação de regimes totalitários que, adotando a forma de Estado Social, feriam as garantias individuais, maculando a efetiva participação popular nas decisões políticas.

No Estado Democrático de Direito coexistem harmonicamente o princípio da soberania popular, verificado através do regime democrático, e o princípio da legalidade,

despersonalização e institucionalização jurídica do poder nos países de democracia popular, constitui, em síntese, a dupla ação necessária para esse processo de convergência em que apareceria o Estado democrático de Direito.".

${ }_{98}$ CANOTILHO, José Joaquim Gomes. Direito Constitucional e Teoria da Constituição. 7. ed. Coimbra: Almedina, 2003, p. 100. 
herança do Estado Liberal. Logo, na busca de instaurar a plena incorporação do povo nos mecanismos de controle das decisões políticas, aplica-se, sob o crivo da legalidade, os ditames democráticos, garantindo, em sua plenitude, os direitos humanos fundamentais, inclusive aqueles de terceira geração, essencialmente prestacionais e coletivos.

Por essas razões, a conformação do Estado Contemporâneo, seguramente, trouxe consequências para o princípio da separação de Poderes, tendo em vista a mudança da natureza dos direitos sociais, a atribuição de novas funções ao Estado, como a garantia de direitos por meio de atuações positivas, e o enfraquecimento da separação entre Estado e sociedade.

Nesse sentido, segundo Nuno Piçarra, o princípio da separação de Poderes não é mero instrumento a serviço do primado da lei e do monismo do parlamento-legislador, mas um aparelho a serviço do controle e da limitação dos Poderes constituídos. Como destaca o jurista português, o Poder Judiciário, guardião dos direitos fundamentais, passa a ser visto como uma espécie de contrapeso ao Poder Legislativo e ao Poder Executivo, enquanto todos os três Poderes, na qualidade de Poderes constituídos, estão subordinados aos ditames constitucionais e, por isso, vinculados aos direitos fundamentais consagrados pela constituição. ${ }^{99}$

Portanto, em relação aos Poderes Legislativo e Executivo, o Poder Judiciário, guardião e defensor da efetivação dos direitos fundamentais e do princípio democracia, todos insculpidos como normas constitucionais, passa a ocupar posição de destaque no final do século XX e início do século XXI.

Isso porque, no pós-Segunda Guerra Mundial, não apenas o Legislativo continuou dando mostras da insuficiência no desempenho de sua função principal, a de legislar, mas também o Executivo deu mostras de desgaste pelas experiências autoritárias e totalitárias, assim como pela crise de financiamento do Estado de Bem-Estar.

Neste quadro de enfraquecimento dos Poderes Legislativo e Executivo e de revitalização do constitucionalismo, que enseja maior amplitude de interpretação das normas constitucionais pelos magistrados, é sintomático que as atenções estejam voltadas para o Poder Judiciário.

De fato, com a consolidação do Estado de Direito, no final do século XVIII, o papel do Poder Judiciário sofre uma drástica mudança, tendo em vista que quase todas as condutas

\footnotetext{
${ }^{99}$ PIÇARRA, Nuno. A separação dos poderes como doutrina e princípio constitucional: um contributo para o estudo das suas origens e evolução. Coimbra: Coimbra Editora, 1989, p. 196.
} 
humanas estavam encampadas dentro do espectro do Direito positivado, o que se deu por meio do uso de termos imprecisos e abstratos nos textos legais, manifestação da pretensão totalizante do Direito.

Em contrapartida, a imprecisão dos termos legais implicou na intangibilidade do “dever ser” pelo cidadão comum, reservando aos juristas e ao Judiciário, principalmente, resolver sobre a compreensão definitiva do conteúdo legal. Isso carreou ao Judiciário uma sobrecarga de trabalho e, concomitantemente, um maior ativismo judicial se fez presente. ${ }^{100}$

A importância do Judiciário foi acentuada pelo advento do Estado Social, na medida em que o Estado deixou de ser um ente omisso, tornando-se um ente ativo, intervencionista, de tal modo que, na omissão do Legislativo e do Executivo, os indivíduos podem incitá-lo por meio do Poder Judiciário. O Estado-juiz passa a ocupar um lugar de destaque na realização da justiça social do que decorre o aumento da demanda judicial evidenciando um conflito entre os Poderes praticamente inafastável.

Esse conflito torna-se mais evidente e mais acentuado em vista do controle de constitucionalidade - criação jurisprudencial norte-americana -, realizado pelo Poder Judiciário, mediante o qual os atos dos Poderes Legislativo e Executivo passam a ser submetidos ao crivo da Constituição, fazendo surgir a justiça constitucional.

Com o advento da sociedade industrial, já ao final do século XIX, seguido do fenômeno da "massificação"101 que atingiu o Judiciário, sobre ele recaiu a expectativa de que ofereça soluções tão drásticas quanto a intensidade dos problemas apresentados.

Nas palavras de Boaventura Sousa Santos, o Poder Judiciário passou a ser um "fiador da democracia” e, para isso, como bem observa Sálvio de Figueiredo Teixeira,

(...) não pode mais manter-se equidistante dos debates sociais, devendo assumir seu papel de participante dos destinos das nações, também responsável pelo bem comum, especialmente em temas como dignidade humana (...). Copartícipe, em suma, da construção de uma nova sociedade. $^{102}$

\footnotetext{
${ }^{100}$ CAPPELLETTI, Mauro. Juízes legisladores? Tradução de Carlos Alberto Álvaro de Oliveira. Porto Alegre: Sérgio Antonio Fabris, 1993, p. 22.

${ }^{101}$ CAPPELLETTI, Mauro. Juízes legisladores? Tradução de Carlos Alberto Álvaro de Oliveira. Porto Alegre: Sérgio Antonio Fabris, 1993, p. 22.

102 TEIXEIRA, Sálvio de Figueiredo. Compromisso com o direito e a justiça. Belo Horizonte: Del Rey, 2008, p. 143.
} 
André Ramos Tavares conclui que, no século XX, o Judiciário foi retirado da "posição secundária, submissa e quase clandestina, para uma de crucial relevância na manutenção da ordem social", como resultado do Estado Social, do Estado Liberal, da sociedade industrial e da viragem paradigmática do Direito. ${ }^{103}$

Assim, o século XX viu aumentarem as funções do Poder Judiciário com base em nos em alguns aportes doutrinários fundamentais tais como a doutrina da efetividade (ancorada na ideia de força normativa da Constituição, de Konrad Hesse ${ }^{104}$ ), a teoria dos princípios (enunciada por Robert Alexy ${ }^{105}$ e segundo a qual princípios e regras são normas constitucionais) e a noção de ordem objetiva de valores (consubstanciada na utilização da ponderação e da proporcionalidade para o desenvolvimento da criatividade jurisprudencial).

Referidos aportes teóricos serão analisados nos capítulos seguintes, já sob o ponto de vista de sua aplicação no Direito Constitucional brasileiro. Por ora, no que se refere ao contexto das novas funções do Poder Judiciário basta esclarecer que

Enquanto valores constitucionais, o sistema de direitos fundamentais, ao
mesmo tempo em que se constitui em núcleo básico do ordenamento
constitucional, também funciona como seu critério de interpretação. (...)
Ressalte-se que quando o constitucionalismo democrático se refere à
concretização da Constituição, mediante a ampliação do círculo de seus
intérpretes, busca, especialmente, garantir a efetividade do sistema de
direitos constitucionalmente assegurados.

No mesmo sentido, veja-se o conclusivo entendimento de Lewandowski acerca do protagonismo do Poder Judiciário no século XXI, especialmente devido à relevância dos direitos fundamentais na ordem constitucional contemporânea:

Então, este é o momento do Poder Judiciário. A era do direito a que se referia Bobbio é a era do Poder Judiciário. E a principal atribuição do Poder Judiciário, hoje, no século XXI, muito mais do que resolver problemas intersubjetivos, conflitos interindividuais, é ter o papel fundamental de dar concreção, dar efetividade aos direitos fundamentais, direitos estes compreendidos evidentemente em suas várias gerações, como patrimônio da humanidade.

$(\ldots)$

\footnotetext{
103 TAVARES, André Ramos. Manual do Poder Judiciário brasileiro. São Paulo: Saraiva, 2012, p. 27.

104 HESSE, Konrad. A força normativa da constituição. Traduzido por Gilmar Ferreira Mendes. In: Temas fundamentais de direito constitucional. Textos selecionados e traduzidos por Carlos dos Santos Almeida, Gilmar Ferreira Mendes e Inocêncio Mártires Coelho. São Paulo: Saraiva, 2009, p. 123-146.

105 ALEXY, Robert. Teoria dos direitos fundamentais. Tradução de Virgílio Afonso da Silva. São Paulo: Malheiros, 2008.

${ }^{106}$ CITTADINO, Gisele. Judicialização da política, constitucionalismo democrático e separação de poderes. In: VIANNA, Luiz Werneck (Org.). A democracia e os três poderes no Brasil. Belo Horizonte: UFMG, 2003, p. 31.
} 
Há um patrimônio de direitos que não cessa de evoluir e que foram conquistados ao longo dos séculos, cujo guardião e exatamente o Poder Judiciário. Por isso, afirmo que o grande protagonista do século XXI é o Poder Judiciário, e o Poder Judiciário precisa dar uma resposta célere às demandas que a sociedade lhe coloca, no que diz respeito à efetivação dos direitos fundamentais, e até porque a justiça que tarda é uma justiça falha.

$\mathrm{Na}$ era dos direitos, o grande protagonista é, sem dúvida nenhuma, o Poder Judiciário. Por isso, ao invés de "ativismo judicial" ou "ativismo do Supremo Tribunal Federal", prefiro utilizar a expressão "protagonismo" do Supremo Tribunal Federal e/ou, também, em conjunto, "protagonismo do Poder Judiciário", como um todo, neste limiar do século XXI. Por quê? Porque nós estamos entrando na era dos direitos. ${ }^{107}$

Não obstante, como contrapartida ao incremento das posições assumidas pelo Poder Judiciário e ao aumento de suas responsabilidades - e em virtude dos efeitos que suas decisões podem produzir no cotidiano social e político - segue-se uma preocupação intensa, traduzida em pretensões de fiscalização sobre a atuação dos magistrados, o que pode ser considerado natural se considerarmos o controle recíproco dos Poderes insere-se na própria teoria da separação.

Dentre outras, uma das principais críticas à proeminência do Poder Judiciário refere-se exatamente à violação ao princípio da separação de poderes, este tomado segundo à quase mítica interpretação da teoria de Montesquieu de inadmissão de qualquer interferência de um Poder sobre as funções dos outros.

Embora já se tenha dito que Montesquieu parece nunca ter pretendido uma separação absoluta dos Poderes, haja vista o reconhecimento de hipóteses de interferência entre eles, e que a própria História se encarregou de impor novas interpretações àquela teoria, certo é que, com olhar sobre a evolução do constitucionalismo e do modelo de Estado, é corrente na doutrina estrangeira e pátria a proposição de novas teorias de separação de Poderes, que se pretendem mais adequadas às atuais circunstâncias do Estado Democrático de Direito. ${ }^{108}$

\footnotetext{
${ }^{107}$ LEWANDOWSKI, Enrique Ricardo. O protagonismo do Poder Judiciário na era dos direitos. Revista de Direito Administrativo, n. 251, p. 77-85, mai/ago. 2009, p. 77-78.

${ }^{108}$ Nas palavras de Cezar Saldanha Souza Junior: “(...) a cada fase da divisão de poderes (vinculada, por sua vez, a uma fase própria da evolução do Estado), corresponde um tipo ideal de sistema de poderes, apto a embasar especificações adicionais." SOUZA JUNIOR, Cezar Saldanha. O tribunal constitucional como poder: uma nova teoria da divisão dos poderes. São Paulo: Memória Jurídica, 2002, p. 134.
} 
Com efeito, Marcello Caetano afirma que "o esquema da propriamente dita separação de poderes como forma de repartição de competências entre os diversos órgãos do Estado cada vez mais se afasta da realidade.”. ${ }^{109}$

Segundo Canotilho, a separação de poderes é um princípio organizatório-estrutural de repartição vertical (critério territorial - Federação/Estado Unitário - autonomias local e regional como expressões importantes da separação de poderes) e repartição horizontal (divisão das funções do poder soberano), que deve ser analisado à luz da Constituição positiva, pois a separação e interdependência não é um esquema constitucional rígido, mas apenas um "princípio organizatório fundamental" e, como tal, não há que perguntar pela sua realização estrita nem há que considerá-lo como um dogma de valor intemporal. O princípio da separação se articula e se combina com outros princípios constitucionais positivos. ${ }^{110}$

No mesmo sentido, André Ramos Tavares afirma que a atual teoria da separação de Poderes refere-se a uma "específica teoria acerca do arranjo institucional desenhado em cada Estado pela respectiva Constituição":

A doutrina da separação dos poderes, contudo, serve atualmente como uma técnica de arranjo da estrutura política do Estado, implicando a distribuição por diversos órgãos de forma não exclusiva, permitindo o controle recíproco, tendo em vista a manutenção das garantias individuais consagradas no decorrer do desenvolvimento humano. E é na Constituição que se encontra o grau de interdependência e colaboração entre os diferentes órgãos existentes e suas respectivas atribuições. ${ }^{111}$

O mesmo jurista tece crítica à pretensa necessidade de separação absoluta entre os Poderes e de uma teoria universalmente válida de separação de Poderes, o que, segundo ele, deve ser combatido:

A realidade, como se pode facilmente constatar, já se incumbiu de desmistificar a necessidade de poderes totalmente independentes, especialmente numa distribuição rígida tripartite. Ademais, a tese da absoluta separação entre os poderes os tornaria perniciosos e arbitrários (justamente aquilo que se pretende coibir). Como ponderou Nelson

\footnotetext{
109 “A contraposição entre os órgãos supremos do Estado, e especialmente entre governo e assembleia, encontrase hoje destituída de grande parte do seu alcance, no plano funcional, no da autoridade e até no do domínio prático da capacidade efetiva de tomar decisões políticas. O governo exerce em larga medida as mesmas funções que a assembleia e pratica atos com a mesma força vinculativa. As decisões políticas que o parlamento adota são efetivamente tomadas ou pelo governo ou pelos órgãos competentes dos partidos que compõe a maioria parlamentar e se encontram representados naquele. A ideia de limitação da soberania através da repartição das competências em que se desdobra por diversos órgãos perdeu, portanto, muito do seu valor." (CAETANO, Marcello. Manual de Ciência Política e Direito Constitucional. 6. ed. t. I. Lisboa: Almedina, 2006, p. 206.)

110 CANOTILHO, José Joaquim Gomes. Direito constitucional e teoria da constituição. 7. ed. Coimbra: Coimbra Editora, 2003, p. 555-557.

${ }^{111}$ TAVARES, André Ramos. Curso de direito constitucional. 8. ed. São Paulo: Saraiva, 2010, p. 1187.
} 
Saldanha: "Salta à vista o fato de que, nas Constituições de hoje - e sobretudo na prática política - a realidade do problema dos poderes não corresponde, senão em certa medida, ao esquema separativo engendrado pelos clássicos.". ${ }^{112}$

É também nessa linha a lição de Karl Loewenstein, que ressalta que a separação de poderes "es uma perfecta ilustración del pensar mecanicista", sendo que o princípio da necessária separação das funções estatais "ni es essencial para el ejercicio del poder político, ni presenta una verdad evidente y válida para todo tiempo", ${ }^{113}$ já que sua criação foi determinada pelas circunstâncias como um protesto ideológico do liberalismo político contra o absolutismo monárquico dos séculos XVII e XVIII.

Contudo, Loewenstein propugna por uma nova divisão tripartida: "la decisión política conformadora o fundamental (policy determination); la ejecución de la decisión (policy execution) y el control político (policy control)". ${ }^{114}$

Outros autores apresentam suas próprias categorias e classificações, identificando, de maneira fortemente subjetiva, esta ou aquela função. ${ }^{115}$

A constatação da existência de funções outras, atribuíveis a certos Poderes (órgãos de soberania) por insuficiência absoluta dos "poderes" tradicionalmente aceitos, pode-se dizer, é uma constante no pensamento mais recente de todos os que se ocuparam detidamente do tema, o que infirma a possibilidade de uma construção teórica das funções estatais.

No que tange à teoria montesquiana, a evidência do Poder Judiciário, hoje, é sentida de maneira bastante intensa - com exceção do modelo francês - servindo de base à necessária remodelagem da clássica teoria da separação dos poderes, no que se refere às relações entre estes. $^{116}$

\footnotetext{
${ }^{112}$ TAVARES, André Ramos. Curso de direito constitucional. 8. ed. São Paulo: Saraiva, 2010, p. 1187.

${ }^{113}$ LOEWENSTEIN, Karl. Teoría de la Constitución. 2. ed. Tradução de Alfredo Gallego Anabitarte. Barcelona: Ariel, 1976, p. 54-56.

${ }^{114}$ LOEWENSTEIN, Karl. Teoría de la Constitución. 2. ed. Tradução de Alfredo Gallego Anabitarte. Barcelona: Ariel, 1976, p. 62. Em tradução livre: "a decisão política conformadora ou fundamenta (determinação política); a execução da decisão (execução política) e o controle político (controle político)".

${ }^{115}$ Como exemplos emblemáticos, cite-se, nos Estados Unidos, Bruce Ackerman (ACKERMAN, Bruce. A nova separação dos Poderes. Rio de Janeiro: Lumen Juris, 2013), e, no Brasil, Cezar Saldanha Junior (SOUZA JUNIOR, Cezar Saldanha. O tribunal constitucional como poder: uma nova teoria da divisão dos poderes. São Paulo: Memória Jurídica, 2002).

${ }^{116}$ TAVARES, André Ramos. A superação da doutrina tripartite dos Poderes do Estado. Revista dos Tribunais, Cadernos de Direito Constitucional e Ciência Política, São Paulo, v. 29, out. 1999, p. 71.
} 
Diversos autores apresentam, nesse sentido, propostas de específicos arranjos institucionais, ou seja, desenhos constitucionais que consideram mais apropriados para o momento atual ou para suas circunstâncias históricas.

Relativamente ao constitucionalismo democrático, mencione-se, por exemplo, a proposta apresentada por Bruce Ackerman, respaldada na ideia de que a separação de Poderes deve se dar em nome da democracia, da eficiência de cada Poder, com suas características (seja em independência, seja em efetividade), assim como da proteção de direitos fundamentais. A fim de atender a essa finalidade, Ackerman propõe "múltiplos poderes". Isso porque seria insuficiente atribuir a cada poder uma determinada função sem que, vez ou outra, um acabe por exercer a prerrogativa que marcadamente seria de outro, mas que, uma vez realizada de maneira diferente, atende melhor à efetivação do princípio democrático e dos direitos fundamentais. ${ }^{117}$

Não se trata, pois, de uma teoria das funções do ponto de vista material, mas apenas uma proposta de reestruturação dos sistemas constitucionais no que tange ao relacionamento entre seus principais órgãos, sendo comum a vinculação a alguma concepção teórica como a promoção da democracia participativa ou da deliberativa, ou a melhor proteção dos direitos fundamentais.

O que se pretendeu demonstrar neste capítulo, portanto, foi a origem da Teoria de Separações de Poderes enunciada por Montesquieu, tendo em vista ter sido ela uma das bases do constitucionalismo moderno e base também de grande parte das novas propostas de organização das funções estatais. A partir da análise da evolução do Estado, desde a Revolução Francesa, também foi possível verificar que, a depender das circunstâncias sociais, econômicas e políticas, os Poderes Legislativo, Executivo ou Judiciário figuraram como protagonistas no cenário da organização estatal em diferentes momentos históricos.

Com suporte na apresentação desse quadro histórico de desenvolvimento da separação dos Poderes, passa-se a analisar, no âmbito do Estado Democrático de Direito brasileiro, a configuração dos Poderes, interessando-nos especialmente o Legislativo e o Judiciário, a partir da promulgação da Constituição de 1988, de forma a verificar, em momento posterior, os atuais impactos do Supremo Tribunal Federal sobre o equilíbrio entre esses dois Poderes.

${ }^{117}$ ACKERMAN, Bruce. A nova separação dos Poderes. Rio de Janeiro: Lumen Juris, 2013, p. 3. 


\section{OS PODERES LEGISLATIVO E JUDICIÁRIO NA CONSTITUIÇÃO DE 1988}

\subsection{Perspectiva histórica da separação de Poderes no Brasil}

Durante o período colonial (1530-1822), ${ }^{118}$ o Brasil não conheceu o sistema de separação de poderes. A rigor, as ideias do constitucionalismo e da separação de poderes, começaram a repercutir no Brasil em razão de desdobramentos da Revolução Liberal do Porto (inserida no contexto das Revoluções Liberais do século XVIII), iniciada em Portugal aos 24 de agosto de 1820, por meio da qual se exigia que o rei renunciasse a seus poderes absolutos e reivindicava a subordinação do rei a uma constituição, que deveria ser elaborada. A notícia da insurreição constitucionalista portuguesa logo chegou ao Brasil, onde juristas e letrados, ostensivamente apoiados por comerciantes e militares, passaram a exigir uma constituição que reproduzisse as linhas mestras da Constituição espanhola de $1812 .{ }^{119}$

Reunida a Assembleia Constituinte em 1823, a Constituição Política do Império do Brasil foi outorgada em 25 de março de 1824, inaugurando a primeira fase do constitucionalismo brasileiro ("constitucionalismo do Império"), com forte influência das ideias vigentes na Europa revolucionária, principalmente advindas da França e Inglaterra.

Nessa medida, a Constituição de 1824 instaurou um governo monárquico hereditário, constitucional e representativo $\left(\operatorname{artigo} 3^{\circ}\right)^{120,121}$ e, no que se refere à organização dos poderes, em seu artigo $10^{\circ}$, adotou a formulação tetrapartida de separação de poderes de Benjamin

\footnotetext{
${ }^{118}$ A partir de 1530, a Coroa Portuguesa implementou uma política colonizadora, inicialmente com as capitanias hereditárias, depois com o governo geral, instalado em 1548. As capitanias só foram extintas em 1759; o governo geral durou até 1808. Em 1808, a Corte Portuguesa transferiu-se para o Brasil, fugindo das tropas de Napoleão Bonaparte. O país tornou-se, em 1815, Reino Unido de Portugal, Brasil e Algarves. Em 1818, Dom João VI foi coroado rei. Três anos depois voltou para Portugal, deixando seu filho mais velho, Dom Pedro, como regente do país. Em 7 de setembro de 1822, Dom Pedro proclamou a Independência do Brasil. Para detalhes, cf. FAUSTO, Boris. História do Brasil. 12. ed. São Paulo: EDUSP, 2006.

${ }^{119}$ MORAES, Filomeno. As constituintes brasileiras: retrospectiva e tendência. DN Cultura, Fortaleza, n. 156, p. 4-5, 29. set. 1985 .

${ }^{120}$ Texto original da Constituição Política do Império do Brasil examinado a partir de CAMPANHOLE, Hilton Lobo; CAMPANHOLE, Adriano. Constituições do Brasil. 14. ed. São Paulo: Atlas, 2000, p. 789-845.

${ }^{121}$ Para aprofundamento acerca da história constitucional do Brasil, conferir História Constitucional do Brasil, obra paradigmática de Paulo Bonavides e Paes de Andrade. (BONAVIDES, Paulo; ANDRADE, Paes. História constitucional do Brasil. 8. ed. São Paulo: OAB Editora, 2006.)
} 
Constant, de modo que os poderes políticos constitucionalmente reconhecidos eram o Poder Legislativo, o Poder Moderador, o Poder Executivo e o Poder Judicial. ${ }^{122}$

O Poder Legislativo, eleito por votação indireta e censitária, era exercido pela assembleia geral, composta da câmara dos deputados, eletiva e temporária, e da câmara dos senadores, integrada por membros vitalícios nomeados pelo Imperador (artigos 13, 35, 40 e 43). O Poder Executivo, exercido pelos ministros de Estado, tinha como chefe o Imperador (artigo 102), e o Poder Judicial, independente, era composto de juízes e jurados (artigo 151). Por fim, o Poder Moderador era exercido, privativamente, pelo Imperador, como chefe supremo da nação e seu primeiro representante, para que zelasse pela manutenção da independência, equilíbrio e harmonia dos demais poderes políticos (artigo 98).

Importante destacar que, na estrutura concebida por Benjamin Constant, o Poder Moderador era idealizado como um poder neutro:

O Poder Executivo, o Poder Legislativo e o Poder Judiciário são três Poderes que devem cooperar, cada um por sua parte, para o movimento geral; mas, quando esses Poderes crescem desordenadamente, chocam-se entre si e se estorvam, é necessária uma força que lhes reduza a seu próprio lugar. Esta força não pode estar em um deles, porque servirá para destruir os demais. É preciso que esteja fora, que seja neutra, de certo modo, para que sua ação se aplique necessariamente onde quer que seja necessária sua aplicação e para que seja preservadora, reparadora, sem ser hostil. (...) A Monarquia constitucional cria este Poder neutro na pessoa do chefe do Estado. O interesse verdadeiro deste chefe não é de modo algum que um destes Poderes derrube o outro, mas que todos se apoiem, se estendam e obrem com acerto. ${ }^{123}$

No entanto, na teoria e na prática constitucional brasileira, o Poder Moderador nada tinha de neutro. Pelo contrário, era atuante, de tal modo que constituía um poder pessoal do Imperador, não apenas preservador e conservador dos outros, mas, sobretudo, controlador. Como destaca José Afonso da Silva, o Imperador "exercera o Poder Moderador com

\footnotetext{
${ }^{122}$ CONSTANT, Benjamin. Curso de política constitucional. Tradução de F. L. de Yturbe. Madri: Taurus, 1968, p. 14. A respeito da adoção da teoria de Benjamin Constant pela Constituição Imperial, João Camilo de Oliveira Torres, mesmo na condição de monarquista, consignou o seguinte: "O resultado prático foi uma espécie de desvirtuamento da doutrina de Constant, desvirtuamento imposto pelos fatos, de real utilidade, mas com seus inconvenientes. O certo é que o Imperador do Brasil não conseguia jamais, apesar de esforços, por vezes heroicos de D. Pedro II, ser aquela figura puramente neutra da teórica doutrina do publicista francês. Como os parlamentares não representavam autenticamente o corpo eleitoral e os gabinetes não eram expressão genuína da vontade nacional expressa em eleições, acabaram expressando a vontade nacional encarnada na pessoa do Imperador... O soberano, esta é a verdade, entrava demais nas questões políticas, por força das circunstâncias.". (TORRES, José Camilo de Oliveira. A democracia coroada. Petrópolis: Vozes, 1964, p. 145.)

${ }^{123}$ CONSTANT, Benjamin. Curso de política constitucional. Tradução de F. L. de Yturbe. Madri: Taurus, 1968, p. 258 .
} 
impressionante força ativa, interferindo na relação de Poderes não como mero árbitro, mas como um militante em posição de superioridade.”. ${ }^{24}$

A esse respeito, Paulo Bonavides destaca, inclusive, que a Constituição brasileira de 1824 foi a única, no mundo, que explicitamente aderiu à repartição tetradimensional de poderes, adotando o modelo de Benjamin Constant, "embora de modo mais quantitativo e formal do que qualitativo e material.". ${ }^{125}$

Em suma, pode-se dizer se tratou de uma constituição liberal quanto aos direitos individuais (pois, por influência da Declaração de Direitos do Homem e do Cidadão, o artigo 179 da Constituição trazia uma declaração de direitos individuais e de garantias), porém centralizadora e autoritária relativamente à soma de poderes conferidos ao monarca constitucional. $^{126}$

Com o advento da República, o Brasil ingressou na segunda fase de sua história constitucional, o "constitucionalismo da Primeira República". Nessa fase, os novos influxos constitucionais deslocaram o Brasil da zona de influência da Europa para a zona de influência dos Estados Unidos, ou seja,

(...) das Constituições francesas para a Constituição norte-americana, de Montesquieu para Jefferson e Washington, da Assembleia Nacional para a Constituinte da Filadélfia e depois da Suprema Corte de Marshall, e do peseudoparlamentarismo inglês para o presidencialismo americano. ${ }^{127}$

A Constituição da República dos Estados Unidos do Brasil, promulgada em 24 de fevereiro de 1891, adotou, embora de forma retardada relativamente aos Estados Unidos, a concepção política e doutrinária de um Estado liberal com todo o alcance dos valores republicanos, vigorando o que Paulo Bonavides resumiu como "um constitucionalismo de raízes norte-americanas com a fachada teórica quase perfeita do chamado Estado liberal de Direito.". 128

\footnotetext{
${ }^{124}$ SILVA, José Afonso da. O constitucionalismo brasileiro: evolução institucional. São Paulo: Malheiros, 2011, p. 359.

${ }_{125}$ BONAVIDES, Paulo. Curso de direito constitucional. 25. ed. São Paulo: Malheiros, 2010, p. 363.

${ }^{126}$ Sobre a "tropicalização" da teoria tetrapartida de Benjamin Constant no Brasil, é pertinente a observação de Itaboraí, repetida por José Afonso da Silva: "Aqui, o Rei reinava, governava e administrava, ao contrário, (...), ao contrário do sistema inglês, onde vigia a vige o princípio de que o Rei reina, mas não governa.". SILVA, José Afonso da. Curso de direito constitucional positivo. 36. ed. São Paulo: Malheiros, 2013, p. 76.

${ }^{127}$ BONAVIDES, Paulo. Curso de direito constitucional. 25. ed. São Paulo: Malheiros, 2010, p. 364.

${ }^{128}$ BONAVIDES, Paulo. Curso de direito constitucional. 25. ed. São Paulo: Malheiros, 2010, p. 365.
} 
Com efeito, segundo seu artigo $1^{\circ}$, a Nação Brasileira adotava como forma de governo a República Federativa, constituindo-se em Estados Unidos do Brasil, mediante a união perpétua e indissolúvel das suas antigas províncias, agora denominadas Estados.

O sistema de governo adotado foi o presidencialismo ao estilo norte-americano, optando-se pelo bicameralismo do Poder Legislativo (dividido entre a Câmara dos Deputados e o Senado Federal). Quanto à organização dos Poderes, a alteração mais relevante trazida pela Constituição de 1891 foi o abandono da divisão tetrapartida dos Poderes, vigente no Império, que foi substituída pela doutrina tripartida de Montesquieu, devidamente reajustada pelo sistema de freios e contrapesos (checks and balances). $\mathrm{O}$ artigo 15 estabelecia, assim, serem os "órgãos da soberania nacional o Poder Legislativo, o Executivo e o Judiciário, harmônicos e independentes entre si”. ${ }^{129}$

De modo geral, a organização estatal prevista pela Constituição de 1891, tal como sinteticamente descrita acima, vigorou até a edição do Decreto n. 19.398, de 11 de novembro de 1930, por meio do qual se instaurou no Brasil o Governo Provisório, fruto da chamada Revolução Liberal (liberal porque tinha como aspiração principal sanear o sistema representativo adulterado pelos vícios da corrupção eleitoral e estabelecer tanto quanto possível a autenticidade do processo eletivo). Esse Governo Provisório foi marcado pela concentração das funções dos Poderes Executivo e Legislativo na pessoa do então Presidente da República, Getúlio Vargas, e vigorou até 16 de julho de 1934, data da promulgação da segunda Constituição republicana.

Promulgada a segunda Constituição da República dos Estados Unidos do Brasil, iniciou-se a terceira fase do constitucionalismo brasileiro, o "constitucionalismo do Estado Social”, na qual se insere o profundo influxo do constitucionalismo alemão do século XX, consagrando um pensamento diferente em matéria de direitos fundamentais da pessoa humana, ou seja, ressaltando o aspecto social assinalado na Constituição de Weimar. ${ }^{130}$

Com efeito, a Constituição de 1934 marcou o advento do Estado Social no Brasil, sendo evidentes os avanços por ela trazidos, principalmente, em matéria eleitoral e trabalhista. $^{131}$

\footnotetext{
129 Texto original da Constituição de 1891 examinado a partir de CAMPANHOLE, Hilton Lobo; CAMPANHOLE, Adriano. Constituições do Brasil. 14. ed. São Paulo: Atlas, 2000, p. 727-783.

${ }^{130}$ BONAVIDES, Paulo. Curso de direito constitucional. 25. ed. São Paulo: Malheiros, 2010, p. 364.

131 Dentre outros, a Constituição instituiu o voto secreto e obrigatório para indivíduos a partir dos 18 anos, estendeu o direito de voto às mulheres (artigo 108), previu a criação das Justiças Eleitoral (artigo 82) e Trabalhista (artigo 122). Especificamente quanto aos direitos dos trabalhadores, foi uma Constituição bastante
} 
Quanto à conformação estatal, a Constituição de 1934 manteve da anterior os princípios formais fundamentais: a república, a federação, a divisão de poderes (Legislativo, Executivo e Judiciário, independentes e coordenados entre si), o presidencialismo e o regime representativo. Todavia, inovou em diversos aspectos. Quanto aos Poderes estatais, expandiu as funções do Poder Executivo, rompeu com o bicameralismo rígido do Poder Legislativo e criou a Justiça Eleitoral como órgão do Poder Judiciário. Ao lado da clássica declaração de direitos e garantias individuais (Título III, Capítulos I e II), adicionou um novo título sobre a ordem econômica e social (Título IV), e outro sobre a família, a educação e a cultura (Título V), com normas quase todas programáticas, sob a influência da Constituição alemã de Weimar.

Ainda em 1934, o então Presidente da República, Getúlio Vargas, diante da internalização no Brasil da problemática ideológica do pós-Primeira Guerra Mundial (confronto entre regimes ditatoriais de direita e de esquerda), dissolveu a Câmara dos Deputados e o Senado Federal, revogou a Constituição de 1934 e, posteriormente, em 10 de novembro de 1937, outorgou a Constituição dos Estados Unidos do Brasil, ${ }^{132}$ de cunho extremamente autoritário, tudo isso sob a suposta necessidade de "remédios de caráter radical e permanente" contra a "infiltração comunista". ${ }^{133,134}$

Em vista disso, a principal preocupação do Estado Novo, instaurado pelo Constituição de 1937 foi a de fortalecer o Poder Executivo, principalmente mediante o esvaziamento do Poder Legislativo. Ao Presidente da República foi atribuída a faculdade de, a qualquer momento, determinar o recesso do Parlamento Nacional, ocasião em que todas as funções desse órgão legislativo passavam às suas mãos. ${ }^{135}$

próspera, pois previu a fixação do salário mínimo, proibiu o trabalho infantil, limitou a jornada de trabalho a oito horas, proibiu a diferença de salário para um mesmo trabalho, por motivo de idade, sexo, nacionalidade ou estado civil, e instituiu o repouso semanal obrigatório, as férias remuneradas, a indenização para trabalhadores demitidos sem justa causa, a assistência médica e dentária, e a assistência remunerada a trabalhadoras grávidas. (Texto original da Constituição de 1934 examinado a partir de CAMPANHOLE, Hilton Lobo; CAMPANHOLE, Adriano. Constituições do Brasil. 14. ed. São Paulo: Atlas, 2000, p. 659-725.)

132 Texto original da Constituição de 1937 examinado a partir de CAMPANHOLE, Hilton Lobo; CAMPANHOLE, Adriano. Constituições do Brasil. 14. ed. São Paulo: Atlas, 2000, p. 573-658.

${ }^{133}$ CAMPANHOLE, Hilton Lobo; CAMPANHOLE, Adriano. Constituições do Brasil. 14. ed. São Paulo: Atlas, 2000 , p. 575.

${ }^{134}$ Em proclamação ao povo brasileiro, Getúlio Vargas fundamentou o golpe, dentre outros, da seguinte forma: "Por outro lado, as novas formações partidárias, surgidas em todo o mundo, por sua própria natureza refratária aos processos democráticos, oferecem perigo imediato para as instituições, exigindo, de maneira urgente e proporcional à virulência dos antagonismos, o reforço do poder central.". (SILVA, José Afonso da. Curso de direito constitucional positivo. 36. ed. São Paulo: Malheiros, 2013, p. 82.)

${ }^{135}$ E, com efeito, durante todo o Estado Novo, o Poder Legislativo esteve em recesso, como esclarece José Afonso da Silva: A Carta de 1937 não teve, porém, aplicação regular. Muitos de seus dispositivos permaneceram letra morta. Houve ditadura pura e simples, com todo o Poder Executivo e Legislativo concentrado nas mãos do 
Terminada a Segunda Guerra Mundial, em que o Brasil participou ao lado dos países Aliados contra Itália, Alemanha e Japão, logo teve início o movimento pela redemocratização brasileira, visando a uma reformulação constitucional, a exemplo do que vinha ocorrendo nos demais países afetados, direta ou indiretamente, pelas trágicas consequências da guerra.

Viabilizadas pelo golpe de Estado de 29 de outubro de 1945 (que introduziu outra fase de restauração do sistema representativo), em 02 de dezembro de 1945, foram realizadas eleições para a Presidência da República, Governo dos Estados, Parlamento e Assembleias Legislativas Estaduais, bem como para uma Assembleia Nacional Constituinte, instalada em 02 de fevereiro de 1946. Na Assembleia Constituinte, estavam representadas diversas correntes de opinião (direita, centro-democrático, progressista, socialista, porém, com predomínio da opinião conservadora) com os seguintes objetivos:

(...) assentar, com nitidez, sem artifícios, as fórmulas, os princípios cardeais do regime representativo, e estabelecer com precisão os rumos próprios à harmonia e independência dos poderes; a redução das possibilidades de hipertrofia do Poder Executivo; a conservação do equilíbrio político do Brasil, pelo regime de seus representantes no Senado e na Câmara; (...) a revisão do quadro esquemático da declaração de direitos e garantias individuais; o tratado, em contornos bem definidos, do campo econômico e social, onde se teriam de construir, em nome e por força da evolução e da justiça, os mais legítimos postulados constitucionais. ${ }^{136}$

A Constituição da República dos Estados Unidos do Brasil, promulgada sob esse sentimento, em 18 de setembro de 1946, teve como inspiração, ainda, a Constituição de Weimar. De fato, Paulo Bonavides, respaldado em Paulo Sarasate, observa que tanto a Constituição de 1934, quanto a de 1946 teve influxo do constitucionalismo alemão, marcadamente social. ${ }^{137}$

Embora essa nova constituição tenha continuado a contribuir para o desenvolvimento dos direitos fundamentais sociais, a organização dos Poderes não sofreu grandes alterações relativamente à Constituição de 1934, mantendo no artigo 36 a disposição segundo a qual "são Poderes da União o Legislativo, o Executivo e o Judiciário, independentes e harmônicos entre si.". 138

Presidente da República, que legislava por via de decretos-leis que ele próprio aplicava, como órgão do Executivo. SILVA, José Afonso da. Curso de direito constitucional positivo. 36. ed. São Paulo: Malheiros, 2013, p. 83.

${ }^{136}$ SILVA, José Afonso da. Curso de direito constitucional positivo. 36. ed. São Paulo: Malheiros, 2013, p. 85.

${ }^{137}$ BONAVIDES, Paulo. Curso de direito constitucional. 25. ed. São Paulo: Malheiros, 2010, p. 369.

138 Texto original da Constituição de 1946 examinado a partir de CAMPANHOLE, Hilton Lobo; CAMPANHOLE, Adriano. Constituições do Brasil. 14. ed. São Paulo: Atlas, 2000, p. 449-524. 
A Constituição de 1946 vigorou até 9 de abril de 1964, ocasião em que tiveram início os Atos Institucionais do regime militar autoritário, instaurado mediante o golpe de $1^{\circ}$ de abril de 1964, em função da instabilidade do governo e da consequente queda do então Presidente da República, João Goulart.

Em 24 de janeiro de 1967, foi elaborada a Constituição do Brasil (posteriormente denominada Constituição da República Federativa do Brasil, pela Emenda Constitucional n. 1, de 17 de outubro de 1969), a qual buscou institucionalizar e legalizar o regime militar, aumentando a influência do Poder Executivo sobre o Legislativo e o Judiciário, e criando desta forma, uma hierarquia constitucional centralizadora. As emendas constitucionais, que eram atribuições do Poder Legislativo, com o aval do Poder Executivo e Judiciário, passaram a ser iniciativas únicas e exclusivas do Chefe do Poder Executivo, ficando os demais Poderes relegados a meros espectadores das aprovações dos pacotes, como seriam posteriormente nominadas as emendas e legislações baixadas pelo Presidente da República.

O regime que se consolidou no Brasil, a partir de 1968 promoveu inédita centralização de poderes no Executivo, deixando o Legislativo à margem da formulação, decisão ou implementação da política nacional. Embora o Congresso tenha se mantido em funcionamento durante alguns períodos ao longo do regime militar, a situação se empenhava em criar uma ideologia, quando não sobre sua inutilidade, pelo menos sobre a impossibilidade de o Congresso Nacional ser agente capaz de promover ou facilitar o processo de desenvolvimento. ${ }^{139}$

O enfraquecimento do Poder Legislativo, iniciado a partir de abril de 1964, chegou ao ápice com a edição do Ato Institucional n. 5, de 13 de dezembro de 1968, e da Emenda Constitucional n. 1, de 17 de outubro de 1969, ("teórica e tecnicamente, não se tratou de emenda, mas de nova constituição", conforme ensinamento de José Afonso da Silva, ${ }^{140}$ compartilhado pela doutrina majoritária e pelo próprio Supremo Tribunal Federal).

\footnotetext{
139 “Assim, diferentemente dos autoritarismos dos países vizinhos que, via de regra, não suportavam a existência da instituição legislativa, no Brasil o comportamento utilizado pelas forças que se assenhorearam do poder a partir de 1964 foi debilitar o Congresso através de sucessivas depurações nos seus quadros, de maneira a extinguir qualquer oposição ao projeto autoritário em implantação; coibir a emergência de novos quadros desviantes; extorquir a sua capacidade de legislar autonomamente ou de exercer efetiva função fiscalizadora; extinguir qualquer prerrogativa importante dos parlamentares.”. MORAES, Filomeno. O Poder Legislativo na nova Constituição. Revista da Procuradoria Geral do Estado do Ceará, Fortaleza, n. 7, p. 42-45, 1990, p. 44.

${ }^{140}$ SILVA, José Afonso da. Curso de direito constitucional positivo. 36. ed. São Paulo: Malheiros, 2013 , p. 87.
} 
O Ato Institucional n. 5 representou o auge da intervenção do Poder Executivo nas esferas de atribuições do Poder Legislativo e do Poder Judiciário, além de ter viabilizado a supressão de diversos direitos individuais. ${ }^{141,142}$

No entanto, a emergência, nos anos 70, dos movimentos de defesa dos direitos humanos (especialmente dos direitos relativos à vida e à integridade física daqueles que lutavam contra o regime militar autoritário que se abateu sobre o país), assim como a luta, na primeira metade da década de 80 , pela reconquista dos direitos de participação política, implicaram no clamor pela normalização democrática e pela conquista do Estado Democrático de Direito.

A eleição de Tancredo Neves para a Presidência da República, em 1985, deu início ao processo de redemocratização no Brasil, que culminou com a promulgação da Constituição da República Federativa do Brasil aos 5 de outubro de 1988.

Já em 28 de junho de 1985, o Presidente José Sarney enviou mensagem ao Congresso Nacional com a proposta de convocação de uma Assembleia Nacional Constituinte. Aprovada, a Assembleia Nacional Constituinte foi convocada por meio da Emenda Constitucional n. 26, de 27 de novembro de 1985, e instalada no Congresso Nacional em $1^{\circ}$ de fevereiro de 1987.

\footnotetext{
${ }^{141} \mathrm{O}$ seu artigo $2^{\circ}$ dispunha que o Presidente da República podia decretar o recesso do Congresso Nacional, das Assembléias Legislativas e das Câmaras de Vereadores, que só voltariam a funcionar quando o Presidente os convocasse. Durante o recesso, o Poder Executivo Federal, Estadual ou Municipal cumpriria as funções do Legislativo correspondente. $\mathrm{O}$ artigo 11 dispunha que o Poder Judiciário também se subordinava ao Executivo, na medida em que os atos praticados de acordo com o Ato Institucional n. 5 e seus Atos Complementares excluiam-se de qualquer apreciação judicial, e o artigo 10 suspendia a garantia de habeas corpus, nos casos de crimes políticos, contra a segurança nacional, a ordem econômica e social e a economia popular. Além disso, segundo o artigo $3^{\circ}$, o Presidente da República podia decretar a intervenção nos Estados e Municípios, "sem as limitações previstas na Constituição" e, conforme o artigo $4^{\circ}$, ouvido o Conselho de Segurança Nacional, novamente "sem as limitações previstas na Constituição", podia suspender os direitos políticos de quaisquer cidadãos por 10 anos e cassar mandatos eletivos federais, estaduais e municipais. O Presidente da República podia também, conforme o artigo $8^{\circ}$, decretar o confisco de bens em decorrência de enriquecimento ilícito no exercício de cargo ou função pública, após a devida investigação - com cláusula de restituição se provada a legitimidade da aquisição dos bens. (Texto original do Ato Institucional n. 5, de 13 de dezembro de 1968, examinado a partir de CAMPANHOLE, Hilton Lobo; CAMPANHOLE, Adriano. Constituições do Brasil. 14. ed. São Paulo: Atlas, 2000, p. 422-424.)

${ }^{142}$ Nessa medida, José Afonso apresenta breve retrato da preponderância absoluta do Poder Executivo durante o período do regime militar, fundamentada no princípio da segurança nacional: “(...) o princípio da segurança nacional se tornou verdadeira norma fundamental do sistema constitucional então vigente, espécie de princípio de necessidade. Doutrina global que dominou toda a estrutura do Estado e de seus Poderes, com enfraquecimento de poder democrático e consequente fortalecimento do Poder Executivo. O Poder Executivo, exercido pelo Presidente da República, era o único Poder efetivo que vigorava no País, porque o Poder Legislativo ficou acuado. O STF, com uma plêiade de ministros da mais alta dignidade, tentou resistir, mas num certo momento sofreu a interferência violenta do Poder Executivo, que aposentou seus homens mais conscientes e os substituiu por outros que the prestassem vassalagem.". (SILVA, José Afonso da. O constitucionalismo brasileiro: evolução institucional. São Paulo: Malheiros, 2011, p. 377.)
} 
Com a conclusão dos trabalhos constituintes, em 22 de setembro de 1988 (quando foi votado, em turno único, o texto final da Constituição), seguiu-se a sua promulgação, aos 5 de outubro de 1988, historicamente marcada pelo discurso do deputado Ulysses Guimarães, presidente da Assembleia Nacional Constituinte, que destacou sua origem democrática e sua vocação à efetivação da cidadania.

A partir de 1988, portanto, o Brasil ganhou uma Constituição com forte vocação democrática, tendente à plena concretização de suas normas. E é com base nessa vocação que deve ser compreendida a organização dos Poderes estatais, como se verá a seguir.

\subsection{A separação de Poderes na Constituição de 1988}

A Constituição da República Federativa do Brasil instaurou no Brasil o Estado Democrático de Direito (artigo $1^{\circ}$, caput), o qual tem como fundamentos a soberania, a cidadania, a dignidade da pessoa humana, os valores sociais do trabalho e da livre iniciativa e o pluralismo político (artigo $1^{\circ}$, incisos I a V), e, como objetivos fundamentais, a construção de uma sociedade livre, justa e solidária; a garantia do desenvolvimento nacional; a erradicação da pobreza e da marginalização, a redução das desigualdades sociais e regionais; e a promoção do bem de todos, sem preconceitos de origem, raça, sexo, cor, idade e quaisquer outras formas de discriminação (artigo $3^{\circ}$ ).

Como se verifica, a Constituição de 1988, denominada por Ulysses Guimarães "Constituição Cidadã "143 erigiu-se precipuamente sobre a garantia dos direitos fundamentais aos cidadãos, direitos fundamentais estes que, além de poderem ser encontrados de forma esparsa no texto constitucional, estão concentrados nos artigos $5^{\circ}$ e $6^{\circ}$ do Título II - Dos Direitos e Garantias fundamentais.

A inscrição dos valores e objetivos da República Federativa do Brasil, visivelmente inspirados na defesa e garantia dos direitos fundamentais - seja pelo anseio ao desenvolvimento social ou econômico - assim como a farta inscrição dos direitos

\footnotetext{
${ }^{143}$ Ulysses Guimarães, Presidente da Assembleia Constituinte, declarou promulgada a Constituição de 1988 por meio de discurso realizado em 05 de outubro de 1988 diante da Assembleia Nacional Constituinte, clamando-a como uma "constituição cidadã".
} 
fundamentais e dos instrumentos para sua garantia no texto constitucional, advém, como se disse, da reação ao período ditatorial vigente no País entre 1964 e 1985. Desse modo, o constitucionalismo democrático brasileiro buscou inspiração nas Constituições portuguesa, de 1976, e espanhola, de 1978, uma vez que, assim como o Brasil, Portugal e Espanha atravessaram longos períodos de autoritarismo político, tendo elaborado, por isso, constituições com vistas à implementação e consolidação de regimes democráticos.

Quanto aos direitos fundamentais, Paulo Bonavides destaca também a influência da doutrina alemã sobre a Constituição de 1988, no que se refere à proeminência dos direitos fundamentais. ${ }^{144}$

Com efeito, o sistema de direitos fundamentais se converteu no núcleo básico do ordenamento constitucional brasileiro, tanto assim que o rol de direitos e garantias individuais foi topograficamente realocado na Constituição, que o inseriu já no artigo $5^{\circ}$ (até 1988, a tradição do Direito Constitucional brasileiro era inscrever essas normas na parte final da Constituição).

Nesse contexto, a separação de Poderes deve ser entendida como pressuposto fundamental para a adequada manutenção da garantia dos direitos fundamentais, o que se dá por meio do controle recíproco entre os Poderes constituídos, prevenindo a sobreposição e domínio de um deles sobre os demais.

O princípio da separação de Poderes está previsto no artigo $2^{\circ}$ da Constituição de 1988 ("São Poderes da União, independentes e harmônicos entre si, o Legislativo, o Executivo e o Judiciário.”) e, ao lado da forma federativa de Estado, do voto direto, secreto, universal e periódico, e dos direitos e garantias fundamentais, foi alçado à categoria de cláusula pétrea do ordenamento jurídico brasileiro, conforme o artigo $60, \S 4^{\circ}$.

Isso significa dizer que as previsões acima não podem ser alteradas, nem mesmo por Emenda Constitucional, constituindo-se em limitações materiais ao poder de reforma da Constituição do Estado brasileiro. Sem a garantia dessas condições mínimas, o Estado Democrático de Direito não pode subsistir, correndo-se o risco de retorno a regimes

\footnotetext{
${ }^{144} \mathrm{Na}$ técnica, na forma e na substância da matéria pertinente a direitos fundamentais, a derradeira Constituição do Brasil se acerca da Lei Fundamenal alemã de 1949, e até a ultrapassa em alguns pontos. Segue e incorpora também a mesma tradição de Weimar em dar proeminência ao social. Com efeito, não é possível compreender o constitucionalismo do Estado Social brasileiro contido na Carta de 1988 se fecharmos os olhos à teoria dos direitos sociais fundamentais, ao princípio da igualdade, aos institutos processuais que garantem aqueles direitos e aquela liberdade e ao papel que doravante assume na guarda da Constituição o Supremo Tribunal Federal. (BONAVIDES, Paulo. Curso de direito constitucional. 25. ed. São Paulo: Malheiros, 2010, p. 369-373.)
} 
autoritários e até mesmo totalitários, como aquele experimentado nas décadas anteriores à promulgação da Constituição de 1988, em que, na prática, houve absoluta concentração de funções no Poder Executivo. ${ }^{145}$

Dessa forma, no quadro brasileiro de distribuição das funções aos Poderes, a Constituição de 1988, além de consagrar expressamente o princípio da separação tripartite dos Poderes em seu artigo $2^{\circ}$, estruturou um sistema de sistema de freios e contrapesos ao longo de seu texto, para viabilizar o controle interorgânico entre eles.

Ao prever funções atípicas a cada um dos Poderes, distintas das suas funções típicas, a Constituição de 1988 impôs uma interpretação menos rígida da Teoria da Separação de Poderes de Montesquieu e mais adequada às particularidades do Estado contemporâneo, conforme Inocêncio Mártires Coelho:

Inicialmente formulado em sentido forte - até porque assim o exigiam as circunstâncias históricas - o princípio da separação dos poderes, nos dias atuais, para ser compreendido de modo constitucionalmente adequado, exige temperamentos e ajustes à luz das diferentes realidades constitucionais, num círculo hermenêutico em que a teoria da constituição e a experiência constitucional mutuamente se completam, se esclareçam e se fecundam.

Nesse contexto de modernização, esse velho dogma da sabedoria política teve de flexibilizar-se diante da necessidade imperiosa de ceder espaço para a legislação emanada do Poder Executivo [...] bem assim para a legislação judicial, fruto da inevitável criatividade de juízes e tribunais [...]. ${ }^{166,147}$

Com efeito, foram inseridas no texto constitucional diversas mitigações ao que Anna Cândida da Cunha Ferraz chamou de "cláusulas-parâmetro" do princípio da tripartição funcional do Poder político estatal, a saber, (i) a independência e harmonia entre os Poderes,

\footnotetext{
145 Apesar da recente experiência autoritária militar e da justificada desconfiança com relação ao Poder Executivo, José Afonso da Silva afirmar que “(...) o equilíbrio de Poderes não está no enfraquecimento do Executivo, tirando dele o que só a ele deve corresponder. Está no aparelhamento do Legislativo para o exercício de suas funções com eficiência e presteza (...), pois um Estado forte tem que ter instituições governamentais igualmente fortes: Legislativo e Executivo, mas também um Judiciário dotado de condições para o exercício de suas funções." (SILVA, José Afonso da. O constitucionalismo brasileiro: evolução institucional. São Paulo: Malheiros, 2011, p. 377.)

${ }^{146}$ MENDES, Gilmar Ferreira; BRANCO, Paulo Gustavo Gonet. Curso de direito constitucional. 8. ed. São Paulo: Saraiva, 2013, p. 220.

${ }^{147}$ Outrossim, destaque-se a lição de Ferreira Filho, que ratifica a existência de funções exercidas pelos Poderes diversas das típicas, apesar de entender que a diferença de funções nem sempre é tão grande, conforme o trecho a seguir: "Em realidade, essa tripartição não tem o rigor necessário para ser acatada como científica. De fato, é fácil mostrar que as funções administrativa e jurisdicional têm no fundo a mesma essência, que é a aplicação da lei a casos particulares. A distinção entre ambas pode estar no modo, no acidental, portanto, já que substancialmente não existe. Por outro lado, a função legislativa não esgota a edição de regras gerais e impessoais. Tradicionalmente, inclui-se na função administrativa o estabelecimento de regulamentos, cujo conteúdo são também regras gerais e impessoais." (FERREIRA FILHO, Manoel Gonçalves. Curso de direito constitucional. 36. ed. São Paulo: Saraiva, 2010, p. 162-163.).
} 
(ii) a indelegabilidade de poderes e (iii) a inacumulabilidade de funções de Poderes distintos. $^{148}$ A necessidade de atribuição expressa a outros Poderes das funções originariamente exercidas com exclusividade pelos outros (ou seja, da assunção efetiva do sistema de freios e contrapesos) decorreu das inevitáveis transformações que se operaram no concerto das atribuições do Estado, visando a lhe conferir maior agilidade e eficiência na solução das graves questões político-econômico-sociais da atualidade, tais quais a pobreza e o desenvolvimento econômico.

O abrandamento das referidas "cláusulas-parâmetro" pode ser verificado por meio de diversas normas esparsas da Constituição de 1988, nas quais se revela a inserção de atividades essenciais do Poder Legislativo nas esferas de competência do Executivo e do Judiciário; de atividades essenciais do Poder Executivo nas esferas de competência do Legislativo e do Judiciário; e de atividades do Poder Judiciário nas esferas de competência do Legislativo e do Executivo. Com base nessa estruturação difusa dos freios e contrapesos, André Ramos Tavares conclui que apenas por meio de um estudo sistemático é possível chegar a alguma conclusão sobre as funções que cada órgão exerce, não sendo estas restritas a três, existindo também a função administrativa, a governativa ou política, a judicial, a legislativa, a de controle, entre outras. ${ }^{149}$

Sobre a sistemática constitucional da distribuição das funções estatais, Anna Cândida da Cunha Ferraz elucida:

(...) no desdobramento constitucional do esquema de poderes, haverá um mínimo e um máximo de independência de cada órgão de poder, sob pena de se desfigurar a separação, e haverá, também, um número mínimo e um máximo de instrumentos que favoreçam o exercício harmônico dos poderes, sob pena de, inexistindo limites, um poder se sobrepor ao outro poder, ao invés de, entre eles, se formar uma atuação 'de concerto'. ${ }^{150}$

Fica claro, portanto, que o legislador constituinte, quando do arranjo das funções estatais, visou a uma separação relativa dos Poderes, almejando, por meio de um jogo de influências e inter-relações dos órgãos estatais, uma maior coordenação entre eles, com a

\footnotetext{
${ }^{148}$ Segundo Anna Cândida da Cunha Ferraz, há três cláusulas-parâmetro que usualmente informam a aplicação do princípio da separação dos Poderes: a independência e a harmonia entre os Poderes, a indelegabilidade de poderes e a inacumulabilidade de funções de Poderes distintos (FERRAZ, Anna Cândida da Cunha. Conflito entre Poderes: o poder congressual de sustar atos normativos do Poder Executivo. São Paulo: Revista dos Tribunais, 1994, p. 13-14).

${ }^{149}$ TAVARES, André Ramos. Curso de direito constitucional. 8. ed. São Paulo: Saraiva, 2010, p. 1189.

${ }^{150}$ FERRAZ, Anna Cândida da Cunha. Conflito entre Poderes: o poder congressual de sustar atos normativos do Poder Executivo. São Paulo: Revista dos Tribunais, 1994, p. 14.
} 
finalidade precípua de aumentar a eficiência do Estado na execução das várias tarefas a seu cargo, e, com isso, a um só tempo, proteger a esfera jurídica dos indivíduos e realizar o interesse público. ${ }^{151}$

Em outras palavras, muito embora a organização das funções do Estado não esteja disposta segundo uma rigorosa divisão material de atribuições (afinal, o Legislativo administra e julga, o Executivo julga e legisla, e o Judiciário legisla e administra), a Constituição, quando do tratamento dos controles interorgânicos, esquematizou as competências de maneira a otimizar as tarefas estatais e assegurar uma atuação orgânica comprometida e alinhada com seus ditames.

Nessa medida, Canotilho sustenta que a separação funcional das funções do Estado deve ser entendida como "ordenação controlante-cooperante de funções", uma vez que, no Estado Constitucional de Direito, não é tão importante distinguir se o ato do legislador, do governo ou do juiz é legislativo, executivo ou jurisdicional. O que realmente importa é se os atos de cada um deles podem ser feitos e se são feitos de forma legítima. ${ }^{152}$

Havendo sempre um órgão titular de uma dada função, a Constituição não tolera que um Poder, ao exercer atividade atípica, esvazie o campo funcional reservado a outro. Isso graças à existência de um órgão (contrapeso) competente para fiscalizar e controlar sancionando-se, se for o caso - o comportamento viciado do outro, evitando-se, assim, uma “deslocação do peso funcional dos órgãos estatais”. 153

Visando a viabilizar um exercício mais eficaz e justo das funções públicas, o legislador constituinte brasileiro, atento às transformações havidas na estrutura orgânicofuncional dos Estados contemporâneos, teve a preocupação de plasmar no texto constitucional uma distribuição funcional do Poder em razão da estrutura e do processo próprio a cada órgão estatal. Ou seja, os órgãos receberam as funções que teriam mais capacidade para desempenhar, o que permite afirmar ser a separação de Poderes um "princípio organizatório estruturante de uma organização racional dos Poderes do Estado", nas palavras de Jorge Reis Novais. ${ }^{154}$

\footnotetext{
151 TEIXEIRA, José Horácio Meirelles. Curso de direito constitucional. 2. ed. Atualizado por Maria Garcia. São Paulo: Conceito, 2011, p. 590-591.

${ }^{152}$ CANOTILHO, José Joaquim Gomes. Direito constitucional e teoria da constituição. 7. ed. Coimbra: Almedina, 2007, p. 245.

${ }^{153}$ CANOTILHO, José Joaquim Gomes. Direito constitucional e teoria da constituição. 7. ed. Coimbra: Almedina, 2007, p. 502.

${ }^{154}$ NOVAIS, Jorge Reis. Separação de Poderes e limites da competência legislativa da assembleia da República. Lisboa: Lex, 1997, p. 37.
} 
A estrutura orgânico-funcional do Estado, orientada pelo que Canotilho denominou "esquema organizatório funcionalmente adequado", ${ }^{155}$ aponta claramente para uma dupla dimensão do princípio da separação dos Poderes: ${ }^{156}$ uma negativa, tradicional, como técnica de contenção do poder político; outra positiva, inovadora, como fórmula de ordenação ótima das funções estatais. ${ }^{157}$

Assim, a divisão das funções estatais e a atribuição delas aos órgãos funcionalmente adequados implicam na desconcentração das tarefas do Estado, com a consequente salvaguarda contra o abuso do poder político (dimensão negativa), e na produção de decisões mais eficazes e justas (dimensão positiva). Se cada órgão do Estado é funcionalmente adequado ao desempenho de sua atividade, é sintomático que, em tese, suas decisões serão dotadas de maior eficácia e justeza.

Sob essa perspectiva, a Constituição de 1988 promoveu a reintegração do Poder Legislativo em sua função legislativa (suprimida durante o regime militar) ${ }^{158,159}$ e lhe atribuiu maiores poderes investigatórios sobre o processo político. Ao Poder Executivo, além do exercício da função de governo, foi atribuído amplo exercício da função legislativa. Por fim, ao Judiciário, a Constituição conferiu maiores garantias e instrumentos para a efetivação do controle da constitucionalidade dos atos emanados pelos demais Poderes, sendo esta específica questão fundamental para o exame da atuação do Supremo Tribunal Federal no pós-88.

Não obstante, apesar da cuidadosa sistematização das funções estatais para a manutenção do equilíbrio entre os Poderes, o que se verificou a partir da Constituição de 1988 não foi necessariamente a paridade entre os Poderes constituídos. Isso porque, no curso de seu desenvolvimento histórico, a variação quanto ao modelo organizatório do próprio Estado

\footnotetext{
${ }^{155}$ CANOTILHO, José Joaquim Gomes. Direito constitucional e teoria da constituição. 7. ed. Coimbra: Almedina, 2007, p. 500.

${ }^{156}$ Nesse sentido, referindo-se à Constituição Portuguesa de 1976, cf. CANOTILHO, José Joaquim Gomes. Direito constitucional e teoria da constituição. 7. ed. Coimbra: Almedina, 2007, p. 244.

${ }_{157}$ A esse respeito, também cf. PIÇARRA, Nuno. A separação dos Poderes como doutrina e princípio constitucional: contributo para o estudo das suas origens e evolução. Coimbra: Coimbra Editora, 1989, p. 262.

${ }^{158}$ Segundo Paulo Bonavides e Paes de Andrade, "Pode-se afirmar que o Legislativo começa a ser Poder com a promulgação da nova Carta constitucional." (História constitucional do Brasil. 8. ed. São Paulo: OAB Editora, 2006, p. 503).

${ }^{159}$ Embora não se pretenda, aqui, discutir a extensão e a adequação dessa restituição das funções ao Poder Legislativo, registre-se a crítica de José Afonso da Silva de que a Constituição de 1988 manteve muitos dos poderes legislativos com os quais o Poder Executivo foi dotado ao longo do período autoritário. Desta forma, não teriam sido revogadas muitas das prerrogativas que permitiram ao Executivo dirigir o processo legislativo durante o regime militar. (SILVA, José Afonso da. O constitucionalismo brasileiro: evolução institucional. São Paulo: Malheiros, 2011, p. 380.)
} 
provocou o fenômeno do protagonismo de determinados Poderes constituídos, a exemplo do que ocorreu na Europa a partir da Revolução Francesa, de $1789 .{ }^{160}$

Assim, na linha do quanto já foi exposto no primeiro capítulo, instaurado o Estado Social no Brasil, pela Constituição de 1934, foi sintomático o protagonismo do Poder Executivo. Por sua vez, com o início do Estado Democrático de Direito, instituído pela Constituição de 1988, embora se tenha notado uma tendência inicial à manutenção da proeminência do Poder Executivo, o Poder Judiciário assumiu o posto de destaque no cenário político deste início do século XXI.

Isso porque, nem o Poder Legislativo, nem o Poder Executivo lograram atender à principal promessa da Constituição de 1988, qual seja, a efetivação dos direitos fundamentais nela previstos. Assim, no exercício de sua função do controle de constitucionalidade dos atos e omissões daqueles Poderes, o Poder Judiciário vem se destacando como palco para a concretização dos direitos fundamentais, principalmente (mas não apenas) na omissão dos Poderes Legislativo e Executivo, bem como arena para tomada de outras decisões em questões de cunho político.

Com efeito, em vista do caráter analítico do texto constitucional e da expansão da jurisdição constitucional, o Supremo Tribunal Federal passou a apreciar um número crescente de questões políticas, fenômeno a que se tem chamado de "judicialização da política", e a suprir ativamente as omissões inconstitucionais dos demais Poderes no que se refere à concretização das normas constitucionais. Nessa medida, a principal decorrência da expansão do Poder Judiciário é a alegada usurpação da função legislativa (essencialmente, uma função política) pelo Supremo Federal Tribunal, contrapondo frontalmente os Poderes Legislativo e Judiciário.

Por estarem em evidência neste estudo, principalmente, os Poderes Legislativo e Judiciário, passa-se a analisar, inicialmente, a situação política do Poder Legislativo (e apenas tangencialmente a do Poder Executivo) após a promulgação da Constituição de 1988. Isso porque, como amplamente reconhecido na doutrina, o Legislativo sofreu evidente enfraquecimento no que se refere à sua função legislativa (perdendo espaço para o Executivo), o que pode ser apontado como um dos fatores da expansão do Poder Judiciário.

\footnotetext{
${ }^{160}$ Como demonstrado no Capítulo anterior, logo após a Revolução Francesa de 1789, de modo geral, verificouse o protagonismo do Poder Legislativo, como reação ao absolutismo monárquico. A partir do início do século $\mathrm{XX}$, foi a vez do Poder Executivo despontar no cenário político, em razão das dificuldades econômicas e sociais advindas da segunda fase da Revolução Industrial e do pós-guerra mundial. Por fím, já ao final do século XX e no início do século XXI, tem-se verificado a expansão do Poder Judiciário, como arena de defesa dos direitos e garantias constitucionais, haja vista a expansão da jurisdição constitucional nos Estados democráticos.
} 


\subsection{O Poder Legislativo na separação de Poderes da Constituição de 1988}

Relativamente à nova distribuição de funções entre os Poderes, promovida pela Constituição de 1988, deve-se atentar para que os debates no período imediatamente posterior à sua promulgação estiveram centrados principalmente nas relações entre os Poderes Legislativo e Executivo. Isso porque, embora o Poder Legislativo tenha, sem dúvida, recobrado sua autoridade, o Poder Executivo manteve muitos dos poderes legislativos com os quais fora dotado ao longo do período autoritário. ${ }^{161}$

Como consequência, mesmo após a promulgação da Constituição de 1988, o Poder Executivo continuou sobressaindo em relação ao Poder Legislativo, verificando-se o fenômeno denominado "hipertrofia" do Poder Executivo, ${ }^{162}$ ou seja, o amplo desempenho da função legislativa pelo Executivo, tendo por instrumento mais pungente as medidas provisórias (artigo 62 da Constituição de 1988), que se constituem em atos normativos exclusivos do Presidente da República, com características semelhantes às do decreto-lei espécie normativa extinta pelos constituintes e que foi responsável, em parte, pela grande concentração de funções no Poder Executivo durante o regime militar. ${ }^{163,164}$

\footnotetext{
${ }^{161}$ No entanto, seguindo a análise de Argelina Figueiredo e Fernando Limongi, o sistema político brasileiro hoje é bastante divergente do que vigorou em 1946 e durante o período autoritário, isto é, não há problemas tão profundos com relação à disciplina partidária e a votação no Congresso ocorre de maneira pacífica e cooperativa diante do poder Executivo. (FIGUEIREDO, Argelina e LIMONGI, Fernando. Executivo e Legislativo na Nova Ordem Constitucional. Rio de Janeiro: Editora FGV, 1999.). Ainda sobre a relação entre os Poderes Legislativo e Executivo, cf. PESSANHA, Charles. Relações entre os Poderes Executivo e Legislativo no Brasil: 1946-1994. 1997. Tese (Doutorado em Ciência Política) - Faculdade de Filosofia, Letras e Ciências Humanas, Universidade de São Paulo, São Paulo, 1997.

${ }^{162}$ Essa predominância do Poder Executivo foi matéria de diversos estudos, destacando-se a detida análise feita por Rubens Beçak (A hipertrofia do Executivo brasileiro: impacto da Constituição de 1988. 2005. 184 p. Tese (Doutorado) - Faculdade de Direito, Universidade de São Paulo, São Paulo, 2005.)

${ }_{163}$ Segundo Paulo Gustavo Gonet Branco, a medida provisória sucedeu o decreto-lei, que foi criação da Constituição de 1937. Não previsto na Constituição de 1946, o decreto-lei foi resgatado pela Constituição de 1967, com fixação de limites material e formal (urgência ou interesse público relevante). A não apreciação do decreto-lei pelo Poder Legislativo no prazo de 60 dias, tornava-o definitivo e, em sendo apreciado e rejeitado, as relações formadas durante a sua vigência permaneciam eficazes. Não obstante, os constituintes de 1988, sensíveis à relevância de manter a possibilidade de edição de medidas com força de lei pelo Presidente da República, para atender a necessidades urgentes e relevantes, criaram a medida provisória, ato normativo primário cujo procedimento, diferentemente do decreto-lei, garante participação mais atuante do Legislativo. Assim, se não for aprovada no prazo constitucional, pelo Legislativo, a medida provisória perde a sua eficácia desde a edição (artigo 62, $\S 2^{\circ}$ ). À semelhança do decreto-lei, a medida provisória deve atender ao pressuposto formal de relevância e urgência (artigo 62, caput). Quanto a seu limite material, a Constituição de 1988 não foi

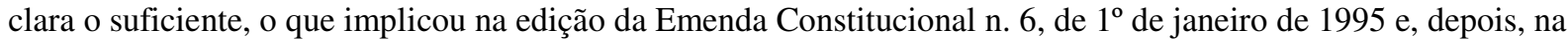
Emenda Constitucional n. 32, de 11 de setembro de 2011. Por meio desta, foram consolidados diversos traços
} 
Desde a promulgação da Constituição de $1988,{ }^{165}$ as medidas provisórias foram largamente utilizadas em detrimento das leis ordinárias, cuja edição, diferentemente das medidas provisórias, dependem de prévio processo legislativo, de cunho deliberativo e, por isso, vagaroso. Assim, o Poder Executivo passou a comandar o processo legislativo, minando o fortalecimento do Congresso Nacional, cuja importância no desempenho da função de produção legislativa ficou notoriamente prejudicada. Em suma, na medida em que o Poder Executivo assumiu o papel de principal legislador de direito e de fato, o Poder Legislativo foi conduzido a um estado de letargia, a um estágio pré-falimentar, como afirma Monica Herman Salem Caggiano. ${ }^{166}$

Manoel Gonçalves Ferreira Filho fala em efetiva "falência" dos Parlamentos quanto à função legislativa, explicando que essa condição se deve à própria crise da lei, tendo em vista a morosidade do processo legislativo e os interesses que influenciam a produção legislativa, emergindo daí a necessidade do desempenho dessa função pelo Poder Executivo, de forma mais célere:

É notório que os Parlamentos não dão conta das "necessidades" legislativas dos Estados contemporâneos; não conseguem, a tempo e a hora, gerar leis que os governam reclamam, que os grupos de pressão solicitam. As normas que tradicionalmente pautam o seu trabalho dão - é certo - ensejo a delongas, oportunidades a manobras e retardamentos. Com isso, os projetos se acumulam e atrasam. E esse atraso, na palavra do governo, no murmúrio da opinião pública, é a única e exclusiva razão por que os males de que sofre o povo não são aliviados.

Nem estão os Parlamentos, por sua própria organização, em condições de desempenhar, lentamente, mas a contento, a função legislativa. O modo de escolha de seus membros torna-os pouco frequentados pela ponderação e pela cultura, mas extremamente sensíveis à demagogia e à advocacia em causa própria. Os interesses não tem dificuldade em encontrar porta-vozes eloquentes, o bem comum nem sempre os acha.

\footnotetext{
jurisprudenciais e algumas postulações doutrinárias que conformaram o instrumento da medida provisória, acrescentando várias limitações materiais explícitas ao seu uso (artigo 62, § $1^{\circ}$ ). (MENDES, Gilmar Ferreira; BRANCO, Paulo Gustavo Gonet. Curso de direito constitucional. 8. ed. São Paulo: Saraiva, 2013, p. 875-878)

${ }_{164}$ Cite-se, ainda, como exemplo da hipertrofia do Poder Executivo, a relevante função legislativa exercida pelo Presidente da República, a quem a Constituição de 1988 conferiu iniciativa exclusiva de lei em matérias orçamentárias, vedando emendas parlamentares que impliquem a ampliação dos gastos previstos, e em matérias tributárias e relativas à organização administrativa, como destacam Argelina Figueiredo e Fernando Limongi. (FIGUEIREDO, Argelina e LIMONGI, Fernando. Executivo e Legislativo na Nova Ordem Constitucional. Rio de Janeiro: Ed. FGV, 1999, p. 25.)

${ }^{165}$ É possível verificar, a partir do site do Senado Federal brasileiro, todas as medidas provisórias editadas pelos Presidentes da República, sendo curioso notar que a primeira data de 03 de novembro de 1988, mês subsequente à promulgação da Constituição. $\quad$ Disponível http://www.planalto.gov.br/ccivil_03/mpv/Quadro/_Quadro\%20Geral.htm. Acesso em: 29 out. 2013.

166 CAGGIANO, Monica Herman Salem. A emergência do Poder Judiciário como contraponto ao bloco monomotor Legislativo/Executivo. In: MORAES, Alexandre (Coord.). Os 20 anos da constituição da Republica Federativa do Brasil. São Paulo: Atlas, 2009, p. 100.
} 
Ora, a incapacidade dos Parlamentos conduz à sua abdicação. Cá e lá, a delegação do Poder Legislativo, ostensiva ou disfarçada, torna-se a regra comum, apesar das proibições constitucionais. A imaginação dos constitucionalistas desvela-se em encontrar caminhos para que o Executivo possa legislar enquanto os magistrados olham para o outro lado afim de não verem as violações à Constituição. Mais ainda, desistindo de remar contra a corrente, Constituições recentes, como a francesa de 1958, a brasileira de 1967, dão ao Executivo verdadeiro poder legislativo autônomo. ${ }^{167}$

Dessa forma, resgatando a já referida lição de Rubens Beçak, é certo que essa transição funcional do Poder Legislativo brasileiro está inserida no contexto dos desenvolvimentos específicos de áreas de atuação de uns Poderes por sobre os outros, com o que os Poderes passam a assumir tarefas que, num primeiro momento, não lhes tinham sido destinadas. $^{168}$

Com efeito, no Brasil pós-88, a acomodação dos Poderes às específicas circunstâncias do Estado Democrático de Direito reduziu a importância do Poder Legislativo no desempenho da função legislativa, a qual lhe fora atribuída quase com exclusividade pela clássica Teoria da Separação de Poderes. No entanto, a perda no âmbito da legiferação foi compensada com um aumento significativo de seu poder fiscalizatório do processo político.

Ao discriminar as competências exclusivas do Congresso Nacional (artigo 48), a Câmara dos Deputados (artigo 51) e do Senado Federal (artigo 52), a Constituição previu, além de atribuições próprias de função legislativa, algumas de cunho "não-legislativo". O principal exemplo destas é função de fiscalização, tendo como expoente a possibilidade de investigação por meio das Comissões Parlamentares de Inquérito, ${ }^{169}$ mas também sendo exercida por debates internos relativos a políticas públicas, como destaca Rubens Beçak, que relaciona a deflagração dessa transição funcional do Legislativo ao resgate do impeachment nos anos 90 no Brasil, ${ }^{170}$ na Venezuela, no Peru, no Equador etc. ${ }^{171}$

\footnotetext{
${ }^{167}$ FERREIRA FILHO, Manoel Gonçalves. Do processo legislativo. 4. ed. São Paulo: Saraiva, 2001, p. 15.

${ }^{168}$ BEÇAK, Rubens. A hipertrofia do Executivo brasileiro: impacto da Constituição de 1988. 2005. 184 p. Tese (Doutorado) - Faculdade de Direito, Universidade de São Paulo, São Paulo, 2005, p. 36.

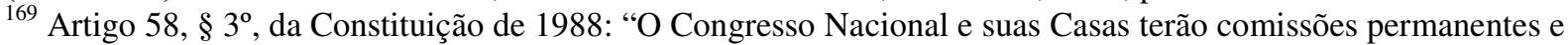
temporárias, constituídas na forma e com as atribuições previstas no respectivo regimento ou no ato de que resultar sua criação. (...) $\S 3^{\circ}$ As comissões parlamentares de inquérito, que terão poderes de investigação próprios das autoridades judiciais, além de outros previstos nos regimentos das respectivas Casas, serão criadas pela Câmara dos Deputados e pelo Senado Federal, em conjunto ou separadamente, mediante requerimento de um terço de seus membros, para a apuração de fato determinado e por prazo certo, sendo suas conclusões, se for o caso, encaminhadas ao Ministério Público, para que promova a responsabilidade civil ou criminal dos infratores." BRASIL. Constituição (1998). Constituição da República Federativa do Brasil. Brasília: Senado Federal, 1988.

170 Para excelente análise da origem do impeachment, sua evolução histórica, sua recepção pelo Direito brasileiro, e, inclusive, análise desse instituto à luz de sua utilização para deposição do ex-Presidente da
} 
No mesmo sentido, discorrendo sobre a posição do Poder Legislativo brasileiro no final do século XX, Caggiano observa que, superado o período de "pré-senilidade", o exercício da função fiscalizatória se revelou como uma nova forma de participação do Parlamento no cenário político:

É certo que as duas últimas décadas do século XX espelharam acentuada preocupação com o futuro dos Legislativos e sua aclimatação a um mundo de aceleradas transformações e sempre renovadas demandas. (...) Quer nos sistemas parlamentaristas, quer em ambientes presidenciais ou, ainda, nos quadros híbridos, os Parlamentos passaram a marcar presença no mundo da política, em razão da sua natureza representativa e de suas atividades de controle, do poder de vigilância política, espelhando-se essas na utilização dos instrumentos de investigação, a exemplo das CPIs e processos de impeachment. ${ }^{172}$

Cumpre mencionar a observação de Beçak, segundo a qual não há dúvidas de que os Legislativos, no geral, continuam a desempenhar importante papel legiferante, porém, que seu papel de agentes fiscalizadores e controladores se tornou muito mais evidente. ${ }^{173}$

Não obstante, apesar de o exercício dessa fiscalização ter resgatado a autoridade do Poder Legislativo no início dos anos 90, em artigo publicado em 2009, por ocasião da comemoração de 20 anos da promulgação da Constituição de 1988, Caggiano já alertava para uma realidade que contemporaneamente se descortina, a "retomada da fase de dormência parlamentar, sob o comando camuflado ou não do Executivo”. Isso se deve principalmente à banalização dos instrumentos de controle e à manipulação desses instrumentos em prol de

República, Fernando Collor de Melo, conferir BARROS, Sérgio Resende. Estudo sobre o "impeachment". Disponível em: http://www.srbarros.com.br/pt/estudo-sobre-o-impeachment.cont Acesso em: 23 Out. 2013. Também, PINTO, Paulo Brossard de Souza. O impeachment: aspectos da responsabilidade política do Presidente da República. 3. ed. São Paulo: Saraiva, 1992. No Brasil, especificamente sobre o impeachment do Presidente da República, Fernando Collor de Melo, ocorrido em 1992 (Caso Collor), cf. COMPARATO, Fabio Konder. O processo de impeachment e a importância constitucional do caso Collor. In: ROSENN, Keith S.; DOWNES, Richard (Org.). Corrupção e reforma política no Brasil: o impacto do impeachment de Collor. Rio de Janeiro: FGV Editora, 2000.

${ }^{171}$ BEÇAK, Rubens. O Tribunal Constitucional como regulador do processo político. Boletim Eletrônico da Escola Paulista de Direito. Boletim Eletrônico da Escola Paulista de Direito - EPD, v. 1, p. 2757-2772, 2007, p. 2765. Disponível em: http://www.conpedi.org.br/manaus/arquivos/anais/salvador/rubens_becak.pdf. Acesso em: 11 fev. 2013.

172 A emergência do Poder Judiciário como contraponto ao bloco monomotor Legislativo/Executivo. In: MORAES, Alexandre (Coord.). Os 20 anos da constituição da Republica Federativa do Brasil. São Paulo: Atlas, 2009, p. 101.

${ }^{173}$ BEÇAK, Rubens. O Tribunal Constitucional como regulador do processo político. Boletim Eletrônico da Escola Paulista de Direito. Boletim Eletrônico da Escola Paulista de Direito - EPD, v. 1, p. 2757-2772, 2007, p. 2766. Disponível em: http://www.conpedi.org.br/manaus/arquivos/anais/salvador/rubens_becak.pdf. Acesso em: 11 fev. 2013. 
interesses pessoais ou de determinados grupos, o que passou a realimentar o domínio do Executivo na cena política. ${ }^{174}$

A autora afirma que se está diante um verdadeiro bloco Executivo/Legislativo, bloco este que comanda o estabelecimento de políticas públicas e de decisões políticas. Sob essa perspectiva, retomando a lição de Montesquieu, a jurista coloca a "velha, séria e preocupante indagação: qual o poder que assegurará o equilíbrio neste cenário?”, sugerindo como resposta o Poder Judiciário. ${ }^{175}$

É incontestável que o Poder Legislativo vem atravessando grave crise institucional, não apenas em razão da perda de espaço no desempenho da função legislativa para o Poder Executivo, mas também pela inocuidade no desempenho da função fiscalizatória. Com frequência, as Comissões Parlamentares de Inquérito cedem ao corporativismo parlamentar ou a interesses particulares, por exemplo, dos financiadores de campanhas eleitorais, sem oferecer respostas aos cidadãos.

Outro fator determinante para a crise do Legislativo é a evidente crise de representatividade, que atinge os membros das Casas Legislativas Federais, Estaduais e Municipais, questão em pauta na chamada "Reforma Política", que visa a combater, dentre outros problemas, o enfraquecimento da representação política, por meio de modificações do sistema político-eleitoral brasileiro. ${ }^{176}$

No que se refere às dificuldades trazidas pelo sistema político brasileiro, Elival da Silva Ramos aponta a falta de consenso político em torno das medidas que devem ser adotadas pelo Poder Executivo, o que é incentivado pelo sistema presidencialista:

Tenho para mim que, ainda que não seja o único responsável pela defasagem entre a normatização necessária e a efetivamente alcançada, o sistema

\footnotetext{
174 A emergência do Poder Judiciário como contraponto ao bloco monomotor Legislativo/Executivo. In: MORAES, Alexandre (Coord.). Os 20 anos da constituição da Republica Federativa do Brasil. São Paulo: Atlas, 2009, p. 101-102.

175 A emergência do Poder Judiciário como contraponto ao bloco monomotor Legislativo/Executivo. In: MORAES, Alexandre (Coord.). Os 20 anos da constituição da Republica Federativa do Brasil. São Paulo: Atlas, 2009, p. 101-102.

${ }^{176}$ Há diversas propostas para a realização da "Reforma Política", advindas do Senado Federal, da Câmara dos Deputados e do meio acadêmico. Lewandowski destaca que as principais são as seguintes: “(i) a eliminação do sistema proporcional; (ii) o fim das coligações nas eleições proporcionais; (ii) a introdução da lista partidária fechada; (iv) a adoção do chamado "distritão"; do voto distrital puro, do distrital misto; ou, ainda, do proporcional por distrito; (v) a opção pelo financiamento exclusivamente público das campanhas; (vi) a abolição do voto obrigatório; (vii) a proibição de reeleição para o Executivo; (viii) a criação de uma nova cláusula de barreira; (ix) o recálculo da representação dos Estados e do Distrito Federal; (x) a apresentação de candidato municipal avulso; e (xi) a consulta popular para legitimar a reforma." (LEWANDOWSKI, Enrique Ricardo. Breves considerações sobre a reforma política em discussão no Congresso Nacional. In: CAGGIANO, Monica Herman Salem (Coord.); MESSA, Ana Flávia; ALMEIDA, Fernando Dias Menezes de. (Org.) Direito eleitoral em debate: estudos em homenagem a Cláudio Lembo. São Paulo: Saraiva, 2013, p. 419.)
} 
presidencialista tem contribuído para tanto. A estabilidade das maiorias parlamentares obtidas sem o emprenho da responsabilidade política do governo é bem menor do que a das constituídas por meio desse instrumento, dando ensejo, invariavelmente, a negociações em torno de cada votação de interesse do governo. O custo político dessas negociações, no interior do próprio bloco majoritário, leva o Poder Executivo a ser parcimonioso na formulação de suas propostas, excluindo ou atenuando as de menor nível de aceitação. ${ }^{177}$

Por sua vez, com relação ao sistema eleitoral, Elival da Silva Ramos reforça que a fragmentação da representação parlamentar entre inúmeras legendas partidárias, associada ao pluripartidarismo "atomístico" brasileiro, é condenada por quase todos os estudiosos de nossas instituições e consiste em um dos principais obstáculos à otimização dos trabalhos parlamentares. $^{178}$

Segundo Ferreira Filho, "o Parlamento somente cumpre seu papel de órgão decisório se nele se aglutina com razoável presteza, coerência e estabilidade, uma maioria", vale dizer, "uma maioria que vote as medidas reclamadas como necessárias pelo Executivo, no momento necessário, sem delongas ou retardamentos". O autor defende que o número excessivo de partidos políticos dificulta a definição dessa maioria e favorece "barganhas indignas", o que se agrava pelo fato de mitos partidos políticos não terem disciplina interna, dividindo-se em “alas que não perseguem senão seus interesses imediatos, não raro 'fisiológicos' ou eleitoreiros.". 179

Destaque-se, por oportuno, a recente onda de manifestações populares que tomaram as ruas do País desde junho de 2013. Ficou evidente a magnitude da insatisfação dos cidadãos com relação aos seus representantes, não apenas no Poder Legislativo, mas também no Poder Executivo. Embora fosse possível identificar reclamações sobre questões pontuais (como o aumento da tarifa do transporte público), as manifestações se inseriram em um contexto amplo de descontentamento generalizado com a classe política, em razão do abismo existente entre as aspirações populares e a atuação dos governantes e parlamentares, acusados não apenas de omissão quanto a diversas necessidades sociais e econômicas do povo, mas também de ações contrárias ao interesse deste (incluindo-se aqui os incontáveis escândalos de corrupção e desvios de verba pública).

\footnotetext{
${ }^{177}$ RAMOS, Elival da Silva. Ativismo judicial: parâmetros dogmáticos. São Paulo: Saraiva, 2010, p. 290.

${ }^{178}$ RAMOS, Elival da Silva. Ativismo judicial: parâmetros dogmáticos. São Paulo: Saraiva, 2010, p. 291.

${ }_{179}$ FERREIRA FILHO, Manoel Gonçalves. Aspectos do direito constitucional contemporâneo. São Paulo: Saraiva, 2003, p. 138.
} 
Conforme Celso Campilongo, o cenário político atual indica um esvaziamento do circuito Governo/Parlamento, o enfraquecimento da democracia representativa e a perda de representatividade dos partidos políticos. Isso faz com que surjam novos atores sociais, tais como as associações de moradores, movimentos sociais e organizações não governamentais, que se organizam para lutar por questões pontuais, específicas e de curtíssimos prazo. ${ }^{180}$

Esses novos atores, especialmente aqueles que representam "setores mais fragilizados da sociedade" não enxergam no circuito Governo/Legislativo o seu interlocutor político. Ao contrário, como sugeriu Caggiano em passagem referida acima, esse novos atores passaram a buscar no Poder Judiciário a "afirmação de seus direitos". ${ }^{181}$

No mesmo sentido, segundo Luiz Werneck Vianna, a atual valorização do Poder Judiciário pode ser explicada como uma "resposta à desqualificação da política e derruimento do homem democrático, nas novas condições acarretadas pela decadência do Welfare State", o que faria com que esse Poder passasse a ser visto como "salvaguarda confiável das expectativas por igualdade e a se comportar de modo substitutivo ao Estado, aos partidos, à família, à religião, que não mais seriam capazes de continuar cumprindo as suas funções de solidarização social. ${ }^{182}$

Com efeito, o Poder Judiciário, guardião dos direitos fundamentais, passa a ser visto como uma espécie de contrapeso ao Poder Legislativo e ao Poder Executivo, enquanto todos os três Poderes, na qualidade de Poderes constituídos, estão subordinados aos ditames constitucionais e, por isso, vinculados aos direitos fundamentais consagrados pela constituição. $^{183}$

É neste contexto que os estudos sobre o braço de guerra entre o Poder Legislativo e o Poder Executivo, nos primeiros anos de vida da Constituição de 1988, cederam espaço à análise da atual tensão entre o Poder Judiciário e os Poderes Executivo e Legislativo, o que sugere a possibilidade de construção de uma cidadania à paralela ao circuito

${ }^{180}$ CAMPILONGO, Celso. Os desafios do Judiciário: um enquadramento teórico. In: FARIA, José Eduardo (Org.). Os direitos humanos, direitos sociais e justiça. São Paulo: Malheiros, 2002, p. 32-34.

${ }^{181}$ CAMPILONGO, Celso. Os desafios do Judiciário: um enquadramento teórico. In: FARIA, José Eduardo (Org.). Os direitos humanos, direitos sociais e justiça. São Paulo: Malheiros, 2002, p. 32-34. Sobre a pressão dos movimentos sociais sobre o Poder Judiciário, ver LOPES, José Reinaldo de Lima. Crise da norma jurídica e reforma do Judiciário. In: FARIA, José Eduardo (Org.). Os direitos humanos, direitos sociais e justiça. São Paulo: Malheiros, 2002, p. 80-81.

182 VIANNA, Luiz Werneck; CARVALHO, Maria Alice Rezende de; MELO, Manuel Palacios Cunha; BURGOS, Marcelo Baumann. A judicialização da política e das relações sociais no Brasil. Rio de Janeiro: Revan, 1999, p. 24-25.

${ }^{183}$ PIÇARRA, Nuno. A separação dos poderes como doutrina e princípio constitucional: um contributo para o estudo das suas origens e evolução. Coimbra: Coimbra Editora, 1989, p. 196. 
Governo/Parlamento, transformando-se o Poder Judiciário em uma arena muito importante para a luta pela expansão da cidadania.

Sem prejuízo da elucidação dessa questão mais à frente (oportunidade em que examinaremos a chamada "judicialização da política"), é importante analisar os fatores que possibilitaram ao Poder Judiciário participar mais ativamente no cenário político brasileiro, com especial atenção, ao papel desempenhado pelo Supremo Tribunal Federal.

A identificação desses fatores possibilitará uma análise mais detida sobre a atuação do Supremo Tribunal Federal sob a égide da Constituição de 1988 e possíveis interferências da Corte no atual diálogo institucional entre o Poder Judiciário e Legislativo.

2.4. O protagonismo do Poder Judiciário: expansão da jurisdição constitucional

A expansão do Poder Judiciário após a promulgação da Constituição de 1988, com especial ênfase a partir dos primeiros anos do século XXI, se deu no contexto de enfraquecimento institucional dos Poderes Legislativo e Executivo, daí ser razoável afirmar que o Poder Judiciário emergiu como contraponto àqueles Poderes.

Sumarizando a atual composição de funções dos Poderes estatais no Brasil, José Renato Nalini destaca a posição do Judiciário e da crescente busca, nesta instância, pela superação das anomalias do Legislativo e do Executivo:

Numa era em que o Executivo é a maior fonte normativa - não apenas as Medidas Provisórias, mas a prolixa edição de regras pelas agências reguladoras, pelo CADE, pelo Banco Central e todas as demais exteriorizações do governo - o Parlamento se retrai. Tanto que a maior parcela de atuação do Legislativo não é editar normas, senão exercer atribuições próprias ao Judiciário, sob a forma de CPIs. Para compensar as anomalias, o Judiciário na verdade administra, sob a forma de liminares, antecipações de tutela e a presença do STF no comando de quase todas as políticas contemporâneas. O século XXI é o período em que a Justiça se propõe a enfrentar todos os desafios. Sem ativismo, porque ela continua servil ao princípio da inércia: só age quando provocada. Mas a provocação do Judiciário chega ao paroxismo, até mesmo perante a aparente perda de 
capacidade de diálogo que se instaurou numa sociedade que prefere o litígio à composição. ${ }^{184}$

Nessa linha de pensamento, Mauro Cappelletti, em Juízes legisladores?, aduz que, diante da crise do mundo contemporâneo, de que são sintomas o gigantismo do Poder Legislativo (“chamado a intervir ou a 'interferir' em esferas sempre maiores de assuntos e de atividade") e do Poder Executivo, os tribunais precisam optar por uma das seguintes alternativas: “a) permanecer fieis, com pertinácia, à concepção tradicional, tipicamente do século XIX, dos limites da função jurisdicional, ou b) elevar-se ao nível dos outros poderes, tornar-se enfim o terceiro gigante, capaz de controlar o legislador mastodonte e o leviatanesco administrador.". ${ }^{185}$

Seja no desempenho de suas funções típicas, seja no desempenho de funções atípicas que lhe foram atribuídas, os Poderes Legislativo e Executivo vêm falhando na tarefa de atender plenamente aos objetivos constitucionais da República Federativa do Brasil, principalmente, vêm falhando em conferir plena efetividade aos direitos fundamentais previstos na Constituição de 1988.

Isso porque, como referimos anteriormente, tanto a produção das leis infraconstitucionais, quanto a efetivação dos direitos por meio de políticas públicas, é frequentemente obstada pelos diversos interesses antagônicos inseridos no jogo político a que se submetem o Poder Legislativo e o Poder Executivo, e também pela escassez dos recursos públicos.

Independentemente dos motivos que levam os Poderes Legislativo e Executivo a não conferirem efetividade às normas constitucionais, a Constituição de 1988 consolidou o modelo do controle de constitucionalidade brasileiro, reforçando em especial o controle abstrato realizado pelo Supremo Tribunal Federal - por meio da criação de instrumentos processuais capazes de otimizar esse controle e do aumento do rol de legitimados a utilizar esses instrumentos -, que passou a ser realizado não apenas quanto aos atos inconstitucionais dos Poderes Legislativo e Executivo, mas sobretudo quanto às omissões inconstitucionais.

\footnotetext{
${ }^{184}$ NALINI, José Renato. O Poder Judiciário na Constituição de 1988. In: MARTINS, Ives Gandra da Silva; MENDES, Gilmar Ferreira; NASCIMENTO, Carlos Valder do. (Coord.) Tratado de Direito Constitucional. v. 1. São Paulo: Saraiva, 2010, p. 963-964.

${ }^{185}$ CAPPELLETTI, Mauro. Juízes legisladores? Tradução de Carlos Alberto Álvaro de Oliveira. Porto Alegre: Sérgio Antonio Fabris, 1993, p. 46-47.
} 
O desenvolvimento do controle de constitucionalidade, portanto, viabilizou a expansão da jurisdição constitucional. Por sua vez, tendo em vista que a Constituição de 1988 é analítica, o Supremo Tribunal Federal, ao exercer esse controle, passou a julgar matérias de cunho eminentemente político, antes reservadas às decisões dos Poderes representativos.

Nesse sentido, Gilmar Mendes afirma que a Constituição de 1988 ampliou significativamente a competência originária do Supremo Tribunal Federal, especialmente no que concerne ao controle de constitucionalidade de leis e atos normativos e ao controle da omissão inconstitucional. ${ }^{186}$

Do mesmo modo, em lição sobre o crescente destaque do Poder Judiciário, o Ministro Ricardo Lewandowski explica a inédita interferência do Supremo Tribunal Federal nos processos político, social e econômico, não só autorizada, mas incentivada pela Constituição de 1988:

E a nossa Constituição realmente escancarou as Portas do Poder Judiciário. Não se trata de 11 ministros do Supremo Tribunal Federal que, de repente, tenham resolvido intervir mais ativamente no processo político e social, ou mesmo econômico, é porque isso se insere dentro de um quadro relativamente mais amplo.

A Constituição de 1988 escancarou as portas do Poder Judiciário, primeiro porque deu efetividade, repetiu no seu texto o princípio da universalidade da jurisdição (art. 5', XXXV, "nenhuma lesão, ou ameaça de lesão ao direito, pode ser subtraída da apreciação do Poder Judiciário"), procurando dar-lhe eficiência.

Além disso, a Constituição criou uma série de instrumentos novos e que talvez não encontrem paralelo em outros ordenamentos jurídicos (...). ${ }^{187}$

Lewandowski destaca que o protagonismo do Poder Judiciário deve-se também à adoção de uma nova interpretação constitucional, afastada dos moldes clássicos de aplicação mecânica das leis ao caso concreto, que reconhece a eficácia dos princípios constitucionais, ampliando ainda mais as possibilidades de atuação do Supremo Tribunal Federal:

O Judiciário supera a hermenêutica tradicional, que desvenda, que descobre o direito, a partir das regras jurídicas exclusivamente; ele passou a desvendar o direito a partir dos princípios, superando a visão ortodoxa que se tinha de que os princípios seriam meras normas programáticas, ou seja, um mero programa de ação dirigido ao Executivo, ao Legislativo e ao Judiciário: são metas, se der para atingir, se não der, paciência; agora, realmente entende-se que os princípios são normas constitucionais dotadas de eficácia e que

\footnotetext{
${ }^{186}$ MENDES, Gilmar Ferreira; BRANCO, Paulo Gustavo Gonet. Curso de direito constitucional. 8. ed. São Paulo: Saraiva, 2013, p. 901.

${ }^{187}$ LEWANDOWSKI, Enrique Ricardo. O protagonismo do Poder Judiciário na era dos direitos. Revista de Direito Administrativo, n. 251, p. 77-85, mai/ago. 2009, p. 85-86.
} 
devem ser realmente aplicadas pelos operadores do direito em suas várias especialidades. ${ }^{188}$

Em conclusão, Lewandowski afirma que a Constituição brasileira é analítica, ou seja, "quase tudo está na Constituição, e, portanto, quase tudo pode ser levado à discussão no Supremo Tribunal Federal". ${ }^{189}$ Como bem ressaltado, é certo que a expansão do controle de constitucionalidade e da nova interpretação constitucional (por meio da qual se reconhece a eficácia imediata dos direitos fundamentais) resultou em um aumento significativo da variedade de questões, muitas delas com caráter político, levadas à apreciação do Poder Judiciário, que ganhou posição de evidente destaque, principalmente com relação ao Poder Legislativo, como será exposto adiante.

2.4.1. Consolidação do controle de constitucionalidade

A atividade expandida do Poder Judiciário, que hoje é apontada, teve como ponto de partida o nascimento da justiça constitucional na jurisprudência e na doutrina norte-americana e foi estimulada pelo alargamento do campo do processo constitucional em panorama europeu.

Em 1803, no julgamento do célebre caso Marbury v. Madison, a Suprema Corte dos Estados Unidos reconheceu, pela primeira vez, a necessidade de perfeito alinhamento do quadro infraconstitucional à Constituição, tendo em vista a supremacia desta, criando o controle de constitucionalidade das leis (judicial review) e deflagrando seu posterior desenvolvimento no restante dos Estados em que vigem constituições rígidas.

De fato, foi apenas no século XX que, sob a influência da doutrina da judicial review norte-americana, desenvolveu-se o controle de constitucionalidade na Europa, sob a liderança de Hans Kelsen. Diferentemente da fórmula norte-americana, Kelsen formulou a justiça

${ }^{188}$ LEWANDOWSKI, Enrique Ricardo. O protagonismo do Poder Judiciário na era dos direitos. Revista de Direito Administrativo, n. 251, p. 77-85, mai/ago. 2009, p. 81-82.

${ }^{189}$ LEWANDOWSKI, Enrique Ricardo. O protagonismo do Poder Judiciário na era dos direitos. Revista de Direito Administrativo, n. 251, p. 77-85, mai/ago. 2009, p. 81-82. 
constitucional com base na criação de tribunais constitucionais, órgãos com poderes normativos e que exercem com exclusividade a preservação da supremacia constitucional e a tutela dos direitos garantidos pela Constituição. ${ }^{190}$

A existência do controle de constitucionalidade tem como pressuposto fundamental o princípio da rigidez constitucional, que implica em maior dificuldade para a modificação da constituição do que para a alteração das demais normas jurídicas, e o consequente princípio da supremacia constitucional, segundo o qual a constituição constitui o fundamento de validade das normas infraconstitucionais, de modo que estas sempre devem ser compatíveis com aquelas (compatibilidade vertical). ${ }^{191}$

Nessa medida, o controle de constitucionalidade pode ser entendido como um "mecanismo jurídico de censura dos atos que desrespeitam a constituição", nas palavras de Gilmar Ferreira Mendes, que explica, ainda, que não se pode tolerar a produção de norma contrária à Constituição porque isso significaria usurpar a competência do Poder constituinte. "Este, sim, passa a ser a voz primeira do povo, condicionante das ações dos poderes por ele constituídos. A Constituição assume o seu valor mais alto por sua origem - por ser o fruto do poder constituinte originário.". 192

No que se refere ao caso brasileiro, verifica-se que a Constituição de 1988, inequivocamente dotada de rigidez, haja vista o número reduzido de legitimados para propor emendas ao texto constitucional e o elevado quórum para aprovação dessas emendas (artigo 60 da Constituição Federal), prevê um sistema misto de controle de constitucionalidade.

Isto é, o controle judicial de constitucionalidade pode ser realizado de forma difusa, pelo que compete a todo juiz exercer o controle de constitucionalidade, incidentalmente, sobre as leis aplicáveis ao caso concreto, ou de forma concentrada, pelo que a corte constitucional

\footnotetext{
${ }^{190}$ Cf. KELSEN, Hans. Jurisdição constitucional. 3. ed. São Paulo: Martins Fontes, 2013.

${ }^{191}$ Kelsen concebe o ordenamento jurídico como um sistema hierárquico de normas em que a validade de uma norma pode ser verificada em função da sua conformidade com uma norma hierarquicamente superior. $\mathrm{O}$ sistema positivista não comporta o reconhecimento de uma lei moral objetiva ou de uma lei natural como critério de validade da norma positiva, nem indaga da justiça ou injustiça das leis. Se a norma está de acordo com a norma superior hierárquica numa cadeia sucessória ou piramidal, ela é válida. Qualquer referencial externo ao sistema jurídico é rejeitado. A última norma desta estrutura hierárquica, no entanto, não pode ter sua validade verificada em função de uma norma superior. Kelsen chama esta norma superior máxima de "norma fundamental", a qual constitui o fundamento de validade de todo o sistema jurídico. (KELSEN, Hans. A teoria pura do direito. 8. ed. São Paulo: Martins Fontes, 2009, p. 95.)

${ }^{192}$ MENDES, Gilmar Ferreira; BRANCO, Paulo Gustavo Gonet. Curso de direito constitucional. 8. ed. São Paulo: Saraiva, 2013, p. 48.
} 
examina a validade da lei, em abstrato, diante da Constituição, por provocação específica para esse fim. ${ }^{193}$

A estruturação desse modelo de controle de constitucionalidade decorreu de gradual desenvolvimento ao longo da trajetória constitucional brasileira, sendo que a maior conquista da Constituição de 1988, nesse âmbito, foi a consolidação do controle concentrado das normas, exercido com exclusividade pelo Supremo Tribunal Federal.

Inicialmente, por influência da Constituição francesa de 1791, a Constituição Imperial do Brasil (1824) consagrou o dogma da soberania do Parlamento, de tal modo que outorgou ao Poder Legislativo a atribuição de "fazer lei, interpretá-las, suspendê-las e revogá-las", bem como "velar na guarda da Constituição" (artigo 15, § $8^{\circ}$ e $9^{\circ}$ ), sendo vedado ao Poder Judiciário manifestar-se sobre o conteúdo delas. ${ }^{194}$ Não havia, portanto, espaço para o incipiente modelo de controle judicial de constitucionalidade. ${ }^{195}$

Sob a onda de influência do judicial review estadunidense, a Constituição de 1891 incorporou e consolidou o controle de constitucionalidade judicial por via difusa de leis estaduais ou federais nos artigos 59, $\S 1^{\circ}$, $a$, e $60, a .{ }^{196}$ Em trabalho elaborado em 1893, Rui Barbosa comentava a amplitude com que esse instituto foi inserido na Constituição brasileira, de forma mais contundente até do que na Constituição americana. ${ }^{197}$

\footnotetext{
193 A respeito do sistema de controle de constitucionalidade brasileiro, diga-se ainda que, ao lado controle judicial, existe também previsão de controle político, realizado pelo Poder Legislativo (controle da constitucionalidade dos projetos de lei, por meio das comissões de constituição e justiça, e de controle sobre medidas provisórias) e pelo Poder Executivo (veto a projeto de lei inconstitucional ou contrário ao interesse público). Em regra, o controle político acontece preventivamente, tendo por objeto o projeto de lei, ao passo que o controle judicial acontece de forma repressiva, pressupondo a vigência da lei e visando à declaração de sua nulidade.

${ }^{194}$ Saliente-se a lição de José Antonio Pimenta Bueno de que o conteúdo da lei somente poderia ser definido pelo órgão legiferante: "Só o poder que faz a lei é o único competente para declarar por via de autoridade ou por disposição geral obrigatória o pensamento, o preceito dela. Só ele e exclusivamente ele é quem tem o direito de interpretar o seu próprio ato, suas próprias vistas, sua vontade e seus fins. Nenhum outro poder tem o direito de interpretar por igual modo, já porque nenhuma lei lhe deu essa faculdade, já porque seria absurda a que lhe desse." (PIMENTA BUENO, José Antonio. Direito público brasileiro e análise da Constituição do Império. Brasília: Senado Federal, 1978, p. 69.)

${ }^{195}$ Nesse sentido, cf. BITTENCOURT, Carlos Alberto Lúcio. O controle jurisdicional de constitucionalidade das leis. 2. ed. Rio de Janeiro: Forense, 1968, p. 27-28; BANDEIRA DE MELLO, Oswaldo Aranha. Teoria das constituições rígidas. 2. ed. São Paulo: Bushatsky, 1980, p. 155.

196 Confira-se a redação desses dispositivos: “Art. 59. Ao Supremo Tribunal Federal compete: (...) $\S 1^{\circ}$ - Das sentenças das Justiças dos Estados, em última instância, haverá recurso para o Supremo Tribunal Federal: a) quando se questionar sobre a validade, ou a aplicação de tratados e leis federais, e a decisão do Tribunal do Estado for contra ela; b) quando se contestar a validade de leis ou de atos dos Governos dos Estados em face da Constituição, ou das leis federais, e a decisão do Tribunal do Estado considerar válidos esses atos, ou essas leis impugnadas." e "Art. 60. Compete aos Juízes ou Tribunais Federais, processar e julgar: a) as causas em que alguma das partes fundar a ação, ou a defesa, em disposição da Constituição federal." BRASIL. Constituição (1988). Constituição da República Federativa do Brasil. Brasília: Senado Federal, 1988.

197 "O único lance da Constituição americana, onde se estriba ilativamente o juízo, que lhe atribui essa intenção, é o art. III, seç. $2^{\text {a }}$, cujo teor reza assim: 'O poder judiciário estender-se-á a todas as causas, de direito e equidade,
} 
Gilmar Ferreira Mendes observa, porém, que era inequívoca a consciência de que o controle de constitucionalidade não se haveria de fazer em abstrato. ${ }^{198}$ Essa possibilidade somente foi esboçada, pela primeira vez, na Constituição de 1934.

Segundo Paulo Bonavides, a inovação mais importante trazida por essa Constituição, com respeito ao desenvolvimento do controle por via de ação, foi a provocação do Procurador-Geral da República para que a Corte Suprema declarasse inconstitucional lei federal que houvesse decretado a intervenção da União no Estado-membro em caso de inobservância de certos princípios constitucionais (artigo 12, § $2^{\circ}$ ). ${ }^{199}$

Isso porque o controle pelo Supremo Tribunal se faria, não mais apenas no transcurso de uma demanda, mas por efeito de uma provocação cujo objeto em si era a declaração de constitucionalidade da lei interventiva. ${ }^{200}$ Não obstante, Pontes de Miranda advertia que não se tratava de formulação de um juízo político, exclusivo do Poder Legislativo, mas de exame puramente jurídico. ${ }^{201}$

A Carta de 1937, por sua vez, representou um inequívoco retrocesso ao desenvolvimento do sistema do controle de constitucionalidade. Embora o modelo difuso de controle não tenha sofrido alteração, o artigo 96, parágrafo único, consagrou o princípio

que nasceram desta Constituição, ou das leis dos Estados Unidos'. Não se diz aí que os tribunais sentenciarão sobre a validade, ou invalidade, das leis. Apenas se estatui que conhecerão das causas regidas pela Constituição, como conformes ou contrárias a ela. Muito mais contundente é a Constituição brasileira. Nela não só se prescreve que 'Compete aos Juízes ou Tribunais Federais, processar e julgar as causas em que alguma das partes fundar a ação, ou a defesa, em disposição da Constituição federal.' (art. 60, a) como, ainda, que 'Das sentenças das Justiças dos Estados, em última instância, haverá recurso para o Supremo Tribunal Federal, quando se questionar sobre a validade, ou a aplicação de tratados e leis federais, e a decisão do Tribunal do Estado for contrária' (art. 59, $\S 1^{\circ}, a$ ). A redação é claríssima." (BARBOSA, Rui. Os atos inconstitucionais do Congresso e do Executivo. In: ___ _ Trabalhos jurídicos. Rio de Janeiro: Casa de Rui Barbosa, 1962, p. 54-55.)

198 MENDES, Gilmar Ferreira; BRANCO, Paulo Gustavo Gonet. Curso de direito constitucional. 8. ed. São Paulo: Saraiva, 2013, p. 1038. Com efeito, Rui Barbosa afirmava que "Os tribunais não intervêm na elaboração da lei, nem na sua aplicação geral. Não são órgãos consultivos nem para o legislador, nem para a administração (...)", ressaltando que a judicial review "é um poder de hermenêutica, e não um poder de legislação." (BARBOSA, Rui. Os atos inconstitucionais do Congresso e do Executivo. In: Trabalhos jurídicos. Rio de Janeiro: Casa de Rui Barbosa, 1962, p. 83.)

199 Além da referida inovação, Paulo Bonavides destaca outras três que configuram a relevante contribuição da Constituição de 1934 ao aperfeiçoamento do controle de constitucionalidade brasileiro. São elas: (i) "o instituto da maioria absoluta de votos da totalidade dos juízes, como requisito indispensável à declaração, pelos tribunais, da inconstitucionalidade de lei ou de ato do poder público"; (ii) "a competência deferida ao Senado Federal para suspender a execução total ou parcial de qualquer lei ou ato, deliberação ou regulamento, cuja inconstitucionalidade haja sido declarada pelo Poder Judiciário"; e (iii) "a instituição do mandado de segurança "para a defesa de direito certo e incontestável, ameaçado ou violado por ato manifestamente inconstitucional ou ilegal de qualquer autoridade.”. (BONAVIDES, Paulo. Curso de direito constitucional. 25. ed. São Paulo: Malheiros, 2009, p. 328.)

200 Diga-se que essa previsão de controle foi denominada por Oswaldo Aranha Bandeira de Mello como "declaração de inconstitucionalidade para evitar intervenção federal". (BANDEIRA DE MELLO, Oswaldo Aranha. Teoria das constituições rígidas. 2. ed. São Paulo: Bushatsky, 1980, p. 170.)

201 PONTES DE MIRANDA, Francisco Cavalcanti. Comentários à Constituição da República dos Estados Unidos do Brasil. v. 1. Rio de Janeiro: Guanabara, 1938, p. 364. 
segundo o qual, no caso de ser declarada a inconstitucionalidade de uma lei que, a juízo do Presidente da República, seja necessária ao bem-estar do povo, à promoção ou defesa de interesse nacional de alta monta, poderia o Chefe do Executivo submetê-la novamente ao Parlamento. ${ }^{202}$ Se confirmada a validade da lei por dois terços de votos em cada uma das Câmaras, tornava-se insubsistente a decisão do Tribunal. ${ }^{203}$

Findo o Estado Novo, período em que vigeu o que Ivo Dantas denominou um “constitucionalismo aparente", ${ }^{204}$ a Carta de 1937 foi substituída pela Constituição de 1946.

No que se refere ao controle de constitucionalidade, a Constituição de 1946 voltou a apresentar o tratamento que lhe fora dado pelas Constituições de 1891 e, sobretudo, de 1934. No entanto, foi apenas com a Emenda Constitucional n. 16, de 26 de novembro de 1965, editada em pleno regime militar, que se instituiu no ordenamento jurídico brasileiro o controle abstrato de normas estaduais e federais, o qual não mais haveria de se limitar à hipótese de funcionar como requisito prévio para a decretação da intervenção federal, conforme nova redação conferida ao artigo 101, I, $k$, que conferiu ao Supremo Tribunal Federal a competência para processar e julgar, originariamente, a representação contra inconstitucionalidade de lei ou ato de natureza normativa, federal ou estadual, encaminhada pelo Procurador-Geral da República.

Após, durante a vigência da Constituição de 1967, manteve-se incólume o controle difuso de constitucionalidade, sendo que a ação direta de constitucionalidade, prevista no artigo 114, I, l, subsistiu tal como prevista na Constituição de 1946, com a Emenda Constitucional n. 16, de 26 de novembro de 1965.

No entanto, é salutar a ressalva aventada por Ivo Dantas, destacando a inocuidade da previsão de tal instituto:

\footnotetext{
${ }^{202}$ Sobre a aplicação desse princípio, Carlos Alberto Lúcio Bittencourt narra, em interessante passagem, que, em 1939, quando o Presidente Getúlio Vargas editou o Decreto-Lei n. 1.564, de 5 de setembro de 1939, confirmando textos de lei declarados inconstitucionais pelo Supremo Tribunal Federal, os meios judiciários reagiram com intensidade. Embora Lúcio Bittencourt expresse que, em seu entendimento, o Presidente não fizera mais do que "cumprir, como era de seu dever, o prescrito no art. 96 da Carta Constitucional", pondera que a celeuma causada pela desautorização dos atos judiciais "está a demonstrar como se encontra arraigado em nosso pensamento jurídico o princípio que confere à declaração judicial caráter incontrastável, em relação ao caso concreto.". (BITTENCOURT, Carlos Alberto Lúcio. O controle jurisdicional da constitucionalidade das leis. 2. Ed. Rio de Janeiro: Forense, 1968, p. 139-140.)

${ }^{203}$ Também no sentido de reduzir a autonomia do Poder Judiciário, o artigo 94 da Carta de 1937 vedou ao Judiciário conhecer de questões exclusivamente políticas.

${ }^{204}$ Isso porque o artigo 187 daquela Constituição nunca chegou a ser cumprido: "Esta Constituição entrará em vigor na sua data e será submetida ao plebiscito nacional na forma regulada em Decreto pelo Presidente da República." Cf. DANTAS, Ivo. $O$ valor da constituição: do controle de constitucionalidade como garantia de supralegalidade constitucional. 2. ed. Rio de Janeiro: Renovar, 2001, p. 94.
} 
(...) apesar do permissivo citado, nenhum ato emanado sob a proteção da legislação mencionada nos incisos I a IV do art. 173 (ADGT) poderia ser objeto de representação, o que significava que o instituto não funcionava em toda a sua plenitude. Aliás, para que se sinta o clima em que à época funcionava o Poder Judiciário no Brasil, basta que sejam citadas as aposentadorias dos Ministros Antonio Carlos Lafayette de Andrade e Antonio Gonçalves, os quais tomaram tal atitude em razão de Habeas Corpus que concederam a líderes estudantis ligados à UNE (.... $)^{205}$

Ainda durante o período da ditadura militar, sem olvidar da ressalva acima referida, o controle de constitucionalidade sofreu outras modificações. A Emenda Constitucional n. 1, de 17 de outubro de 1969, previu, expressamente, o controle de constitucionalidade de lei municipal, em face da Constituição Estadual, para fins de intervenção no município (artigo 15, $\S 3^{\circ}, d$ ), a Emenda Constitucional n. 7, de 13 de abril de 1977, introduziu, ao lado da representação de inconstitucionalidade, a representação para fins de interpretação da lei ou ato normativo federal ou estadual, outorgando ao Procurador-Geral da República a legitimidade para provocar o pronunciamento do Supremo Tribunal Federal (artigo 119, I, e) e, por fim, a Emenda Constitucional n. 7 reconheceu expressamente a competência do Supremo Tribunal Federal para deferir pedido de "medida cautelar nas representações oferecidas pelo Procurador-Geral da República” (artigo 119, I, p).

Não obstante, a partir da promulgação da Constituição de 1988, e com a edição da Emenda Constitucional n. 3, de 17 de março de 1993 e da Emenda Constitucional n. 45, de 30 de dezembro de 2004 (conhecida como "Emenda da Reforma do Judiciário"), o controle de constitucionalidade sofreu inúmeras modificações, possibilitando grande ampliação da jurisdição constitucional no Brasil.

Dentre as novidades relativas ao sistema de controle de constitucionalidade, verificouse a ampliação do rol de legitimados para a propositura da ação direta de inconstitucionalidade, o que até então somente podia ser feito pelo Procurador-Geral da República (artigo 103). Nesse sentido, Ivo Dantas reforça o entendimento de que essa inovação beneficiou o controle concentrado das normas:

Tal fato fortalece a impressão de que, com a introdução desse sistema de controle abstrato de normas, com ampla legitimação e, particularmente, a outorga do direito de propositura a diferentes órgãos da sociedade, pretendeu o constituinte reforçar o controle abstrato de normas no ordenamento jurídico brasileiro como peculiar instrumento de correção do sistema geral incidente.

\footnotetext{
${ }^{205}$ DANTAS, Ivo. O valor da constituição: do controle de constitucionalidade como garantia de supralegalidade constitucional. 2. ed. Rio de Janeiro: Renovar, 2001, p. 103.
} 
Não é menos certo, por outro lado, que a ampla legitimação conferida ao controle abstrato, com a inevitável possibilidade de se submeter qualquer questão constitucional ao Supremo Tribunal Federal, operou uma mudança substancial - ainda que não desejada - no modelo de controle de constitucionalidade até então vigente no Brasil. ${ }^{206}$

Com efeito, se, até 1988, vigia um modelo misto de constitucionalidade, com forte acento no amplo e dominante sistema difuso, a Constituição de 1988 alterou, de maneira radical, essa situação, conferindo ênfase ao modelo concentrado de controle exercido pelo Supremo Tribunal Federal.

Diferentemente das anteriores, como reforço ao controle de suas normas, a Constituição de 1988 estabeleceu a possibilidade de controle de constitucionalidade das omissões inconstitucionais (decorrentes da inércia total ou parcial dos Poderes Legislativo e Executivo com relação à concretização de seus deveres constitucionais), seja de forma concentrada, por meio da ação declaratória de inconstitucionalidade por omissão (artigo 103, $\S 2^{\circ}$ ), seja de forma difusa, por meio do mandado de injunção (artigo $5^{\circ}$, LXXI).

Ainda, pela primeira vez, a Constituição previu a arguição de descumprimento de preceito fundamental, originariamente introduzida no parágrafo único do artigo 102. Posteriormente, a Emenda Constitucional n. 3/1993 realocou a previsão da arguição de descumprimento de preceito fundamental para o $\S 1^{\mathrm{o}}$ do artigo $102 \mathrm{e}$, ainda, criou mais um mecanismo de controle concentrado, a ação declaratória de constitucionalidade, inserida no artigo 102, I, $a$, juntamente com a ação declaratória de inconstitucionalidade.

Por fim, a Emenda Constitucional n. 45/2004 ampliou a legitimação para ajuizamento da ação declaratória de constitucionalidade, igualando aos legitimados para propositura da ação direta de inconstitucionalidade, e estendeu o efeito vinculante das decisões proferidas pelo Supremo Tribunal Federal na ação declaratória de constitucionalidade também para a decisão da ação direta de inconstitucionalidade (confirmando o que já dizia o artigo 28 da Lei n. 9.868/99 e a jurisprudência do STF).

No que refere ao controle concentrado, portanto, a análise da constitucionalidade ou inconstitucionalidade de uma lei pode chegar após provocação dos legitimados expressos no artigo 103 da Constituição de 1988, que o farão por meio de ações diretas, a saber, a ação direta de inconstitucionalidade, a ação declaratória de constitucionalidade, a arguição de

\footnotetext{
${ }^{206}$ MENDES, Gilmar Ferreira; MARTINS, Ives Gandra da Silva. Controle concentrado de constitucionalidade: comentários à Lei n. 9.868, de 10-11-1999. 3. ed. Saraiva: São Paulo, 2009, p. 86.
} 
descumprimento de preceito fundamental, a ação de inconstitucionalidade por omissão e a ação direta de inconstitucionalidade interventiva.

Dentre esses mecanismos, os principais são a ação direta de inconstitucionalidade e a ação declaratória de constitucionalidade. Para ambas, as decisões do STF tem efeito erga omnes e são vinculantes com relação ao Poder Executivo e aos demais órgãos do Poder Judiciário. Todavia, não impede que o Legislativo reproduza total ou parcialmente a mesma norma em diploma posterior, o que implica necessidade de o controle concentrado ser suscitado novamente caso a norma velha seja reproduzida com os mesmos vícios.

Por via incidental, a discussão a respeito da inconstitucionalidade ou constitucionalidade de leis aplicadas a caso concreto atinge o Supremo Tribunal Federal, principalmente, por meio do recurso extraordinário, pressupondo a análise dos incidentes de inconstitucionalidade pelos juízes anteriores e a repercussão geral do tema.

Além disso, a Constituição de 1988 trouxe outro mecanismo importantíssimo que viabiliza o controle de constitucionalidade pela via difusa, o mandado de injunção, previsto no artigo $5^{\circ}$, LXXI. Ao lado da ação de inconstitucionalidade por omissão, trata-se de mecanismo de controle das omissões inconstitucionais consubstanciadas na ausência de norma regulamentadora destinada a viabilizar "o exercício dos direitos e liberdades constitucionais e das prerrogativas inerentes à nacionalidade, à soberania e à cidadania.”.

No entanto, é importante ressaltar que a expansão da jurisdição constitucional no Brasil não se deve apenas ao incremento dos mecanismos de controle de constitucionalidade de ações ou omissões inconstitucionais. Ela conta ainda com outros instrumentos que visam a conferir maior autoridade às decisões proferidas por aquela Corte, tal como a súmula vinculante, inserida no artigo 103-A da Constituição de 1988 pela Emenda Constitucional n. 45/2004, e a reclamação constitucional, prevista no artigo 102, I, $l$.

A Constituição dispõe que, por meio de decisão de dois terços de seus membros, o Supremo Tribunal Federal pode, de ofício ou por provocação, após reiteradas decisões sobre determinada matéria constitucional, aprovar súmula que, a partir de sua publicação na imprensa oficial, tem efeito vinculante em relação aos demais órgãos do Poder Judiciário e à administração pública direta e indireta nas esferas municipal, estadual e federal.

A súmula vinculante, exemplo da expansão da jurisdição constitucional, tem raízes na stare decisis, advinda do sistema da Common Law (adotado nos Estados Unidos e Inglaterra, por exemplo), revelando forte tendência à adoção da construção jurisprudencial do Direito no 
Brasil, tradicionalmente vinculado ao sistema da Civil Law, em que o Direito se baseia quase totalmente em leis escritas. ${ }^{207}$

Embora tenha sido criada com o intuito de promover a celeridade processual e a uniformização da jurisprudência, a súmula vinculante recebeu numerosas críticas por conta de seu caráter vinculativo. Segundo Manoel Gonçalves Ferreira Filho, por exemplo, esse instrumento provocaria um enrijecimento exacerbado da interpretação em matéria constitucional, na medida em que cristaliza "a posição jurisprudencial, dificultando a sua adaptação a novos tempos, ou sua mudança em decorrência de novos argumentos." ${ }^{208}$ Por sua vez, Elival da Silva Ramos ressalta outro "efeito colateral perverso" da súmula vinculante, a saber, o fato de tal atribuição do Supremo Tribunal Federal poder vir a impulsionar o ativismo judicial, tendo em vista uma aproximação excessiva da atividade legiferante, a qual, apesar de compatível com o modelo de separação dos Poderes, já que contemplada pela Constituição, poderá, progressivamente, prejudicar suas bases. ${ }^{209}$

Finalmente, não se pode deixar de mencionar que a jurisdição constitucional também foi fortalecida em razão da criação da reclamação constitucional, instrumento processual previsto no artigo 103-A, $\S 3^{\circ}$, e artigo 102, I, $l$, da Constituição de 1988, que objetiva preservar a autoridade das decisões proferidas pelo Supremo Tribunal Federal (e do Superior Tribunal de Justiça), de tal modo que, havendo decisão dos tribunais e juízes inferiores contrária à da Corte, esta deve prevalecer.

Em síntese, por intermédio essencialmente desses institutos, o Supremo Tribunal Federal exerce sua jurisdição constitucional. É o conteúdo das decisões emanadas nessas situações que o coloca em destaque na vida político-social, mormente na solução de conflitos, sendo que, por vezes, essa atividade implica no apontamento de incongruências legislativas e na imposição de determinadas condutas aos Poderes Executivo e Legislativo.

Não obstante, apesar da importância desses instrumentos processuais, notadamente no âmbito da justiça constitucional, o protagonismo do Poder Judiciário foi impulsionado também pela "nova" interpretação constitucional, por meio do que se reconhece que a mera subsunção do fato à norma passou a ser insuficiente para a efetiva concretização das

\footnotetext{
${ }^{207}$ Sobre os sistemas da Common Law e da Civil Law, conferir DAVID, René. Os grandes sistema do direito contemporâneo. São Paulo: Martins Fontes, 2002.

${ }^{208}$ FERREIRA FILHO, Manoel Gonçalves. Curso de direito constitucional. 39. ed. São Paulo: Saraiva, 2013, p. 384.

${ }^{209}$ Cf. RAMOS, Elival da Silva. Ativismo judicial: parâmetros dogmáticos. São Paulo: Saraiva, 2010, p. 294300.
} 
constituições promulgadas no pós-Segunda Guerra Mundial, em que predomina o uso de conceitos abertos ou indeterminados e de princípios.

\subsubsection{A "nova" interpretação constitucional}

A partir de 1988, especialmente nos últimos anos, a Constituição passou a desfrutar, além da supremacia formal, também de efetiva supremacia material, axiológica, potencializada pela abertura do sistema jurídico e pela normatividade dos princípios. Compreendida como uma ordem objetiva de valores, a Constituição se transformou no filtro através do qual se deve ler todo ordenamento jurídico.

Com efeito, pela primeira vez na história brasileira, uma Constituição definiu os objetivos fundamentais do Estado e, ao fazê-lo, orientou a compreensão e interpretação do ordenamento constitucional pelo critério do sistema de direitos fundamentais.

Nesse ambiente, a Constituição passa a ser não apenas um sistema em si - com a sua ordem, unidade e harmonia - mas também um modo de olhar e interpretar todos os demais ramos do Direito. Os valores, os fins públicos e os comportamentos contemplados em seus princípios e regras passam a condicionar a validade e o sentido de todas as normas do direito infraconstitucional. À luz dessas premissas, toda interpretação jurídica é também interpretação constitucional.

Não obstante, Canotilho ressalta que "interpretar a Constituição oferece em geral mais dificuldade do que interpretar as normas de um código civil ou de um código penal”, em razão da "textura aberta das normas constitucionais", da "dimensão política da atividade interpretativa" e do "teoreticismo dos métodos de trabalho". ${ }^{210}$ Celso Ribeiro Bastos corrobora a existência de tal dificuldade na interpretação constitucional, explicando os problemas de interpretação surgem com maior frequência no âmbito constitucional em razão do caráter aberto e amplo da Constituição. ${ }^{211}$

${ }^{210}$ CANOTILHO, Joaquim José Gomes. Direito constitucional e teoria da constituição. 7. ed. Coimbra: Almedina, 2003, p. 1119.

${ }^{211}$ BASTOS, Celso Ribeiro. Hermenêutica e interpretação constitucional. 2. ed. São Paulo: Celso Bastos Editor: Instituto Brasileiro de Direito Constitucional, 1999, p. 53-54. 
Assim, para aplicar as normas constitucionais, o intérprete deve enfrentar a textura aberta e a vagueza dos princípios e dos conceitos jurídicos indeterminados, o que, por um lado, implica em maior dificuldade para determinar seu alcance, e, por outro, permite sua comunicação com a realidade e a evolução do seu sentido. ${ }^{212}$ Como leciona Inocêncio Mártires Coelho:

(...) as normas constitucionais não contêm uma previsão por elementos, limitando-se a enunciar princípios ou critérios gerais de valoração, que não podem exercer a função de premissa maior de silogismo subsuntivo e, por isso, só se tornam operantes depois de densificados e concretizados pelo intérprete-aplicador. ${ }^{213}$

Com efeito, André Ramos Tavares defende a necessidade de abandono da ideia, tradicionalmente aceita, de que a interpretação é um ato praticado sem qualquer subjetividade pelo intérprete. Assim como Celso Ribeiro Bastos ${ }^{214}$ e Gustavo Zagrebelsky, ${ }^{215}$ o autor admite, amplamente, a presença de grande margem de vontade na interpretação, afirmando que a interpretação não é uma atividade descritiva, mas sim construtiva. ${ }^{216}$

Isso porque a Constituição se utiliza de inúmeras cláusulas gerais e conceitos jurídicos indeterminados, e contém uma infinidade de princípios, normas constitucionais hoje reconhecidamente dotadas de imperatividade. Em relação a essas cláusulas gerais e princípios, embora possam existir certezas positivas ou negativas sobre seu significado, é indiscutível que há uma ampla área de penumbra que se presta a valorações que não poderão refugir a algum grau de subjetividade.

Com efeito, as denominadas cláusulas gerais ou conceitos jurídicos indeterminados contêm termos ou expressões de textura aberta, maleáveis, que fornecem um início de significação a ser complementado pelo intérprete, em consideração às circunstâncias do caso concreto. Assim, Luís Roberto Barroso ensina que, "como a solução não se encontra integralmente no enunciado normativo, sua função [do intérprete] não poderá limitar-se à

\footnotetext{
${ }^{212}$ BARROSO, Luís Roberto. Curso de direito constitucional contemporâneo: os conceitos fundamentais e a construção de um novo modelo. 2. ed. São Paulo: Saraiva, 2010, p. 273.

${ }^{213}$ COELHO, Inocêncio Mártires. Interpretação constitucional. 3. ed. São Paulo: Saraiva, 2007, p. 73.

${ }^{214}$ BASTOS, Celso Seixas Ribeiro. Hermenêutica e interpretação constitucional. 3. ed. São Paulo: Celso Bastos Editor, 2003, p. 17

${ }^{215}$ ZAGREBELSKY, Gustavo. Diritto constituzionale: il sistema delle fonti del diritto. 1. ed. v. 1. Torino: Unione Tipografico-Editrice Torinese, 1998, p. 68 e ss.

${ }^{216}$ TAVARES, André Ramos. Curso de direito constitucional. 8. ed. São Paulo: Saraiva, 2010, p. 100.
} 
revelação do que lá se contém; ele [o intérprete] terá de ir além, integrando o comando normativo com a sua própria avaliação.". ${ }^{217}$

No que se refere aos princípios, deve-se ter em vista que, ao contrário das regras, eles não são comandos imediatamente descritivos de condutas específicas, mas sim normas que consagram determinados valores ou indicam fins públicos a serem realizados por diferentes meios. A definição do conteúdo de princípios como o da dignidade da pessoa humana, da razoabilidade, da solidariedade e da eficiência também transfere para o intérprete uma dose importante de discricionariedade. A menor densidade dessas normas impede que se extraia delas, no seu relato abstrato, a solução completa das questões sobre as quais incidem. Também aqui, portanto, impõe-se a atuação do intérprete na definição concreta do seu sentido e alcance.

Desse modo, o Judiciário deixa de ser mero guardião passivo da Constituição, posição que ocupava no Estado Liberal, para tornar-se promotor ativo do que se pode chamar de programaticidade dirigente constitucional, uma vez que lhe é dado interpretar e aplicar as normas constitucionais, sejam elas regras sejam princípios. ${ }^{218}$ Nessa medida, Garcia de Enterría, ao defender que o juiz deve promover uma "construção criativa", formula o conceito de "jurisprudência de princípios" em oposição à "jurisprudência de conceitos", típica do positivismo jurídico clássico, segundo a qual o juiz seria mero autômato aplicador dos dispositivos legais. $^{219}$

Assim, tendo em vista a profunda alteração do conteúdo normativo das constituições, emergiu a necessidade de um novo modo de interpretar as normas constitucionais, pois, os operadores jurídicos e os teóricos do Direito se deram conta de que "as categorias tradicionais da interpretação jurídica não são inteiramente ajustadas para a solução de um conjunto de problemas ligados à realização da vontade constitucional.". ${ }^{220}$ A partir dessa constatação, iniciou-se um processo de elaboração de novos conceitos e métodos de interpretação a que se chamou "nova" interpretação constitucional.

\footnotetext{
${ }^{217}$ BARROSO, Luís Roberto. O novo direito constitucional brasileiro: contribuições para a construção teórica e prática da jurisdição constitucional no Brasil. Belo Horizonte: Fórum, 2013, p. 198.

${ }^{218}$ DANTAS, Miguel Calmon. Constitucionalismo dirigente e pós-modernidade. São Paulo: Saraiva, 2009, p. 355 e ss.

${ }^{219}$ ENTERRÍA, Eduardo Garcia de. Reflexiones sobre la ley e los principios generales del derecho. Editorial Civitas, 1986, p. 132-133. Apud SERRANO, Pedro Estevam Alves Pinto. O desvio de poder na função legislativa. São Pulo: FTD, 1997, p. 113.

${ }^{220}$ BARROSO, Luís Roberto. O novo direito constitucional brasileiro: contribuições para a construção teórica e prática da jurisdição constitucional no Brasil. Belo Horizonte: Fórum, 2013, p. 197.
} 
A hermenêutica tradicional, com suporte na lição de Savigny, era instrumentalizada pelos seguintes elementos: gramatical, histórico, sociológico, sistemático e teleológico. Alertava o autor que tais métodos não eram excludentes, devendo ser aplicados de forma integrada para que se pudesse encontrar o verdadeiro sentido das normas, constitucionais ou infraconstitucionais. Isso porque a interpretação seria um processo unitário e englobaria aquelas quatro operações distintas. ${ }^{221}$

Para fins de uma hermenêutica constitucional voltada para o Estado de Direito concebido como um Estado mínimo, reduzido em suas funções, a interpretação tinha uma orientação de bloqueio - interpretação de bloqueio -, em atenção ao princípio da estrita legalidade. $^{222}$

No entanto, com a passagem do Estado Liberal para o Estado Social, as constituições passaram por profundas modificações, principalmente em razão da constitucionalização dos direitos fundamentais, o que provocou uma alteração do próprio Direito, como ressalta Ruy Barbosa:

(...) a concepção individualista dos direitos humanos tem evoluído rapidamente, com os tremendos sucessos deste século, para uma noção incomensurável nas noções jurídicas do individualismo, restringidas, agora, por uma extensão cada vez maior dos direitos sociais. Já não se vê na sociedade um mero agregado, uma justaposição de unidades individuais acasteladas cada qual no seu direito intratável, mas uma unidade orgânica, em que a esfera do individuo tem por limites inevitáveis, de todos os lados, a coletividade. $\mathrm{O}$ direito vai cedendo à moral, o individuo à associação, o egoísmo à solidariedade humana.

No mesmo sentido, Tercio Sampaio Ferraz Junior se refere a uma "desformalização" da constituição e aponta para a lição de Max Weber acerca da dissolução do formalismo jurídico a partir do advento do Estado Social, que trouxe, com ele, novas exigências materiais por meio dos direitos sociais, as quais se aplicam ainda ao Estado Democrático de Direito:

Ele [Max Weber] previa não só certa disparidade entre as legalidades lógicas próprias do pensamento formal jurídico e os efeitos econômicos visados como também as respectivas expectativas. Surgiam, dizia ele, exigências materiais dos modernos problemas de classe, de um lado, acompanhadas, de outro, de propostas ideológicas jurídicas que se guiavam por critérios valorativos contidos na expressão social do direito. (...) O que Weber tinha em mente talvez pudesse ser esclarecido em termos de uma distinção entre

${ }^{221}$ SAVIGNY, Friedrich Carl von. Sistema del Derecho Romano actual. t. I. Madri: F. Gongóra y Cia. Editores, 1878 , p. 150.

${ }^{222}$ FERRAZ JUNIOR, Tercio Sampaio. Interpretação e estudos da Constituição de 1988. São Paulo: Atlas, 1990, p. 11-12. 
procedimentos interpretativos de bloqueio - hermenêutica tradicional - e procedimentos interpretativos de legitimação de aspirações sociais à luz da constituição. Esta interpretação de legitimação significa que certas aspirações se tornariam metas privilegiadas até mesmo acima ou para além de uma conformidade constitucional estritamente formal. Elas fariam parte, por assim dizer, da pretensão de realização inerente à própria constituição.

Se, no contexto da hermenêutica tradicional (interpretação de bloqueio), pressupunhase que os preceitos constitucionais estatuem princípios e finalidades fundamentais, em relação aos quais o intérprete não pode articular sentidos e objetivos senão aqueles que já estejam reconhecidos desde sempre na própria constituição, a partir do Estado Social, passou-se a exigir a prática de uma interpretação de legitimação, por meio da qual o intérprete está autorizado a articular e qualificar o interesse público, coletivo e individual, postos como um objetivo pelo preceito constitucional, o que implica em uma certa discricionariedade hermenêutica. $^{223}$

No atual Estado Democrático de Direito, a superação dos métodos clássicos da hermenêutica jurídica é ainda mais evidente diante das peculiaridades das normas constitucionais, a saber: (i) sua superioridade hierárquica, confirmada pelos mecanismos de controle de constitucionalidade, (ii) a natureza de sua linguagem, muitas vezes principiológica e abstrata, (iii) o seu conteúdo específico, que abarca normas programáticas, além de simples normas de conduta, e (iv) o seu caráter político, já que representam a juridicização dos valores políticos essenciais da sociedade.

Em tal medida, a nova interpretação constitucional rege-se pelos seguintes princípios, derivados das lições de Konrad Hesse, que defende a existência de uma única disciplina de hermenêutica geral, mas que abarca, como espécie, a hermenêutica constitucional (esta adaptada ao estudo de princípios interpretativos próprios para a compreensão do texto constitucional e suas peculiaridades): ${ }^{224}$ (i) unidade da constituição, ${ }^{225}$ (ii) concordância

\footnotetext{
${ }^{223} \mathrm{O}$ intérprete deve pressupor, nesse caso, que os preceitos constitucionais estão submetidos a certas condições, algumas de ordem normativa estrutural - os preceitos dirigidos à participação e à prestação positiva do Estado Social não são imediatamente realizáveis, devendo o intérprete prover uma identificação dos meios possíveis para a consecução de finalidades, quer sejam eles meios sociais ou técnicos - e outras de ordem jurídicofuncionais - cabe ao intérprete direcionar a configuração da ordem social desejada, a partir da qual se dará o controle de constitucionalidade. Os reguladores dogmáticos de uma interpretação de legitimação são, por isso, um tanto abertos, flexíveis, como é o caso da regra da proporcionalidade. O Estado Social está vinculado à realização de seus objetivos, cabendo ao intérprete considerá-los sob o ponto de vista da sua viabilidade. (FERRAZ JUNIOR, Tercio Sampaio. Interpretação e estudos da Constituição de 1988. São Paulo: Atlas, 1990, p. 14.)

${ }^{224}$ HESSE, Konrad. A interpretação constitucional. Tradução de Inocêncio Mártires Coelho. In: Temas fundamentais de Direito Constitucional. São Paulo: Saraiva, 2009, p. 111-115. Confiram-se também os comentários sobre esses princípios em COELHO, Inocêncio Mártires. Hermenêutica constitucional. In:
} 
prática, ${ }^{226}$ (iii) exatidão funcional (ou conformidade funcional), ${ }^{227}$ (iv) eficácia integradora, ${ }^{228}$ (v) força normativa da constituição, (vi) máxima efetividade ${ }^{229}$ e (vii) interpretação conforme. $^{230}$

A partir da combinação desses princípios, a doutrina discorre sobre alguns métodos de interpretação constitucional, a saber, o método tópico-problemático, o método hermenêuticoconcretizador, o método científico-estrutural e o método normativo-estruturante. ${ }^{231}$

Ao comparar a "velha hermenêutica" e a "nova hermenêutica", Paulo Bonavides afirma que a primeira, respaldada nas lições de Savigny, de inspiração romanista e jusprivatista, parte da legalidade dos Códigos e se afeiçoava ao Direito Privado, enquanto a segunda parte da legitimidade das Constituições e se afeiçoa ao Direito Público. ${ }^{232}$ Resulta que a "velha hermenêutica" servia ao Direito de uma sociedade simples ao passo que a "nova hermenêutica" serve a uma sociedade complexa, saindo da rigidez interpretativa de um Direito em repouso para a flexibilidade de interpretação de um Direito dinâmico. ${ }^{233}$

No contexto de alargamento da democracia, por meio de instrumentos de participação popular, as constituições passam a agregar um "conteúdo material, através dos valores

MARTINS, Ives Gandra da Silva; MENDES, Gilmar Ferreira; NASCIMENTO, Carlos Valder do Nascimento (Coord.) Tratado de direito constitucional. v. 1. São Paulo: Saraiva, 2010, p. 233-242.

${ }^{225}$ A constituição deve ser interpretada como um todo interconectado, preservando-se os valores e decisões fundamentais nela expressos. Dentre estes valores pode-se apontar, principalmente, aqueles elencados nos seus $\operatorname{artigos} 1^{\circ}$ a $4^{\circ}$, que enunciam os fundamentos e os objetivos da República, no âmbito interno, bem como os princípios norteadores de sua atuação no âmbito internacional.

${ }^{226}$ A aplicação deste princípio pressupõe um conflito entre bens protegidos pela Constituição, de modo que, por terem todos a mesma dignidade constitucional (decorrente da unidade da Constituição), devem receber o mesmo grau de proteção, sem que um aniquile ou prevaleça sobre os demais.

227 A interpretação da Constituição não pode ser feita de modo a subverter, alterar ou mesmo perturbar o esquema de organização e repartição das funções/competências entre os poderes constituídos. Decorre diretamente do princípio da unidade da Constituição e do próprio princípio da separação dos poderes, enunciado no artigo $2^{\circ}$ da Carta Magna.

${ }^{228}$ Toda interpretação constitucional deve procurar solucionar os problemas jurídico-constitucionais com base em critérios que favoreçam a integração social e a unidade política, pois o sistema jurídico só se torna viável num Estado em que prevaleça a coesão sociopolítica, e a Constituição busca justamente promover essa coesão.

${ }^{229}$ Esse princípio está diretamente interligado ao princípio da força normativa. Isso porque buscar efetividade nas normas constitucionais pressupõe admiti-las como sendo dotadas de força normativa (como, aliás, todas as normas jurídicas). Esse princípio funcionaria, assim, como um "potencializador" da força normativa. Uma vez reconhecido que as normas constitucionais são dotadas de normatividade (ainda que mínima), cumpre ao intérprete expandir e densificar ao máximo essa normatividade, especialmente se a norma interpretada disser respeito a direitos e garantias fundamentais.

${ }^{230}$ Esse princípio/instrumento deve ser utilizado quando uma norma apresentar um "espaço de decisão", comportando diversas interpretações, umas compatíveis com a Constituição e outras não. Frente a esta situação, o intérprete deve escolher o sentido da norma que melhor se compatibilize com o padrão constitucional, com seus princípios e objetivos e com os direitos e garantias fundamentais.

${ }^{231}$ Para a descrição de cada um desses métodos, cf. COELHO, Inocêncio Mártires. Hermenêutica constitucional. In: MARTINS, Ives Gandra da Silva; MENDES, Gilmar Ferreira; NASCIMENTO, Carlos Valder do Nascimento (Coord.) Tratado de direito constitucional. v. 1. São Paulo: Saraiva, 2010, p. 225-233.

${ }^{232}$ BONAVIDES, Paulo. Teoria do Estado. 9. ed. São Paulo: Malheiros, 2012, p. 368.

${ }^{233}$ BONAVIDES, Paulo. Teoria do Estado. 9. ed. São Paulo: Malheiros, 2012, p. 368. 
substantivos que apontam para uma mudança de status quo da sociedade". ${ }^{234}$ Por essa razão, no Estado Democrático que Direito, a Constituição ocupa papel privilegiado na instrumentalização do Estado na busca dos objetivos contidos no seu texto.

A Constituição de 1988 está alinhada às constituições europeias do pós-guerra e, nessas condições, é um estatuto que traz em seu bojo um conteúdo inovador, legítimo e politicamente justo, porque representa os desejos, os deveres e os sentimentos do cidadão brasileiro. A cidadania não significa apenas a atribuição formal de direitos e deveres às pessoas, mas exige que esses direitos tenham efetividade, que sejam concretizados. Por isso, Paulo Bonavides afirma que o momento não é mais o de declarar direitos, mas de concretizálos. ${ }^{235}$

Nesse cenário, é importante notar a modificação do papel do juiz, o que está diretamente ligado ao entendimento sobre o valor da constituição e da atividade jurisdicional no Estado Democrático de Direito.

Para aqueles que se filiam à corrente substancialista, como o italiano Mauro Cappelletti e os brasileiros Celso Antonio Bandeira de Mello, Eros Roberto Grau, Fábio Konder Comparato e Paulo Bonavides, o constitucionalismo dirigente, que positivou os direitos fundamentais sociais, assumiu papel de absoluta relevância, especialmente no que respeita à jurisdição constitucional. Esses autores valorizam o conteúdo material das constituições, atribuindo-lhes um papel diretivo, cabendo à lei operacionalizar a concretização dos vetores axiológicos que contemplam. Assim, o direito avança em esferas outrora afetas à liberdade política e o Judiciário assume um relevante papel na efetivação da constituição.

Os procedimentalistas, representados especialmente por Jünger Habermas ${ }^{236}$ e por John Hart Ely ${ }^{237}$, acentuam o papel instrumental da constituição, segundo o qual ela estaria primordialmente voltada à garantia de instrumentos de participação democrática e à regulação do "processo" de tomada de decisões, com a consequente valorização da liberdade política inerente à concepção democrática.

Apesar de reconhecerem a penetração de valores substantivos nesse processo, os juristas defendem que a sua importância é meramente secundária, não dirigindo o processo

\footnotetext{
${ }^{234}$ STRECK, Lênio Luis. Jurisdição constitucional e hermenêutica: uma nova crítica do Direito. Porto Alegre: Livraria do Advogado, 2002, p. 128.

${ }^{235}$ BONAVIDES, Paulo. Curso de direito constitucional. 27. ed. São Paulo: Malheiros, 2012, p. 373.

${ }^{236}$ Cf. HABERMAS, Jünger. Democracia e Direito: entre facticidade e validade. v. I. Tradução de Flávio Beno Siebeneichler. Rio de Janeiro: Tempo Brasileiro, 2003.

${ }^{237}$ Cf. ELY, John Hart. Democracy and distrust: a theory of judicial review. 11. ed. Cambridge: Harvard University Press, 1995, p. 88 e ss.
} 
em si. Assim, incumbiria ao Judiciário apenas assegurar a observância desse processo, cabendo a cada geração estabelecer as bases axiológicas sobre as quais se desenvolverá.

Canotilho, referindo-se especificamente ao papel do juiz segundo tais teorias, faz a distinção entre interpretativistas e não interpretativistas. Os primeiros assumem postura próxima à dos procedimentalistas:

(...) consideram que os juízes, ao interpretarem a constituição, devem limitar-se a captar o sentido dos preceitos expressos na constituição ou, pelo menos, nela claramente implícitos. [...] aponta como limites de competência interpretativa a textura semântica e a vontade do legislador. Estes limites são postulados pelo princípio democrático [...]. ${ }^{238}$

Os não interpretativistas, por sua vez, se assemelham aos substancialistas:

(...) defendem a possibilidade e a necessidade de os juízes invocarem a aplicarem valores e princípios substantivos - princípios da liberdade e da justiça - contra actos da responsabilidade do legislativo em desconformidade com o projecto da constituição. [...] A mediação judicial concretizadora desses princípios é uma tarefa indeclinável dos juízes. ${ }^{239}$

Canotilho finaliza concluindo pela impossibilidade de se sustentar o entendimento defendido pelos interpretativistas, uma vez que a constituição é um sistema aberto de “regras/princípios/procedimento". É induvidoso, portanto, que a corrente não interpretativista, defensora de um sentido material da constituição é a mais adequada à efetivação das constituições vigentes nos Estados Democráticos de Direito.

Também para Luís Roberto Barroso, ao juiz não cabe apenas uma função de conhecimento técnico, voltado para revelar a solução contida no enunciado normativo. $\mathrm{O}$ intérprete torna-se coparticipante do processo de criação do Direito, completando o trabalho do legislador, ao fazer valorações de sentido para as cláusulas abertas e realizar escolhas entre soluções possíveis. ${ }^{240}$

Disso decorre, segundo Lênio Luiz Streck, uma nova relação entre os Poderes, onde o Judiciário - ou tribunais constitucionais, onde existem - passa a ocupar maior participação política na administração do Estado. Ocorre um redimensionamento na clássica relação entre

\footnotetext{
238 CANOTILHO, José Joaquim Gomes. Direito constitucional e teoria da constituição. 7. ed. Coimbra: Almedina, 2003, p. 1197.

239 CANOTILHO, José Joaquim Gomes. Direito constitucional e teoria da constituição. 7. ed. Coimbra: Almedina, 2003, p. 1196.

${ }^{240}$ BARROSO, Luís Roberto. O novo direito constitucional: contribuições para a construção teórica e prática da jurisdição constitucional no Brasil. Belo Horizonte: Fórum, 2013, p. 198.
} 
os poderes do Estado, surgindo o Judiciário como uma "alternativa para o resgate das promessas da modernidade, através do deslocamento da esfera de tensão, até então calcada nos procedimentos políticos, para os procedimentos judiciais.". ${ }^{24}$

Com efeito, a Constituição de 1988 contempla extenso rol de direitos fundamentais, os quais devem ser concretizados pelos Poderes constituídos.

Desse modo, diante da inação ou da ação insuficiente dos Poderes Legislativo e Executivo na efetivação desses direitos (diga-se, das normas com textura aberta, dos princípios), resta ao Supremo Tribunal Federal, no exercício do controle de constitucionalidade, a sua interpretação e aplicação. Confira-se, a esse respeito, o entendimento de Enrique Ricardo Lewandowski:

E aí o Supremo passa a decidir quase no vácuo em dos demais poderes, passa a decidir em questões em que os demais poderes ou demonstrem incapacidade, ou inapetência, dada a complexidade das questões, ou até a controvérsia que certas questões suscitam.

Então, o Supremo começou a decidir questões, como as relativas à fidelidade partidária, greve dos servidores públicos, limites das pesquisas científicas, regime jurídico das terras indígenas, uso de algemas, direito de apelar em liberdade (...) .

O que acontece? Isso vem para o Judiciário, e este não pode deixar de prestar a jurisdição. Por isso, a palavra ativismo judicial talvez não seja a mais indicada, porque o Judiciário não busca intervir na realidade política, social e econômica; ele é instado a fazê-lo, e uma vez instado a fazê-lo, deve dar uma solução. ${ }^{242}$

Assim, a nova interpretação constitucional legitima a expansão da jurisdição constitucional. Isso porque o Poder Judiciário passa a ter maior participação na interpretação e especificação das normas de conteúdo aberto, deixando de ser mero guardião passivo, posição que ocupava no Estado Liberal, para tornar-se promotor ativo do que se pode chamar de programaticidade dirigente constitucional. ${ }^{243}$

Mais do que isso, a textura aberta das normas constitucionais, os novos métodos de interpretação constitucional, associados à expansão do controle de constitucionalidade e à ineficiência dos Poderes Legislativo e Executivo, são responsáveis pela consolidação, no

\footnotetext{
${ }^{241}$ STRECK, Lênio Luis. Jurisdição constitucional e hermenêutica: uma nova crítica do Direito. Porto Alegre: Livraria do Advogado, 2002, p. 128.

${ }^{242}$ LEWANDOWSKI, Enrique Ricardo. O protagonismo do Poder Judiciário na era dos direitos. Revista de Direito Administrativo, n. 251, p. 77-85, mai/ago. 2009, p. 83.

${ }^{243}$ DANTAS, Miguel Calmon. Constitucionalismo dirigente e pós-modernidade. São Paulo: Saraiva, 2009, p. 355 e ss.
} 
Brasil, do fenômeno da "judicialização da política", esta entendida como a crescente interferência do Poder Judiciário em questões políticas, o que implica em uma nova dinâmica na separação dos Poderes.

No capítulo seguinte, veremos alguns dos assuntos decididos pelo Supremo Tribunal Federal nos últimos anos, assim como as críticas à Corte, em razão de um suposto abuso na atuação em casos que envolvem questões políticas. Por fim, verificaremos o impacto dessas decisões sobre a relação entre os Poderes Legislativo e Judiciário, sob o aspecto da separação dos Poderes. 


\section{O SUPREMO TRIBUNAL FEDERAL NO PÓS-88}

\subsection{Competências do Supremo Tribunal Federal na Constituição de 1988}

Foi apenas com o advento da Constituição de 1988 que o Judiciário pôde efetivamente ocupar espaço de prestígio no cenário político brasileiro, chegando, inclusive, a se destacar em relação aos Poderes Legislativo e Executivo. O âmbito em que mais se fez sentir a expansão do Poder Judiciário foi o da jurisdição constitucional, tendo em vista a consolidação do sistema de controle de constitucionalidade, o advento de uma "nova" interpretação constitucional e a constitucionalização dos direitos que, dentre outros fatores.

Nessa medida, cabe uma breve elucidação acerca das funções e competências que a Constituição de 1988 atribuiu ao Supremo Tribunal Federal, passando-se posteriormente à apresentação de duas questões ligadas ao desempenho da função política pela Corte, a "judicialização da política" e o "ativismo judicial”, bem como à apresentação de alguns julgados em que se teria verificado um exagero na intervenção do Supremo no desempenho de sua função política.

A criação do Supremo Tribunal Federal data dos primeiros anos da República. Com a queda da Monarquia e a instauração do regime republicano no Brasil, o Governo Provisório precisou criar novas instituições mais condizentes com a nova conjuntura. Dentre elas, era necessário definir aquela que funcionaria como a última instância para a resolução de conflitos públicos e privados, tendo em vista que essa função, até então, era desempenhada pelo Imperador. $^{244}$

Assim, a Constituição de 1988, ao organizar o Poder Judiciário, reservou ao Supremo Tribunal Federal, modelado na Suprema Corte norte-americana, a revisão de decisões das

\footnotetext{
${ }^{244}$ É certo que na Constituição imperial de 1824, já havia previsão de um órgão de cúpula do Poder Judiciário, o Supremo Tribunal de Justiça. Esse Tribunal, embora tivesse caráter político, não era responsável por velar pela constitucionalidade das leis. Isso porque “(...) permitir a sindicabilidade judicial nos atos normativos seria um atentado ao princípio da separação de Poderes, então claudicante, diga-se, em face do Poder Moderador. E, em face da estrutura constitucional da época, se fosse atribuir a algum poder essa missão, o titular dessa tarefa seria o Moderador, que era a suprema inspeção da Nação sobre os demais poderes." Cf. ALVES JR., Luís Carlos Martins. O Supremo Tribunal Federal nas Constituições brasileiras. Belo Horizonte: Mandamentos, 2004, p. 128.
} 
cortes de apelação todas as vezes que houvesse violação de direito, o julgamento de conflitos entre autoridades judiciais e a administração federal, entre União e Estados, ou entre os próprios Estados. Também foram transferidos a ele os poderes judiciais que, no Império, eram de alçada do Conselho de Estado, de modo que suas atribuições iniciais acabaram se ampliando. O Supremo Tribunal Federal se tornou a instituição responsável pela avaliação da constitucionalidade dos atos do Legislativo e do Executivo, e pela garantia dos direitos constitucionais do cidadão. ${ }^{245,246}$

Desde então, ao longo da história constitucional, pouco foram modificadas as competências do Supremo Tribunal Federal, sendo certo, no entanto, que, ao lado do controle de constitucionalidade difuso, a Corte passou a realizar também o controle concentrado, de inspiração austríaca.

Especificamente quanto à sua competência, a Constituição de 1934, denominando-o Corte Suprema, apenas acrescentou-lhe o conhecimento de mandados de segurança contra atos do Presidente ou de Ministros de Estado e o julgamento da representação interventiva proposta pelo Procurador Geral da Repúbica para declaração de inconstitucionalidade de intervenção federal.

A Constituição de 1937 voltou a denominá-lo Supremo Tribunal Federal e permitiu o Presidente da República anular decisões que não fossem de seu agrado ou excluir, compulsoriamente, por aposentadoria ou prisão, qualquer Ministro do Supremo. Portanto, o papel da Corte, na prática, resumiu-se ao julgamento de questões de direito privado ou criminal, desde que não estivessem na alçada de interesse do Governo.

A Constituição de 1946, em sua redação originária, embora tenha recolocado o Supremo Tribunal Federal como árbitro final do contencioso constitucional, quase não inovou

\footnotetext{
${ }^{245}$ Remonta a esse período histórico o desenvolvimento da doutrina do habeas corpus, amplamente defendida por Rui Barbosa. Grande parte do conflito havido entre o Supremo e o Poder Executivo relacionava-se à insatisfação do Presidente Floriano Peixoto em relação à concessão de habeas corpus em favor de presos políticos. Para detalhes, cf. COSTA, Emília Viotti da. O Supremo Tribunal Federal e a construção da cidadania. 2. ed. São Paulo: Editora UNESP, 2006, p. 30 e ss.

${ }^{246}$ Emília Viotti da Costa esclarece que o papel mais importante do Supremo nos primeiros cinco anos da República foi a defesa das liberdades civis e o estabelecimento da jurisprudência - defendeu o direito de indenização aos proprietários em caso de desapropriação, afirmou a incompetência da Justiça Militar para julgamento de civis, declarou ilegal a prisão a que estavam sujeitos os pacientes recrutados à força para o Exército, defendeu a imunidade parlamentar, definiu os limites do estado de sítio e determinou a libertação de presos ilegalmente detidos. Não obstante, Luís Carlos Martins Alves Jr. Ressalta que quanto às demandas sociais e econômicas, a Constituição, o regime político e o próprio Supremo Tribunal mantiveram-se insensíveis aos novos reclamos da classe proletária. Cf., respectivamente, COSTA, Emília Viotti da. O Supremo Tribunal Federal e a construção da cidadania. 2. ed. São Paulo: Editora UNESP, 2006, p. 24 e 35 e ALVES JR., Luís Carlos Martins. O Supremo Tribunal Federal nas Constituições brasileiras. Belo Horizonte: Mandamentos, 2004, p. 128.
} 
em sua competência. Apenas em 1965, com a edição da Emenda Constitucional $\mathrm{n}^{\circ}$ 16, foi instituída a representação de inconstitucionalidade de lei ou ato normativo, federal ou estadual, a ser encaminhada pelo Procurador-Geral da República ao Supremo Tribunal Federal. Desta forma, foi inaugurado o controle concentrado de constitucionalidade brasileiro, como referido anteriormente.

A Constituição de 1967, modificada pela Emenda Constitucional n. 1, de 17 de outubro de 1969, formalmente manteve as competências anteriores do Supremo Tribunal Federal, incluindo a representação de inconstitucionalidade e criando o instituto da avocatória, que consistia na possibilidade de o Supremo, mediante pedido do Procurador-Geral da República, abduzir as causas processadas perante quaisquer juízos ou Tribunais em caso de perigo de grave lesão à ordem, à saúde, à segurança ou às finanças públicas, para que se suspendessem os efeitos da decisão proferida e para que o conhecimento geral da causa fosse devolvido ao Supremo.

Até a edição do Ato Institucional n. 5, de 13 de dezembro de 1968, que recrudesceu a ditadura militar brasileira, o Supremo decidiu inúmeros casos, exercendo a jurisdição constitucional em defesa de liberdades. Após, em 1969, o Governo aposentou compulsoriamente três Ministros da Corte e dois outros se aposentaram - formalmente, sem a intervenção do Executivo -, esvaziando a força jurisdicional do Supremo, que não gozava de independência para julgamento.

Por fim, a Constituição de 1988, que restaurou o Estado de Direito no Brasil e promoveu a reabertura democrática, manteve a estrutura do Supremo Tribunal Federal herdada do passado, ${ }^{247}$ de tal modo que os artigos que hoje enumeram as suas competências reproduzem muitas das igualmente presentes nas Constituições anteriores. Não se olvida, todavia, que houve notória ampliação de sua competência no terreno da jurisdição constitucional, com a criação do mandado de injunção e com o alargamento do rol de autoridades e instituições autorizadas à propositura da ação direta de inconstitucionalidade, inclusive para casos de omissão.

Dispõe a Constituição de 1988 que o Supremo Tribunal Federal - composto de onze Ministros escolhidos dentre cidadãos brasileiros natos com mais de trinta e cinco e menos de sessenta e cinco anos de idade, com notável saber jurídico e reputação ilibada, nomeados pelo Presidente da República, após aprovação da escolha pela maioria absoluta do Senado Federal

${ }^{247}$ COSTA, Emília Viotti da. O Supremo Tribunal Federal e a construção da cidadania. 2. ed. São Paulo: Editora UNESP, 2006, p. 185. 
-, tem como competência precípua a guarda da Constituição (artigo 102, caput), competência esta que se classifica em originária, incluído aqui o controle de constitucionalidade concentrado, e recursal, esta subdividida, por sua vez, em ordinária e extraordinária (artigos 102 e 103).

No que toca ao controle de constitucionalidade, originariamente, compete ao Supremo julgar: a ação direta de inconstitucionalidade e a ação declaratória de constitucionalidade; o mandado de injunção, quando a elaboração da norma regulamentadora for atribuição do Presidente da República, do Congresso Nacional, da Câmara dos Deputados, do Senado Federal, das Mesas de uma dessas Casas Legislativas, do Tribunal de Contas da União, de um dos Tribunais Superiores, ou do próprio Supremo Tribunal Federal; a arguição de descumprimento de preceito fundamental; e a ação direta de inconstitucionalidade por omissão.

Também, em sede de competência originária, exemplificativamente, cabe ao Supremo Tribunal Federal: o julgamento de infrações penais comuns, crime de responsabilidade, habeas corpus, habeas data, tudo isso em razão do foro privilegiado concedido a alguns membros dos órgãos do Poder Executivo federal, do Congresso Federal, do Tribunal de Contas da União e do próprio Supremo Tribunal Federal; o litígio entre Estado estrangeiro ou organismo internacional e a União, o Estado, o Distrito Federal ou o Território; as causas e os conflitos entre a União e os Estados, a União e o Distrito Federal, ou entre uns e outros; a extradição solicitada por Estado estrangeiro; a reclamação para a preservação de sua competência e garantia da autoridade de suas decisões; a ação em que todos os membros da magistratura sejam direta ou indiretamente interessados, e aquela em que mais da metade dos membros do tribunal de origem estejam impedidos ou sejam direta ou indiretamente interessados; e as ações contra o Conselho Nacional de Justiça e contra o Conselho Nacional do Ministério Público.

Em grau recursal extraordinário, cumpre ao Supremo julgar as causas decididas, em única ou última instância, quando a decisão recorrida contrariar dispositivo desta Constituição, declarar a inconstitucionalidade de tratado ou lei federal, julgar válida lei ou ato de governo local contestado em face desta Constituição, ou julgar válida lei local contestada em face de lei federal. Por sua vez, no âmbito da competência recursal ordinária, cabe a ele julgar o habeas corpus, o mandado de segurança, o habeas data e o mandado de injunção decididos em única instância pelos Tribunais Superiores, se denegatória a decisão, e o crime político. 
Por fim, mencione-se a competência do Supremo Tribunal Federal de aprovar súmulas com efeito vinculante em relação aos demais órgãos do Poder Judiciário e à administração pública direta e indireta, nas esferas federal, estadual e municipal, bem como proceder à sua revisão ou cancelamento, na forma estabelecida em lei (artigo 103-A).

O conjunto dessas competências alçou o Supremo da posição de simples Tribunal de jurisdição ordinária para, também, de uma Corte Constitucional. Essa dualidade se acentuou a partir de 1988, não apenas em razão da criação de novos instrumentos de acesso ao Supremo Tribunal Federal, mas também por conta da constitucionalização de direitos relacionados a diversos temas, tais como família, educação, saúde, economia, meio ambiente, e pela previsão inédita da inafastabilidade do controle judicial (artigo $5^{\circ}, \mathrm{XXXV)}$.

De fato, segundo Rogério Bastos Arantes, não se pode ignorar que, após a Constituição de 1988, o Poder Judiciário passou a ser "fato condicionante fundamental" do processo político.

Basta uma simples retrospectiva dos principais conflitos entre poderes do Estado, e destes com a sociedade, nos últimos anos, para constatar que a reorganização constitucional de 1988 colocou o Judiciário na difícil tarefa de posição de árbitro do jogo político entre estes importantes contendores. ${ }^{248}$

E, naturalmente, a relevância do órgão de cúpula do Judiciário foi ampliada de forma mais evidente do que a dos demais juízes e tribunais devido ao controle de constitucionalidade.

Para Alexandre de Moraes, a Justiça constitucional, exercida também pelo Supremo Tribunal Federal, possui, geralmente, cinco grandes ramos de competência: controle de constitucionalidade das leis e atos normativos do Poder Público; proteção aos direitos fundamentais; controle das regras da democracia representativa (eleições) e participativa (referendos e plebiscitos); controle do bom funcionamento dos poderes públicos e da regularidade no exercício de suas competências constitucionais; e equilíbrio da federação.

Embora o Supremo Tribunal Federal seja órgão do Poder Judiciário e, por isso, desempenhe, por excelência, a função jurisdicional, dentre as competências constitucionais da

\footnotetext{
${ }^{248}$ ARANTES, Rogério Bastos. Judiciário e política no Brasil. São Paulo: Editora Sumaré, 1997, p. 24. Apud PAIXÃO, Leonardo André. Função política do Supremo Tribunal Federal. 2007. 258 p. Tese (Doutorado) Faculdade de Direito, Universidade de São Paulo, São Paulo, 2007, p. 172.
} 
Corte, é possível diferenciar aquelas que representam o desempenho de função meramente jurisdicional e aqueles que representam o exercício de função política. ${ }^{249}$

Por exemplo, é parte da função meramente jurisdicional ou administrativa do Tribunal, por exemplo, o julgamento de determinadas autoridades em infrações penais comuns (artigo 102 , I, $b$ e $c$ ). Essa competência poderia ser exercida por qualquer outra órgão jurisdicional, não fosse a expressa opção do constituinte por conferir a tais autoridades o benefício de serem julgados originariamente pelo Supremo Tribunal Federal.

No que se refere à função política, cumpre, primeiro, apresentar a definição decantada por Leonardo André Paixão a partir, em especial, das lições de Marcello Caetano, Karl Loewenstein e Canotilho. Trata-se a função política da

(...) atividade que órgãos instituídos pela Constituição exercem no âmbito de sua competência, tendo por objetivo preservar a sociedade política, promover o bem comum, e que consiste em determinar, mediante a livre interpretação de normas constitucionais, o que é o interesse público e quais são os meios necessários à sua implementação. ${ }^{250}$

Em um ambiente democrático, o exercício da função política é atribuído preponderantemente aos órgãos constitucionais integrados por representantes escolhidos e responsáveis perante a opinião pública (Poderes Executivo e Legislativo, em suma), podendo ser praticado também pelo eleitorado, quando é chamado a deliberar.

Também aos Tribunais encarregados da tutela da Constituição é possível o exercício de funções de natureza política, conforme se verifica das lições de Loewenstein, Burdeau, e Jorge Miranda.

Isso porque, para Loewenstein, cumpre aos tribunais exercer função de determinar as decisões políticas (policy determination) quando interpretam a constituição no que se refere aos relacionamentos entre União e Estados-membros, à proteção dos direitos fundamentais e à apreciação, à luz da Constituição, dos atos dos demais órgãos detentores do poder, agindo

\footnotetext{
249 Jorge Miranda vislumbra a existência de dois sentidos distintos para a expressão "função do Estado". No primeiro, função como tarefa, significa uma incumbência do Estado, algo por fazer, correspondente a certa necessidade coletiva, e traduz um princípio ou uma tentativa de legitimação do exercício do poder. O termo quase se confunde com o objetivo e a finalidade do Estado. No segundo sentido, função como atividade, ela corresponde aos atos que o Estado constante e repetidamente desenvolve, em harmonia com as regras que o condicionam e conformam. Cf. MIRANDA, Jorge. Funções do Estado. Revista de Direito Administrativo, Rio de Janeiro, v. 189, p. 148. Neste trabalho, adotamos o segundo sentido indicado por Jorge Miranda, de função como atividade.

${ }^{250}$ PAIXÃ̃, Leonardo André. Função política do Supremo Tribunal Federal. 2007. 258 p. Tese (Doutorado) Faculdade de Direito, Universidade de São Paulo, São Paulo, 2007, p. 51 e ss.
} 
como árbitro em conflito que os envolver. ${ }^{251}$ Burdeau diz que o Conselho Constitucional francês equipara-se ao Parlamento e ao Governo quando atua como legislador negativo, declarando a inconstitucionalidade de um projeto de lei. ${ }^{252}$ Por sua vez, Jorge Miranda considera que o Tribunal Constitucional exerce função política tanto em razão de sua relação direta com a Constituição, quanto em razão do controle realizado sobre os órgãos que exercem função política, estando no mesmo nível destes. ${ }^{253}$

Segundo Leonardo Paixão, a função política nos Tribunais diz respeito especialmente a quatro temas: separação de poderes, federalismo, reconhecimento dos direitos fundamentais e controle do funcionamento das instituições democráticas.

Desse modo, dentre as competências do Supremo que refletem o exercício dessa função estão as diversas modalidades que conduzem ao controle de constitucionalidade e o julgamento de conflitos entre órgãos de soberania (órgão legislativo contra executivo, órgão executivo contra o próprio Supremo ou entre este e órgão legislativo). Como lembra o exMinistro do Supremo Tribunal Federal, José Neri da Silveira, não há dúvidas de que "no controle sobre os atos do Legislativo e do Governo, evidencia-se o caráter político de que está investido o Judiciário no desempenho da competência para proclamar a inconstitucionalidade ou invalidade desses atos.". 254

Ainda, mencione-se o desempenho de função política por meio do julgamento de conflitos entre a União e Estados-membros, no que se refere à repartição de competências estabelecidas pela Constituição; do reconhecimento (ou não) de um direito fundamental em determinada situação concreta, ocasião em que a Corte fixa o exato alcance da norma constitucional, o que se traduz em exercício de função política porque se relaciona diretamente com a definição do interesse público; e, por fim, do controle sobre as instituições democráticas, ao estabelecer regras da disputa eleitoral, ao decidir um caso, definindo em que consiste o interesse público na concretização da democracia.

Nesse passo, fica evidente que a Constituição de 1988 estimulou o desempenho da função política pelo Supremo Tribunal Federal, especialmente no que se refere à resolução de litígios que envolvem desde questões relacionadas aos direitos de liberdade a questões de

\footnotetext{
${ }^{251}$ LOEWENSTEIN, Karl. Teoría de la Constitución. 2. ed. Tradução de Alfredo Gallego Anabitarte. Barcelona: Ariel, 1976, p. 55-56.

${ }^{252}$ BURDEAU, Georges. Remarques sur la classification des fonctions étatiques. Revue du Droit Public, Paris, n. 60, p. 202-228, 1945, p. 214.

${ }^{253}$ MIRANDA, Jorge. Funções do Estado. Revista de Direito Administrativo, Rio de Janeiro, v. 189, p. 148.

${ }^{254}$ PAIXÃO, Leonardo André. Função política do Supremo Tribunal Federal. 2007. 258 p. Tese (Doutorado) Faculdade de Direito, Universidade de São Paulo, São Paulo, 2007, p. 72
} 
biodireito, aborto, políticas públicas, processo eleitoral, união homoafetiva entre outros. Isso se deve, repita-se, ao amplo catálogo de direitos apostos na Constituição de 1988 e ao aumento das possibilidades de reivindicação judicial desses direitos.

Não se questiona, portanto, que o Supremo Tribunal Federal assumiu relevante papel a partir da Constituição de 1988, como muito bem destacou o ex-Ministro Sepúlveda Pertence no plenário da Corte, pouco tempo antes da sua promulgação:

Hoje, nenhuma ordem constitucional se pode reduzir à estrutura de poderes,
que reciprocamente se controlem, e ao plexo de normas voltadas unicamente
à contenção do Estado, em maior ou menor grau: toda Constituição
contemporânea - de modo especial, mas não exclusivamente, as do mundo
subdesenvolvido - veicula um projeto de transformação da sociedade,
centrado, quase necessariamente, no objetivo de redução da iniquidade da
distribuição dos bens da vida. ${ }^{255}$.

Com efeito, é amplamente reconhecido pela doutrina o caráter político do desempenho de parte das competências jurisdicionais do Supremo Tribunal Federal, quando relacionadas aos temas de separação de Poderes, reconhecimento de direitos fundamentais, federalismo e controle do funcionamento das instituições democráticas. No entanto, a atuação da Corte quanto a esses temas tem suscitado o debate de duas questões de ressonância mundial, a "judicialização da política" e o "ativismo judicial”, assim como forte crítica, suscitada pelo questionamento acerca da legitimidade democrática da Corte para rever decisões políticas dos demais Poderes, o que implicaria em suposta violação ao princípio da separação de Poderes.

3.2. A "judicialização da política”, o "ativismo judicial” e a jurisprudência do Supremo Tribunal Federal

No contexto de expansão da função política do Supremo Tribunal Federal, vêm à tona duas questões a ela vinculadas, a "judicialização da política" e o "ativismo judicial". Com efeito, na última década, tornou-se cada vez mais recorrente a utilização desses termos para referir-se a determinadas posturas do Supremo em casos que envolvem questões políticas.

${ }^{255}$ COSTA, Emilia Viotti da. O Supremo Tribunal Federal e a construção da cidadania. 2. ed. Bauru: UNESP, 2006, p. 188. 
Em grande parte das vezes, tais referências se inserem no contexto de críticas a um suposto exagero da Corte no desempenho de sua função política, o que ensejaria indesejável interferência na esfera dos demais Poderes, violando, assim, o princípio democrático e de separação de Poderes.

Embora nos pareça que o ponto nevrálgico dessa discussão seja o ativismo judicial, cumpre esclarecer, primeiramente do que se trata a judicialização da política, para, depois disso, apresentar alguns julgados em que o Supremo Tribunal Federal teria atuado de forma "ativista".

A expressão judicialização da política foi cunhada por Torbjörn Vallinder e examinada com profundidade também por Neal Tate. ${ }^{256}$ Os autores afirmam que o fenômeno está relacionado aos efeitos do Poder Judiciário no processo decisório nas democracias contemporâneas, podendo ter dois significados principais:

1. the process by which courts and judges come to make or increasingly to dominate the making of public policies that had previously been made (or, it is widely believed, ought to be made) by other governmental agencies, especially legislatures and executives, and

2. the process by which nonjudicial negotiating and decision-making forums come to be dominated by quasi-judicial (legalistic) rules and procedures. ${ }^{257}$

Segundo Vallinder e Tate, a judicialização da política está inserida no contexto da expansão do protagonismo judicial, movimento que se iniciou nos Estados Unidos da América e, posteriormente, se dissipou para outros países da América do Norte e do Sul, da Europa Ocidental e Oriental, e até mesmo da Ásia, como é o caso da Índia e das Filipinas. ${ }^{258}$

A expansão do Poder Judiciário nas democracias contemporâneas resulta do desenvolvimento histórico das instituições democráticas e está associada ao fim do comunismo no Leste Europeu, à hegemonia dos Estados Unidos, que propiciou a difusão do

\footnotetext{
${ }^{256}$ A conceituação da judicialização da política foi realizada por Torbjörn VALLINDER em The judicialization of politics. A world-wide phenomenon: introduction. International Political Science Review / Revue internationale de science politique, v.15, n. 2, pp. 91-99, Apr. 1994. Posteriormente, em 1995, juntamente com Neal C. TATE, produz nova obra, tratando com maior profundidade sobre questões relacionadas à judicialização da política, a saber, The global expansion of judicial power. New York: New York University Press, 1995.

${ }^{257}$ TATE, Neal; VALLINDER, Torbjörn. The global expansion of judicial power. New York: New York University Press, 1995, p. 28. Em tradução livre: "1. o processo pelo qual as cortes e os juízes passam a elaborar, ou crescentemente dominar a elaboração, de políticas publicas que haviam sido previamente elaboradas (ou, como amplamente se acredita, deveriam ter sido elaboradas) por outras agências governamentais, especialmente ligadas ao Legislativo e ao Executivo, e 2. o processo pelo fóruns de negociação extrajudicial e de tomada de decisão passam a ser dominados por regras e procedimentos quasi judiciais (legalistas)."

${ }^{258}$ TATE, Neal; VALLINDER, Torbjörn. The global expansion of judicial power. New York: New York University Press, 1995.
} 
sistema norte-americano de revisão judicial entre as novas democracias, e também à cultura dos direitos humanos disseminada na Europa.

Dentre os países atingidos pelo fenômeno da judicialização da política, os autores identificaram um mesmo padrão político, a saber, uma descrença maior nos órgãos dos Poderes Executivo e Legislativo do que nos juízes. Citam, ainda, a corrupção como fator para essa descrença, pois, mesmo que se saiba que todos os três Poderes estão sujeitos à corrupção, uns estão mais do que os outros, sugerindo que o Poder Judiciário seria menos corrupto que os demais. $^{259}$

Seguindo essa mesma linha de raciocínio, John Ferejohn aponta duas causas principais para a consolidação da judicialização da política: a fragmentação de poder na arena política (Legislativo e Executivo), do que decorreu a busca pelo Judiciário, e a confiança nas Cortes para a proteção de um grande número de valores contra o abuso político. ${ }^{260}$

Ou seja, como se vem defendendo neste trabalho, a ampliação do campo de atuação do Poder Judiciário, principalmente no que se refere a questões políticas, está relacionada, dentre outros, com a descrença popular nos Poderes Legislativo e Executivo, o que redunda numa larga utilização da revisão judicial. Mas não só, também é possível afirmar que a própria ideia de constitucionalismo e de previsão de questões políticas na Constituição permitiram que o Judiciário passasse a enfrentar qualquer questão política como sendo uma questão constitucional.

\footnotetext{
259 TATE, Neal; VALLINDER, Torbjörn. The global expansion of judicial power. New York: New York University Press, 1995, p. 3.

${ }^{260}$ Sobre as duas causas referidas, veja-se, conforme tradução livre da autora, a partir do texto original: "A primeira [causa] é uma crescente fragmentação do poder dentro das instâncias políticas, a qual limita a sua capacidade de legislar, ou de ser o local em que a política é efetivamente formulada. Eu chamarei isto de a hipótese de fragmentação. Quando as instâncias políticas não podem agir, as pessoas em busca de resolução de conflitos tenderão a gravitar para instituições das quais possam obter soluções; as cortes (e os processos legais a elas associados) frequentemente oferecem tais fóruns. Ao menos nos Estados Unidos, com seu sistema de "checked legislative powers", um Legislativo dividido não pode facilmente impedir as cortes de elaborar políticas - até mesmo políticas relativamente impopulares. A segunda causa é mais nebulosa, mas talvez a mais importante. É o sendo que de as cortes (ao menos determinadas cortes) podem ser confiadas para proteger uma ampla gama de valores importantes contra potenciais abusos políticos. Chamemos isto de a hipótese de direitos. A ideia é que, enquanto as cortes começaram a proteger direitos e liberdades individuais adicionalmente a direitos de propriedade, a oposição a um papel judicial expansivo diminuiu. Nos Estados Unidos, esta mudança da proteção de direitos econômicos para liberdades individuais e direitos civis foi anunciada pela Corte Suprema em Carolene Products. Na Europa durante o pós-guerra, esta mudança aguardou o desenvolvimento de novas cortes - os tribunais constitucionais - as quais foram confiadas explicitamente com a proteção de uma ampla gama de direitos humanos. Em ambos os casos, o encorajamento de um jurisprudência que ofereceu proteção para uma ampla gama de direitos e valores humanos, e o crescimento de cortes capazes de dar vida a tais valores, foi parcialmente devidos às pessoas e aos seus Legislativos." FEREJOHN, John. Judicializing politics, politicizing law. Law and Contemporary Problems, Durham, v. 65, n. 3, p. 41-68, Summer. Disponível em: http://www.law.duke.edu/journals/65LCPFerejohn. Acesso em: 15 dez. 2013.
} 
$\mathrm{Na}$ doutrina pátria, Eduardo Cambi afirma que o direito constitucional judicializou a política, porquanto a política, representada pelos conflitos sociais e pelos direitos fundamentais, historicamente sonegados, passou a ser um de seus temas recorrentes, viabilizando uma relação de complementaridade entre os campos político e jurídico. ${ }^{261}$

Ainda com relação ao conteúdo da judicialização da política, Vallinder e Tate afirmam que esse fenômeno pode se apresentar de diversas formas. A mais evidente é a revisão judicial de atos dos Poderes Legislativo e Executivo, denominada judicialization from without. Em um contexto mais difuso, os autores distinguem também a judicialization from within, referente à introdução ou expansão de suporte judicial ou de procedimentos judiciais no Executivo (como nos casos de tribunais e/ou juízes administrativos) e no Legislativo (como é o caso das Comissões Parlamentares de Inquérito).

Apesar de Tate identificar um rol geral de condições necessárias ou facilitadoras ao surgimento do processo de judicialização da política, ${ }^{262}$ ressalta que esse fenômeno não possui uma moldura rígida, de modo que sua manifestação varia segundo as peculiaridades de cada país, tais como a estrutura institucional, a formação histórica e a configuração da Constituição.

Também em análise sobre a crescente transferência de poder das instituições representativas para as instituições judiciais, Ran Hirschl esclarece que a judicialização da política é uma espécie de conceito "guarda-chuva", que abriga três processos interrelacionados.

Em seu nível mais abstrato, a judicialização da política significa a expansão do discurso legal - jargões, regras e procedimentos - para a esfera política e para os fóruns de decisões políticas. Nessa medida, a judicialização é inerente à captura das relações sociais e culturais pelas leis, o que se deve ao aumento da complexidade e diversidade das modernas

\footnotetext{
${ }^{261}$ CAMBI, Eduardo. Neoconstitucionalismo e neoprocessualismo: direitos fundamentais, políticas públicas e protagonismo judiciário. São Paulo: RT, 2009, p. 211.

${ }^{262}$ São elas: (i) institucionalização de uma ordem democrática; (ii) separação entre os Poderes estatais e a independência do Poder Judiciário; (iii) universalização do acesso à justiça; (iv) existência de uma Constituição que explicite direitos e valores, os quais possam ser invocados em defesa dos indivíduos e grupos que se sintam lesados pela vontade da maioria; (v) uso dos tribunais por grupos minoritários de interesse para a realização de seus direitos; (vi) uso dos tribunais pelos grupos de oposição para controlar as deliberações majoritárias na arena política; (vii) ineficácia das instâncias majoritárias de formação da vontade política (resultante da ausência e/ou insuficiência das políticas públicas geradas nas arenas políticas e da debilidade dos partidos políticos em governar com a maioria do Parlamento, gerando, com isso, uma crise de governabilidade e uma espécie de paralisia do processo decisório, que é transferido para o Poder Judiciário via demandas judiciais); e (viii) delegação pelas instituições majoritárias, em alguns casos, do custo político de uma decisão polêmica ao Poder Judiciário. (TATE, Neal; VALLINDER, Torbjörn. The global expansion of judicial power. New York: New York University Press, 1995, p. 28-36)
} 
sociedades, bem como da expansão de Estados modernos de bem-estar social, com suas inúmeras agências regulatórias. Hirschl denomina esse tipo de judicialização de judicialization of social relations. ${ }^{263}$

Em um segundo nível, mais concreto, o fenômeno representa o aumento da responsabilidade do Judiciário em decidir sobre políticas públicas, vinculadas a direitos garantidos constitucionalmente, o que acaba por redefinir os próprios limites dos demais Poderes políticos. Esse segundo tipo de judicialização está focado, principalmente, na justiça procedimental e formal dos processos decisórios, e é iniciado, na maior parte das vezes, por meio de processos judiciais, por isso, Hirschl o denomina judicialization from below. ${ }^{264}$

Por fim, o terceiro tipo de judicialização é denominado de política pura ou de política macro (judicialization of mega-politics), que seria a transferência às Cortes de questões de natureza puramente política e de grande importância para a sociedade, como, por exemplo, sobre legitimidade do regime político e sobre identidade coletiva que define (ou divide) toda a política. $^{265}$ Trata-se da judicialização de questões, por exemplos, relativas ao processo eleitoral ou às políticas econômicas adotadas pelo Poder Executivo. Essas questões expandem os limites da Corte na interferência em questões políticas, extrapolando os temas de direitos constitucionais e federalismo, do que resulta a transformação das Supremas Cortes em parte do aparato estatal de policy-making.

Basicamente, a diferença entre o segundo e o terceiro tipo de judicialização, segundo Hirschl, é de que, no terceiro tipo, as questões levadas à Corte são puramente políticas, no sentido de envolverem juízo de conveniência e oportunidade, próprio do Legislativo e do Judiciário. Aqui, o Judiciário estaria efetivamente extrapolando os limites constitucionais da revisão judicial, porque estaria decidindo sobre questões que não estão pré-inscritas na constituição. $^{266}$

\footnotetext{
${ }^{263}$ HIRSCHL, Ran. The New Constitutionalism and the Judicialization of Pure Politics Worldwide. Fordham Law Review, v. 75, n. 2, 2006, p. 724-725. Disponível em: http://ssrn.com/abstract=951610. Acesso em: 04 dez. 2013.

${ }^{264}$ HIRSCHL, Ran. The New Constitutionalism and the Judicialization of Pure Politics Worldwide. Fordham Law Review, v. 75, n. 2, 2006, p. 725. Disponível em: http://ssrn.com/abstract=951610. Acesso em: 04 dez. 2013.

${ }^{265}$ HIRSCHL, Ran. The New Constitutionalism and the Judicialization of Pure Politics Worldwide. Fordham Law Review, v. 75, n. 2, 2006, p. 723. Disponível em: http://ssrn.com/abstract=951610. Acesso em: 04 dez. 2013.

${ }^{266}$ Veja-se trecho explicativo de Ran Hirschl acerca do que se pode entender como questão "política", segundo tradução livre da autora a partir do texto original: "Mas a diferença entre o segundo e o terceiros nível de políticas judicializadas vai além da questão sobre a evidência política. Ela depende de nossa conceptualização sobre o "político." O que conta como uma decisão "política" não é uma questão fácil de responder. Uma decisão política deve afetar as vidas de muitas pessoas. Entretanto, muitos casos que não são puramente políticos (p.ex.,
} 
Nesse sentido, é possível relacionar a judicialização da política ao "novo estatuto dos direitos fundamentais e à superação do modelo de separação dos poderes do Estado, o que provoca uma ampliação dos poderes de intervenção dos tribunais na arena política", especialmente por meio da participação nos processos de formulação ou implementação de políticas públicas. $^{267}$

Na doutrina brasileira, Débora Maciel e Andrei Koerner explicam que a judicialização da política requer que operadores da lei prefiram participar da policy-making a deixá-la ao critério de políticos e administradores e, em sua dinâmica, ela própria implicaria um papel político mais positivo da decisão judicial do que aquele envolvido em uma não decisão. ${ }^{268}$

No Brasil, o processo de redemocratização acabou por produzir enorme impacto no Poder Judiciário. Isso porque, de um lado, a demanda por justiça, em grande parte represada nos anos de autoritarismo, inundou o Poder Judiciário com o fim dos constrangimentos impostos pelo regime militar ao seu livre funcionamento. Por outro lado, a adoção de um Estado Democrático de Direito gerou a necessidade de juízes e árbitros legítimos virem a decidir sobre conflitos entre sociedade e governo e entre os Poderes do próprio Estado. Esse papel, segundo os autores, foi atribuído em grande medida ao Poder Judiciário. ${ }^{269}$

Rogério Bastos Arantes entende que, comparado às democracias contemporâneas, o Brasil passa praticamente pelas mesmas causas de judicialização da política de outros países:

First, political democracy was established in the 1980s followed by the approval of a new Constitution in 1988 that set out an extensive charter of

\footnotetext{
grandes ações de classe) também afetam as vidas de muitas pessoas. E ainda mais importante, como não existe uma resposta simples e direta para a questão "o que é político?" - para muitos teóricos sociais, a resposta a esta questão seria tudo é político" - também não pode existir uma definição simples e direta de judicialização da política. (...) De maneira semelhante, o que pode ser considerado um assunto político controverso em determinado governo (digamos, o direitos a realização um aborto nos Estados Unidos) pode não ser considerado um assunto controverso por outro governo. Isto dito, parece existir uma diferença qualitativa entre a evidência política de (por exemplo) uma decisão judicial refinando os limites do direitos a audiências justas ou à revisão da validade de quotas federais para exportação de agricultura e uma decisão emblemática determinando a legitimidade de um regime político ou a identidade coletiva de uma nação. De fato, poucas decisões podem ser consideradas mais "políticas" do que a definição autoritária da razão de ser de uma política. Esta elusiva, porém intuitiva, distinção é o que diferencia a judicialização de macropolíticas dos dois primeiros níveis de judicialização." (HIRSCHL, Ran. The New Constitutionalism and the Judicialization of Pure Politics Worldwide. Fordham Law Review, v. 75, n. 2, 2006, p. 718-720. Disponível em: http://ssrn.com/abstract=951610. Acesso em: 04 dez. 2013.)

${ }^{267}$ VERBICARO, Loiane Prado. Um estudo sobre as condições facilitadoras da judicialização da política no Brasil. Revista Direito GV, São Paulo, n. 4, Jul/dez. 2008, p. 391. Disponível em: http://www.scielo.br/pdf/rdgv/v4n2/a03v4n2.pdf. Acesso em: 04 dez. 2013.

268 MACIEL, Débora Alves; KOERNER, Andrei. Sentidos da judicialização da política: duas análises. Lua Nova: Revista de Cultura e Política. São Paulo, v. 57, 2002, p. 114.

${ }^{269}$ ARANTES, Rogério Bastos. Constitucionalism, the expansion of Justice and the judicialization of politics in Brazil In: SIEDER, Rachel; SCHJOLDEN; ANGELL, Alan. The judicialization of politics in Latin America. Nova York: Palgrave Macmillan, 2006, p. 83.
} 
rights. Second, an increasingly greater number of interest groups within society are demanding judicial solutions to collective conflicts. Third, the political system is characterized by fragile and even minority coalitions supporting the government of the day, while the opposition uses the judiciary to fight government policies. Lastly, the constitutional model delegates to the judiciary and to the Ministério Público (Public Ministry) the task of protecting both individual rights and interests, as well as collective and social rights. ${ }^{270}$

Com efeito, ao transpor para a realidade brasileira a sistemática de estudo de Nate e Vallinder, Loiane Prado Verbicaro esclarece que grande parte das condições facilitadoras da judicialização da política pode ser identificada, especialmente, a partir da redemocratização e reconstitucionalização do Brasil, após sucessivos períodos de autoritarismo. Dentre os fatos que facilitaram o surgimento e a consolidação desse processo de intervenção do Poder Judiciário em assunto políticos, destacam-se os seguintes: a promulgação da Constituição de 1988; a universalização do acesso à justiça; a estrutura tripartite da organização dos poderes do Estado; a existência de uma Constituição com textura aberta, normas programáticas e cláusulas indeterminadas; a crise do paradigma formalista de interpretação inspirado nas premissas do positivismo jurídico; a ampliação do espaço reservado ao STF; a permissão por parte da Constituição de 1988 para que o Poder Executivo edite medidas provisórias; a ampliação do rol de legitimados ativos a propor a ação direta de inconstitucionalidade; a veloz modificação da base econômica do Brasil; a existência de novas forças sociais representadas por importantes movimentos, organizações e grupos sociais; o agravamento da crise econômica nas últimas décadas do século XX, a ineficácia da política macroeconômica do país e a consequente explosão da crise social; a hipertrofia legislativa; e a desproporcionalidade entre a representação política e a crescente ineficácia do sistema político-decisório. $^{271}$

\footnotetext{
${ }^{270}$ ARANTES, Rogério Bastos. Constitucionalism, the expansion of Justice and the judicialization of politics in Brazil In: SIEDER, Rachel; SCHJOLDEN; ANGELL, Alan. The judicialization of politics in Latin America. Nova York: Palgrave Macmillan, 2006, p. 231. Em tradução livre: "Em primeiro lugar, a democracia política foi estabelecida nos anos 1980, seguida pela aprovação da nova Constituição em 1988, a qual previu um extenso catálogo de direito. Em segundo lugar, um número cada vez maior de grupos de interesse dentro da sociedade está demandando soluções judiciais para conflitos coletivos. Em terceiro lugar, o sistema político é caracterizado por frágeis, e até mesmo minoritárias, coalizões que dão suporte ao governo no dia-a-dia, enquanto a oposição usa o judiciário para combater as políticas governamentais. Finalmente, o modelo constitucional delega ao Judiciário e ao Ministério Público a tarefa de proteger tanto os direitos e interesses judiciais quanto os direitos sociais e coletivos."

${ }^{271}$ VERBICARO, Loiane Prado. Um estudo sobre as condições facilitadoras da judicialização da política no Brasil. Revista Direito GV, São Paulo, n. 4, jul/dez. 2008, p. 390. Disponível em: http://www.scielo.br/pdf/rdgv/v4n2/a03v4n2.pdf. Acesso em: 04 dez. 2013.
} 
Resumidamente, Luís Roberto Barroso afirma, em primeiro lugar, que judicialização da política significa que questões relevantes do ponto de vista político, social ou moral estão sendo decididas pelo Judiciário - "Trata-se, como intuitivo, de uma transferência de poder das instâncias tradicionais, que são o Executivo e o Legislativo, para juízes e tribunais.”. Em segundo lugar, aponta três causas, que considera mais relevantes, para esse fenômeno: A primeira é o reconhecimento de que um Judiciário forte e independente é imprescindível para a proteção dos direitos fundamentais. A segunda envolve uma certa desilusão com a política majoritária. Por fim, a terceira refere-se ao fato de que, muitas vezes, atores políticos, para evitar seu desgaste, preferem que o Judiciário decida questões controvertidas, como o aborto e direitos dos homossexuais. ${ }^{272}$

No Brasil, o fenômeno é ainda mais forte tendo em vista que a Constituição trata de uma enorme quantidade de temas, o que implica na transferência deles do âmbito da política para o campo do direito, permitindo, assim, a sua judicialização. A esse contexto, como já se disse, soma-se o expandido sistema de controle de constitucionalidade e a abertura das normas constitucionais, principalmente daquelas instituidoras de direitos fundamentais, que demandam densificação e concretização pelo Poder Judiciário.

Barroso entende, ainda, que o fenômeno da judicialização da política não é gerado espontaneamente. Ao contrário, tem origem, remotamente, na recusa, na leniência ou na oferta insatisfatória de prestações primárias que deveriam ser disponibilizadas pelo Poder Público à população. "Essa postura ineficiente passa a atrair as demandas reprimidas e as insatisfações gerais, as quais, restando sem atendimento e sem canal de expressão adequado, acabam se voltando para a instância que se apresenta quando as demais falham: o Judiciário.". 273

Mais do que isso, em estudo sobre o Supremo Tribunal Federal, José Ribas Vieira, Margarida Maria Lacombe Camargo e Alexandre Garrido Silva afirmam que há um consenso no sentido de que a assunção de novos papéis pelo Judiciário, incluindo as decisões sobre questões políticas, morais, religiosas, centrais, vem sendo aceita, não apenas pela sociedade, mas também pelos próprios atores políticos, em determinados casos. Isso porque,

Em casos politicamente custosos, os Poderes Legislativo e Executivo podem, de um modo estratégico, por meio de uma inércia deliberada, abrir um

\footnotetext{
${ }^{272}$ BARROSO, Luís Roberto. O novo direito constitucional brasileiro: contribuições para a construção teórica e prática da jurisdição constitucional no Brasil. Belo Horizonte: Fórum, 2013, p. 39.

${ }^{273}$ BARROSO, Luís Roberto. O novo direito constitucional brasileiro: contribuições para a construção teórica e prática da jurisdição constitucional no Brasil. Belo Horizonte: Fórum, 2013, p. 39-40.
} 
espaço para a atuação ativista dos tribunais. Temas profundamente controvertidos, sem perspectiva de consenso na sociedade, tais como a abertura dos arquivos da ditadura militar, uniões homoafetivas, aborto, entre outros, têm os seus custos políticos estrategicamente repassados para os tribunais, cujos integrantes não precisam passar pelo crivo do voto popular após suas decisões. ${ }^{274}$

No mesmo sentido, em interessante levantamento realizado por Luiz Werneck Vianna, Marcelo Baumann Burgos e Paula Martins Salles, constatou-se, inclusive, que, em grande parte, a internalização de questões políticas pelo Poder Judiciário foi incentivada pelos próprios atores políticos, "diante da perda de eficácia e de abrangência dos mecanismos próprios ao welfare, e igualmente conscientes da distância, nas democracias contemporâneas, entre representantes e representados". 275

Nessa medida, os atores políticos passam a estimular, por meio da expansão da legislação, os canais da representação funcional, intencionalmente aproximando a população do Poder Judiciário, por meio da regulamentação dos Juizados Especiais e da legislação relativa aos direitos do idoso, da criança e do adolescente, dos consumidores, entre outros. E, com a facilitação proposital do acesso à justiça pela população, o juiz, por provocação de agências da sociedade civil, alça lugar estratégico na tomadas de decisões em matéria de políticas públicas.

Segundo a análise de Vianna, Burgos e Salles,

O juiz torna-se protagonista direto da questão social. Sem política, sem partidos ou uma vida social organizada, o cidadão volta-se para ele, mobilizando o arsenal de recursos criado pelo legislador a fim de lhe proporcionar vias alternativas para a defesa e eventuais conquistas de direitos. A nova arquitetura institucional adquire seu contorno mais forte com o exercício do controle da constitucionalidade das leis e do processo eleitoral por parte do judiciário, submetendo o poder soberano às leis que ele mesmo outorgou. ${ }^{276}$

\footnotetext{
${ }^{274}$ VIEIRA, José Ribas; CAMARGO, Margarida Maria Lacombe; SILVA, Alexandre Garrido da. O Supremo Tribunal Federal como arquiteto institucional: a judicialização da política e o ativismo judicial. In: Anais do I Fórum de Grupos de Pesquisa em Direito Constitucional e Teoria do Direito. Rio de Janeiro: Faculdade Nacional de Direito, 2009, p. 44.

275 VIANNA, Luiz Werneck; BURGOS, Marcelo Baumann; Salles, Paula Martins. Dezessete anos de judicialização da política. Tempo Soc., São Paulo, v. 19, n. 2, Nov. 2007. p. 41. Disponível em: http://www.scielo.br/pdf/ts/v19n2/a02v19n2.pdf. Acesso em: 04 dez. 2013.

276 VIANNA, Luiz Werneck; BURGOS, Marcelo Baumann; Salles, Paula Martins. Dezessete anos de judicialização da política. Tempo Soc., São Paulo, v. 19, n. 2, Nov. 2007, p. 41. Disponível em: http://www.scielo.br/pdf/ts/v19n2/a02v19n2.pdf. Acesso em: 04 dez. 2013.
} 
Para respaldar esse entendimento, os autores resgatam a lição do constitucionalista alemão Dieter Grimm, segundo a qual a importância inédita adquirida pelos juízes, na política e na sociedade, não pode ser explicada por um suposto ativismo no desempenho dos seus papeis institucionais. Ao contrário, a extensão do poder do Judiciário sobre domínios antes reservados a outras forças decorre de ele ter sido dotado das competências que lhe permitam solucionar conflitos políticos e sociais. E, essa decisão que emprestou autoridade ao Judiciário não foi tomada por ele próprio, mas pelos atores políticos. ${ }^{277}$

Como verificamos anteriormente, o Poder Judiciário, ainda que interpretando e aplicando normas de textura aberta ou princípios, na inércia dos Poderes Legislativo e Executivo, assim o faz de modo legítimo, pois tal atribuição lhe foi conferida pela própria Constituição de 1988, ao criar mecanismos processuais que viabilizam a atuação mais criativa do Supremo Tribunal Federal (e não meramente subsuntiva). Além disso, com suporte em análise mais detalhada dos Poderes Legislativo e Judiciário brasileiros, podemos confirmar a conclusão inicial de que a separação de Poderes molda-se às particulares circunstâncias do Estado Contemporâneo.

Assim, parece-nos acertada a conclusão de Vianna, Burgos e Salles, sobre a atuação do Poder Judiciário ser, em parte, incitada (mesmo que de modo tácito) pelos próprios Poderes Executivo e Legislativo, os quais optam por se abster da tomadas de decisões de alto custo político, tais como as relativas aos efeitos da união de entre pessoas do mesmo sexo, ao aborto de fetos anencefálicos entre outros.

Não obstante, o Supremo Tribunal Federal, tem sofrido severas críticas, assim como sofreu a Suprema Corte americana em meados do século XX, no sentido de que a Corte não seria órgão competente para tratar de questões políticas por não ser eleito pelo povo e, portanto, não possuir legitimidade democrática para manifestar-se sobre tais questões.

Isso porque, como ressalta Gisele Cittadino, se, por um lado, parece não restar dúvida sobre a importância da atuação do Poder Judiciário no que diz respeito à garantia da concretização dos direitos da cidadania, é fundamental que o seu atual protagonismo seja compatível com as bases do constitucionalismo democrático. ${ }^{278}$

\footnotetext{
277 VIANNA, Luiz Werneck; BURGOS, Marcelo Baumann; Salles, Paula Martins. Dezessete anos de judicialização da política. Tempo Soc., São Paulo, v. 19, n. 2, Nov. 2007, p. 41. Disponível em: http://www.scielo.br/pdf/ts/v19n2/a02v19n2.pdf. Acesso em: 04 dez. 2013.

${ }^{278}$ CITTADINO, Gisele. Judicialização da política, constitucionalismo democrático e separação de poderes. In: VIANNA, Luiz Werneck (Org.). A democracia e os três Poderes no Brasil. Belo Horizonte: UFMG, Rio de Janeiro: IUPERJ/FAPERJ, 2003, p. 19.
} 
Nessa medida, as críticas são muito mais incisivas no que diz respeito a um "exagero" na atuação do Poder Judiciário ao tratar de questões políticas, do que pode decorrer, por exemplo, a usurpação da função legislativa (função tipicamente política, que cabe precipuamente ao Poder Legislativo), do que à ideia em si de aproximação entre direito e política.

Ousamos dizer, portanto, que as críticas acerca da expansão da intervenção judicial referem-se menos à judicialização da política do que ao fenômeno denominado ativismo judicial. Ora, ensina Barroso, a judicialização é um fato, uma circunstância do desenho institucional brasileiro. Já o ativismo é uma atitude, uma escolha de um modo específico e proativo de interpretar a Constituição, expandindo seu sentido e alcance:

A judicialização e o ativismo judicial são primos. Vêm, portanto, da mesma família, frequentam os mesmos lugares, mas não têm as mesmas origens. Não são gerados, a rigor, pelas mesmas causas imediatas. A judicialização, no contexto brasileiro, é um fato, uma circunstância que decorre do modelo constitucional que se adotou, e não um exercício deliberado de vontade política. (...) Se uma norma constitucional permite que dela se deduza uma pretensão, subjetiva ou objetiva, ao juiz cabe dela conhecer, decidindo a matéria. Já o ativismo judicial é uma atitude, uma escolha de um modo específico e proativo de interpretar a Constituição, expandindo o seu sentido e alcance. Normalmente ele se instala em situações de retração do Poder Legislativo, de um certo deslocamento entre a classe política e a sociedade civil, impedindo que as demandas sociais sejam atendidas de maneira efetiva. $^{279}$

O termo ativismo judicial foi utilizado pela primeira vez nos Estado Unidos, em 1947, pelo jornalista Artgur Schlesinger Jr., em artigo sobre a atuação da Suprema Corte americana, publicado na revista Fortune. ${ }^{280} \mathrm{O}$ artigo tratava sobre a atuação dos magistrados daquela Corte, classificando parte deles como ativistas e outra parte como praticantes de um self restraint (autocontenção), ou seja, uma postura mais contida.

Luís Roberto Barroso comenta que essa expressão foi utilizada para rotular a Suprema Corte americana no período em que foi presidida por Earl Warren, entre 1954 e 1969, quando a jurisprudência da Corte sofreu grandes alterações, tornando-se sensivelmente mais progressista em matéria de direitos fundamentais, sem que houvesse a participação do

\footnotetext{
${ }^{279}$ BARROSO, Luís Roberto. Judicialização, ativismo judicial e legitimidade democrática. Revista de Direito do Estado, Rio de Janeiro, n. 13, jan/mar. 2009, p. 77.

${ }^{280}$ LEAL, Saul Tourinho. Ativismo ou altivez? O outro lado do Supremo Tribunal Federal. Belo Horizonte: Fórum, 2010, p. 24.
} 
Congresso Nacional ou do Presidente da República em tais transformações. ${ }^{281}$ A partir de então, em razão de uma intensa reação conservadora, a expressão ativismo judicial ganhou contornos negativos, depreciativos, sendo equiparada ao exercício impróprio do poder judicial, por meio da usurpação de funções. ${ }^{282}$

Seguindo a corrente que atribui ao ativismo judicial conotação negativa, temos, no Brasil, Elival da Silva Ramos, que entende que esse fenômeno revela o exercício da função jurisdicional para além dos limites impostos pelo próprio ordenamento, segundo o qual incumbe, institucionalmente, ao Poder Judiciário a resolução de litígios de feições subjetivas (conflitos de interesse) e de controvérsias jurídicas de natureza objetiva (conflitos normativos). ${ }^{283}$

Calcado em parâmetros dogmáticos, o autor afirma que as práticas ativistas implicam em uma "desnaturação da atividade típica do Poder Judiciário, em detrimento dos demais Poderes", em especial o Poder Legislativo, "o qual pode ter o produto da legiferação irregularmente invalidado por decisão ativista (em sede de controle de constitucionalidade), quanto o seu espaço de conformação normativa invadido por decisões excessivamente criativas.". ${ }^{284}$

Por sua vez, segundo Carl Sustein, em uma primeira acepção, o ativismo judicial será medido pela frequência com que um determinado magistrado ou tribunal invalida as ações (normas ou atos normativos) de outros Poderes, especialmente do Legislativo. Ou seja, com que frequência os tribunais "retiram a decisão das mãos dos eleitores". Além disso, Sustein que deve ser considerado também ativista o magistrado ou tribunal que procura suprir omissões (reais ou aparentes) dos demais Poderes com suas decisões, como, por exemplo, no tocando à definição ou concretização de políticas públicas ou regulamentação das regras do jogo democrático. ${ }^{285}$

\footnotetext{
${ }^{281}$ BARROSO, Luís Roberto. O controle de constitucionalidade no Direito Brasileiro. 5. ed. São Paulo: Saraiva, 2011, p. 364.

${ }^{282}$ No entanto, o próprio Barroso, no entanto, é contrário a tal entendimento. Para ele: "A ideia de ativismo judicial está associada a uma participação mais ampla e intensa do Judiciário na concretização dos valores e fins constitucionais, com maior interferência no espaço de atuação dos outros dois Poderes. (...) o ativismo é uma atitude, a escolha de um modo específico e proativo de interpretar a Constituição, expandindo o seu sentido e alcance. (...) o ativismo legitimamente exercido procura extrair o máximo das potencialidades do texto constitucional, inclusive e especialmente construindo regras especificas de conduta a partir de enunciados vagos.". BARROSO, Luís Roberto. O controle de constitucionalidade no Direito Brasileiro. 5. ed. São Paulo: Saraiva, 2011, p. 365-6.

${ }^{283}$ RAMOS, Elival da Silva. Ativismo judicial: parâmetros dogmáticos. São Paulo: Saraiva, 2010, p. 120.

${ }^{284}$ RAMOS, Elival da Silva. Ativismo judicial: parâmetros dogmáticos. São Paulo: Saraiva, 2010, p. 129.

${ }^{285}$ SUSTEIN, Carl. Radicals in robes: why extreme right-wing Courts are wrong for America. New York: Basic Books, 2005, p. 41-44.
} 
Apesar das dificuldades teóricas e práticas para definir o ativismo judicial, coube a Marshall, em seu artigo Conservatives and the seven sins os judicial activism, elaborar uma classificação de tipos-ideais de ativismo judicial, por meio de conceitos que possibilitam uma melhor compreensão do fenômeno. Seriam eles: 1) o ativismo contramajoritário: marcado pela relutância em relação às decisões dos Poderes diretamente eleitos; 2) o ativismo não originalista: caracterizado pelo não reconhecimento de qualquer originalismo na interpretação judicial, sendo as concepções mais estritas do texto legal e as considerações sobre a intenção do legislador inteiramente abandonadas; 3 ) o ativismo de precedentes: consistente na rejeição de precedentes anteriormente estabelecidos; 4) o ativismo formal (ou jurisdicional): marcado pela resistência das Cortes em aceitar os limites legalmente estabelecidos para sua atuação; 5) o ativismo material (ou criativo): resultante da criação de novos direitos e teorias na doutrina constitucional; 6) o ativismo remediador: marcado pelo uso do poder judicial para impor atuações positivas a outros Poderes governamentais ou controlá-las como etapa de uma correção imposta judicialmente; e 7) o ativismo partisan: consistente no uso do poder judicial para atingir objetivos específicos de um determinado partido ou segmento social. ${ }^{286}$

Sem pretender nos posicionarmos favorável ou contrariamente aos fenômenos descritos acima, limitamo-nos a constatar que, dentre os diversos julgados do Supremo Tribunal Federal, no exercício de sua função política, vários deles têm sido vinculados à judicialização da política e outros tantos ao ativismo judicial.

Com efeito, não é novidade que o Supremo Tribunal Federal, no exercício de suas competências, tem cada vez mais decidido sobre situações que o inserem num contexto de protagonismo político e social. São poucos os dias que se passam sem que a grande mídia veicule informações sobre o julgamento pelo Tribunal de questões políticas que interessam, de maneira geral, à população.

Diante do inafastável dever de julgar e da primorosa necessidade de se efetivar a Constituição, o Supremo apreciou casos que exigiram dele uma postura proativa na atividade interpretativa. Nessa medida, Barroso afirma que os precedentes de postura ativista da Corte podem ser identificados por diferentes linhas de decisão: ${ }^{287}$ (i) a aplicação direta da Constituição a situações não expressamente contempladas em seu texto e independentemente de manifestação do legislador ordinário, como foi o caso da imposição de fidelidade

\footnotetext{
${ }^{286}$ MARSHALL, William P. Conservatives and the seven sins of judicial activism. University of Colorado Law Review, v. 73, Sep. 2002. Disponível em: http://ssrn.com/abstract=330266. Acesso em: 11 jan. 2014.

${ }^{287}$ BARROSO, Luís Roberto. O novo direito constitucional brasileiro: contribuições para a construção teórica e prática da jurisdição constitucional no Brasil. Belo Horizonte: Fórum, 2013, p. 246.
} 
partidária, em que se decidiu que o mandato representativo pertence ao partido político e não ao candidato eleito (Mandados de segurança n. 22.602, 22.603 e 22.604); (ii) a declaração de inconstitucionalidade de atos normativos emanados do legislador, com base em critérios menos rígidos que os de patente e ostensiva violação à Constituição, como foi o caso da verticalização das coligações partidárias (Ação direta de inconstitucionalidade n. 3.685-8) e do reconhecimento da união estável homoafetiva, (Ação de descumprimento de preceito fundamental n. 132, convertida na Ação direta de inconstitucionalidade n. 4.277); e (iii) a imposição de condutas ou de abstenções ao Poder Público, tanto de caso de inércia do legislador - caso da greve dos servidores públicos (Mandado de injunção n. 670)- como no de políticas públicas insuficientes, tendo como um exemplo o caso da demarcação das terras indígenas (Ação popular n. 3.388).

Segundo o entendimento de Barroso, todas essas hipóteses acima apresentadas distanciam juízes e tribunais de sua função típica de aplicação do direito vigente e os aproximam de uma função que mais se assemelha à de criação do próprio direito.

Como se verifica, o Supremo Tribunal Federal foi chamado a um verdadeiro papel de mediação de interesses e arbitramento de disputas entre atores políticos, sobretudo entre governo e oposição. Os exemplos disso vão muito além daqueles mencionados acima, o que demonstra que o Tribunal não parece ter ficado omisso a esse chamamento. Ao contrário, assumiu com crescente clareza o seu papel político e passou a exercer sua competência de revisão judicial com cada vez mais desenvoltura, quer no controle difuso, quer no controle concentrado. $^{288}$

Relativamente ao controle difuso, é possível referir a pesquisa realizada por Marcus Faro de Castro, em que foram analisadas 1.240 das 7.955 ementas de acórdãos julgados pelo Supremo Tribunal Federal e publicados no primeiro semestre de 1994. Os resultados demonstraram, em primeiro lugar, que mais da metade dos processos analisados $(58,1 \%)$ veiculava questões de política fiscal ou tributária. Em segundo lugar, mostrou que, em 75,5\% dos casos, o Tribunal produziu decisões totalmente contrárias aos interesses do Estado veiculados nos respectivos processos. Dentre as decisões contrárias ao interesse estatal, mais da metade $(50,88 \%)$ dizia respeito, justamente, a temas de política fiscal e tributária. ${ }^{289}$

\footnotetext{
${ }^{288}$ VERÍSSIMO, Marcos Paulo. A Constituição de 1988, vinte anos depois: Suprema Corte e ativismo judicial “à brasileira”. Revista Direito GV, v. 4, ano 2, p. 407-440, jul/dez. 2008, p. 412.

${ }^{289}$ CASTRO, Marcus Faro de. O Supremo Tribunal Federal e a judicialização da política. Revista Brasileira de Ciências Sociais. São Paulo, v. 12, n. 34, p. 147-156, 1997.
} 
Ainda como exemplo de ativismo judicial no âmbito do controle difuso, Marcos Paulo Veríssimo cita o da derrota sofrida pelo governo em relação ao tema da correção monetária incidente sobre as contas de FGTS durante o período de 1989-1990 (Plano Verão e Plano Collor). ${ }^{290}$

Por sua vez, no campo do controle concentrado, o autor refere-se a importantes temas políticos levados ao Supremo Tribunal Federal, como aquele ligado à Lei de Biossegurança (Ação direta de inconstitucionalidade n. 3.510), à reforma partidária (Ações diretas de inconstitucionalidade n. 1.351 e n. 1.354), tendo nesta havido declaração de inconstitucionalidade, como ocorreu também no caso da verticalização das candidaturas para a eleição de 2006 (Ação direta de inconstitucionalidade n. 3.685-8). Sobretudo, indica como exemplo a batalha judicial travada em torno da contribuição previdenciária dos inativos. Isso porque, apesar de o governo ter saído vencedor por apenas três votos de vantagem, teve de arcar, mesmo assim, com uma vitória parcial, já que o voto vencedor do Ministro Cezar Peluso, embora tenha mantido a constitucionalidade da política, aumentou o limite de isenção respectivo, em decisão que serve como demonstrativo do exercício de competências legislativas pelo órgão judiciário, para além do mero poder de veto. ${ }^{291}$

Não é nosso objetivo neste trabalho analisar se a postura do Supremo Tribunal Federal pode, de fato, ser considerado "ativista", basta-nos a constatação de que, pelos motivos já apresentados relativos à expansão da jurisdição constitucional (consolidação do controle de constitucionalidade e "nova" interpretação constitucional) e à descrença nos Poderes Legislativo e Executivo, a Corte vem sendo mais procurada para analisar questões políticas e, atendendo a essa expectativa, vem colocando em pauta e julgando diversos casos em que tais questões são postas.

Se, por um lado, foi a própria Constituição Federal de 1988 que conferiu competências que permitiram ao Supremo Tribunal Federal uma maior atuação política, é certo que a Corte não escapa às críticas por um suposto exagero nessa atuação. Dentre elas, as principais, referem-se a uma eventual violação à legitimidade democrática da Corte e à separação de Poderes.

Passaremos a discorrer sobre essas críticas, visando a direcionar a discussão para o desfecho desse trabalho, que se refere ao impacto dessa nova atuação do Supremo Tribunal

${ }^{290}$ VERÍSSIMO, Marcos Paulo. A Constituição de 1988, vinte anos depois: Suprema Corte e ativismo judicial "à brasileira". Revista Direito GV, v. 4, ano 2, p. 407-440, jul/dez. 2008, p. 412.

${ }^{291}$ VERÍSSIMO, Marcos Paulo. A Constituição de 1988, vinte anos depois: Suprema Corte e ativismo judicial “à brasileira”. Revista Direito GV, v. 4, ano 2, p. 407-440, jul/dez. 2008, p. 413. 
Federal sobre o equilíbrio de Poderes, especialmente sobre eventuais consequências para o diálogo entre o Poder Judiciário e o Poder Legislativo.

3.2.1. Críticas à expansão da interferência judicial em questões políticas

A partir da promulgação da Constituição de 1988, com o fortalecimento progressivo do Poder Judiciário, demandas antes veiculadas apenas por via política, por exemplo, por meio das eleições e da atividade do Poder Legislativo, passaram a ser pleiteadas no âmbito judicial. Segundo Luiza Cristina Fonseca Frischeisen, essa atuação não teria o intuito de substituir o Executivo e o Legislativo pelo Judiciário ou pelo Ministério Público, mas simplesmente de assegurar o cumprimento e a adequada interpretação da Constituição Federal e das leis, em sintonia com as diversas demandas da sociedade. ${ }^{292}$

No entanto, é certo que a atuação mais incisiva do Supremo Tribunal Federal no que se refere a questões políticas (ou seja, de interesse geral da população) suscita uma série de críticas, principalmente relativas ao impacto sobre o equilíbrio entre os Poderes Legislativo e Judiciário.

Com efeito, as maiores discussões doutrinárias e jurisprudenciais são relacionadas ao que se pode denominar "crítica política", referente à questão da legitimidade democrática da Corte para invalidar ou interferir em atos do Legislativo ou do Executivo, decidindo em última instância sobre questões políticas, e à separação dos Poderes, princípio que restaria violado em razão de uma suposta usurpação da função legislativa pelo Supremo.

Por ser tema de maior expressão e por se tratar de questão central deste trabalho, optamos por discutir essa crítica política, bem como sua pertinência, por último, passando, primeiramente, por outros questionamentos suscitados pela atuação do Supremo Tribunal Federal relativamente a questões políticas.

Barroso faz referência a uma crítica de cunho ideológico, segundo a qual o Judiciário seria uma instância tradicionalmente conservadora das distribuições de poder e de riqueza na

${ }^{292}$ FRISCHEISEN, Luiza Cristina Fonseca. Construção da igualdade e o sistema de justiça no Brasil: alguns caminhos e possibilidades. 2004. 139p. Tese (Doutorado em Filosofia e Teoria Geral do Direito) - Faculdade de Direito, Universidade de São Paulo, São Paulo, 2004, p. 78-79. 
sociedade. "Nessa perspectiva, a judicialização da política funcionaria como uma reação das elites tradicionais contra a democratização, um antídoto contra a participação popular e a política majoritária.". 293

Também sob esse ponto de vista, após analisar as experiências do Canadá, Nova Zelândia, Israel e África do Sul, Ran Hirschl conclui que o aumento do poder judicial por via da constitucionalização é, no geral,

(...) um pacto estratégico entre três partes: as elites políticas hegemônicas que pretendem proteger suas preferências políticas contra as vicissitudes da política democrática; as elites econômicas que comungam da crença no livre mercado e da antipatia com relação ao governo; e cortes supremas que buscam fortalecer seu poder simbólico e sua posição institucional. ${ }^{294}$

Igualmente, nos Estados Unidos, uma corrente de pensamento referida como "constitucionalismo popular" também critica a ideia de supremacia judicial. Mark Tushnet, por exemplo, sustenta que "os liberais (progressistas) de hoje parecem ter um profundo medo do processo eleitoral. Cultivam um entusiasmo no controle judicial que não se justifica, diante das experiências recentes. Tudo porque têm medo do que o povo pode fazer.". ${ }^{295}$

Ainda, é comum a crítica à capacidade institucional do Poder Judiciário. Segundo Barroso, a primazia de que goza o Judiciário quanto à palavra final na interpretação constitucional não significa que toda e qualquer matéria deva ser decidida por um tribunal, sob pena de o Judiciário se tornar uma indesejável instância hegemônica. ${ }^{296}$ Para evitar essa situação, a doutrina constitucional vem explorando duas ideias para limitar a ingerência judicial: a de capacidade institucional e a de efeitos sistêmicos.

A ideia de capacidade institucional envolve a determinação de qual Poder está mais bem aparelhado a produzir a melhor decisão em determinada matéria. Nessa medida, temas envolvendo aspectos técnicos ou científicos de grande complexidade podem não ter no juiz de direito o árbitro mais qualificado, por lhe faltar conhecimento técnico específico. Além disso, decisões judiciais relativas a referidos temas podem provocar efeitos sistêmicos imprevisíveis e indesejáveis, uma vez que, embora o juiz esteja preparado para realizar a justiça no caso

\footnotetext{
${ }^{293}$ BARROSO, Luís Roberto. O novo direito constitucional brasileiro: contribuições para a construção teórica e prática da jurisdição constitucional no Brasil. Belo Horizonte: Fórum, 2013, p. 248.

${ }^{294}$ HIRSCHL, Ran. Towards juristocracy: the origins and consequences of the new constitucionalism. Cambridge and London: Harvard University Press, 2004, p. 214.

${ }^{295}$ TUSHNET, Mark. Taking the constitution away from the courts. Princeton: Princeton University Press, 1999, p. 177.

${ }^{296}$ BARROSO, Luís Roberto. O novo direito constitucional brasileiro: contribuições para a construção teórica e prática da jurisdição constitucional no Brasil. Belo Horizonte: Fórum, 2013, p. 249.
} 
concreto, a microjustiça, ele pode falhar na avaliação do impacto de suas decisões sobre um segmento econômico ou sobre a prestação de um serviço público.

Por fim, pode-se falar em crítica quanto à limitação do debate judicial. Isso porque o direito tem categorias, discurso e métodos de argumentação próprios. O domínio desses instrumentos exige conhecimento técnico e treinamento específico, inacessíveis à generalidade das pessoas. Assim, a primeira consequência indesejável da judicialização da política é a elitização do debate e a exclusão daqueles que não dominam a linguagem jurídica ou que não tem acesso à discussão jurídica. Por isso dizer-se que o Poder Legislativo é o local mais adequado para a discussão de questões políticas de interesse dos cidadãos, por promover debates abertos e abrangentes.

Barroso atenta para que institutos como audiências públicas, amicus curiae e o direito de proposição de ações diretas por entidades da sociedade civil atenuam, mas não eliminam esse problema. E faz o alerta para o "perigo de se produzir uma apatia das forças sociais, que passariam a ficar à espera de juízes providenciais”. O jurista destaca, ainda, que a transferência do debate público para o Judiciário traz uma dose excessiva de politização dos tribunais, ensejando a tomada de decisões movidas pela paixão em um ambiente que deve se pautar pela razão, mostrando a consequências dessa politização:

No movimento seguinte, processos passam a tramitar nas manchetes de jornais - e não na imprensa oficial - e juízes trocam a racionalidade plácida da argumentação jurídica por embates próprios da discussão parlamentar, movida por visões políticas contrapostas e concorrentes. ${ }^{297}$

Embora as críticas até aqui expostas já evidenciem a conflituosidade entre Legislativo e Judiciário no exercício da função política, passamos, agora, a tratar da relevante questão acerca da legitimidade democrática do Supremo Tribunal Federal e de sua interferência na separação de Poderes, que são mais candentes quando relacionados ao ativismo judicial.

Boaventura de Souza Santos esclarece que a questão da legitimidade surge apenas nos regimes democráticos e diz respeito à formação da vontade da maioria por meio da representação política advinda das eleições. Assim, tendo em vista os países em que os membros do Poder Judiciário não são eleitos, questiona-se o conteúdo democrático do

\footnotetext{
297 O novo direito constitucional brasileiro: contribuições para a construção teórica e prática da jurisdição constitucional no Brasil. Belo Horizonte: Fórum, 2013, p. 250.
} 
intervencionismo judicial sempre que este interfere nas funções do Poder Legislativo e do Poder Executivo. $^{298}$

Com efeito, juízes e membros dos tribunais não são agentes públicos eleitos, não foram investidos em seus cargos por vontade popular, logo, não são representantes dessa vontade. Por causa disso, a possibilidade de as instâncias judiciais sobreporem suas decisões às dos agentes políticos eleitos enseja a denominada "dificuldade contramajoritária", que pode ser explicada segundo as palavras de Alexander Bickel:

A questão mais profunda é que o controle de constitucionalidade (judicial review) é uma força contramajoritária em nosso sistema. (...) [Q]uando a Suprema Corte declara inconstitucional um ato legislativo ou um ato de um membro do Executivo, ele se opõe à vontade dos representantes do povo, o povo que está aqui e agora; ela exerce um controle, não em nome da maioria dominante, mas contra ela. (...) O controle de constitucionalidade, no entanto, é o poder de aplicar e interpretar a Constituição, em matérias de grande relevância, contra a vontade da maioria legislativa, que, por sua vez, é impotente para se opor à decisão judicial. ${ }^{299}$

Um dos principais representantes da corrente de críticos da legitimidade democrática dos Tribunais para o exercício do controle de atos praticados pelo Legislativo é Jeremy Waldron, cuja tese central é a de que nas sociedades democráticas nas quais o Legislativo não seja "disfuncional", as divergências acerca dos direitos devem ser resolvidas no âmbito do processo legislativo e não do processo judicial. ${ }^{300}$

Uma das principais preocupações desse autor é combater a ideia, bastante difundida, de que o procedimento legislativo pode dar origem à tirania da maioria e que essa maioria, constantemente, viola ou constrange o exercício de direitos individuais ou das minorias - e daí se originaria a necessidade de determinados limites ao procedimento democrático majoritário. Todavia, o fato de que esses direitos podem ser violados pela maioria não decorre, necessariamente, que a única maneira de evitar que isso aconteça seja controlando a vontade da maioria por meio do judicial review. ${ }^{301}$

\footnotetext{
${ }^{298}$ SANTOS, Boaventura de Souza. Os tribunais das sociedades contemporâneas: o caso português. 2. ed. Porto: Afrontamento, 1996, p. 20.

${ }^{299}$ BICKEL, Alexander M. The least dangerous branch: the Supreme Court at the bar of politics. New Haven: Yale University Press, 1986, p. 16-23.

300 Jeremy Waldron esclarece que sua análise refere-se apenas à revisão judicial de atos oriundos do Legislativo e não do Executivo. Cf. WALDRON, Jeremy. The core of the case against judicial review. Yale Law Journal, v. 115, 2006. Disponível em: http://www.yalelawjournal.org/pdf/115-6/Waldron.pdf. Acesso em: 12 jan. 2014.

${ }^{301}$ WALDRON, Jeremy. Law and disagreement. Oxford: Clarendon Press, 1999, p. 11.
} 
No ensaio The core of the case against judicial review, Waldron enuncia que a crítica ao judicial review pode ser levada a efeito mediante dois argumentos centrais: (i) não existe nenhuma razão para supor que os direitos estariam mais bem protegidos pelo exercício do judicial review do que por legislaturas democráticas; e (ii) não obstante os resultados que o judicial review possa gerar, sob o ponto de vista da democracia ele é ilegítimo. ${ }^{302}$

A análise que o autor faz desse problema não está centrada em decisões particulares obtidas dentro de um sistema político e também não se prende ao contexto histórico que dá origem ao instituto, sua intenção foi formular uma crítica geral ao instituto. ${ }^{303}$

Ao esclarecer a ideia por trás da crítica à legitimidade democrática dos tribunais, Cláudio Pereira de Souza Neto aventa que a democracia incrementa a racionalidade das decisões públicas, de modo que a deliberação que deve preceder às decisões em um regime democrático tem as seguintes vantagens, que não podem ser encontradas no Judiciário: "torna disponíveis novas informações; permite que os interesses privados e as pretensões ilegítimas de poder sejam denunciados; obriga os governantes a se justificarem publicamente.". 304

À tese de Waldron opõe-se Ronald Dworkin. Os autores divergem não apenas com relação à legitimidade da revisão judicial, mas, antes disso, com relação ao próprio conceito de democracia - o primeiro aderindo a uma concepção procedimental da democracia e o segundo, como já referido neste trabalho anteriormente, a uma concepção substantiva. Essa contraposição é exemplarmente analisada por Conrado Hübner Mendes, ${ }^{305}$ como veremos no próximo tópico, ao verificar as possibilidades de uma nova dinâmica entre os Poderes Legislativo e Judiciário no pós-88.

Relacionada à crítica referente à legitimidade está a crítica a uma suposta violação da separação de Poderes. Isso porque, como explica Elival da Silva Ramos, o Estado Democrático de Direito está sedimentado sobre a garantia da divisão dos Poderes, tal qual posto no artigo $3^{\circ}$ da Constituição Federal de 1988, de modo que uma atuação mais incisiva do Poder Judiciário - ultrapassando seu limite de interpretação constitucional e passando, por

\footnotetext{
${ }^{302}$ WALDRON, Jeremy. The core of the case against judicial review. Yale Law Journal, v. 115, 2006, p. 1346. ${ }^{303}$ WALDRON, Jeremy. The core of the case against judicial review. Yale Law Journal, v. 115, 2006, p. 13461351.

${ }^{304}$ SOUZA NETO, Cláudio Pereira. A justiciabilidade dos direitos sociais: críticas e parâmetros. In: SARMENTO, Daniel. (Coord.) Direitos sociais: fundamentos, judicialização e direitos sociais em espécie. Rio de Janeiro: Lumen Iuris, 2008, p. 515-551, p. 523.

305 MENDES, Conrado Hübner. Direitos fundamentais, separação de poderes e deliberação. São Paulo: Saraiva, 2011. (Série direito desenvolvimento justiça: produção científica)
} 
exemplo, a expedir mandamentos gerais e abstratos, função exclusiva do Poder Legislativo ameaçaria a estabilidade do regime democrático, agindo em desacordo com ele. ${ }^{306}$

O liberalismo político sustenta que o poder do Estado não pode se concentrar em um único órgão de tomada de decisões, ao contrário, deve ser distribuído entre órgãos distintos, a fim de que o poder freie o poder, segundo a clássica lição de Montesquieu. Desse modo, no cenário sob análise, o Poder Judiciário estaria usurpando funções do Executivo e do Legislativo ao decidir questões políticas, cujo debate caberia, num primeiro momento, àqueles Poderes. Isso ocorre com o Poder Executivo quando o Judiciário cria ou ajusta políticas públicas. Mas ocorre com maior frequência com o Poder Legislativo, quando o Judiciário anula seus atos normativos ou densifica normas para aplicação ao caso concreto, sub-rogandose no dever do Legislativo.

Questiona-se, portanto, se o Poder Judiciário teria legitimidade para fazer tais escolhas políticas, diante da ausência de representatividade, chegando-se comumente à conclusão do caráter antidemocrático da atuação judicial criativa e da agressão à harmonia entre os Poderes. Nesse sentir, Ramos sintetiza a questão da seguinte forma:

(...) nos Estados Democráticos a subversão dos limites impostos à criatividade da jurisprudência, com o esmaecimento de sua função executória, implica a deterioração da função jurisdicional, cuja autonomia é inafastável sob a vigência de um Estado de Direito afetando-se inexoravelmente, as demais funções estatais, máxime a legiferante, o que, por seu turno, configura gravíssima agressão ao princípio da separação de Poderes. ${ }^{307}$

Não obstante a doutrina tradicional, mais apegada ao positivismo liberal, posicionar-se no sentido acima exposto, não é demais ressaltar que a democracia não pode ser encarada apenas sob o ponto de vista procedimental. Ora, a democracia também possui um viés substancial, que se funda na promoção dos direitos fundamentais.

Nessa medida, a legitimidade do Poder Judiciário para interpretar as normas constitucionais e concretizar os direitos nelas previstos não decorre mais da estrutura política do Estado, mas do fato de que cabe ao Judiciário proteger os direitos fundamentais por meio do controle de constitucionalidade. Luigi Ferrajoli diz que

Esta legitimación no tiene nada que ver con la de la democracia política, ligada a la representación. No se deriva de la voluntad de la mayoría, de la

\footnotetext{
${ }^{306}$ RAMOS, Elival da Silva. Ativismo judicial: parâmetros dogmáticos. São Paulo: Saraiva, 2010, p. 111-120.

${ }^{307}$ RAMOS, Elival da Silva. Ativismo judicial: parâmetros dogmáticos. São Paulo: Saraiva, 2010, p. 120.
} 
que asimismo la ley es expresión. Su fundamento es únicamente la intangibilidad de los derechos fundamentales. ${ }^{308}$

Evidentemente, nesse quadro, haverá um juiz com maior intervenção e os casos de ingerência do Poder Judiciário na esfera de competências do Poder Legislativo serão mais frequentes.

Para análise da legitimidade dos tribunais e interferência deles na separação dos Poderes, é interessante retomar a discussão acerca do papel do juiz nos sistemas de Commom Law, caso dos Estados Unidos, onde se originou o ativismo judicial, e no de Civil Law, caso brasileiro.

Os países que adotam o sistema de Common Law possuem como principal fonte normativa a jurisprudência, calcada nos precedentes, sendo exceção o direito posto legislativamente. Nos sistemas de Civil Law, ao contrário, são as leis as fontes normativas primárias, restando ao Judiciário a interpretação e complementação casuística das normas postas pelo Legislativo, na medida em que este lhe autorize tal exercício ou lhe dê margem para tanto. Nesse sentido, Ramos observa que:

Se o ativismo judicial, em uma noção preliminar, reporta-se a uma disfunção no exercício da função jurisdicional, em detrimento, notadamente, da função legislativa, a mencionada diferença de grau permite compreender porque nos ordenamentos filiados ao sistema de common law é muito mais difícil do que seria nos sistemas da família romano-germânica a caracterização do que seria uma atuação ativista da magistratura, a ser repelida em termos dogmáticos, em contraposição a uma atuação mais ousada, porém ainda dentro dos limites do permitido. ${ }^{309}$

Com efeito, enquanto, na família romano-germânica, a lei foi erigida como princípio fundamental para se chegar às soluções justas, devendo os juristas, nas soluções do caso concreto, estarem adstritos às orientações e às regulamentações por ela propostas, na Common Law, é o processo que visa atingir soluções justas, sendo que, por meio deles, os juízes atualizam o Direito, pautados na realidade concreta que lhes é apresentada.

Assim, é o juiz quem desenvolve o direito nos países de tradição de Common law (judge-made-law). É da essência desse sistema que o direito opere pelo Judiciário. Na célebre

\footnotetext{
${ }^{308}$ FERRAJOLI, Luigi. Derechos y garantias: la ley del más débil. 2. ed. Madrid: Trotta, 2001, p. 27. Em tradução livre da autora: "Esta legitimação não tem nada a ver com a da democracia política, ligada à representação. Não é derivada da vontade da maioria, da qual também a lei é uma expressão. Seu fundamento é unicamente a intangibilidade dos direitos fundamentais".

${ }^{309}$ RAMOS, Elival da Silva. Ativismo judicial: parâmetros dogmáticos. São Paulo: Saraiva, 2010, p. 107.
} 
frase do Juiz Wendell Holmes, da Suprema Corte americana: "a constituição dos Estados Unidos é o que a Suprema Corte diz que é".310

A expressão judge-made-law tem esta profunda raiz no Common Law, de modo que, nesse sistema, por regra, o juiz não é ativista. Ele, em verdade, cumpre o seu papel de improvisação continuada, a cada vez que é chamado a se pronunciar sobre um caso concreto.

Nessa medida, a questão do ativismo judicial, apresentada anteriormente, envolve os limites a que está adstrita a função hermenêutica do Poder Judiciário, considerada no âmbito maior de divisão de funções segundo a tripartição de Poderes. Em outras palavras, o estudo desse fenômeno e sua verificação na prática devem pressupor o estabelecimento do limite entre a extensão da possibilidade de criação por parte dos magistrados no momento de interpretação das normas postas - pois não se olvida que a decisão judicial é fonte do Direito e produz norma individual e concreta no exercício da função jurisdicional - e a possibilidade de criação do Poder Legislativo no momento de confecção das leis. Isso porque, como se disse, a maior parte da doutrina identifica o ativismo judicial com a extrapolação desse limite pelo Poder Judiciário.

Todavia, mesmo contrário ao ativismo judicial, Ramos afirma que ele pode, muitas vezes, ser elogiado por proporcionar a adaptação do direito diante de novas exigências sociais e de novas pautas axiológicas, em contraposição ao "passivismo", que, pautado no respeito das opções do legislador ou de precedentes poderia conduzir a uma estratificação dos padrões de conduta normativamente consagrados. ${ }^{311}$

A dificuldade encontra-se, como se disse, na identificação dos limites da atuação judicial, para que se evite a usurpação da função de elaboração de normas gerais e abstratas, função essencialmente política atribuída ao Legislativo, bem como para que se evite o engessamento do Direito e a inefetividade das normas constitucionais.

Quando se investiga suposto desvio no exercício da jurisdição, com ofensa ao princípio da separação de poderes, compete averiguar se existiu a desnaturação substancial da atividade. Para tanto, tradicionalmente, tomava-se como base a distinção entre o caráter meramente executório da jurisdição e a natureza criativa da legislação. Todavia, o próprio jurista Hans Kelsen assevera, na Teoria Pura do Direito, que:

A aplicação do Direito é simultaneamente produção do Direito. (...) É errado distinguir entre atos de criação e atos de aplicação do Direito. Com efeito, se

\footnotetext{
${ }^{310}$ FERREIRA FILHO. Manoel Gonçalves. Curso de Direito Constituicional. São Paulo: Saraiva, 2009, p.383

${ }^{311}$ RAMOS, Elival da Silva. Ativismo judicial: parâmetros dogmáticos. São Paulo: Saraiva, 2010, p. 110.
} 
deixarmos de lado os casos-limite - a pressuposição da norma fundamental e a execução do ato coercitivo - entre os quais se desenvolve o processo jurídico, todo ato jurídico é simultaneamente aplicação de uma norma superior e produção, regulada por essa norma, de norma inferior. ${ }^{312}$

Ainda, devemos ter em mente a evolução da hermenêutica, que tornou mais evidente o caráter dual da atividade jurisdicional, necessariamente criativa e inovadora. Isso porque, ao concretizarem a norma, geram a norma de decisão (do caso concreto), e esta não se limita a reproduzir os textos legislativos, os quais, pelo contrário, precisam ser desdobrados, adaptados e, por vezes, enriquecidos para poderem regular suficientemente a situação fática que deu causa à atuação jurisdicional.

A diferença verificada entre essa atuação descrita e aquela desenvolvida pelo legislador, no que tange à criação e inovação, reside na quantidade desta a que cada um deles está autorizado a utilizar no exercício de suas funções. Isso, principalmente, se considerarmos que o limite formal do Poder Legislativo é apenas as normas constitucionais, enquanto que o limite do Poder Judiciário é todo o plexo normativo positivado. Outra diferença é a de que, ainda que as decisões judiciais configurem-se como fonte de Direito e possam ser consideradas normas, o são apenas para o caso concreto, enquanto as leis editadas pelo Parlamento possuem caráter geral e abstrato, encontrando-se hierarquicamente acima daquelas, portanto.

A esse respeito, especificamente quanto à discricionariedade jurisdicional e legislativa, Kelsen enuncia que a diferença entre os dois casos é apenas quantitativa, não qualitativa, pois a vinculação material do legislador é muito menor que a do julgador, de modo que este pode desenvolver atividade criativa e inovadora, porém, em grau menor. ${ }^{313}$

Destaque-se, no entanto, que, tanto maior será a discricionariedade do magistrado quanto mais genéricos e indeterminados os conceitos utilizados no texto legislativo. A utilização de tais conceitos e a elaboração de normas com conteúdo aberto é característica da Constituição brasileira de 1988, que se pretendeu principiológica. Cuida-se de técnica legislativa utilizada propositadamente para deixar ao intérprete e aplicador das normas maior flexibilidade para alcançar as finalidades pretendidas pelo constituinte.

É de destacar que, para Ronald Dworkin, a ideia de ativismo judicial está associada a uma intensa participação do Judiciário na concretização dos valores constitucionais. Esse

\footnotetext{
312 KELSEN, Hans. Teoria Pura do Direito. 7. ed. São Paulo: Martins Fontes, 2006, p. 252-253.

${ }^{313}$ KELSEN, Hans. Teoria Pura do Direito. 7. ed. São Paulo: Martins Fontes, 2006, p. 368.
} 
jurista defende que a própria estrutura das normas constitucionais, frequentemente vazadas em linguagem altamente abstrata, que contém apelo direto a ideais políticos e filosóficos, convida o interprete a proceder a uma leitura moral do texto constitucional, de modo que, nesse aspecto, o neoconstitucionalismo se identifica com o "moralismo jurídico" (leitura moral da Constituição). ${ }^{314}$

Por sua vez, para Gadamer, a atividade interpretativa envolve muito mais que sujeito e objeto, pois é necessário compreender que a interpretação é feita por um sujeito, situado em um horizonte histórico, dentro de uma tradição, eivado de valores prévios, e é exatamente essa valoração pessoal que necessita de controle, que deve respeitar os limites da expressão textual da Constituição, sob pena de colocar em risco o Estado de Direito e menosprezar a atividade legislativa $^{315}$.

Com base na análise acima, é possível afirmar que o ativismo judicial pode ser encarado não apenas como uma atuação ilegítima e indesejável do Judiciário, mas também como o reflexo da adoção de um sistema de controle de constitucionalidade substancialista por parte do Poder Constituinte. Nesse sentido, o Ministro Celso de Mello, em discurso de 23 de abril de 2008, afirmou que "práticas de ativismo judicial, embora moderadamente desempenhadas por esta Corte em momentos excepcionais, tornam-se uma necessidade institucional.".

Daí que, em lugar de negar essa possibilidade, o que se propõe é aceitá-la como natural no novo papel a ser exercido pelo Judiciário no Estado Democrático de Direito ${ }^{316}$ e, a partir daí, buscar formas de controle sobre a atuação do Poder Judiciário violadora do compromisso democrático que deve permear a atividade jurisdicional. Isso porque,

(...) descumprir os dispositivos que consubstanciam o núcleo básico da constituição, isto é, aqueles que estabelecem os fins do Estado, (o que implica trabalhar com a noção de 'meios' aptos para a consecução dos fins), representa solapar o próprio contrato social (do qual a Constituição é elo que liga o político e o jurídico da sociedade). ${ }^{317}$

\footnotetext{
${ }^{314}$ DWORKIN, Ronald. Freedom's law: the moral reading of the American Constitution. Cambridge: Harvard University Press, 1996, p. 1-39.

${ }^{315}$ Cf. GADAMER, Hans-Georg. Verdade e método. Tradução de Flávio Paulo Meurer. Petrópolis: Vozes, 1997. 316 A esse respeito, ver STRECK, Lênio Luiz. A hermenêutica filosófica e a teoria da argumentação da ambiência do debate do 'positivismo (neo) constitucionalismo'. In: Diálogos constitucionais: direito, neoliberalismo e desenvolvimento em países periféricos. Rio de Janeiro: Renovar, 2006.

317 STRECK, Lênio Luis. Jurisdição constitucional e hermenêutica: uma nova crítica do Direito. Porto Alegre: Livraria do Advogado, 2002, p. 30.
} 
Nessa medida, voltamos à discussão apresentada no capítulo inaugural deste trabalho, principalmente no que diz respeito à evidência de que a separação dos Poderes de Montesquieu é insuficiente para explicar a nova distribuição das funções estatais entre os Poderes Judiciário, Legislativo e Executivo.

Isso porque há um abismo entre as circunstâncias do Estado Liberal que Montesquieu tinha em vista quando da elaboração de sua teoria e as circunstâncias do atual Estado Democrático de Direito. Ao contrário do que poderia supor o filósofo francês, o Poder Judiciário, dotado de nenhuma ou muito pouca expressão segundo sua teoria, foi aquele que mais se desenvolveu ao longo dos séculos, atingindo, hoje, destacado papel entre os Poderes estatais, com relevância primordial na análise de questões de importância para sociedade como um todo.

São diversas as circunstâncias que levaram o Poder Judiciário a atingir tal posição de destaque, como já referimos no segundo capítulo deste trabalho e neste próprio capítulo, ao tratar das causas para a disseminação da judicialização da política. Mencionamos, aqui, particularmente, o déficit democrático das próprias instituições representativas.

Com efeito, grande parte das causas do protagonismo judicial no século XXI deve-se precisamente a uma necessidade de restabelecimento da própria democracia sob o aspecto substancial, em especial no que se refere à realização dos direitos fundamentais dos cidadãos.

Daniel Sarmento, em análise sobre a objeção democrática à proteção dos direitos sociais, embora afirme não ser desejável que o Poder Judicário se transforme na principal agência de decisões sobre políticas públicas e que não se pode negligenciar os riscos que essa atuação traz para a democracia, apresenta três argumentos possíveis para refutar tal crítica.

O primeiro, como se disse, é o déficit democrático do Legislativo e do Executivo, o que afirma ser um problema universal, mas que, "no Brasil, há componentes que o agravam de forma exponencial, abalando profundamente a credibilidade das instituições de representação popular.". ${ }^{318}$ Isso pode ser constatado por meio de pesquisas de opinião pública, como a realizada por Alberto Carlos de Almeida com pessoas de todas as classes sociais e em todas as regiões do País, revelando baixíssima confiança da população no Congresso Nacional

\footnotetext{
${ }^{318}$ SARMENTO, Daniel. A proteção judicial dos direitos sociais: alguns parâmetros ético-jurídicos. In: SOUZA NETO, Cláudio Pereira; ____ (Coord.) Direitos sociais: fundamentos, judicialização e direitos sociais em espécie. Rio de Janeiro: Lumen Iuris, 2008, p. 560. Ainda, sobre a crise da democracia representativa, cf. BONAVIDES, Paulo. Teoria constitucional da democracia participativa. São Paulo: Malheiros, 2001.
} 
e nos partidos políticos. ${ }^{319}$ Pode ser constatado ainda por meio das diversas manifestações populares que tomaram as ruas brasileiras em meados do ano de 2013.

Em segundo lugar, Sarmento indica que, hoje, existe razoável consenso no sentido de que a democracia verdadeira exige mais do que eleições livres, com sufrágio universal e possibilidade de alternância no poder. Diferente disso, é difundida também a ideia de que a democracia pressupõe o gozo de direitos básicos por todos os cidadãos, de tal modo que quando o Poder Judiciário garante esses direitos fundamentais contra os descasos ou as arbitrariedades das maiorias políticas ou dos tecnocratas de plantão, pode-se dizer que ele está, a rigor, protegendo os pressupostos para o funcionamento da democracia, e não atuando contra ela. ${ }^{320}$

Por fim, o terceiro argumento apresentado por Sarmento é o de que o dever do Poder Judiciário de aplicar as normas constitucionais em situações de litígio, mesmo quanto isto implique em controlar o exercício do poder estatal, não é incompatível com a democracia, mas antes um elemento dela. Isso porque, sendo a Constituição uma autêntica norma jurídica, a consagração de direitos em seu texto deveria afastar a objeção contra o suposto caráter antidemocrático da adjudicação desses direitos, pois o Judiciário estaria apenas desempenhando sua função típica de aplicar o direito. ${ }^{321}$

Sob esse aspecto, após a promulgação da Constituição de 1988, que instalou o Estado Democrático de Direito no Brasil, o Poder Judiciário ganhou contornos próprios para sua atuação independente e efetiva no que se refere à guarda das normas constitucionais, tendo o Supremo Tribunal Federal sido fartamente equipado com instrumentos para o controle externo dos demais Poderes, inclusive com a possibilidade de suprir a omissão deles.

Apesar das críticas relacionadas acima, não há dúvida de que, no desempenho de sua função política, especialmente no exercício do controle de constitucionalidade, o Supremo Tribunal Federal tem o potencial de estimular o jogo democrático e a atuação satisfatória dos atores políticos, por meio do estabelecimento de uma nova dinâmica da separação de Poderes,

\footnotetext{
${ }^{319}$ ALMEIDA, Alberto Carlos. A cabeça do brasileiro. Rio de Janeiro: Editora Record, 2007, p. 189. Apud SARMENTO, Daniel. A proteção judicial dos direitos sociais: alguns parâmetros ético-jurídicos. In: SOUZA NETO, Cláudio Pereira; ___ (Coord.) Direitos sociais: fundamentos, judicialização e direitos sociais em espécie. Rio de Janeiro: Lumen Iuris, 2008, p. 560.

${ }^{320}$ SARMENTO, Daniel. A proteção judicial dos direitos sociais: alguns parâmetros ético-jurídicos. In: SOUZA NETO, Cláudio Pereira; ___ _ (Coord.) Direitos sociais: fundamentos, judicialização e direitos sociais em espécie. Rio de Janeiro: Lumen Iuris, 2008, p. 561.

${ }^{321}$ SARMENTO, Daniel. A proteção judicial dos direitos sociais: alguns parâmetros ético-jurídicos. In: SOUZA NETO, Cláudio Pereira; ___ (Coord.) Direitos sociais: fundamentos, judicialização e direitos sociais em espécie. Rio de Janeiro: Lumen Iuris, 2008, p. 561.
} 
especialmente no que se refere à relação entre os Poderes Judiciário e Legislativo, a partir de um diálogo deliberativo entre o Supremo Tribunal Federal e o Congresso Nacional, como veremos a seguir.

3.3. Proposta da interação deliberativa entre o STF e o Congresso Nacional como expressão da separação de Poderes

De acordo com o exposto até aqui, apesar de as críticas ao Supremo Tribunal Federal contarem com o apoio de grandes juristas, não se pode olvidar que a revisão judicial realizada pela Corte exerce relevante papel para a concretização da Constituição, seja no que se refere à manutenção das estruturas democráticas, seja na efetivação de direitos fundamentais.

Além desse evidente benefício, passa-se a destacar também o importante reflexo da atuação expandida do Supremo Tribunal Federal sobre a relação entre os Poderes Legislativo e Judiciário, estabelecendo uma espécie de diálogo entre eles. Tal diálogo, como se verá adiante, pode ser entendido basicamente como uma relação de ação e reação no debate sobre questões políticas entre o Supremo Tribunal Federal e o Poder Legislativo, de modo que as decisões de um ou outro sejam construídas a partir de trocas argumentativas.

Essa proposta de relação entre os Poderes insere-se no contexto de atualização da teoria propugnada por Montesquieu, já referida no capítulo inicial deste trabalho. Desse modo, a ideia de estabelecimento de um diálogo entre os Poderes atende à necessária reacomodação das funções de cada um deles, de acordo com as novas perspectivas constitucionais do Estado Democrático de Direito.

No Brasil, boa fonte para a análise das teorias do diálogo entre Poderes é o livro de Conrado Hübner Mendes, Direito fundamentais, separação de poderes e deliberação, razão por que parte-se dela para a presente abordagem do tema. Nessa obra, o autor sugere que, por meio da prática do diálogo deliberativo entre o Supremo Tribunal Federal e o Congresso Nacional, é possível (i) mitigar a ideia subjacente à teoria de separação de Poderes clássica, segundo a qual deve haver um único Poder a quem se possa imputar "o direito de errar por último" no que se refere à interpretação constitucional, e (ii) conciliar as críticas e elogios que 
podem ser feitos ao legislador com as críticas e elogios que podem ser feitos aos juízes incluindo-se, aqui, a questão da legitimidade democrática. ${ }^{322}$

Assim, o autor afirma que as teorias do diálogo entre as instituições trazem algo de novo para a forma como a separação de Poderes é concebida. Elas procuram amenizar a preocupação com a "dificuldade contramajoritária", expressão de Alexander Bickel, pretendendo-se como um meio termo para a armadilha da "última palavra". Dentre as diversas nuances das teorias do diálogo, são dois os denominadores comuns: a rejeição da visão juricêntrica e do monopólio judicial na interpretação da constituição, a qual é e deve ser legitimamente exercida pelos outros poderes; a rejeição da existência de uma última palavra, ou, pelo menos, de que a Corte a detenha por meio da revisão judicial. ${ }^{323}$

As teorias do diálogo podem ser divididas em duas categorias gerais, decantadas por Conrado Hübner Mendes a partir da classificação de Christine Bateup, em seu The dialogic promise: assessing the normative potential theories of constitucional dialogue:

A primeira propõe uma teoria da decisão judicial que leve em conta a
interação com o legislador. Não se trata propriamente de um método de
interpretação, mas de uma demanda de que a corte reconheça e participe do
diálogo. É uma forma de compreensão normativa do seu papel. A segunda
define o diálogo como produto necessário da separação de poderes, uma
decorrência do desenho institucional, não necessariamente da disposição de
qualquer dos poderes por "dialogar". Nessa categoria, teorias são
predominantemente empíricas, mas a fronteira entre argumentos positivos e
normativos torna-se gradualmente nebulosa. Com frequência, proposições
descritivas influenciam o próprio comportamento das instituições que
participam do diálogo, o qual passa a ser uma razão invocada para a escolha
decisória (....).

Após detalhada análise da ideia de autores que defendem uma ou outra dessas categorias, tanto nos Estados Unidos quanto no Canadá e outros países da Commonwelth,

\footnotetext{
${ }^{322}$ Traz-se à lume o corte metodológico realizado pelo autor quanto aos Poderes estatais incluídos nesse estudo, justificativa que também adotamos para o presente trabalho: "Uma abordagem integral da separação de poderes através da "perspectiva dialógica" requereria também a análise de como o Executivo participa nesse processo. Este trabalho, porém, concentra-se numa versão incompleta de uma teoria mais ampla. Esse foco restrito à relação entre o parlamentos e cortes é a opção tradicional da teoria constitucional e tem uma razão de ser: o Poder Executivo nunca foi considerado como um candidato para a última palavra em questão de direitos fundamentais." MENDES, Conrado Hübner. Direito fundamentais, separação de poderes e deliberação. São Paulo: Saraiva, 2011, p. 105.

${ }^{323}$ MENDES, Conrado Hübner. Direito fundamentais, separação de poderes e deliberação. São Paulo: Saraiva, 2011, p. 107.

${ }^{324}$ MENDES, Conrado Hübner. Direito fundamentais, separação de poderes e deliberação. São Paulo: Saraiva, 2011, p. 107.
} 
Conrado Hübner parte desse conjunto de ideias para discorrer sobre a teoria do diálogo sob ponto de vista da deliberação, ${ }^{325}$ para afirmar que

Ao tratar de um modelo de interação que se oriente por princípios deliberativos e que se preocupe em dar criar uma "cultura da jusitificação" para além de um puro jogo de forças, tento defender um tipo mais desejável de "reatividade política", em que o bom argumento cumpra algum papel. Se parlamentos e cortes adotam uma atitude deliberativa e levam em conta os argumentos expostos por cada um, desafiando-se reciprocamente quando consideram que têm uma melhor alternativa, é provável que produzam respostas mais criativas do que num modelo de conflito adversarial. ${ }^{326}$

Nessa medida, conclui que a revisão judicial não precisa ser vista apenas como uma barreira de contenção das decisões dos atores políticos, mas também como um mecanismo de propulsão de melhores deliberações, um "catalisador deliberativo". E, sob essa perspectiva, inicia a análise do caso brasileiro, do diálogo entre Congresso Nacional e Supremo Tribunal Federal, criticando a aceitação tranquila deste como guardião da Constituição. ${ }^{327}$

Segundo a proposta de Hübner, de que o desempenho deliberativo seja a métrica para se construir um modelo de separação de Poderes, não meramente defensivo, mas com potencial epistêmico, a retórica do guardião da Constituição é incompatível com a noção de interação deliberativa e estimula uma dinâmica "adversarial" que desperdiça o potencial epistêmico da separação de Poderes. Assim,

Ao arrogar-se a responsabilidade de, olímpica e solidariamente, salvar a democracia contra a vontade dos outros poderes, a corte arrisca-se a criar um feitiço contra si mesma que tende a culminar ou numa prática decisória tímida e acanhada, ou numa reação mais agressiva (e menos deliberativa) do outro poder.

$(\ldots)$

Nesse sentido, defendo ser preferível um tribunal comedido e modesto na retórica, que se enxerga como participante de um processo interinstitucional de construção do significado da constituição e que não se intimida em ser ativista quando detentor de um bom argumento, a um tribunal verborrágico, mas pouco corajoso no desafio ao legislador. À medida que amansa retórica e investe seriamente o seu desempenho deliberativo, o STF pode construir

\footnotetext{
${ }^{325}$ Não procuraremos adentrar em tais detalhes sobre a análise realizada por Conrado Hübner Mendes ao longo de mais de 100 páginas, em razão da infinidade de minúcias que não cabem ser examinadas no presente trabalho. Para aprofundamento, portanto, cf. MENDES, Conrado Hübner. Direito fundamentais, separação de poderes e deliberação. São Paulo: Saraiva, 2011, p. 105-211.

${ }^{326}$ MENDES, Conrado Hübner. Direito fundamentais, separação de poderes e deliberação. São Paulo: Saraiva, 2011 , p. 210.

${ }^{327}$ MENDES, Conrado Hübner. Direito fundamentais, separação de poderes e deliberação. São Paulo: Saraiva, 2011, p. 214.
} 
melhores condições políticas para intervir com maior intensidade. Pratica ativismo não para se impor, mas para provocar reações. ${ }^{328}$

O autor admite que a Constituição de 1988 reservou ao Supremo Tribunal Federal, em razão da estrutura do sistema de controle de constitucionalidade, a "última palavra" provisória, de modo que a cultura constitucional brasileira, razoavelmente majoritária, vê no Supremo Tribunal Federal a autoridade última e monopolística para revelar o significado da constituição. Ocorre que isso não só desestimula como também isenta o legislador de desafiar o Judiciário com novos argumentos. Segundo esse pensamento, se o Supremo Tribunal Federal decide, nada mais pode ser feito para alterar essa decisão; dificilmente se percebe tal decisão como apenas um evento de uma corrente, um estágio do processo.

Não obstante, a compreensão da interação entre as instituições e a avaliação de sua respectiva legitimidade requer que se considere não apenas o que elas fazem, mas também o que deixam de fazer. É o que o se chama de agenda ativa e agenda passiva das instituições, de tal modo que ações e omissões não são legítimas ou ilegítimas por si sós, mas dependem do contexto em que são praticadas.

Com base na ação ou omissão do Supremo Tribunal Federal e do Congresso Nacional, Hübner identifica quatro tipos de pauta que essas instituições podem experimentar. São elas: (i) a pauta reprimida, em que se identifica a tensão e o debate público informal, porém, não foi canalizada à Corte ou ao legislador; (ii) a pauta estabilizada, que reflete decisões bens acomodadas, produto de rodadas deliberativas anteriores; (iii) a pauta congelada, em que os temas já foram provocados, mas aguardam decisão, seja na Corte seja no Parlamento; e (iv) a pauta aquecida, em que os temas permanecem em evidência na ordem do dia, ou seja, que não se estabilizaram apesar de diversas rodadas deliberativas entre a Corte e o legislador. ${ }^{329}$

$\mathrm{O}$ autor afirma que as pautas congelada e aquecida ensejam situações mais visíveis de diálogo institucional. Em relação à pauta constitucional aquecida, é de se esperar que haja a coexistência de ativismo legislativo e judicial até que, eventualmente, essas tensões se estabilizem, como, por exemplo, por meio de uma decisão judicial que reconheça a constitucionalidade de um ato legislativo. Hübner considera esta a situação ideal de diálogo institucional.

\footnotetext{
${ }^{328}$ MENDES, Conrado Hübner. Direito fundamentais, separação de poderes e deliberação. São Paulo: Saraiva, 2011, p. 214-215.

${ }^{329}$ MENDES, Conrado Hübner. Direito fundamentais, separação de poderes e deliberação. São Paulo: Saraiva, 2011, p. 220.
} 
Pode-se verificar também a situação em que Corte e legislador ficam inertes, isto é, as instituições são acionadas, mas não se manifestam. A inércia legislativa corresponde à situação em que, apesar das exigências constitucionais, o legislador não se manifesta ou se manifesta de forma insuficiente - trata-se do caso das omissões inconstitucionais, que podem ser totais ou parciais. Na inércia judicial, a Corte recebe o caso, mas simplesmente não o inclui em sua pauta de julgamento.

No caso exposto, de pauta congelada, é mais fácil o "aquecimento" dela quando a inércia se dá pelo Parlamento, tendo em vista a existência de instrumentos próprios para isso, o mandado de injunção ou a ação direta de inconstitucionalidade por omissão. Por sua vez, não é difícil notar que não há instrumentos correlatos para o controle da inércia do Supremo Tribunal Federal. O que fazer quando a Corte, estrategicamente, decide não julgar um caso? Embora ela esteja vinculada ao princípio do non liquet, sabe-se que cabe ao próprio Supremo decidir a sua pauta de julgamentos. Segundo Hübner, não há instrumentos formais para tanto, todavia, menciona o caso das células-tronco, em que a pressão pública foi decisiva para o seu julgamento. Trata-se, como diz o autor, de um vácuo teórico. ${ }^{330}$

A fim de justificar a pertinência do debate sobre o diálogo institucional no Brasil e de demonstrar que, mesmo de forma insipiente, ele se faz ver em alguns momentos da relação entre a Corte e o Congresso, o autor menciona alguns episódios de interação entre o Supremo Tribunal Federal e o Parlamento, os quais mostram que o legislador, ordinário ou constituinte, reage ao Supremo com frequência e procura, de uma maneira ou de outra, argumentar.

Dentre as evidências de reação legislativa ao Supremo Tribunal Federal, refira-se o caso da cláusula de barreira (Ação direta de inconstitucionalidade n. 1.351 e 1.354), no qual, diante da declaração de inconstitucionalidade do artigo 13 da Lei n. 9.096/95, o Senado se movimentou, lançando mão de uma Proposta de Emenda Constitucional (PEC 02/2007) que prevê o retorno da cláusula de barreira. No parecer que fundamenta a proposta, há uma longa análise dos argumentos do Supremo. Tal análise esclarece como, na atual proposta, um novo tipo de cláusula de barreira pôde ser criado sem que defronte com a interpretação da Corte.

A mesma situação de reação legislativa se pôde verificar no caso da união estável homoafetiva. Após o Supremo Tribunal Federal ter reconhecido a união estável entre casais do mesmo sexo (Ação direta de inconstitucionalidade n. 4.277 e a Arguição de descumprimento de preceito fundamental n. 132), a Senadora Marta Suplicy apresentou ao

\footnotetext{
${ }^{330}$ MENDES, Conrado Hübner. Direito fundamentais, separação de poderes e deliberação. São Paulo: Saraiva,
} 2011, p. 224. 
Senado o Projeto de Lei n. 612/2011, ${ }^{331}$ que visa à alteração dos artigos 1.723 e 1.726 do Código Civil para reconhecer como entidade familiar a união estável entre pessoas do mesmo sexo e sua conversão em casamento. A justificação do projeto de lei expressamente se refere à necessidade de reação (ratificadora, neste caso) do Legislativo à decisão do Supremo Tribunal Federal.

Como neste exemplo, o legislador, quando aceita a posição do Supremo, nem sempre o faz por pura passividade ou deferência; quando tenta resistir e procurar novas vias para o mesmo fim legislativo que fora combatido pela Corte, tampouco recorre à pura pressão política ou sutis manifestações de força. Ao contrário, tem dedicado, nessas reações, atenção explícita às razões apresentadas pelo Supremo Tribunal Federal. ${ }^{332}$

Por fim, episódios de controle da omissão do legislador também abrem um caminho para a compreensão e justificação do papel do Supremo de catalisar um debate bloqueado no Parlamento. Pode-se citar como exemplo o caso do direito de greve dos servidores públicos e da fidelidade partidária - ambos casos já referidos anteriormente, quando do exame do ativismo judicial.

Importante destacar, contudo, o esclarecimento de Hübner no sentido de que, apesar da ocorrência desses casos, isso não significa que esteja acontecendo um diálogo genuíno entre a Corte e o Congresso Nacional, muito menos o modelo de diálogo deliberativo que entende ser desejável para democracia. Entretanto, os casos podem, sim, demonstrar que a Corte e o Parlamento vem interagindo em alguma medida, intercambiando argumentos. $\mathrm{O}$ autor sugere, por fim, que ainda prevalece dentre os Ministros do Supremo a visão de que a Corte detém o poder de dar a última palavra na interpretação constitucional, de tal modo que, caso o Legislativo queria participar dessa tarefa, não pode se mostrar acanhado em face de "posições juricêntricas” do Supremo Tribunal Federal. ${ }^{333}$

Em suma, segundo Jeffrey Tullis, autor em quem se respalda Conrado Hübner, é necessária a inclusão da ideia de deliberação no centro da teoria da separação de Poderes, com base na "premissa de que nenhuma instituição democrática específica é suficiente para assegurar a consideração de todas as preocupações relevantes na sustentação da

\footnotetext{
331 Texto do Projeto de Lei n. 612/2011 verificado a partir do site do Senado Federal. Disponível em: http://legis.senado.leg.br/mateweb/arquivos/mate-pdf/97352.pdf. Acesso em: 16 out. 2013.

${ }_{332}$ MENDES, Conrado Hübner. Direito fundamentais, separação de poderes e deliberação. São Paulo: Saraiva, 2011 , p. 226.

${ }^{333}$ MENDES, Conrado Hübner. Direito fundamentais, separação de poderes e deliberação. São Paulo: Saraiva, 2011, p. 235.
} 
democracia.". ${ }^{334}$ Ora, a separação de Poderes faz com que diferentes valores (como a vontade popular, a linguagem dos direitos, a pressão por eficiência etc.) entrem em tensão, de modo que essa tensão deliberativa entre instituições que competem pode ser funcional para a produção de boas decisões.

Sob esse ponto de vista, a deliberação parece, de fato, poder trazer benefícios ao debate político democrático, maiores do que o mero controle externo propalado pelo sistema de checks and balances e, sem dúvida alguma, muito mais adequados à realidade dinâmica e complexa do Estado Democrático de Direito.

${ }^{334}$ TULIS, Jeffrey. Deliberation between institutions. In: LASLETT, Peter; FISHKIN, James (Ed.). Debating deliberative democracy. Malden: Blackwell, 2003, p. 203. 


\section{CONSIDERAÇÕES FINAIS}

Como já explicitado, o principal objetivo neste trabalho foi o de depreender se a atuação do Supremo Tribunal Federal, após a promulgação da Constituição de 1988, passou a repercutir no equilíbrio entre os Poderes, especialmente na relação entre Judiciário e Legislativo.

Com tal fito, inicialmente, procedeu-se à análise da Teoria de Separação de Poderes de Montesquieu, já que foi esta a primeira proposta efetivamente sistematizada de organização dos Poderes e de atribuição a cada um deles de funções definidas. Verificou-se, no entanto, que a tal teoria tem sido observada sob uma óptica "juridicista e simplificada", ${ }^{335}$ que lhe conferiu caráter muito mais estático do que parece ter pretendido Montesquieu.

De tal sorte, foi apurado que a Teoria da Separação de Poderes, ao longo de sua aplicação a determinados modelos de Estado, sofreu algumas adaptações, principalmente nos Estados Unidos da América, onde foi desenvolvida a teoria dos checks and balances, já como forma que mitigar a rigidez da teoria montesquiana, promovendo maior colaboração entre os Poderes.

Verificou-se também que, ao longo da evolução do Estado, a partir do século XIX, houve a incidência do fenômeno do protagonismo dos Poderes, de modo que, no Estado Liberal, destacou-se o Legislativo; no Social, o Executivo; e, hoje, no Democrático de Direito, o Judiciário. Com efeito, o estudo das relações entre os Poderes e do fenômeno do protagonismo de cada um deles implica na compreensão de que, ainda que o modelo tripartite de Montesquieu venha servindo como base para a organização dos Poderes, desde a sua inserção nas constituições promulgadas no contexto das Revoluções Liberais, a organização e a distribuição das funções estatais não escapa à natural necessidade de adaptação dos Poderes às circunstâncias políticas, sociais e econômicas verificadas em determinados momentos históricos.

\footnotetext{
${ }^{335} \mathrm{Cf}$. nota de rodapé 37.
} 
Desse modo, concluiu-se, com André Ramos Tavares, que o Judiciário foi retirado de uma posição submissa, para se transformar, no fim do século XX e início do século XXI, em Poder de crucial importância na manutenção da ordem social. ${ }^{336}$

Feita essa análise, passamos a tratar do caso brasileiro de separação de Poderes, com destaque ao Judiciário e ao Legislativo, pois, como se disse, este é o embate em maior evidência atualmente, além de nos despertar especial interesse em face da discussão final da dissertação, relativa ao impacto do Supremo Tribunal Federal, no exercício do controle de constitucionalidade, sobre as relações deliberativas entre Legislativo e Judiciário.

Nesse sentido, analisamos a separação de Poderes na Constituição de 1988, evidenciando o crescimento do Poder Judiciário em contraposição a um enfraquecimento do Poder Legislativo, e examinamos os fatores que determinaram tamanha expansão judicial, sobretudo no que respeita à jurisdição constitucional, analisando detidamente as questões da consolidação do controle de constitucionalidade e da "nova" interpretação constitucional.

Em síntese, por intermédio dos diversos instrumentos processuais trazidos pela Constituição, como o mandado de injunção, a ação direta de inconstitucionalidade por omissão, a arguição de descumprimento de preceito fundamental, entre outros, o Supremo Tribunal Federal foi posto em destaque na vida político-social. Além disso, o protagonismo do Poder Judiciário foi impulsionado também pela "nova" interpretação constitucional, por meio do que o Poder Judiciário passa a ter maior participação na interpretação e especificação das normas de conteúdo aberto, deixando de ser mero guardião passivo, posição que ocupava no Estado Liberal, para tornar-se promotor ativo do que se pode chamar de programaticidade dirigente constitucional. ${ }^{337}$

Por sua vez, ao longo do terceiro capítulo, procurou-se demonstrar que o Supremo Tribunal Federal exerce função política por meio de grande parte de suas competências e que essa atuação tem relação com as questões da "judicialização da política" e do "ativismo judicial”. Com efeito, foi possível apontar alguns casos em que há consenso, se não sobre o ativismo do Supremo, sobre uma atuação destacadamente política.

Com relação a tal comportamento, apresentamos algumas críticas quanto ao exercício de função política por aquela Corte, as quais estão centradas em duas questões especialmente problemáticas, a da legitimidade da Corte para rever decisões políticas dos Poderes

\footnotetext{
${ }^{336}$ Cf. nota de rodapé 110 .

337 DANTAS, Miguel Calmon. Constitucionalismo dirigente e pós-modernidade. São Paulo: Saraiva, 2009, p. 355 e ss.
} 
Legislativo e Executivo (cujos membros são eleitos pelos cidadãos e representam indiretamente a sua vontade) e a violação à separação dos Poderes.

Todas as questões apresentadas neste último capítulo estão ligadas, por relação de causa e consequência, às discussões apresentadas nos capítulos antecedentes: de modo global, a insuficiência da Teoria da Separação de Poderes de Montesquieu, devido às novas circunstâncias do Estado Democrático de Direito (vide Capítulo 1), e à nova acomodação entre os Poderes estatais no Brasil, notadamente o Legislativo e o Judiciário, tendo o Judiciário ganhado notório destaque no cenário político após a promulgação da Constituição de 1988 (vide Capítulo 2).

Assim, partindo da premissa de que, de fato, o Estado Democrático de Direito, no Brasil, instaurado pela Constituição de 1988, demandou a reacomodação das funções dos Poderes estatais e que o Judiciário passou a desempenhar relevante função política, principalmente por meio do Supremo Tribunal Federal, interessou-nos observar se tal atuação impactou o equilíbrio de Poderes, especialmente no que se refere a eventuais consequências para o diálogo entre o Poder Judiciário e o Poder Legislativo.

Desse modo, com base na obra Direitos fundamentais, separação de poderes $e$ deliberação, de Conrado Hübner Mendes, ${ }^{338}$ encerrou-se esta dissertação examinando o influxo da atuação até aqui verificada do Supremo Tribunal Federal sobre a relação entre os Poderes Legislativo e Judiciário.

Segundo Conrado Hübner Mendes, atualmente, para além da competição entre o Supremo Tribunal Federal e o Congresso Nacional, vislumbra-se a possibilidade de estabelecimento de uma espécie de diálogo deliberativo entre eles, o que seria mais benéfico para a construção do debate democrático.

A proposta de diálogo deliberativo insere-se no contexto de atualização da separação dos Poderes propugnada por Montesquieu, tendo em vista a necessária reacomodação das funções de cada um deles, de acordo com as novas perspectivas constitucionais do Estado Democrático de Direito, parecendo-nos, efetivamente, uma saída possível para que se estabeleça uma nova dinâmica, mais legítima, para a democracia e para a relação entre os Poderes.

\footnotetext{
${ }^{338}$ MENDES, Conrado Hübner. Direito fundamentais, separação de poderes e deliberação. São Paulo: Saraiva, 2011.
} 
É de observar, contudo, que esse diálogo somente pode ocorrer em havendo iniciativa do Supremo e do Congresso Nacional e fazê-lo. Ao concluir seu trabalho, Hübner diz que o Congresso não pode se acanhar em face do ativismo do Supremo Tribunal Federal, sob pena de prejudicar o diálogo entre essas duas instituições e sob pena também de deixar ao arbítrio (nos limites da Constituição, claro) da Corte a decisão sobre questões candentes no debate público.

No entanto, como observado no Capítulo 2 desta dissertação, o Congresso Nacional, em diversos casos, opta por se manter inerte, principalmente quanto a temas de alto custo político, esperando que a decisão sobre elas seja conferida pelo Supremo Tribunal Federal. É o que se pôde verificar do caso da união estável homoafetiva. Eventual decisão sobre esse tema na seara legislativa provocaria forte reação dos eleitores: seja dos insatisfeitos com seus representantes devido a edição de lei favorável aos casais homossexuais, seja dos insatisfeitos com seus representantes devido a edição de lei desfavorável.

O diálogo entre as instituições, portanto, embora necessário, encontra diversas dificuldades no cenário político e eleitoral brasileiro. É sob essa perspectiva que entendemos deva ser abordada a legitimidade democrática da Corte para julgamento de questões políticas. O próprio Poder Legislativo, hoje, parece conferir legitimidade ao Supremo, no sentido de que esperam que temas como a união homoafetiva possa ser decidida em um campo neutro.

Neste trabalho, pretendeu-se, portanto, contribuir não apenas para a revisão bibliográfica da Teoria da Separação de Poderes de Montesquieu à luz do Estado Democrático de Direito e da atuação do Supremo Tribunal Federal. Pretendeu-se iniciar o debate acerca de uma nova dinâmica entre os Poderes, em que se leve em consideração a multiplicidade de funções exercidas por eles em face de um complexo cenário político, propondo-se um aprofundamento futuro acerca da proposta de compreensão da separação de Poderes diante do estabelecimento de um diálogo interinstitucional. 


\section{Referências bibliográficas}

ACOSTA SÁNCHEZ, José. Formación de la Constitución y Jurisdicción Constitucional. Madrid: Tecnos, 1998.

ACKERMAN, Bruce. A nova separação dos poderes. Rio de Janeiro: Lumen Juis, 2013.

ALEXY, Robert. Teoria dos direitos fundamentais. Tradução de Virgílio Afonso da Silva. São Paulo: Malheiros, 2008.

ALMOND, Gabriel; COLEMAN, James. The politics of developing areas. Princeton: Princeton University Press, 1960.

ALVES JR., Luís Carlos Martins. O Supremo Tribunal Federal nas Constituições brasileiras. Belo Horizonte: Mandamentos, 2004, p. 128.

ARANTES, Rogério Bastos. Constitucionalism, the expansion of Justice and the judicialization of politics in Brazil In: SIEDER, Rachel; SCHJOLDEN; ANGELL, Alan. The judicialization of politics in Latin America. Nova York: Palgrave Macmillan, 2006, p. 231.

ARISTÓTELES. A Política. Tradução de Roberto Leal Ferreira. 3. ed. São Paulo: Martins Fontes, 2006.

BANDEIRA DE MELLO, Oswaldo Aranha. Teoria das constituições rígidas. 2. ed. São Paulo: Bushatsky, 1980.

BARBOSA, Rui. Os atos inconstitucionais do Congresso e do Executivo. In: Trabalhos jurídicos. Rio de Janeiro: Casa de Rui Barbosa, 1962.

BARROS, Sérgio Resende de. "Leis" autorizativas. Revista do Instituto de Pesquisas e Estudos. Divisão Jurídica, Bauru, n. 29, ago/nov. 2000.

Sérgio Resende de. Estudo sobre o “impeachment”. Disponível em: http://www.srbarros.com.br/pt/estudo-sobre-o-impeachment.cont. Acesso em: 23 Out. 2013.

BARROSO, Luís Roberto. O controle de constitucionalidade no Direito Brasileiro. 5. ed. São

Paulo: Saraiva, 2011. 
O novo direito constitucional brasileiro: contribuições para a construção teórica e prática da jurisdição constitucional no Brasil. Belo Horizonte: Fórum, 2013.

Judicialização, ativismo judicial e legitimidade democrática. Revista de Direito do Estado, Rio de Janeiro, n. 13, jan/mar. 2009, p. 77.

BASTOS, Celso Seixas Ribeiro. Curso de direito constitucional. Revisão e atualização de Samantha Meyer-Pflug. 22. ed. São Paulo: Malheiros, 2010.

2003.

Hermenêutica e interpretação constitucional. 3. ed. São Paulo: Celso Bastos Editor,

BATISTA JUNIOR, Edil. O Supremo Tribunal Federal e o monopólio da hermenêutica constitucional no Brasil. Curitiba: Juruá, 2011.

BEÇAK, Rubens. A hipertrofia do Executivo brasileiro: impacto da Constituição de 1988. 2005. 184 p. Tese (Doutorado) - Faculdade de Direito da Universidade de São Paulo, São Paulo. 2005.

O Tribunal Constitucional e sua intervenção no processo político. Disponível em: www.conpedi.org.br/manaus/arquivos/anais/salvador/rubens_becak.pdf. Acesso em: 20 Ago. 2012.

A separação de Poderes, o Tribunal Constitucional e a judicialização da política. Revista da Faculdade de Direito da Universidade de São Paulo FDUSP. Faculdade de Direito da Universidade de São Paulo FDUSP, v. 103, p. 325-336, 2008.

O Tribunal Constitucional como regulador do processo político. Boletim Eletrônico da Escola Paulista de Direito. Boletim Eletrônico da Escola Paulista de Direito - EPD, v. 1, p. 2757-2772, 2007.

BERCOVICI, Gilberto. O impasse da democracia representativa. In: ROCHA, Fernando Luiz Ximenes; MORAES, Filomeno (Org.). Direito Constitucional Contemporâneo: estudos em homenagem ao professor Paulo Bonavides. Belo Horizonte: Del Rey, 2005.

BICKEL, Alexander M. The least dangerous branch: the Supreme Court at the bar of politics. New Haven: Yale University Press, 1986. 
BITTENCOURT, Carlos Alberto Lúcio. O controle jurisdicional de constitucionalidade das leis. 2. ed. Rio de Janeiro: Forense, 1968.

BOBBIO, Norberto. A teoria das formas de governo. Tradução de Sérgio Bath. 10. ed. Brasília: UnB, 1998.

A era dos direitos. Rio de Janeiro: Campus Elsevier, 2004.

BODIN, Jean. Os seis livros da República: livro primeiro. Traduzido por José Ignácio Coelho Mendes Neto. São Paulo: Editora Ícone, 2011. (Coleção Fundamentos do Direito)

BONAVIDES, Paulo. Do Estado Liberal ao Estado Social. 9. ed. São Paulo: Malheiros, 2009.

Curso de direito constitucional. 25. ed. São Paulo: Malheiros, 2010.

; ANDRADE, Paes de. História constitucional do Brasil. 8. ed. São Paulo: OAB Editora, 2006.

Teoria constitucional da democracia participativa. São Paulo: Malheiros, 2001.

BRASIL. Constituição (1988). Constituição da República Federativa do Brasil. Brasília: Senado Federal, 1988.

BRITTO, Carlos Ayres. Separação de poderes na Constituição brasileira. Revista de Direito Público, n. 59/60, p. 115-127, jul./dez. 1981.

BURDEAU, Georges. Remarques sur la classification des fonctions étatiques. Revue du Droit Public, Paris, n. 60, p. 202-228, 1945, p. 214.

CAEtAnO, Marcello. Manual de Ciência Política e Direito Constitucional. t. I. 6. ed. Lisboa: Almedina, 2006.

CAGGIANO, Monica Herman Salem. O Parlamento no cenário político do século XXI. Revista do Advogado, São Paulo, n. 73, p. 146-166, Nov. 2003. (Estudo de Direito Constitucional em homenagem a Celso Ribeiro Bastos). 
A emergência do Poder Judiciário como contraponto ao bloco monomotor Legislativo/Executivo. In: MORAES, Alexandre (Coord.). Os 20 anos da constituição da Republica Federativa do Brasil. São Paulo: Atlas, 2009. p. 99-123.

CAMBI, Eduardo. Neoconstitucionalismo e neoprocessualismo: direitos fundamentais, políticas públicas e protagonismo judiciário. São Paulo: RT, 2009.

CAMPANHOLE, Hilton Lobo; CAMPANHOLE, Adriano. Constituições do Brasil. 14. ed. São Paulo: Atlas, 2000.

CAMPILONGO, Celso. Os desafios do Judiciário: um enquadramento teórico. In: FARIA, José Eduardo (Org.). Os direitos humanos, direitos sociais e justiça. São Paulo: Malheiros, 2002. p. 30-51.

CANOTILHO, Joaquim José Gomes. Direito constitucional e teoria da constituição. 7. ed. Coimbra: Almedina, 2003.

CAPPELLETTI, Mauro. Juízes legisladores? Tradução de Carlos Alberto Álvaro de Oliveira. Porto Alegre: Sérgio Antonio Fabris, 1993.

CASTRO, Marcus Faro de. O Supremo Tribunal Federal e a judicialização da política. Revista Brasileira de Ciências Sociais. São Paulo, v. 12, n. 34, p. 147-156, 1997.

CLÈVE, Clèmerson Merlim. Atividade legislativa do Poder Executivo. 3. ed. São Paulo: RT, 2011.

CORRÊA, Oscar Dias. A crise da constituição, a constituinte e o Supremo Tribunal Federal. São Paulo: RT, 1986.

COSTA, Emília Viotti da. O Supremo Tribunal Federal e a construção da cidadania. 2. ed. São Paulo: Editora UNESP, 2006.

CITTADINO, Gisele. Judicialização da política, constitucionalismo democrático e separação de poderes. In: VIANNA, Luiz Werneck (Org.). A democracia e os três Poderes no Brasil. Belo Horizonte: UFMG, Rio de Janeiro: IUPERJ/FAPERJ, 2003. 
COMPARATO, Fabio Konder. O processo de impeachment e a importância constitucional do caso Collor. In: ROSENN, Keith S.; DOWNES, Richard (Org.). Corrupção e reforma política no Brasil: o impacto do impeachment de Collor. Rio de Janeiro: FGV Editora, 2000.

CONSTANT, Benjamin. Curso de política constitucional. Tradução de F. L. de Yturbe. Madri: Taurus, 1968.

2001.

A liberdade dos antigos comparada à liberdade dos modernos. Tenacitas: Lisboa, Paulo: UNESP, 2006.

DALLARI, Dalmo de Abreu. Elementos de teoria geral do Estado. 32. ed. São Paulo: Saraiva, 2013.

. A constituição na vida dos povos: da idade média ao século XXI. São Paulo: Saraiva, 2010.

O poder dos juízes. 3. ed. São Paulo: Saraiva, 2007.

Da atualização do Estado. 1963. 146 f. Tese (Livre-Docência) - Faculdade de Direito da Universidade de São Paulo, São Paulo. 1963.

DANTAS, Ivo. $O$ valor da constituição: do controle de constitucionalidade como garantia de supralegalidade constitucional. 2. ed. Rio de Janeiro: Renovar, 2001.

DANTAS, Miguel Calmon. Constitucionalismo dirigente e pós-modernidade. São Paulo: Saraiva, 2010.

DÍAZ, Elías. Estado de derecho y sociedad democrática. Madrid: Taurus, 1998.

DWORKIN, Ronald. Freedom's law: the moral reading of the American Constitution. Cambridge: Harvard University Press, 1996.

ELY, John Hart. Democracy and distrust: a theory of judicial review. 11. ed. Cambridge: Harvard University Press, 2002. 
FAUSTO, Boris. História do Brasil. 12. ed. São Paulo: EDUSP, 2006.

FERRAZ, Anna Cândida da Cunha. Conflito entre Poderes: o Poder Congressual de sustar atos normativos do Poder Executivo. São Paulo: Revista dos Tribunais, 1994.

FERRAZ JUNIOR. Tercio Sampaio. O Judiciário diante da divisão de poderes: um princípio em decadência? In: Direito Constitucional: liberdade de fumar, privacidade, estado, direitos humanos e outros temas. Barueri: Manole, 2007, p. 398-411.

Modelo de Estado e o Estado Democrático de Direito na Constituição. In:

Direito Constitucional: liberdade de fumar, privacidade, estado, direitos humanos e outros temas. Barueri: Manole, 2007, p. 430-445.

FERREIRA FILHO, Manoel Gonçalves. Do processo legislativo. 7. ed. São Paulo: Saraiva, 2012.

A democracia no limiar do século XXI. São Paulo: Saraiva, 2001.

Curso de Direito Constitucional. 39. ed. São Paulo: Saraiva, 2013.

Estado de direito e constituição. 4. ed. São Paulo: Saraiva, 2007.

FIGUEIREDO, Argelina e LIMONGI, Fernando. Executivo e Legislativo na Nova Ordem Constitucional. Rio de Janeiro: Editora FGV, 1999.

FRISCHEISEN, Luiza Cristina Fonseca. Construção da igualdade e o sistema de justiça no Brasil: alguns caminhos e possibilidades. 2004. 139p. Tese (Doutorado em Filosofia e Teoria Geral do Direito) - Faculdade de Direito, Universidade de São Paulo, São Paulo, 2004.

GADAMER, Hans-Georg. Verdade e método. Tradução de Flávio Paulo Meurer. Petrópolis: Vozes, 1997.

HABERMAS, Jürgen. Democracia e Direito: entre facticidade e validade. v. I. Tradução de Flávio Beno Siebeneichler. Rio de Janeiro: Tempo Brasileiro, 2003.

HAMILTON, Alexander; MADISON, James; JAY, John. O federalista. São Paulo: Victor Civita Editor, 1979. (Os Pensadores) 
HESSE, Konrad. A força normativa da constituição. Traduzido por Gilmar Ferreira Mendes. In: Temas fundamentais de direito constitucional. Textos selecionados e traduzidos por Carlos dos Santos Almeida, Gilmar Ferreira Mendes e Inocêncio Mártires Coelho. São Paulo: Saraiva, 2009.

HIRSCHL, Ran. Towards juristocracy: the origins and consequences of the new constitucionalism. Cambridge and London: Harvard University Press, 2004.

HOBSBAWM, Eric. A Era dos Extremos: o breve século XX. Tradução de Marcos Santarrita. 2. ed. São Paulo: Companhia das Letras, 1995.

JELLINEK, Georg. Teoría general del estado. Tradução e prólogo de Fernando Reis de los Ríos. México: Fondo de Cultura Económica, 2000. (Sección de Obras de Política y Derecho)

KELSEN, Hans. A teoria pura do direito. 8. ed. São Paulo: Martins Fontes, 2009. Jurisdição constitucional. 3. ed. São Paulo: Martins Fontes, 2013.

LEAL, Saul Tourinho. Ativismo ou altivez? O outro lado do Supremo Tribunal Federal. Belo Horizonte: Fórum, 2010.

LEWANDOWSKI, Enrique Ricardo. O protagonismo do Poder Judiciário na era dos direitos. Revista de Direito Administrativo, n. 251, p. 77-85, maio/ago. 2009.

Breves considerações sobre a reforma política em discussão no Congresso Nacional. In: CAGGIANO, Monica Herman Salem (Coord.); MESSA, Ana Flávia; ALMEIDA, Fernando Dias Menezes de. (Org.) Direito eleitoral em debate: estudos em homenagem a Cláudio Lembo. São Paulo: Saraiva, 2013. p. 419-426.

LIMA, Francisco Gerson Marques de. O Supremo Tribunal Federal na crise institucional brasileira. Estudo de casos: abordagem interdisciplinar de sociologia constitucional. São Paulo: Malheiros, 2009.

LOCKE, John. Segundo tratado sobre o governo. Tradução de E. Jaci Monteiro. São Paulo: Ibrasa, 1963. 
LOEWENSTEIN, Karl. Teoría de la Constitución. 2. ed. Tradução de Alfredo Gallego Anabitarte. Barcelona: Ariel, 1976.

LOPES, José Reinaldo de Lima. Crise da norma jurídica e reforma do Judiciário. In: FARIA, José Eduardo (Org.). Os direitos humanos, direitos sociais e justiça. São Paulo: Malheiros, 2002. p. 68-93.

LUCARELLI, Alberto. Teorie del presidenzialismo: fondamento e modelli. Verona: Cedam, 2000.

MACIEL, Débora Alves; KOERNER, Andrei. Sentidos da judicialização da política: duas análises. Lua Nova: Revista de Cultura e Política. São Paulo, v. 57, 2002.

MALBERG, Raymond Carré de. Teoría general del Estado. Traducción de José Lión Depetre. México: Fondo de Cultura Económica, 1948.

MAQUIAVELLI, Niccolò. $O$ príncipe: com as notas de Napoleão Bonaparte. 5 ed. Tradução de José Cretella Junior e Agnes Cretella. São Paulo: Revista dos Tribunais, 2009.

MARSHALL, William P. Conservatives and the seven sins of judicial activism. University of Colorado Law Review, v. 73, Sep. 2002. Disponível em: http://ssrn.com/abstract=330266.

MEIRELLES TEIXEIRA, José Horácio. Curso de direito constitucional. Atualizado por Maria Garcia. 2. ed. São Paulo: Conceito, 2011.

MENDES, Gilmar Ferreira; MARTINS, Ives Gandra da Silva. Controle concentrado de constitucionalidade: comentários à Lei n. 9.868, de 10-11-1999. 3. ed. Saraiva: São Paulo, 2009.

; BRANCO, Paulo Gustavo Gonet. Curso de direito constitucional. 8. ed. São Paulo: Saraiva, 2013.

MENDES, Conrado Hübner. Direitos fundamentais, separação de poderes e deliberação. São Paulo: Saraiva, 2011. (Série direito desenvolvimento justiça: produção científica)

MONTESQUIEU, Charles-Louis de Secondat, Barão de la Brède e de. Do espírito das leis. Tradução de Fernando Henrique Cardoso e Leôncio Martins Rodrigues. São Paulo: Abril Cultural, 1979. (Os Pensadores) 
MIRANDA, Jorge. Funções do Estado. Revista de Direito Administrativo, Rio de Janeiro, v. 189, p. 85-99, 1992.

MORAES, Alexandre de. Presidente da República: a força motriz do presidencialismo. 2003. 387 f. Tese (Titularidade) - Faculdade de Direito da Universidade de São Paulo, São Paulo, 2003.

Jurisdição constitucional, constituição e tribunais constitucionais: garantia suprema da constituição. São Paulo: Atlas, 2000.

MORAES, Filomeno. O Poder Legislativo na nova Constituição. Revista da Procuradoria Geral do Estado do Ceará, Fortaleza, n. 7, p. 42-45, 1990.

. As constituintes brasileiras: retrospectiva e tendência. DN Cultura, Fortaleza, n. 156, p. 4-5, 29 set. 1985.

MORAES FILHO, José Filomeno de. Separação de poderes no Brasil pós-88: princípio constitucional e práxis política. In: SOUZA NETO, Cláudio Pereira de; BERCOVICI, Gilberto; MORAES FILHO, José Filomeno de; LIMA, Martonio Mont'Alverne. Teoria da constituição: estudos sobre o lugar da política no direito constitucional. Rio de Janeiro: Lumen Juris, 2003.

MORGADO, Cíntia. A nova face da separação de poderes: capacidades institucionais, vinculação dos poderes e constitucionalismo cooperativo. Revista de Direito Processual Geral, Rio de Janeiro, p. 64-93, n. 66, 2011.

NOVAIS, Jorge Reis. Separação de Poderes e limites da competência legislativa da assembleia da República. Lisboa: Lex, 1997.

OLIVEIRA, Fabiana Luci de. Supremo Tribunal Federal: do autoritarismo à democracia. Rio de Janeiro: Elsevier, FGV, 2012.

PAIXÃO, Leonardo André. Função política do Supremo Tribunal Federal. 2007. 258 p. Tese (Doutorado) - Faculdade de Direito, Universidade de São Paulo, São Paulo, 2007.

PESSANHA, Charles. Relações entre os Poderes Executivo e Legislativo no Brasil: 19461994. 1997. Tese (Doutorado em Ciência Política) - Faculdade de Filosofia, Letras e Ciências Humanas, Universidade de São Paulo, 1997. 
PIÇARRA, Nuno. A separação dos poderes como doutrina e princípio constitucional: um contributo para o estudo das suas origens e evolução. Coimbra: Coimbra Editora, 1989.

PIMENTA BUENO, José Antonio. Direito público brasileiro e análise da Constituição do Império. Brasília: Senado Federal, 1978.

PINTO, Paulo Brossard de Souza. $O$ impeachment: aspectos da responsabilidade política do Presidente da República. 3. ed. São Paulo: Saraiva, 1992.

PONTES DE MIRANDA, Francisco Cavalcanti. Comentários à Constituição da República dos Estados Unidos do Brasil. v. 1. Rio de Janeiro: Guanabara, 1938.

QUEIROZ, Cristina. Os actos políticos no Estado de Direito. Coimbra: Almedina, 1990.

RAMOS, Elival da Silva. Ativismo judicial: parâmetros dogmáticos. São Paulo: Saraiva, 2010.

RANIERI, Nina Beatriz Stocco. Sobre o federalismo e o estado federal. Revista dos Tribunais. Cadernos de direito constitucional e ciência política. Ano 3, n. 9, p. 87-102, out/dez. 2004.

Teoria do Estado: do Estado de Direito ao Estado democrático de Direito. São Paulo: Manolo, 2013.

ROOSEVELT, Franklin Delano. First Inaugural Address of Franklin Delano Roosevelt. Disponível em: http://avalon.law.yale.edu/20th_century/froos1.asp. Acesso em: 08 jul. 2013.

ROUSSEAU, Jean Jacques. Do contrato social. 3. ed. Tradução revista por José Cretella Junior e Agnes Cretella. São Paulo: RT, 2012. (Textos fundamentais).

SALDANHA, Nelson. O estado moderno e a separação de poderes. Saraiva: São Paulo, 1987.

SARMENTO, Daniel. A proteção judicial dos direitos sociais: alguns parâmetros éticojurídicos. In: SOUZA NETO, Cláudio Pereira; __ . (Coord.) Direitos sociais: fundamentos, judicialização e direitos sociais em espécie. Rio de Janeiro: Lumen Iuris, 2008. 
SERRANO, Pedro Etevam Alves Pinto. O desvio de poder na função legislativa. São Paulo: FTD, 1997.

SILVA, José Afonso da. Curso de direito constitucional positivo. 36. ed. São Paulo: Malheiros, 2013. O constitucionalismo brasileiro: evolução institucional. São Paulo: Malheiros, 2011.

SILVA FILHO, Derly Barreto e. Controle dos atos parlamentares pelo Poder Judiciário. São Paulo: Malheiros, 2003.

SIEYÈS, Emmanuel Joseph. A Constituinte Burguesa: Qu'est-ce que le Tiers État?. Organização e Introdução de Aurélio Wander Bastos. Tradução de Norma Azevedo. 4. ed. Rio de Janeiro: Lumen Juris, 2001.

SOUZA JUNIOR, Cezar Saldanha. O tribunal constitucional como poder: uma nova teoria da divisão dos poderes. São Paulo: Memória Jurídica, 2002.

SOUZA NETO, Cláudio Pereira. A justiciabilidade dos direitos sociais: críticas e parâmetros. In: __ _ SARMENTO, Daniel. (Coord.) Direitos sociais: fundamentos, judicialização e direitos sociais em espécie. Rio de Janeiro: Lumen Iuris, 2008, p. 515-551.

STRECK, Lênio Luis. Jurisdição constitucional e hermenêutica: uma nova crítica do Direito. Porto Alegre: Livraria do Advogado, 2002.

A hermenêutica filosófica e a teoria da argumentação da ambiência do debate do 'positivismo (neo) constitucionalismo'. In: Diálogos constitucionais: direito, neoliberalismo e desenvolvimento em países periféricos. Rio de Janeiro: Renovar, 2006.

SUNDFELD, Carlos Ari. Fundamentos de Direito Público. 4. ed. São Paulo: Malheiros, 2006.

SUSTEIN, Carl. Radicals in robes: why extreme right-wing Courts are wrong for America. New York: Basic Books, 2005.

TATE, Neal; VALLINDER, Torbjörn. The global expansion of judicial power. New York: New York University Press, 1995. 
TAVARES, André Ramos. Curso de direito constitucional. 8. ed. São Paulo: Saraiva, 2010. . Paradigmas do judicialismo constitucional. São Paulo: Saraiva, 2012. Manual do Poder Judiciário brasileiro. São Paulo: Saraiva, 2012.

A superação da doutrina tripartite dos Poderes do Estado. Revista dos Tribunais, Cadernos de Direito Constitucional e Ciência Política, São Paulo, v. 29, Out. 1999.

TEIXEIRA, Sálvio de Figueiredo. Compromisso com o direito e a justiça. Belo Horizonte: Del Rey, 2008.

TOCQUEVILLE, Alexis. Democracy in America. Vintage Books, 10. ed., 1961.

TORRES, José Camilo de Oliveira. A democracia coroada. Petrópolis: Vozes, 1964.

TULIS, Jeffrey. Deliberation between institutions. In: LASLETT, Peter; FISHKIN, James (Ed.). Debating deliberative democracy. Malden: Blackwell, 2003.

TUSHNET, Mark. Taking the constitution away from the courts. Princeton: Princeton University Press, 1999.

VERBICARO, Loiane Prado. Um estudo sobre as condições facilitadoras da judicialização da política no Brasil. Revista Direito GV, n. 4, p. 389-406, jul/dez. 2008.

VERÍSSIMO, Marcos Paulo. A Constituição de 1988, vinte anos depois: Suprema Corte e ativismo judicial “à brasileira”. Revista Direito GV, v. 4, ano 2, p. 407-440, jul/dez. 2008.

VIANNA, Luiz Werneck; BURGOS, Marcelo Baumann; Salles, Paula Martins. Dezessete anos de judicialização da política. Tempo Soc., São Paulo, v. 19, n. 2, Nov. 2007. Disponível em: http://www.scielo.br/pdf/ts/v19n2/a02v19n2.pdf.

; CARVALHO, Maria Alice Rezende de; MELO, Manuel Palacios Cunha; BURGOS, Marcelo Baumann. A judicialização da política e das relações sociais no Brasil. Rio de Janeiro: Revan, 1999.

VIANNA, Oliveira. Instituições políticas brasileiras. v. 1. Belo Horizonte: USP/UFF, 1987. 
VIEIRA, José Ribas; CAMARGO, Margarida Maria Lacombe; SILVA, Alexandre Garrido da. O Supremo Tribunal Federal como arquiteto institucional: a judicialização da política e o ativismo judicial. In: Anais do I Fórum de Grupos de Pesquisa em Direito Constitucional e Teoria do Direito. Rio de Janeiro: Faculdade Nacional de Direito, 2009.

WALDRON, Jeremy. Law and disagreement. Oxford: Clarendon Press, 1999.

ZAGREBELSKY, Gustavo. El derecho dúctil: ley, derechos, justicia. Tradução de Marina Gascón. 5. ed. Madrid: Trotta, 2003.

Diritto constituzionale: il sistema delle fonti del diritto. v. 1. 1. ed. Torino: Unione Tipografico-Editrice Torinese, 1998. 